\title{
3. SITE 533: BLAKE OUTER RIDGE ${ }^{1}$
}

\author{
Shipboard Scientific Party ${ }^{2}$
}

\section{HOLE 533}

\begin{abstract}
Date occupied: $13-16$ October 1980
\end{abstract}
Position: $31^{\circ} 15.6^{\prime} \mathrm{N}, 74^{\circ} 52.2^{\prime} \mathrm{W}$

Water depth (sea level; corrected m, echo-sounding): 3191

Bottom felt ( $m$, drill pipe from rig floor): 3194

Penetration (m): 167.6

Number of cores: 41

Total length of cored section (m): 167.6

Total core recovered $(\mathrm{m}): 146$

Core recovery $(\%): 87$

Oldest sediment cored:

Depth sub-bottom (m): 167.6

Nature: Silty clay

Age: Late Pliocene

Basement: Not reached

\section{HOLE 533A}

Date occupied: $16-19$ October 1980

Position: $31^{\circ} 15.6^{\prime} \mathrm{N}, 74^{\circ} 52.2^{\prime} \mathrm{W}$

Water depth (sea level; corrected m, echo-sounding): 3191

Bottom felt (m, drill pipe from rig floor): 3194

Penetration (m): 399

Number of cores: 29

Total length of cored section (m): 259.2

Total core recovered $(\mathrm{m}): 213.5$

Core recovery $(\%): 82$

Oldest sediment cored:

Depth sub-bottom (m): 389.5

Nature: Nannofossil clay

Age: Middle Pliocene

Basement: Not reached

Principal results: A stratigraphically continuous record was obtained of middle Pliocene through Holocene gray green mudstone. The

\footnotetext{
${ }^{1}$ Sheridan, R. E., Gradstein, F. M., et al., Init. Repts. DSDP, 76: Washington (U.S. Govt, Printing Office).

2 Robert Sheridan (Co-Chief Scientist), Department of Geology, University of Delaware, Newark, Delaware; Felix Gradstein (Co-Chief Scientist), Bedford Institute of Oceanography, Geological Survey of Canada, Dartmouth, Nova Scotia, Canada; Leo A. Barnard, Department of Oceanography, Texas A\&M University, College Station, Texas; Deborah M. Bliefnick, Earth Sciences Department, University of California, Santa Cruz, California; Daniel Habib, Department of Earth and Environmental Sciences, Queens College, Flushing, New York; Peter D. Jenden, Institute of Geophysics and Planetary Physics, University of California, Los Angeles, California; Hideo Kagami, Ocean Research Institute, University of Tokyo, Nakano, Tokyo, Japan; Everly M. Keenan, Department of Geology, University of Delaware, Newark, Delaware; John Kostecki, Lamont-Doherty Geological ObServatory, Columbia University, Palisades, New York; Keith Kvenvolden, U.S. Geological Survey, Menlo Park, Califory, Michel Moullade, Centre de Rechereses MicropaleonicaloSurvey, Menlo Park, California, Michel Moullade, Centre de Recherches Micropaleontologiques, Université de Nice, Nice, France; James Ogg, Geological Research Division, Scripps Institution of Oceanography, La Jolla, California; Peter H. Roth, Department of Geology and Geophysics, University of Utah, Salt Lake City, Utah; Thomas Shipley, Deep Sea Drilling Project, Scripps Institution of Oceanography, La Jolla, California (present address: University of Texas, Institute of Geophysics, Austin, Texas).
}

pre-Quaternary deposits have virtually no visible stratification. The rate of deposition decreases over $50 \%$ from the Pliocene into the Pleistocene varying from $17 \mathrm{~cm} / 1000 \mathrm{yr}$. in the Pliocene to 8 $\mathrm{cm} / 1000 \mathrm{yr}$. in the Pleistocene. A local unconformity on the seismic record separates Pliocene from Pleistocene beds at $158 \mathrm{~m}$ subbottom and probably is an erosional event shaped by contour-following currents. The alkalinity shows a strong negative gradient across the local unconformity, suggesting diffusion control by closure. Patchy stratification on the seismic record in the Pliocene interval may be due to "concretions" of calcitic mudstone and thin gas-hydrate lenses. No explanation was found for the apparent acoustic transparency of the Pliocene section as seen on seismic profiles. The temperature gradient varies from $5.1^{\circ} \mathrm{C} / 100$ $\mathrm{m}$ near the seafloor to $3.6^{\circ} \mathrm{C} / 100 \mathrm{~m}$ at the bottom of the hole, which agrees with the prediction that the strong bottom-simulating reflector at $0.60 \mathrm{~s}$ is the result of hydrate inversion. Two sonobuoy profiles confirm a velocity inversion at this depth. Outgassing of mudstone cores increased downhole, and a few thin beds $(3-5 \mathrm{~cm})$ of gas hydrate were sampled at $240 \mathrm{~m}$. The hydrate sample expanded 13 times its total volume ( 20 times its pore-space volume) upon decomposition, yielding mainly methane and significant concentrations of propane and isobutane. Normal butane and higher molecular weight gases were in low concentrations as expected, because these molecules are too large to be included in the gas-hydrate structure. The pressure core barrel (PCB) was deployed successfully four times, and geochemical analyses of gases from this tool showed the presence of hydrocarbon gases with decreasing $\mathrm{C}_{1} / \mathrm{C}_{2}$ ratios with depth toward the bottom of the hole. Initial analyses of the pressure-release experiment from the PCB yielded indirect evidence of gas hydrates in the sampled intervals, however, these experiments could not quantify the amounts of hydrates in the hydrated sediments. The only positively observed hydrates were in thin $(<10 \mathrm{~cm})$ layers.

\section{BACKGROUND AND OBJECTIVES}

The Blake Outer Ridge is an unusual topographic feature extending southeast as a spitlike extension of the continental rise sedimentary prism (Fig. 1). Extensive studies of the Ridge have been carried out in the past, including seismic refraction surveys (Hersey et al., 1959), single-channel seismic reflection surveys (Markl et al., 1970 ), piston coring and photographic studies (Heezen et al., 1966; Sheridan et al., 1974), deep-sea drilling studies (Ewing and Hollister, 1972), and, most recently, multichannel seismic reflection profiling (Shipley et al., 1978; G. M. Bryan and R. G. Markl, personal communication 1982). From these studies we know that the Blake Outer Ridge formed by the complex accretion of hemipelagic muds controlled in some way by contourfollowing currents (Heezen et al., 1966). On the basis of drilling at DSDP Sites 102, 103, and 104 (Hollister, Ewing, et al., 1972a), we believe that sedimentation rates are relatively rapid in the area $(5-15 \mathrm{~cm} / 1000$ yrs.).

A fundamental phenomenon discovered on Leg 11 at Sites 102, 103, and 104 is that reflector Y of Markl et al. (1970) is actually a time transgressive, bottom-simulating reflector (BSR) (Fig. 2). Obviously secondary diagenetic processes caused a physical change (increase or 


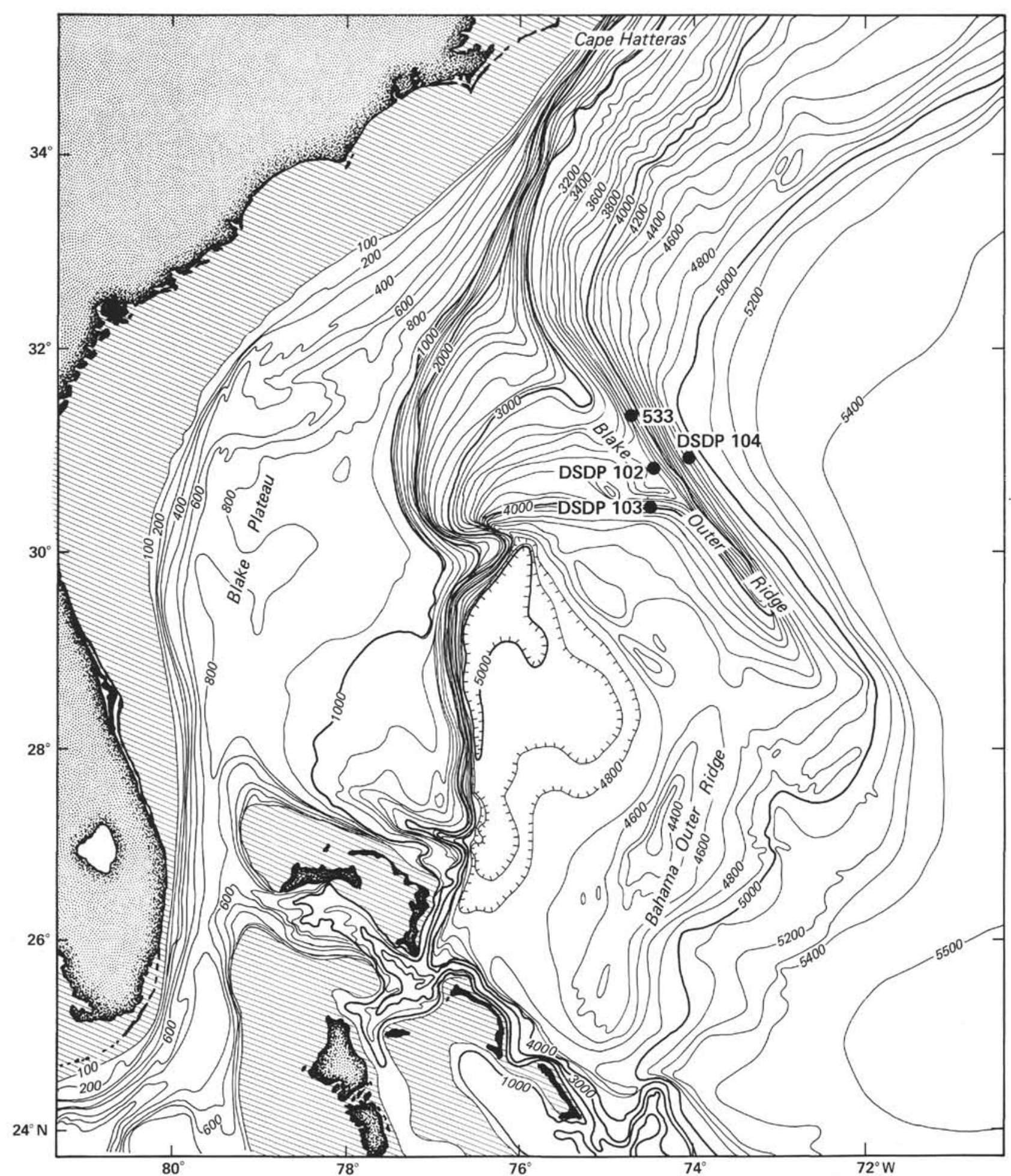

Figure 1. Topography of the Blake and Bahama outer ridges (Uchupi, 1968). (Site 533 is located on the crest of the Blake Outer Ridge.)

decrease in acoustic impedance) to be overprinted on the depositional stratigraphy. One possible explanation for this BSR phenomenon is the presence of solid gas hydrates in the uppermost sediments. According to this model, solid gas hydrate, which is present below the seafloor, changes to a fluid-gas phase below a phase-change boundary at the BSR. The sub-bottom depth of the phase change is controlled by pressure and temperature and therefore varies with ocean water depth (Fig. 2). For a review of the geologic occurrence of gas hydrates, see Kvenvolden and McMenamin (1980).

After this initial discovery of the possible existence of gas hydrates under the Blake Outer Ridge, more highquality seismic reflection surveys were conducted in the area (G. M. Bryan and R. G. Markl, personal communication 1982; Shipley et al., 1978; Paul and Dillon et al., 


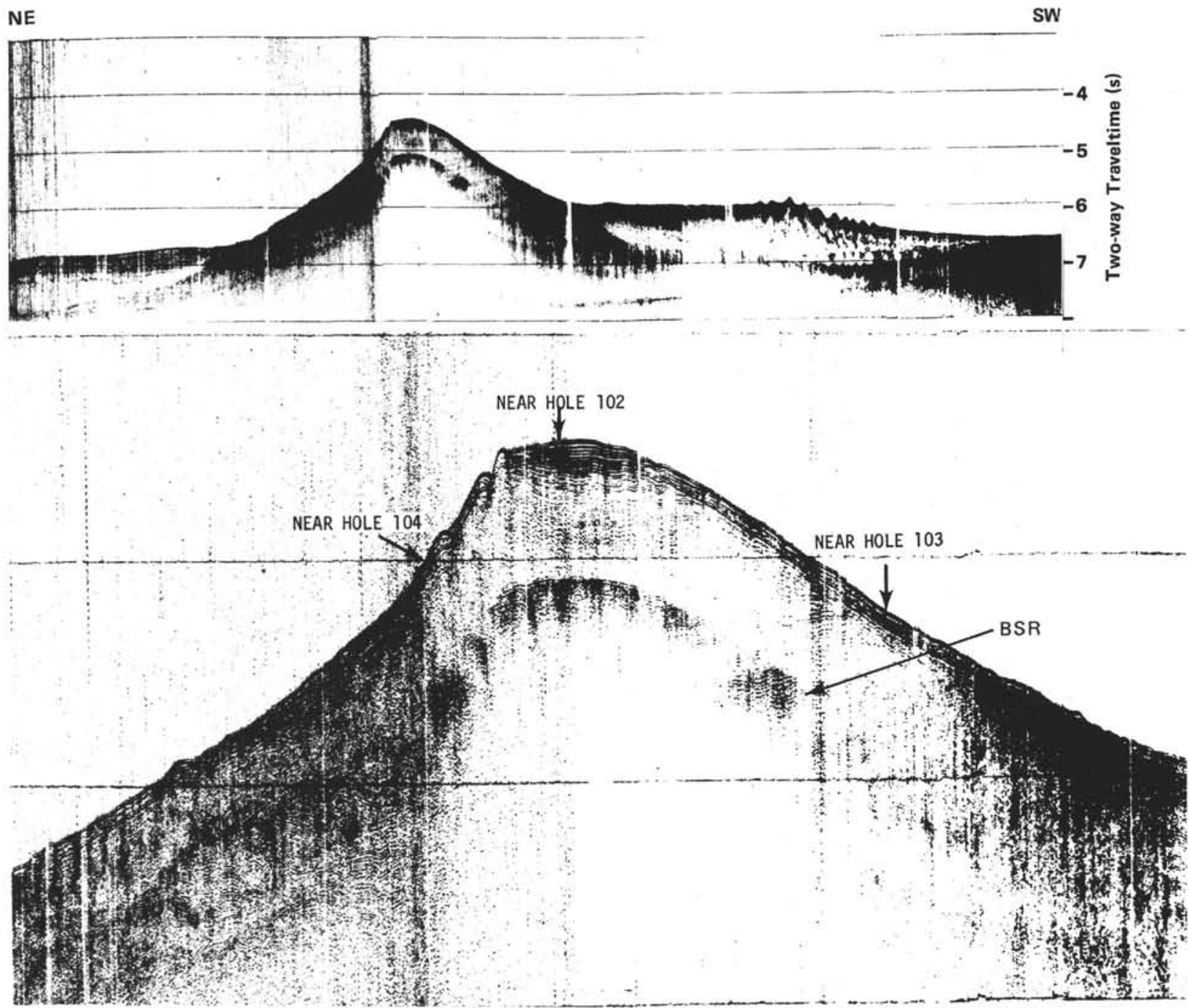

Figure 2. Single-channel seismic-reflection profile across the Blake Outer Ridge (from Hollister, Ewing, et al., 1972b). (The BSR is identical to reflector Y identified by Markl et al. [1970].)

1981) (Fig. 3). These surveys revealed acoustic phenomena that have characteristics commonly associated with gas hydrates. Moreover, seismic studies in other areas indicate the presence of similar acoustic features that are suspected to be gas hydrates; thus the occurrence of such features as BSRs is not unique to the Blake Outer Ridge (Shipley et al., 1979).

Some acoustic observations on the Blake Outer Ridge that support the hypothesis that gas hydrates are present are listed as follows:

1) Evidence of relatively high compressional-wave seismic velocities $(2.0-2.5 \mathrm{~km} / \mathrm{s})$ between the BSR and seafloor (Hollister, Ewing, et al., 1972a; Dillon et al., 1980; Shipley et al., 1979).

2) Evidence of a change of the reflection wavelet polarity at the BSR, indicating the presence of an inversion in acoustic impedance (Shipley et al., 1979) (Fig. 4).

3) Evidence of acoustic transparency between the BSR and the seafloor, perhaps the result of a stiffening caused by the ice as well as a loss of bedding impedance contrasts (Fig. 5).
4) Variation in sub-bottom depth of the BSR with water depth in a manner similar to that predicted for a hydrate phase-change boundary (Tucholke et al., 1977) (Fig. 6).

5) Evidence for the thermal disturbance of the BSR in areas around possible salt domes, which refract the heat flow and cause the geotherms to rise at their crest (Dillon et al., 1980) (Fig. 7).

This excellent acoustic data on the Blake Outer Ridge strongly indicates the presence of gas hydrates. The acoustic evidence is supported by theoretical considerations of gas-hydrate stability fields (Fig. 8) and by preliminary geochemical observations made on Leg 11 (Lancelot and Ewing, 1972). The phase-boundary diagram (Fig. 8) shows that gas hydrates should be stable given the pressure and temperature conditions of the sediments in the area of the Blake Outer Ridge. Lancelot and Ewing (1972) noted the presence of large amounts of gas in the sediments of the entire sequence sampled at Sites 102, 103,104 , and 106 of Leg 11 . In many cases, gas expansion caused extrusion of sediment from core liners. Cores 


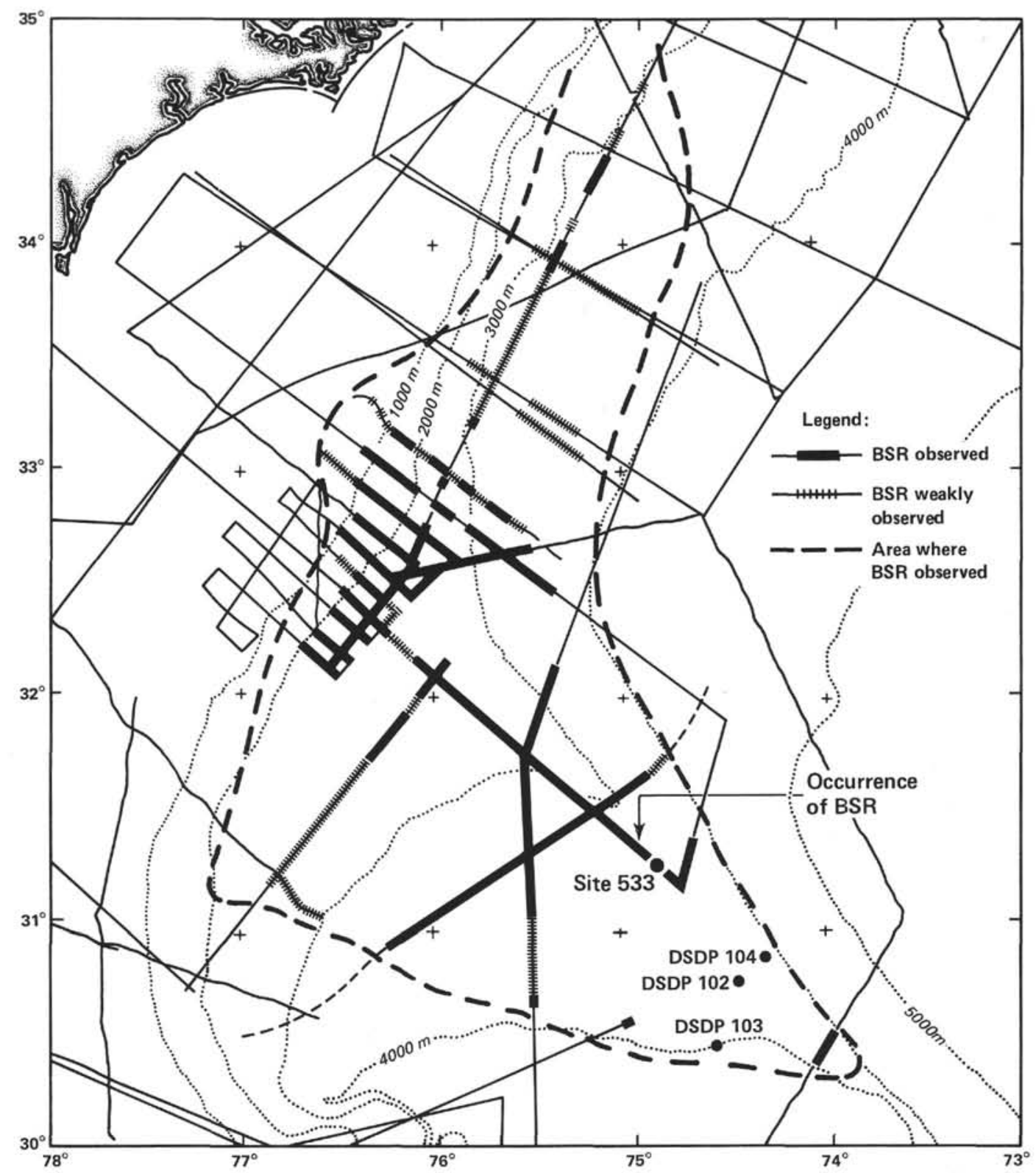

Figure 3. Map showing the occurrence and distribution of the BSR (bottom-simulating reflector) on the Blake Outer Ridge (from Paull and Dillon, 1979).

continued to produce gas for 1 to $2 \mathrm{hr}$.; the gas was composed dominantly of methane, carbon dioxide, and traces of ethane. No solid gas hydrate was noted. These geochemical observations, although supportive of the presence of gas hydrates, do not unequivocally signal their occurrence. High concentrations of gas leading to gas expansion of sediments in core liners are common at many sites drilled by the Deep Sea Drilling Project (see reviews by Claypool et al. [1973]; and McIver [1974]). Frozen gaseous sediments, presumed to be gas hydrates, have been recovered on Legs 66 and 67 on the slope of the Middle America Trench off Central America (Scientific Party, Leg 66, 1979; Scientific Party, Leg 68, 1979). On both of these legs, gas-releasing cores were observed. Frozen sediment was recovered from the zone of gas-hydrate stability at Sites 490, 491, 492, 497, and 498. Gas expansion volumes as high as 50 to 1 suggest that gas hydrates had indeed been sampled.

Because of the detailed acoustic data and the preliminary geochemical observations, the Blake Outer Ridge provides a unique opportunity to test convincingly, for the first time, the hypothesis that gas hydrates are present under the oceans. Such a test requires appropriate pressure-testing devices like the pressure core barrel (Fig. 9) (Larson et al., 1980) in order to establish pressure decline characteristics attributable to gas hydrates (Fig. 10). Analyses of gases recovered from the pressure devices yielded molecular and isotopic compositions 


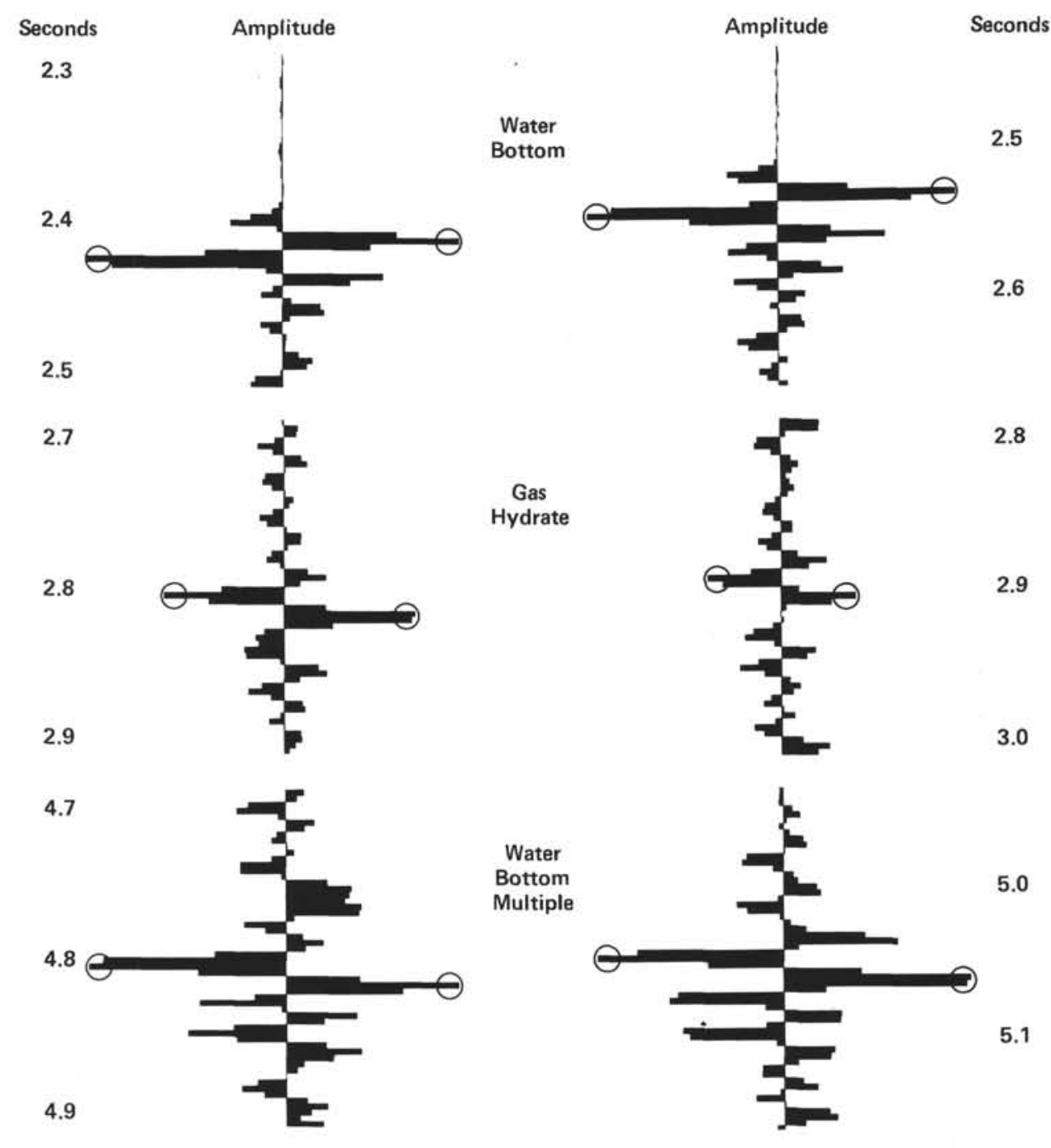

Figure 4. Display of digital recordings of two seismic reflection traces from the Blake Outer Ridge showing the phase reversal at the lower boundary of the gas hydrate (from Shipley et al., 1979).

SW

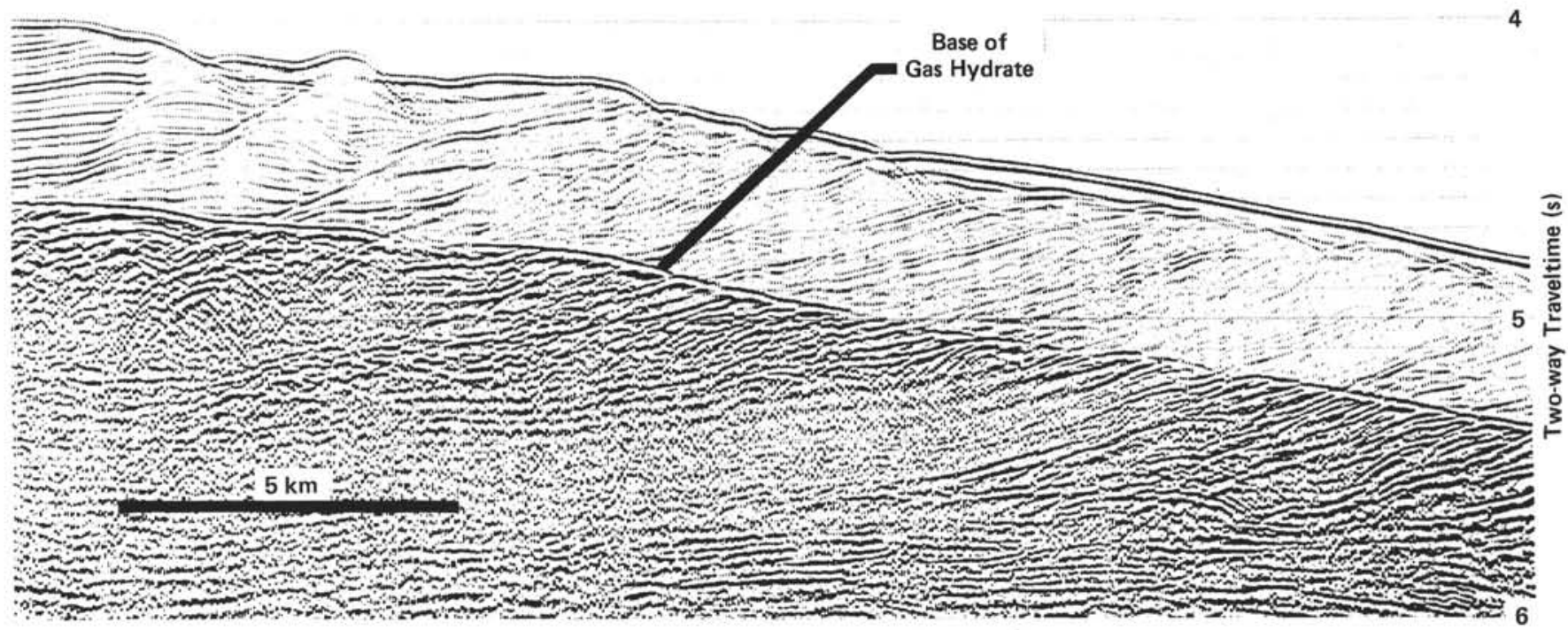

Figure 5. Multichannel seismic reflection profile from the Blake Outer Ridge showing the BSR at the base of the gas hydrate. (Note the apparent acoustic transparency of the gas-hydrate layer [from Shipley et al., 1979].) 


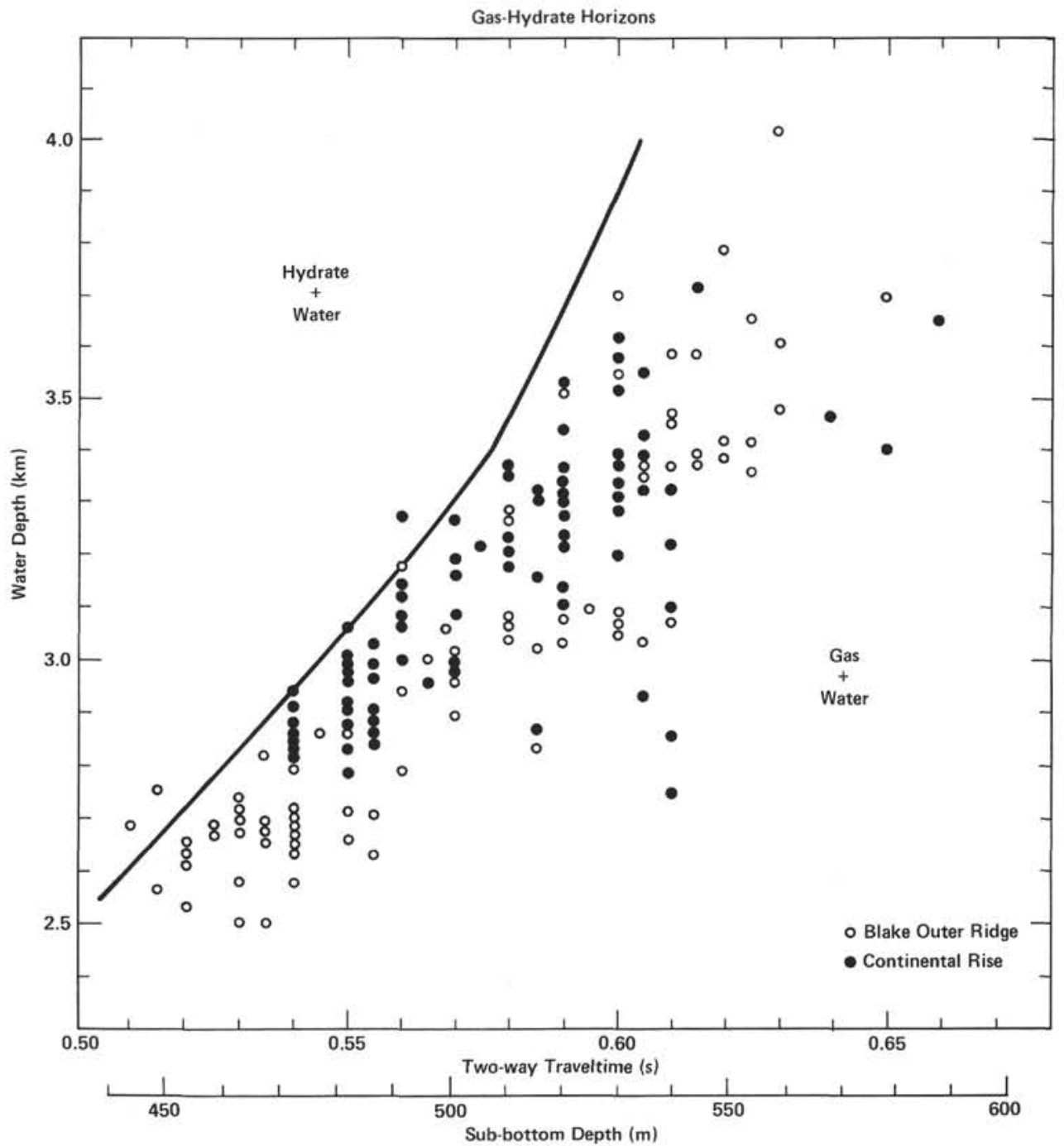

Figure 6. Plot of depth of the BSR below the seafloor versus water depth. (Also shown is the theoretical phase boundary between hydrate and gas in solution. From Tucholke et al. [1977])

from which interpretations could be made regarding sources of gases and processes involved in gas-hydrate formation.

The exact location of Site 533 was selected on multichannel line MC-87, recorded by the Robert D. Conrad on Cruise 2102 (Fig. 11); these data were supplied by G. Bryan and R. Markl of Lamont-Doherty Geological Observatory (Bryan and Markl, personal communication 1982). At the site the BSR is very well developed, as are many of the other acoustic characteristics. Above the BSR at least three lithologic units in the Blake Ridge Formation are seismically identified. If some lithologic variations are present above the BSR, correlation of the hydrate occurrence with various porosities, permeabilities, and lithologies can be made.

The main objectives at Site 533 were:

1) To sample the gas hydrates with a pressure core barrel for quantitative tests of the gas pressures and volumes.

2) To sample the gas itself for compositional analyses, which can distinguish biogenic versus thermogenic origin (and therefore possible depth of source).
3) To sample and preserve under pressure natural samples of the gas hydrate.

4) To photograph and observe the gas hydrate before decomposition.

5) To obtain complete mechanical logs in order to measure the in situ physical properties (these logs would be analyzed in comparison with available seismic data in the area and directly at the site).

6) To study the primary sedimentary structures in the cores in order to understand better the complex deposition of contourites and accretion of the Blake Outer Ridge.

\section{OPERATIONS}

After several days of testing the equipment on the Glomar Challenger, we left Norfolk, Virginia, U.S.A. to begin Leg 76 on 11 October 1980, at $0610 \mathrm{hr}$. (local time). Transit speed was at first impeded by head winds, the crossing of the Gulf stream, and by reduced speed because of adjustments being made to overhauled machinery; however, during the last half day we averaged a speed of 10.3 knots. Just after midnight on 13 October 


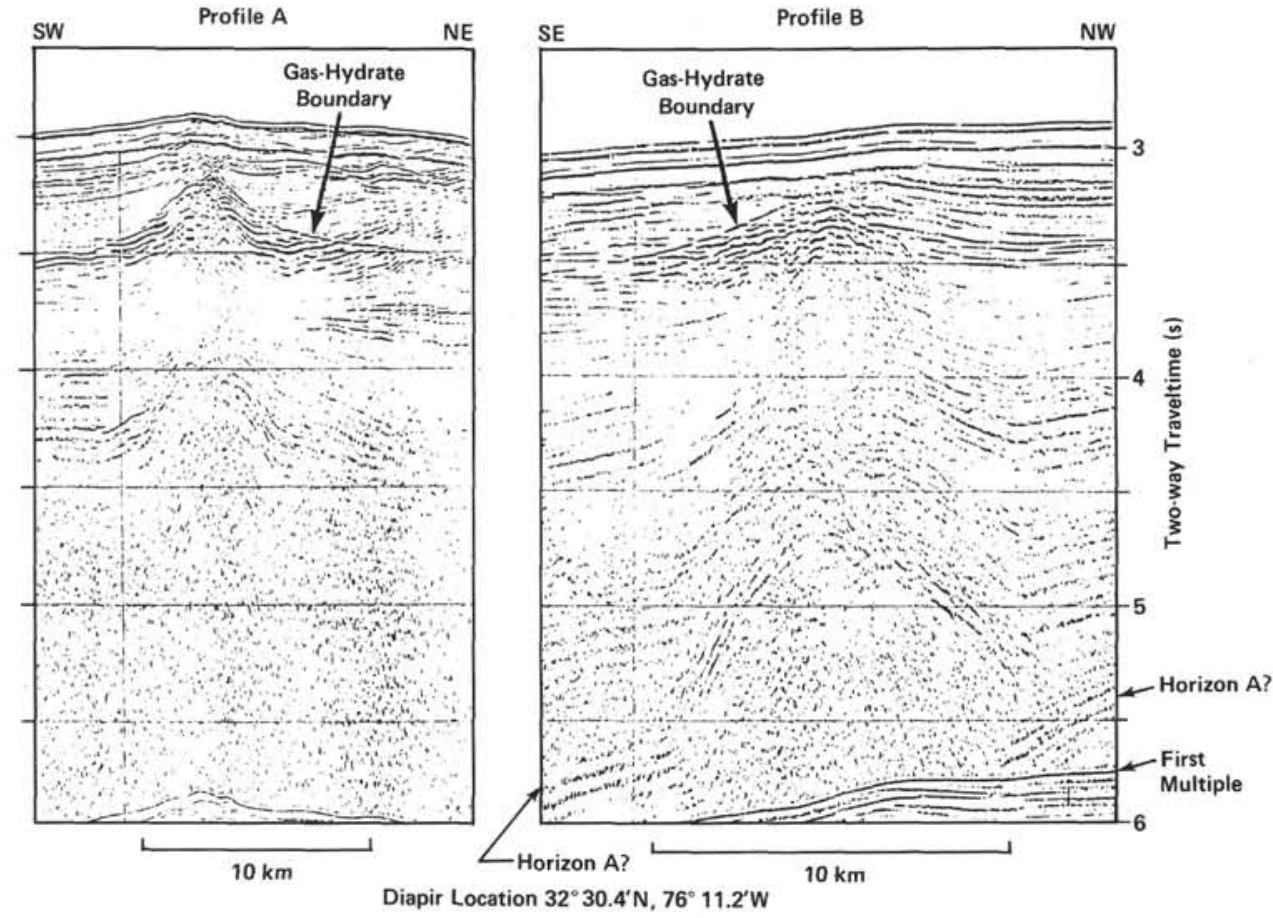

Figure 7. Seismic reflection profiles across suspected salt diapir that may have caused a thermal disturbance of the gas-hydrate boundary (from Dillon et al., 1980).

1980, we arrived at Point A (Fig. 12), immediately south of seismic line MC-87, and slowed down to 6 knots. We then attempted to reoccupy the MC-87 line and run a similar course, but because of poor Loran $\mathrm{C}$ reception at night and lack of adjustments to the satellite antenna, our track was 2 nautical miles (n. mi.) south of the apparent position of the MC-87 line. We followed the direction of the MC-87 seismic line proceeding southeast, and at around $0145 \mathrm{hr}$. (local time) we arrived on the Blake Outer Ridge crest with the bottom-simulating reflector (BSR) clearly visible on Challenger's reflection profile (Fig. 13). At $0222 \mathrm{hr}$. the first of two $73-\mathrm{MHz}$ Ref Tek sonobuoys was launched (Point B on Fig. 12). While shooting away from Sonobuoy 1, the position of Site 533 at $31^{\circ} 15.6^{\prime} \mathrm{N}$ and $74^{\circ} 52.19^{\prime} \mathrm{W}$ was reached (at $0240 \mathrm{hr}$.). The ship's reflection profile showed an excellent match with the drilling target (as selected on the Conrad MC-87 multichannel record), and at that spot a $16-\mathrm{kHz}$ beacon was dropped. We proceeded until 0324 hr. on a course of $130^{\circ}$ and then turned to a southwest-westerly course to reach Point D. A temporary discrepancy between electronic positioning and dead reckoning created uncertainty as to the new course to steer at Point $\mathrm{D}$ in order to return to the beacon.

At $0528 \mathrm{hr}$. a slight course correction was made from $047^{\circ}$ to $055^{\circ}$, and at $0620 \mathrm{hr}$. contact was reestablished with the beacon. While passing again over the beacon at $0646 \mathrm{hr}$., a second sonobuoy was launched and recording was finished at Point E, $12 \mathrm{~km}$ northeast of the beacon. The Challenger then returned to the Site at 0948 hr., 13 October 1980 , and the ship was positioned automatically with four hydrophones lowered.
A surprisingly strong current (1.5 knots) was noted from the north-northwest. Once the stable dynamic position mode had been achieved at $1000 \mathrm{hr}$., the pipe was run in the hole. The first trip was interrupted for a total of 3 and $1 / 4 \mathrm{hr}$. for repairs to the drawworks auxiliary electrical brake and to the piperacker skate cable. The pinger assembled at $400 \mathrm{~m}$ above the bit recorded a water depth (below the rig floor) of $3194 \mathrm{~m}$, compared to the precision depth sounder of $3201 \mathrm{~m}$ (corrected to the rig floor). Because we did not want to miss the mudline, the first hydraulic piston core (HPC) was shot at $2 \mathrm{~m}$ above pinger mudline depth; the time was $2345 \mathrm{hr}$. on 13 October 1980. The first core was retrieved at $0024 \mathrm{hr} .14$ October 1980, with 2.7 out of $4.5 \mathrm{~m}$ recovery. A likely Holocene dating of the sediment also confirmed the pinger mudline depth. After that, coring continued more or less smoothly, and a total of 41 hydraulic piston cores with an average of $87 \%$ recovery were retrieved to a subbottom depth of $167.6 \mathrm{~m}$ (Table 1). The degree of compaction of the sediments at this depth was approaching the limits $\left(1900 \mathrm{~g} / \mathrm{cm}^{2}\right.$ and 3 shear pins in the core assembly) of penetrating ability when the decision was made to terminate piston coring and proceed with rotary-coring operations. The only coring malfunctions were that (1) the piston rod in the inner core barrel became unscrewed once, (2) rust in the pipe and new seals on the piston that were too large for the liners prevented full stroke, (3) the plastic core liner stuck in the core barrel twice and had to be retrieved forcefully, to the detriment of the cored sediment, and (4) about $20 \%$ of the plastic liners were fractured. The liner damage presumably was due in part to suction-induced implosion when 


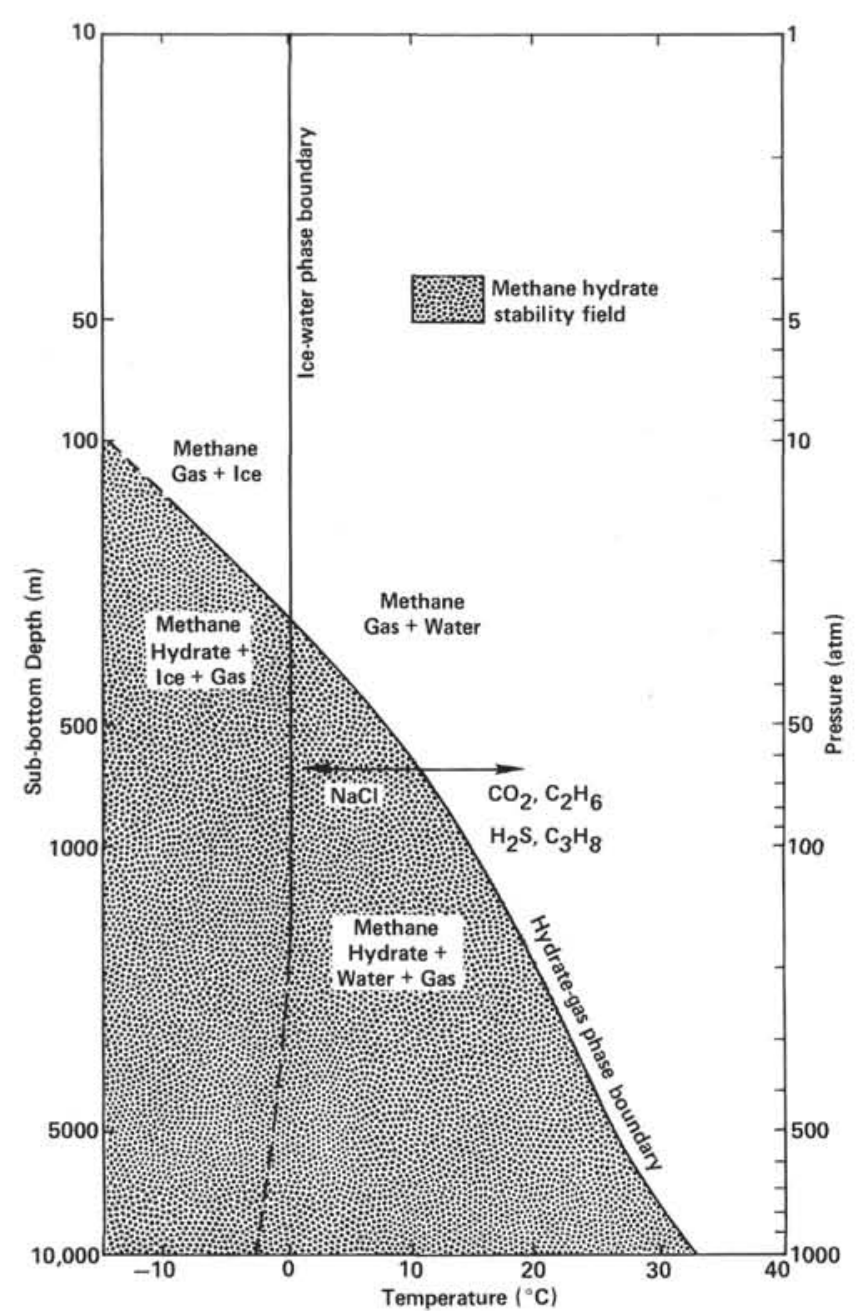

Figure 8. Phase-boundary diagram showing free methane gas and methane hydrate for a fresh water-pure methane system. (Addition of $\mathrm{NaCl}$ to water lowers the temperature of hydrate formation, in effect shifting the gas-hydrate curve to the left. Addition of $\mathrm{CO}_{2}, \mathrm{H}_{2} \mathrm{~S}, \mathrm{C}_{2} \mathrm{H}_{6}$, or $\mathrm{C}_{3} \mathrm{H}_{8}$ raises the temperature of hydrate formation, in effect shifting the curve to the right. Therefore, impurities in natural gas will increase the area of the hydrate stability field. Depth scale is an approximation, assuming that lithostatic and hydrostatic pressure gradients are both 0.1 atmosphere per meter $[10.1 \mathrm{kPa} / \mathrm{m}]$, but the true lithostatic gradient is slightly greater. After Katz et al. [1959] and Kvenvolden and McMenamin [1980].)

the core was pulled out of its stratigraphic position. Relative orientation from core to core for the piston corer was achieved in almost all cases $(90 \%)$, except when major liner failure took place or where no shot marks appeared on the aluminum orientation ring.

Upon completion of drilling, Hole 533 was filled with mud and the drill string was recovered; the bit arrived on deck at $0600 \mathrm{hr} ., 16$ October.

Hole 533A was spudded in at $1725 \mathrm{hr}$. on 16 October; the location was not offset from Hole 533. A pressure core barrel (PCB) bit complemented the assembly. We drilled down to $142.5 \mathrm{~m}$ and on the way down took two (wash) cores, a heat-flow measurement, and a porewater sample. At this depth, the heat-flow-pore-water sampler malfunctioned, but deeper down in the hole

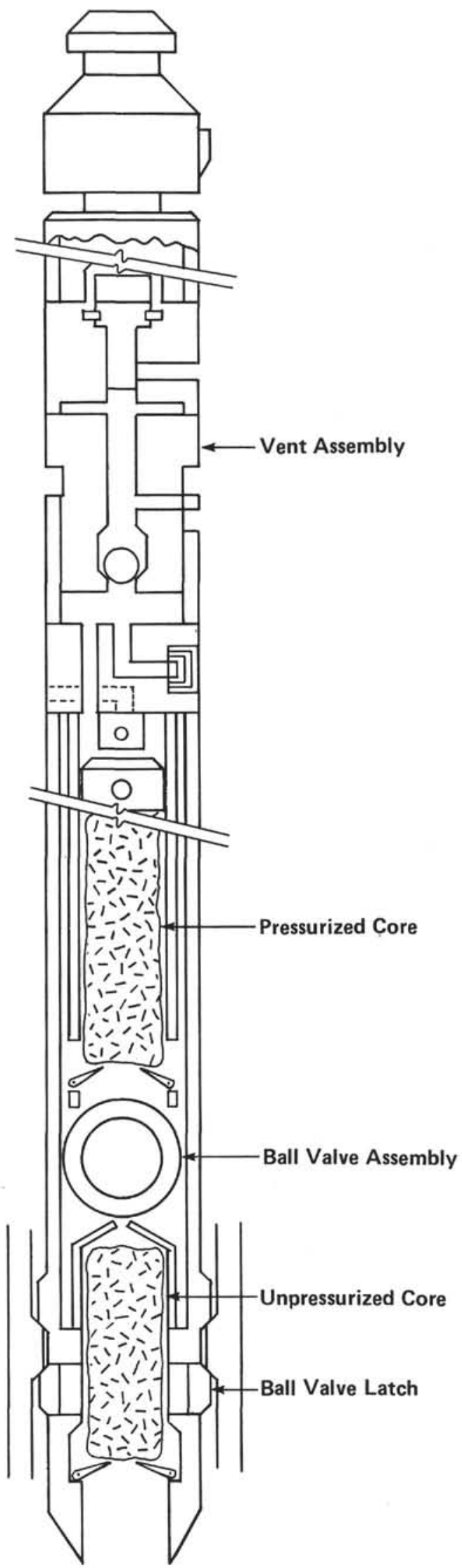

Figure 9. Engineering diagram of pressure core barrel (PCB) (from Larson et al., 1980). 


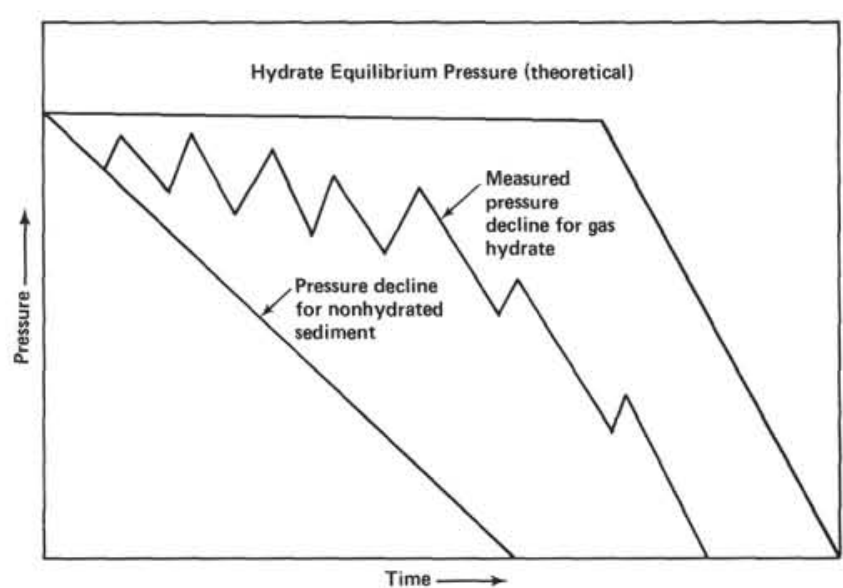

Figure 10. Hypothetical pressure release curve for hydrate sediments (from Hunt, 1979).

three good temperatures were obtained. In Hole 533A at $142.5 \mathrm{~m}$ a particularly strong outgassing of the clay had been observed, indicative of potential hydrate. Accordingly, we employed the PCB at this depth and successfully recovered four sections of sediment under 4500 PSI. The heat-flow probe also gave good results, but the pore-water sampler failed to recover fluids, as it failed to do on two later attempts. Regular coring resumed and continued during 17 October. At this time, poor weather reduced the stability of the vessel, which slowed down the operations. Station keeping was difficult. Most of the cores continued to show much outgassing, and at $2215 \mathrm{hr}$., Core 13, recovered from 237.5 to 247.0 $\mathrm{m}$ sub-bottom, showed gas hydrate in Section 1. We immediately employed the $\mathrm{PCB}$ to core the directly under- lying sediment, but the instrument was not properly prepared and failed to seal. On the basis of the appearance of the core, it was felt that rotary Core 12 also may have encountered some hydrate, but only mudstone slurry was recovered. During the day of 18 October and the night of 19 October, the seas abated and good progress was made with coring. The PCB was employed successfully three more times in zones with strong indications of gas, but no further hydrate was recovered as visibly outgassing sediments. Coring was discontinued at $399 \mathrm{~m}$ at the limit set by safety requirements. No mechanical logging of the hole was achieved, because of stubborn bit-release latches and jamming of the go-devil bit-release tool. At $1900 \mathrm{hr}$. we decided to pull pipe and abandon the Site. All tools arrived on deck at $2315 \mathrm{hr} ., 19$ October, and the Challenger got underway for Site 534 at $2354 \mathrm{hr}$.

\section{LITHOLOGY}

At Site 533, two holes (533 and 533A) were drilled on the east flank of the crest of the Blake Outer Ridge in water depths of $3191 \mathrm{~m}$. At Hole 533, a total of $167.6 \mathrm{~m}$ was cored using the hydraulic piston corer (HPC). The total recovery from this hole was $146 \mathrm{~m}$, composed mostly of interbedded medium to dark greenish gray nannofossil (silty) marls and silty (nannofossil) clays, ranging in age from Holocene to latest Pliocene (Fig. 14). Hole 533A was drilled to a depth of $399 \mathrm{~m}$, with continuous coring between 154.5 and $399.0 \mathrm{~m}$. Five of the 29 cores drilled at Hole 533A were taken with the Pressure Core Barrel (PCB). The aim was to sample gas hydrates in situ. Recovery at Hole 533A was $203.5 \mathrm{~m}$, composed mostly of indurated, dark greenish gray, silty (nannofossil) Pleistocene to middle Pliocene mud.

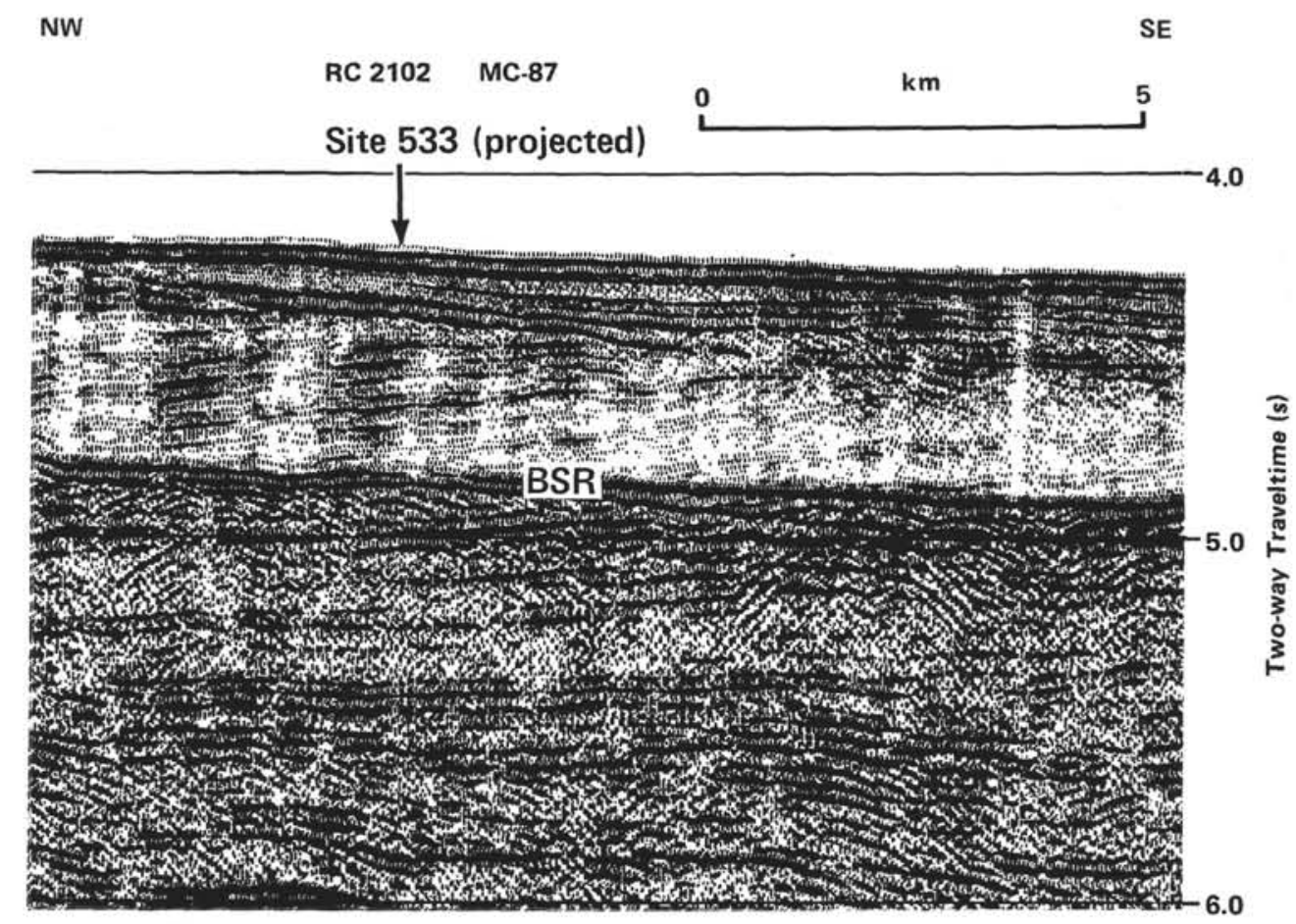

Figure 11. Twenty-four channel, seismic reflection profile made from the Robert Conrad near Site 533. 


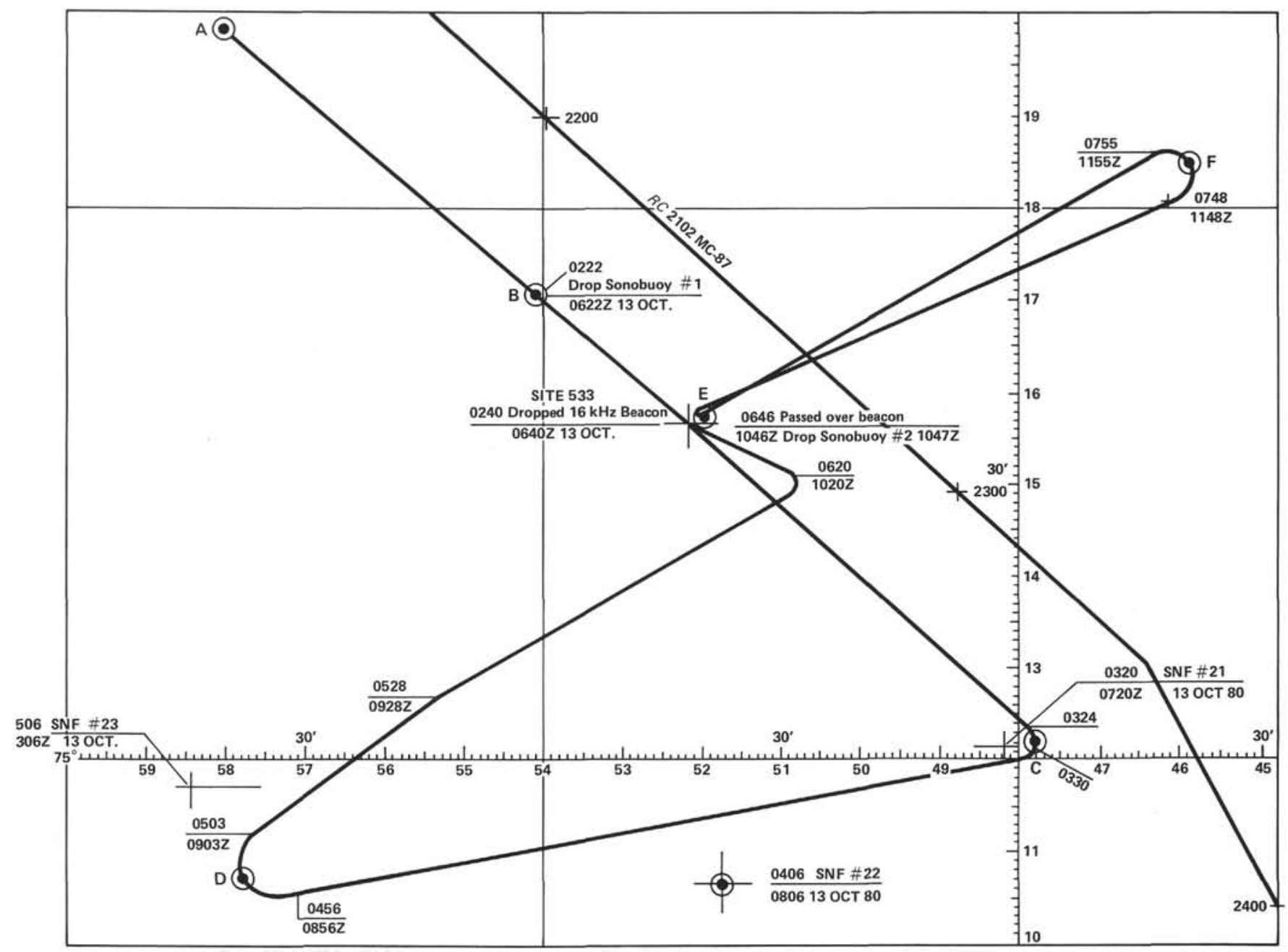

Figure 12. Track lines of the Glomar Challenger through points A, B, C, D, and F at Site 533 (point E). (Also shown is the track of Robert Conrad reference multichannel profile MC-87. Both local time and Greenwich mean time $[\mathrm{Z}]$ are designated.)

Two main lithostratigraphic units distinguished at Holes 533 and 533A are (1) Holocene-Pleistocene (Quaternary), moderately bioturbated, calcareous clay and interbedded nannofossil (silty) marl and silty (nannofossil) clays deposited at an average rate of $8 \mathrm{~cm} / 1000 \mathrm{yr}$.; (2) Pliocene, indurated, dark greenish gray, silty (nannofossil) clay, deposited at a faster average rate, approximately $17 \mathrm{~cm} / 1000 \mathrm{yr}$.

\section{Unit 1}

\section{Holocene-Pleistocene (Quaternary)}

A total thickness of $151 \mathrm{~m}$ of Quaternary material was penetrated at Site 533 . This unit is characterized by interbedded, moderately burrowed nannofossil (silty) marl and silty (nannofossil) clays. Pyrite is frequently present, but smear-slide analysis showed that pyrite does not exceed $5 \%$ and is in places absent, as in Cores 7 and 8 (Fig. 14). Pyrite is sometimes concentrated in worm burrows (Fig. 15). Foraminifers are present throughout the Quaternary, not exceeding $15 \%$ in abundance except in a layer of foraminifer ooze $3 \mathrm{~cm}$ thick, possibly a winnowed zone, found in Core 31 of Hole 533. Calcareous nannofossil abundances range from $0 \%$ in Core 533-34 to $55 \%$ in Core 533-14; however, these are extreme values; the major portion of the Quaternary unit has a calcareous nannofossil percentage that normally ranges between 15 and $45 \%$.

Detrital minerals, such as quartz, feldspars, mica, and heavy minerals occur throughout the Quaternary in varying amounts. The greatest abundance of detrital material occurs in Cores 533-3 through 533-21, corresponding with moderate to high percentages of clay and low percentages of calcareous nannofossils (Fig. 14).

Several important lithologic horizons were encountered in Hole 533 that may correlate with physical property measurements and also several acoustic horizons. In Core 533-7, a "rose mud" was encountered. Another . horizon of gray green, brownish and reddish "muds" was encountered in Cores 533-16 and 533-17, respectively. Both these horizons correspond to peaks in wet-bulk density, as measured in the laboratory, and thus may form distinct acoustic horizons.

Two other lithologic horizons that may be recognizable in the seismic record could be attributed to diagenesis. In Core 533-34, layers of dolomite and barite occur 


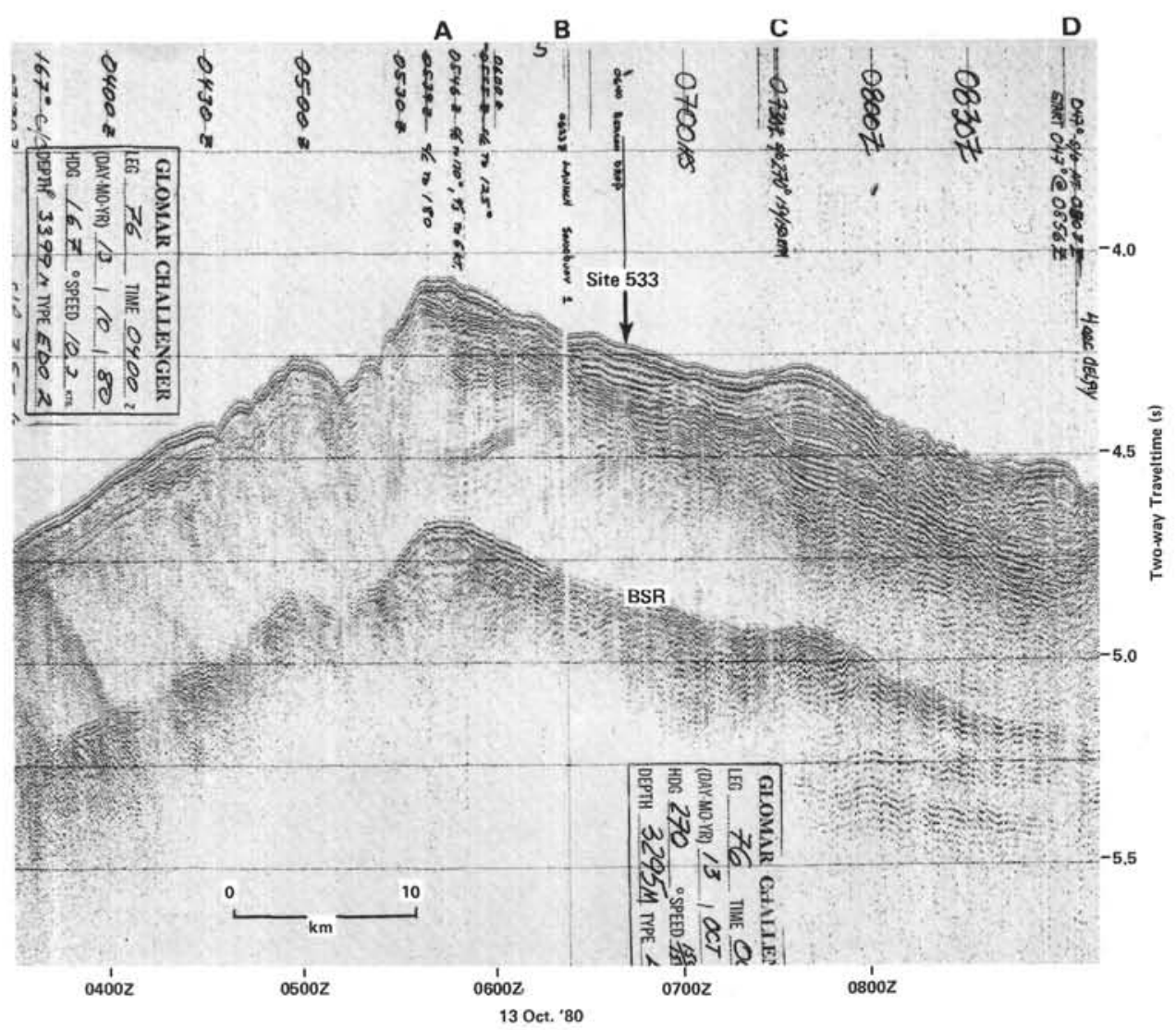

Figure 13. Single-channel seismic reflection profile made from the Glomar Challenger track approaching Site 533. (Points A, B, C, and D are located on Fig. 12.)

in silty sediments (Fig. 16). These sediments are characterized by an absence of quartz, clay, foraminifers, calcareous nannofossils, and siliceous microfossils, indicating that these materials were selectively replaced by dolomite and/or barite. Alternatively, the silty sediments were preferentially introduced by bottom currents. We favor the first explanation, because it is difficult to explain monotypic mineral assemblages by a simple bottom-current transport model.

The moderate sedimentation rate for Unit $1(8 \mathrm{~cm} /$ $1000 \mathrm{yr}$.) and the varying presence of bioturbation throughout indicates that these sediments are of hemipelagic origin, with little influence from major bottom currents (Figs. 17 and 18). The evidence of bottom-current activity is indicated by the presence of silt-sized stringers of dolomite (Fig. 16) and a few abrupt changes in sediment lithology (Fig. 19).

The main objective of Site 533 was to sample gas hydrates in the sediments of the Blake Outer Ridge. The first manifestation of gas in the sediments of Unit 1 appeared as cracks and gaps in Piston Core 10. The degree of disturbance ranges from simple cracks with small (less than $1 \mathrm{~cm}$ ) gaps or voids to much larger (sometimes exceeding $20 \mathrm{~cm}$ ) gap sections (Fig. 20). These particular sections (e.g., 533-20-2; -21,CC; -23-3; and -39-3) may indicate the presence of gas hydrates because of their fragmented character.

The composition of the Quaternary unit and evidence of primary sediment structures suggests that sedimenta- tion may have been hemipelagic, with some input of current-transported detritus. The fluctuations in percentages of calcareous nannofossils and foraminifers in Cores 533-1 through 533-13 exhibit trends that are comparable to those in surface piston cores in the western North Atlantic (Kostecki, 1976; Bé et al., 1976). According to these studies, the sediments with high percentages of foraminifers and nannofossils were deposited during interglacial periods; conversely, sediments with low percentages were deposited during glacial periods. Smear-slide analyses of the upper portion of the Quaternary unit show an increase in terrigenous material during glacial periods and a decrease during the interglacial, suggesting sedimentation processes affected closely by Pleistocene climatic changes. Although there is some evidence of sporadic current action in the form of winnowed deposits and abrupt lithologic changes, there does not appear to be much current influence in Unit 1.

\section{Unit 2}

\section{Middle to Late Pliocene}

The Pliocene unit cored at Holes 533 and 533A is characterized by stiff, medium to dark greenish gray silty (nannofossil) clays. At Hole 533, the total recovery of Pliocene material amounted to about $14 \mathrm{~m}$; however, at Hole 533A, $219 \mathrm{~m}$ of Pliocene material were cored and $173.3 \mathrm{~m}$ recovered. 


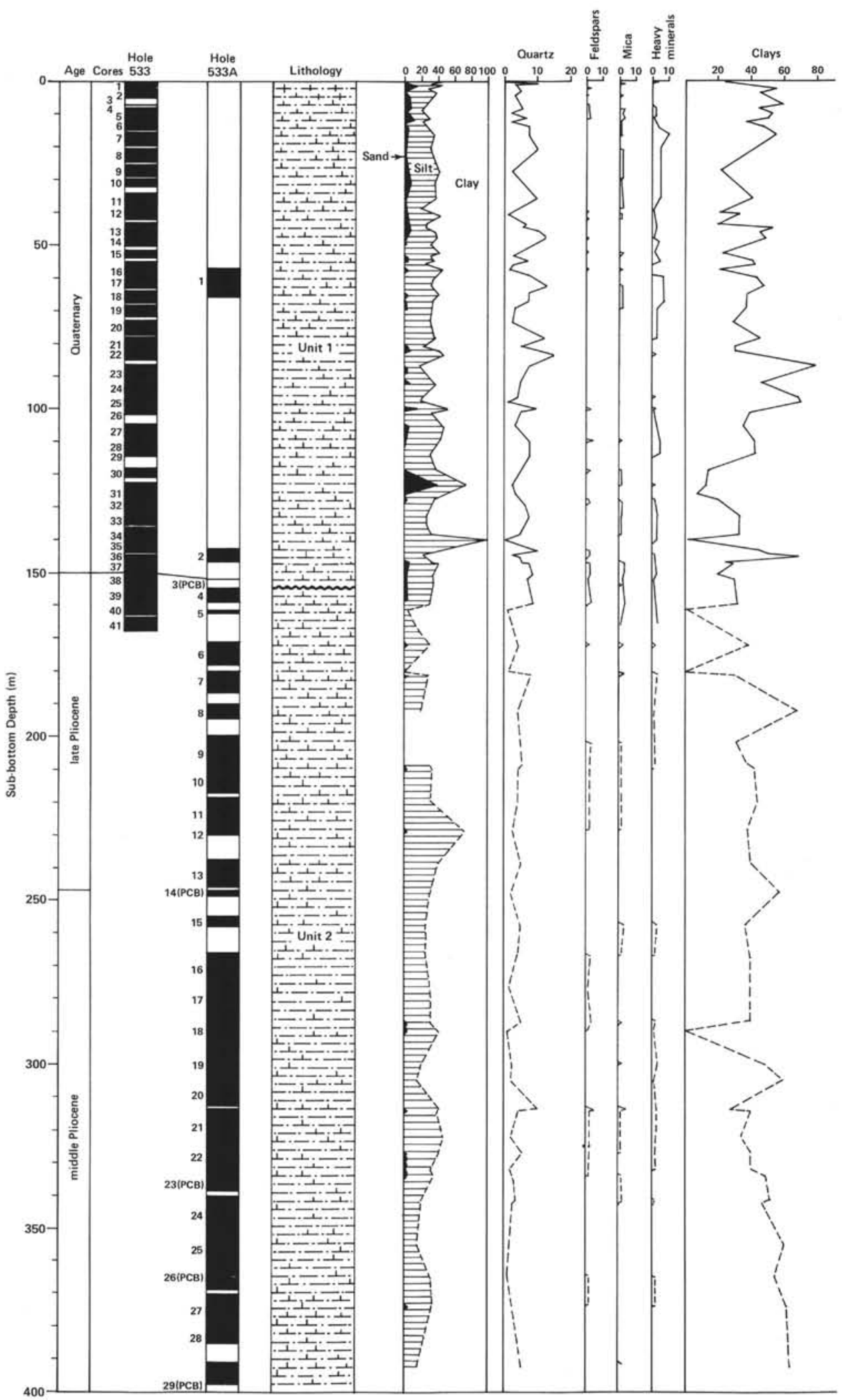

Figure 14. Downcore smear-slide analyses of cores from Site 533 (Holes 533 and 533A). (Solid lines represent concentrations of sediment constituents in Hole 533; dashed lines represent concentrations of constituents in Hole 533A.) 


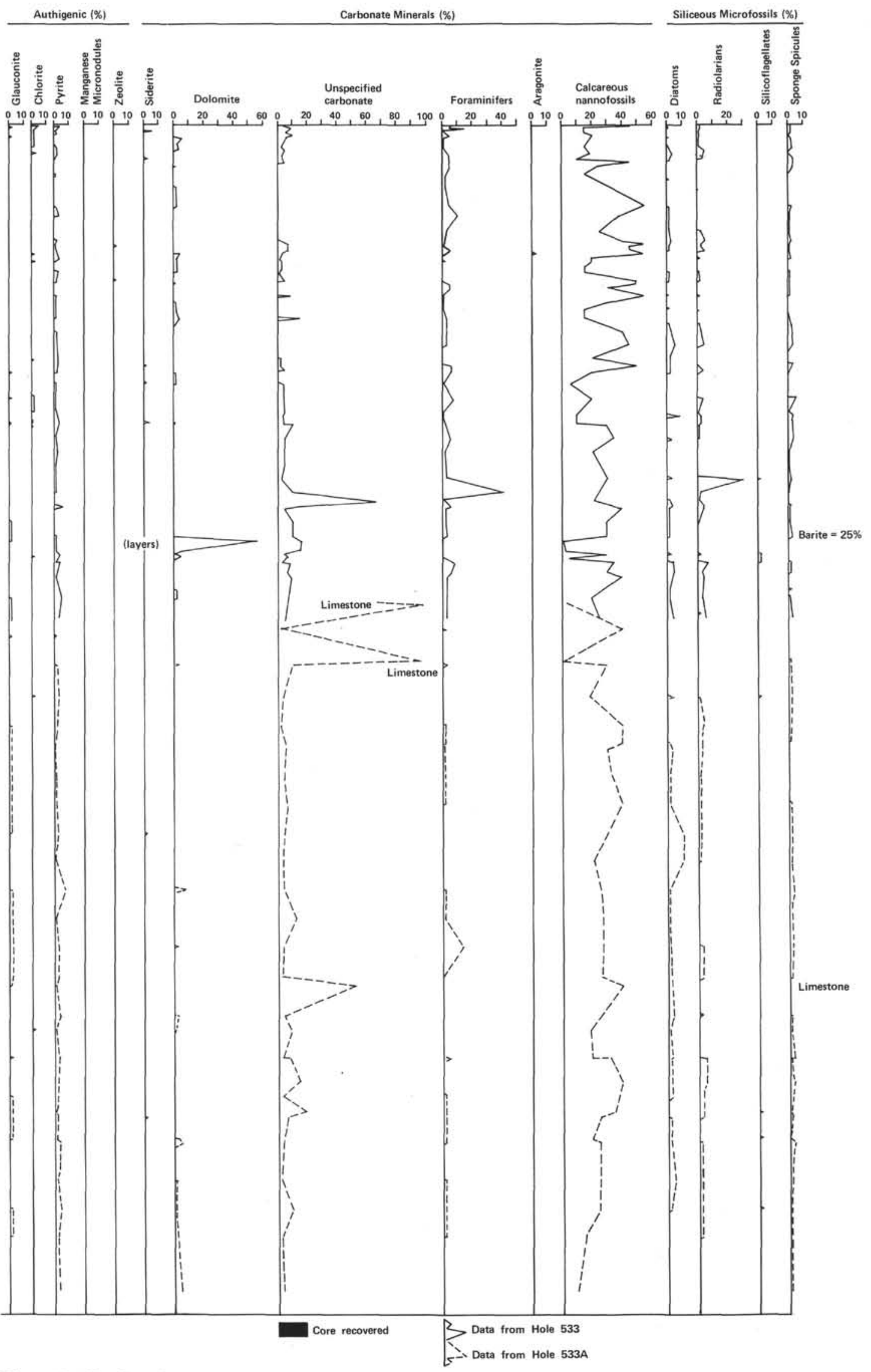

Figure 14. (Continued). 
Table 1. Coring summary, Site 533.

\begin{tabular}{|c|c|c|c|c|c|c|}
\hline $\begin{array}{c}\text { Core } \\
\text { no. }\end{array}$ & $\begin{array}{l}\text { Total depth } \\
\text { (m) }\end{array}$ & $\begin{array}{l}\text { Sub-bottom } \\
\text { depth } \\
\text { (m) }\end{array}$ & $\begin{array}{l}\text { Cored } \\
(\mathrm{m})\end{array}$ & $\begin{array}{l}\text { Recovered } \\
\text { (m) }\end{array}$ & Lithology & Age \\
\hline \multicolumn{7}{|c|}{ Hole 533} \\
\hline 1 & $3183.8-3186.5$ & $0.0-2.7$ & 2.7 & 2.7 & Gray green mud & $\begin{array}{l}\text { Holocene-late } \\
\text { Pleistocene }\end{array}$ \\
\hline 2 & $3186.5-3191.0$ & $2.7-7.2$ & 4.5 & 2.4 & Gray green mud & late Pleistocene \\
\hline 3 & $3191.0-3192.0$ & $7.2-8.2$ & 0.1 & 0.1 & Gray green mud & late Pleistocene \\
\hline 4 & $3192.0-3192.2$ & $8.2-8.4$ & 0.2 & 0.2 & Gray green mud & late Pleistocene \\
\hline 5 & $3192.2-3195.2$ & $8.4-11.4$ & 3.0 & 3.0 & Gray green mud & late Pleistocene \\
\hline 6 & $3195.2-3199.7$ & $11.4-15.9$ & 4.5 & 4.2 & Gray green mud & late Pleistocene \\
\hline 7 & $3199.7-3204.2$ & $15.9-20.4$ & 4.5 & 3.8 & Rose mud & late Pleistocene \\
\hline 8 & $3204.2-3208.7$ & $20.4-24.9$ & 4.5 & 3.8 & Gray green mud & late Pleistocene \\
\hline 9 & $3208.7-3213.2$ & $24.9-29.4$ & 4.5 & 4.1 & Gray green mud & late Pleistocene \\
\hline 10 & $3213.2-3217.7$ & $29.4-33.9$ & 4.5 & 2.4 & Gray green mud & late Pleistocene \\
\hline 11 & $3217.7-3222.2$ & $33.9-38.4$ & 4.5 & 4.3 & Gray green mud & late Pleistocene \\
\hline 12 & $3222.2-3226.7$ & $38.4-42.9$ & 4.5 & 3.8 & Gray green mud & late Pleistocene \\
\hline 13 & $3226.7-3230.8$ & $42.9-47.0$ & 4.1 & 4.1 & $\begin{array}{l}\text { Gray green dark } \\
\text { green mud }\end{array}$ & late Pleistocene \\
\hline 14 & $3230.8-3235.3$ & $47.0-51.5$ & 4.5 & 3.4 & Gray green mud & late Pleistocene \\
\hline 15 & $3235.3-3239.8$ & $51.5-55.0$ & 4.5 & 3.4 & Gray green mud & late Pleistocene \\
\hline 16 & $3239.8-3244.3$ & $55.0-59.5$ & 4.5 & 4.5 & $\begin{array}{l}\text { Gray green } \\
\text { brownish mud }\end{array}$ & middle Pleistocene \\
\hline 17 & $3244.3-3248.8$ & $59.5-64.0$ & 4.5 & 3.9 & $\begin{array}{l}\text { Gray green } \\
\text { reddish mud }\end{array}$ & middle Pleistocene \\
\hline 18 & $3248.8-3253.3$ & $64.0-68.5$ & 4.5 & 3.6 & Gray green mud & middle Pleistocene \\
\hline 19 & $3253.3-3257.8$ & $68.5-73.0$ & 4.5 & 3.3 & Gray green mud & middle Pleistocene \\
\hline 20 & $3257.8-3262.3$ & $73.0-77.5$ & 4.5 & 4.2 & Gray green mud & middle Pleistocene \\
\hline 21 & $3262.3-3266.8$ & $77.5-82.0$ & 4.5 & 4.1 & Gray green mud & middle Pleistocene \\
\hline 22 & $3266.8-3271.3$ & $82.0-86.5$ & 4.5 & 3.2 & Gray green mud & middle Pleistocene \\
\hline 23 & $3271.3-3275.8$ & $86.5-91.0$ & 4.5 & 4.5 & Gray green mud & middle Pleistocene \\
\hline 24 & $3275.8-3280.3$ & $91.0-95.5$ & 4.5 & 4.7 & Gray green mud & middle Pleistocene \\
\hline 25 & $3280.3-3284.8$ & $95.5-100.0$ & 4.5 & 4.5 & Gray green mud & early Pleistocene \\
\hline 26 & $3284.8-3289.3$ & $100.0-104.5$ & 4.5 & 1.8 & Gray green mud & early Pleistocene \\
\hline 27 & $3289.3-3293.8$ & $104.5-109.0$ & 4.5 & 4.4 & Gray green mud & early Pleistocene \\
\hline 28 & $3293.8-3298.3$ & $109.0-113.5$ & 4.5 & 4.5 & Gray green mud & early Pleistocene \\
\hline 29 & $3298.3-3302.8$ & $113.5-118.0$ & 4.5 & 1.1 & Dark gray mud & early Pleistocene \\
\hline 30 & $3302.8-3308.3$ & $118.0-122.5$ & 4.5 & 3.0 & Dark gray mud & early Pleistocene \\
\hline 31 & $3308.3-3312.8$ & $122.5-127.0$ & 4.5 & 4.4 & Gray green mud & early Pleistocene \\
\hline 32 & $3312.8-3317.3$ & $127.0-131.5$ & 4.5 & 4.6 & Gray green mud & early Pleistocene \\
\hline 33 & $3317.3-3321.8$ & $131.5-136.0$ & 4.5 & 4.2 & Gray green mud & early Pleistocene \\
\hline 34 & $3321.8-3326.3$ & $136.0-140.5$ & 4.5 & 4.6 & Gray green mud & early Pleistocene \\
\hline 35 & $3326.3-3330.8$ & $140.5-145.0$ & 4.5 & 4.1 & Gray green mud & early Pleistocene \\
\hline 36 & $3330.8-3332.3$ & $145.0-146.5$ & 1.5 & 1.5 & Gray green mud & early Pleistocene \\
\hline 37 & $3332.3-3335.3$ & $146.5-149.5$ & 3.0 & 3.5 & Gray green mud & early Pleistocene \\
\hline 38 & $3335.3-3339.8$ & $149.5-154.0$ & 4.5 & 4.6 & Gray green mud & early Pleistocene \\
\hline 39 & $3339.8-3344.3$ & $154.0-158.5$ & 4.5 & 4.6 & Dark green mud & early Pleistocene \\
\hline 40 & $3344.3-3348.8$ & $158.5-163.0$ & 4.5 & 4.3 & Dark green mud & early Pleistocene \\
\hline 41 & $3348.8-3352.3$ & $163.0-167.6$ & 4.5 & 4.6 & Dark green mud & $\begin{array}{l}\text { Pliocene- } \\
\text { Pleistocene }\end{array}$ \\
\hline \multicolumn{7}{|c|}{ Hole 533A } \\
\hline 1 & $3241.0-3250.5$ & $57.0-66.0$ & 9.5 & 10.5 & Gray green mud & late Pleistocene \\
\hline 2 & $3326.5-3335.0$ & $142.5-152.0$ & 9.5 & 4.0 & Gray green mud & late Pleistocene \\
\hline 3 & $3336.0-3343.8$ & $152.0-154.5$ & 2.5 & 6.4 & Gray green mud & late Pleistocene \\
\hline 4 & $3338.5-3345.5$ & $154.5-161.5$ & 7.0 & 4.5 & Gray green mud & late Pleistocene \\
\hline 5 & $3345.5-3355.0$ & $161.5-171.0$ & 9.5 & 10.8 & Gray green mud & late Pleistocene \\
\hline 6 & $3355.0-3364.5$ & $171.0-180.5$ & 9.5 & 7.1 & Gray green mud & $\begin{array}{l}\text { earliest } \\
\quad \text { Pleistocene }\end{array}$ \\
\hline 7 & $3364.5-3374.0$ & $180.5-190.0$ & 9.5 & 6.1 & Gray green mud & late Pliocene \\
\hline 8 & $3374.0-3383.5$ & $190.0-199.5$ & 9.5 & 4.4 & Gray green mud & late Pliocene \\
\hline 9 & $3383.5-3393.0$ & $199.5-209.0$ & 9.5 & 9.4 & Gray green mud & late Pliocene \\
\hline 10 & $3393.0-3402.5$ & $209.0-218.5$ & 9.5 & 8.0 & Gray green mud & late Pliocene \\
\hline 11 & $3402.5-3412.0$ & $218.5-228.0$ & 9.5 & 9.8 & Gray green mud & late Pliocene \\
\hline 12 & $3412.0-3421.5$ & $228.0-237.5$ & 9.5 & 2.0 & Gray green mud & late Pliocene \\
\hline 13 & $3421.5-3431.0$ & $237.5-247.0$ & 9.5 & 8.4 & Gray green mud & middle Pliocene \\
\hline \multicolumn{7}{|c|}{ Gas hydrate directly observed } \\
\hline 14 & $3431.0-3438.8$ & $247.0-254.8$ & 7.8 & 1.6 & Gray green mud & middle Pliocene \\
\hline 15 & $3440.5-3450.0$ & $256.5-266.0$ & 9.5 & 2.9 & Gray green mud & middle Pliocene \\
\hline 16 & $3450.0-3459.5$ & $266.0-275.5$ & 9.5 & 9.8 & Gray green mud & middle Pliocene \\
\hline 17 & $3459.5-3469.0$ & $275.5-285.0$ & 9.5 & 9.6 & Gray green mud & middle Pliocene \\
\hline 18 & $3469.0-3478.5$ & $285.0-294.5$ & 9.5 & 9.8 & Gray green mud & middle Pliocene \\
\hline 19 & $3478.5-3488.0$ & $294.5-304.0$ & 9.5 & 9.7 & Gray green mud & middle Pliocene \\
\hline 20 & $3488.0-3497.5$ & $304.0-313.5$ & 9.5 & 8.9 & Gray green mud & middle Pliocene \\
\hline 21 & $3497.5-3507.0$ & $313.5-323.0$ & 9.5 & 9.8 & Gray green mud & middle Pliocene \\
\hline 22 & $3507.0-3516.5$ & $323.0-322.5$ & 9.5 & 9.8 & Gray green mud & middle Pliocene \\
\hline 23 & $3516.5-3526.0$ & $323.5-340.3$ & 7.8 & 6.1 & Gray green mud & middle Pliocene \\
\hline 24 & $3526.0-3535.5$ & $342.0-351.5$ & 9.5 & 9.8 & Gray green mud & middle Pliocene \\
\hline 25 & $3535.5-3545.0$ & $351.5-361.0$ & 9.5 & 9.7 & Gray green mud & middle Pliocene \\
\hline 26 & $3545.0-3552.8$ & $361.0-368.8$ & 7.8 & 6.1 & Gray green mud & middle Pliocene \\
\hline 27 & $3554.5-3564.0$ & $370.5-380.0$ & 9.5 & 9.8 & Gray green mud & middle Pliocene \\
\hline 28 & $3564.0-3573.5$ & $380.0-389.5$ & 9.5 & 2.5 & Gray green mud & middle Pliocene \\
\hline 29 & $3575.2-3583.0$ & $392.2-399.0$ & 7.8 & 6.2 & Gray green mud & middle Pliocene \\
\hline
\end{tabular}




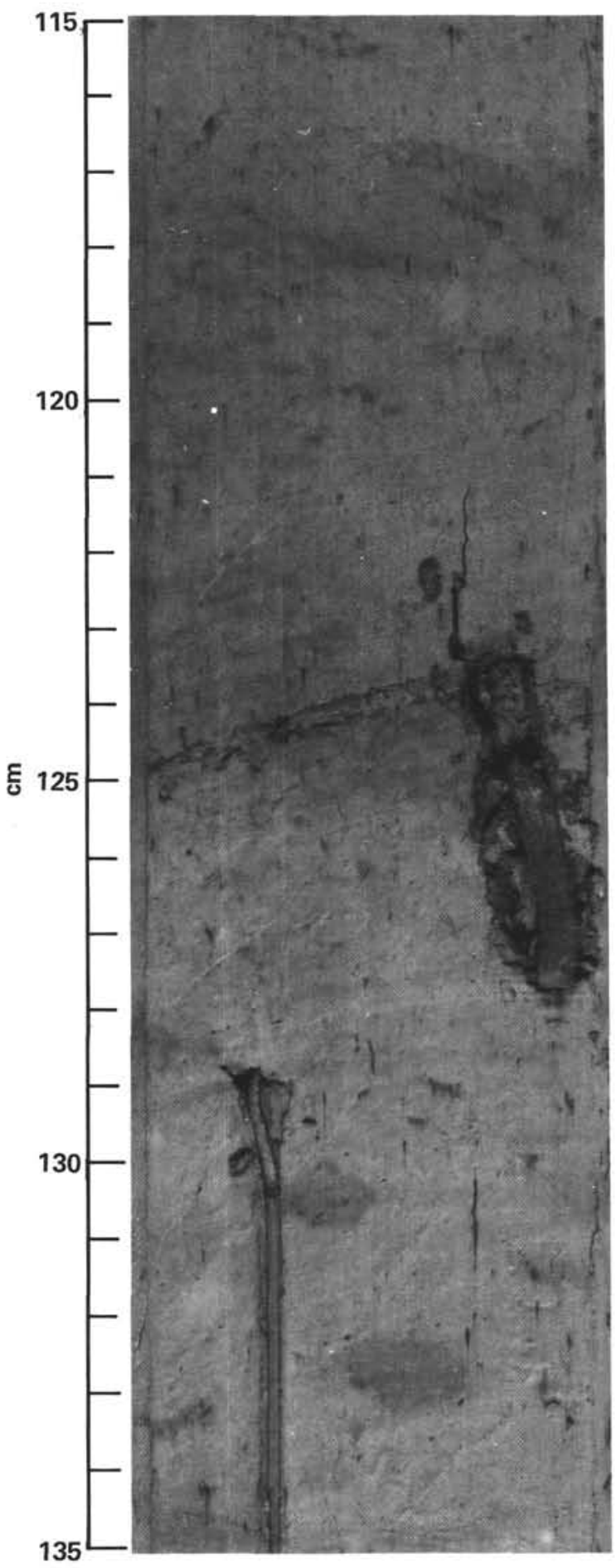

Figure 15. Close-up of Sample 533-21-1, 115-135 cm showing two pyritized worm burrows.

The Pliocene sediments are conspicuous because of (1) the lack of bioturbation (except for an occasional pyritized worm burrow); (2) the "fissile" texture; and (3) the distinctive hydrocarbon odor apparent on board the ship. Mineralogically the Pliocene sediments are not significantly different from the overlying Quaternary unit; both contain pyrite (up to $5 \%$ ), quartz and other detritals (between 10 and $20 \%$ ), and clays (normally be-

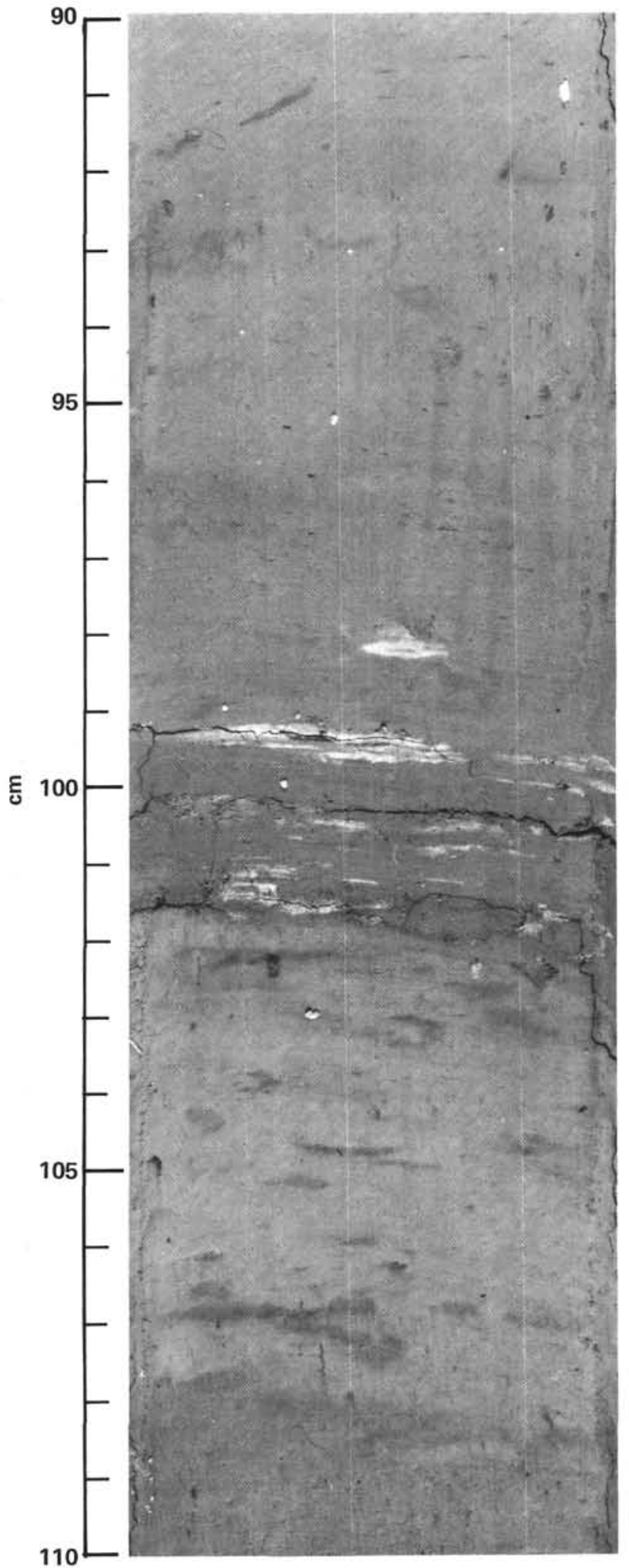

Figure 16. Close-up of Sample 533-34-3, 90-110 cm showing an occurrence of thin layers of dolomite and barite grains. (The presence of these layers may be indicative of short intervals of current activity on the crest of the Blake Outer Ridge during the early Pleistocene. The lack of silt-sized material and other background sediment components, such as quartz, clays, calcareous microfossils, or siliceous microfossils, indicates a period of winnowing.) 


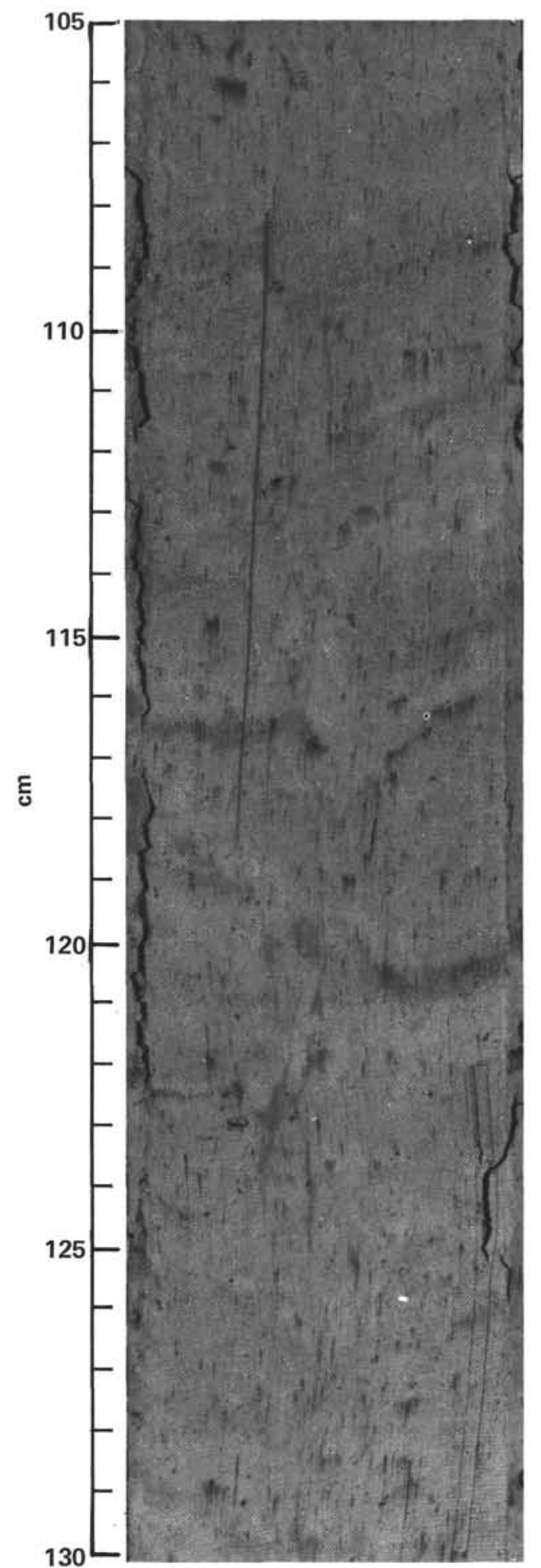

Figure 17. Close-up of Sample 533-33-1, 105-130 cm showing moderately bioturbated sediments.

tween 30 and $60 \%$ ). Calcareous nannofossil abundances range between 10 and $40 \%$; however, there is a distinct lack of foraminifers in the Pliocene unit, which, when compared with the increased amounts of unspecified calcite (micrite), suggests that dissolution took place extensively. The presence of limestone nodules in Cores

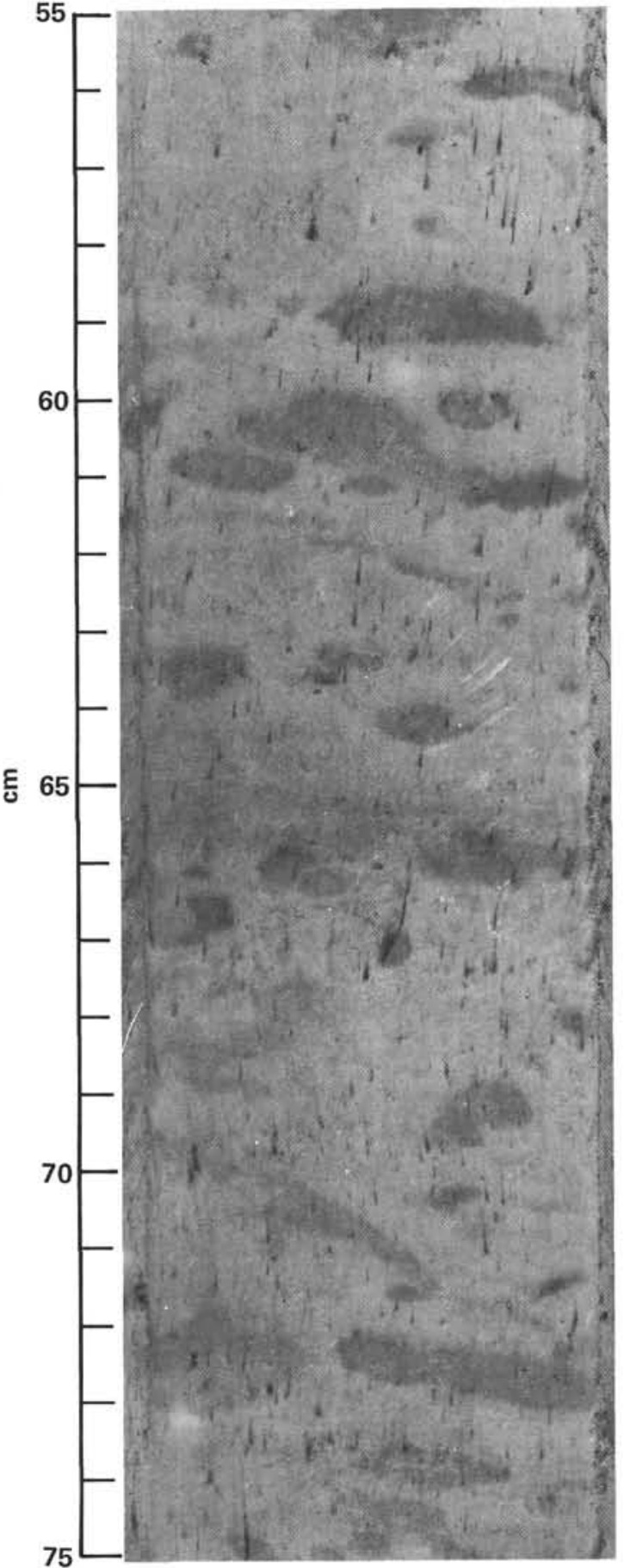

Figure 18. Close-up of Sample 533-27-3, 55-75 cm showing intensely bioturbated Pleistocene sediments.

533A-5 and 533A-7 (Figs. 21 and 22) coincidental with high percentages of micrite and low percentages of detritals, clays, and calcareous nannofossils indicates there have also been periods of diagenesis in the Pliocene sediments. These nodules are significant in that they suggest the presence of two acoustic horizons within the late Pliocene unit.

At Holes 533 and 533A, lithified limestone concretions up to $5 \mathrm{~cm}$ thick (Sections 533A-5-1, 533A-7-1, 


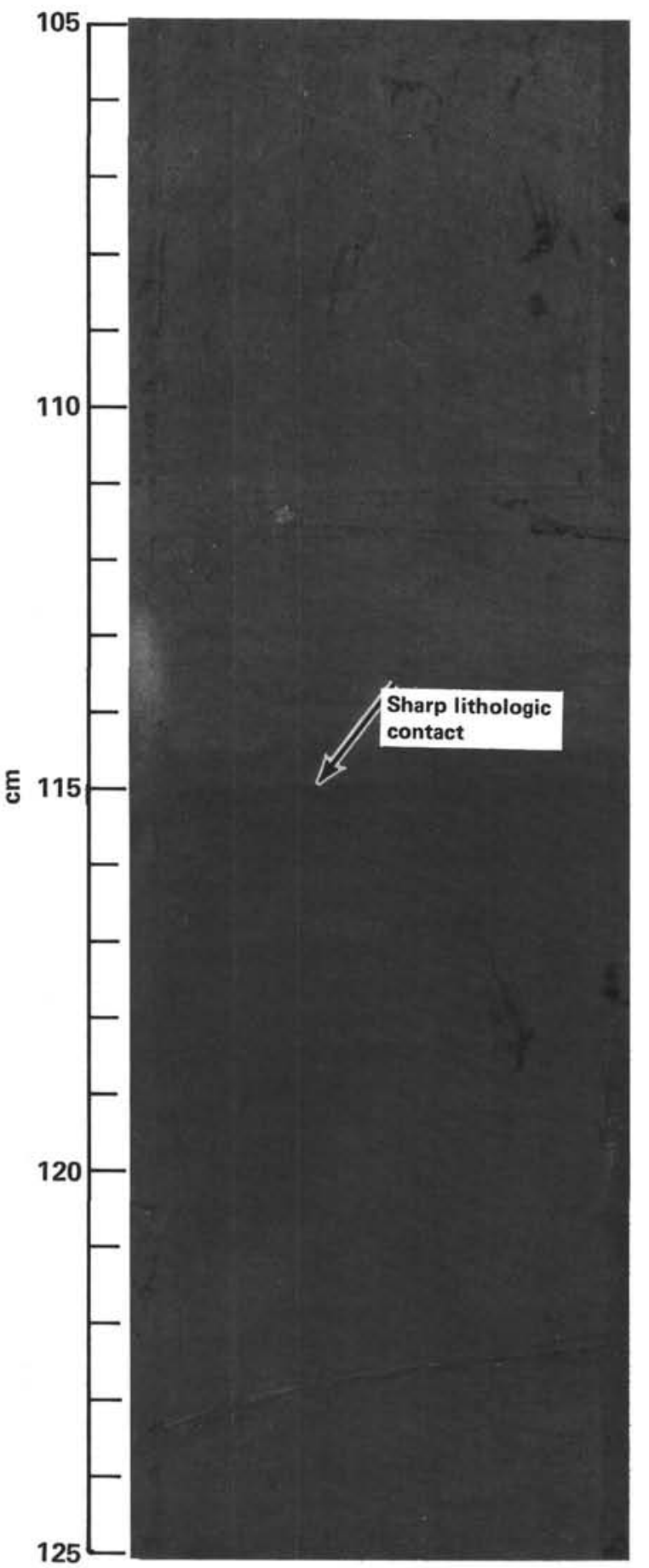

Figure 19. Close-up of Sample 533-38-3, 105-125 cm showing an abrupt change in lithology from a bluish gray nannofossil, silty clay to terrigenous clay at $115 \mathrm{~cm}$. (This boundary may indicate an abrupt change in sedimentation from current-derived terrigenous material to hemipelagic sedimentation in a more tranquil environment.)

and 533A-18-4) are evidence for carbonate and silica diagenesis in several of the medium greenish gray intervals. In smear slides, much of the material is composed of unspecified carbonate $(75 \%)$ or micrite, of microsilt size. At high magnification $(600 \times)$, detrital feldspar and quartz grains are seen to be partly or completely re-

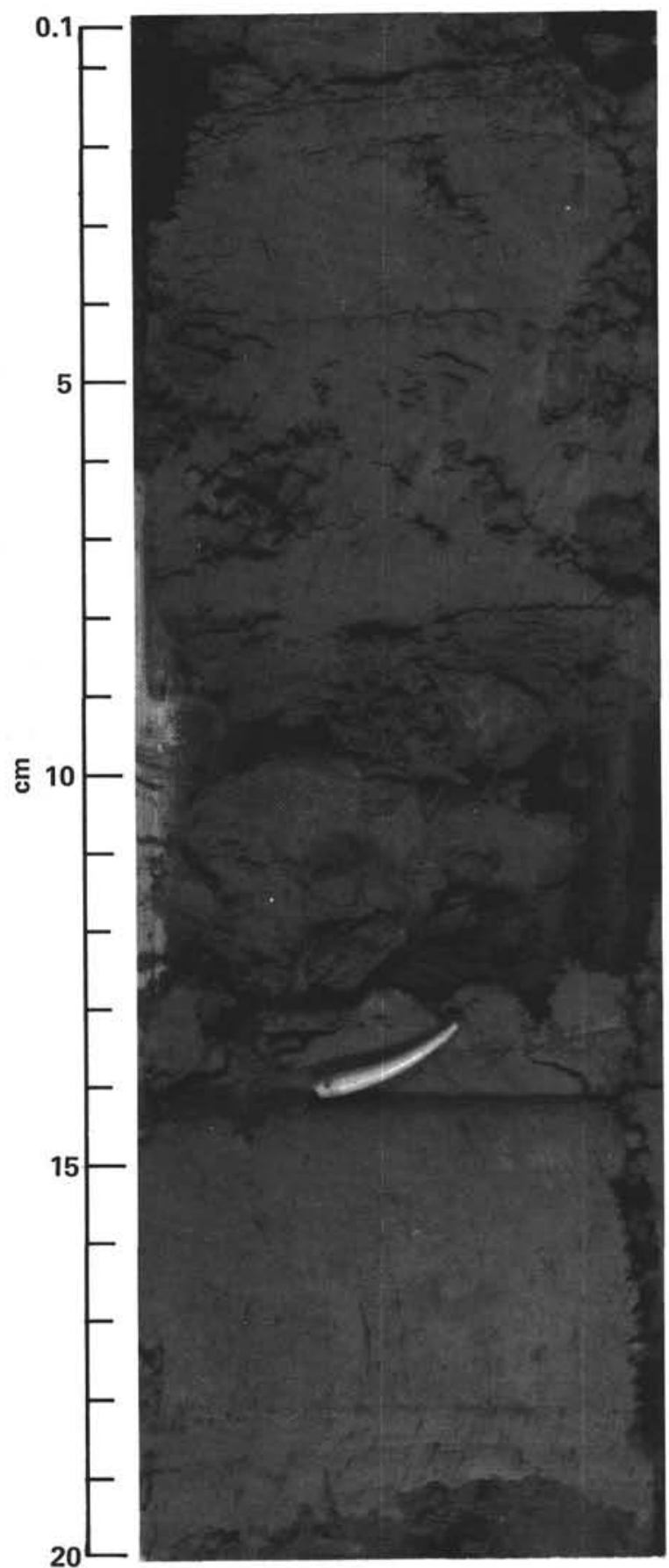

Figure 20. Close-up of Sample 533-21,CC $(0-20 \mathrm{~cm})$ showing badly fragmented material as well as some gaps in the core. (The high degree of fragmentation in such sections as this may be indicative of outgassing due to the disintegration of gas hydrate rather than simple outgassing of free or dissolved gases from the sediment matrix.)

placed by calcite. By contrast, in these intervals, siliceous microfossils are normally absent, with the exception of rare sponge spicules.

\section{Discussion}

The lithology of sediments recovered in Holes 533 and 533A does not differ from that of sediments of similar age recovered from Sites 102, 103, and 104 on DSDP 


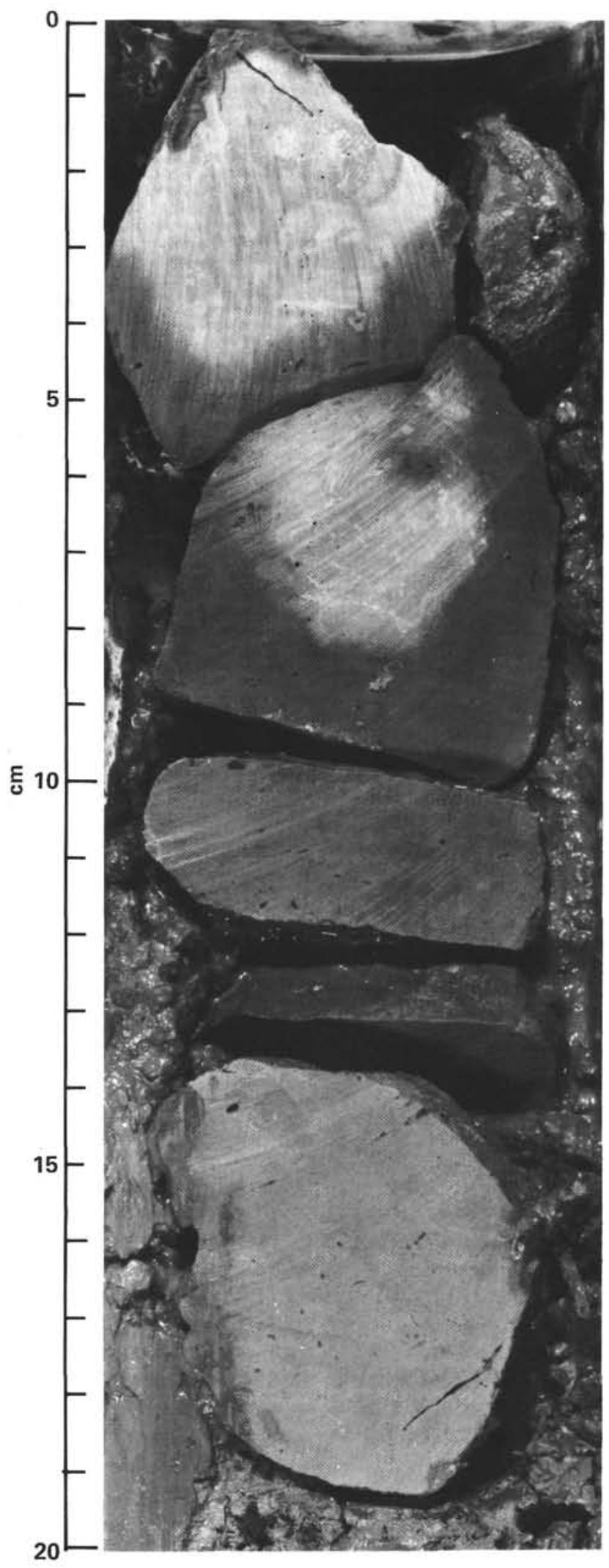

Figure 21. Close-up photograph of Sample 533A-5-1, 0-20 cm showing limestone nodules cored in the upper section of Unit 2. (Associated decreases in the abundances of carbonate microfossils [foraminifers and calcareous nannofossils] and the total dominance of unspecified carbonate at this interval suggest diagenetic recrystallization.)

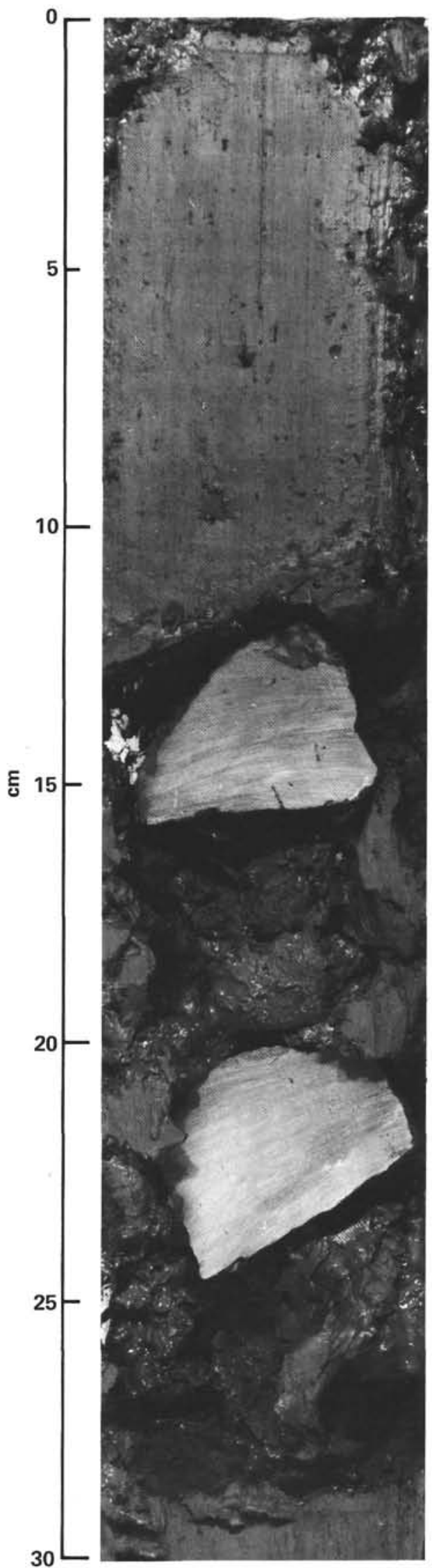

Figure 22. Close-up of Sample 533A-7-1, 0-30 cm showing limestone nodules similar to those found in Sample 533A-5-1, 0-20 cm (Fig. 21). 
Leg 11 (Hollister et al., 1972b). Previous drilling on the Blake Outer Ridge revealed a sedimentation rate for the Quaternary far in excess of that found at Site 533. At Site 102, the Holocene-Pleistocene (Quaternary) sedimentation rate was estimated at about $14 \mathrm{~cm} / 1000 \mathrm{yr}$., nearly twice as large as the rate of $8 \mathrm{~cm} / 1000 \mathrm{yr}$. estimated for Site 533. This apparent discrepancy in sedimentation rates is explained by the wedge-shaped configuration of the Quaternary unit seen in seismic records (Fig. 23). The geometry of the Pliocene sediments as seen in seismic records is consistent with the interpretation of this unit as a contourite mound (Mitchum et al., 1977).

As with the cores obtained in the Pliocene and Pleistocene sediments in Hole 533, there was much indirect evidence of gas in Unit 2-the gaps in the cored sections. The only direct evidence of gas hydrates was obtained in Section 533A-13-1 (Fig. 24). Although there did not appear to be any sedimentologic changes associated with the clathrates (gas hydrates), the fragmented nature of the sediments may serve as indirect evidence of possible clathrate occurrences in other levels at Site 533 (see the discussion on Lithologic Unit 1). This type of "disturbance texture" also occurs in Core 533A-3 (PCB), where it was first encountered in Hole 533A, and also in Sections 533-20-2; -21,CC; $-23-3$; and -39-3. If this association between clathrate occurrence and fragmented texture is real, then the occurrence of clathrate "horizons" higher in the section would be suggested. This textural relationship, although not proven by the drilling results at this site, may prove helpful during future drilling programs in areas associated with clathrates.

\section{BIOSTRATIGRAPHY}

\section{Introduction}

Thick sections of $151 \mathrm{~m}$ of Pleistocene and $248 \mathrm{~m}$ of upper and middle Pliocene were cored continuously at Site 533. The Pleistocene section and $18 \mathrm{~m}$ of the Pliocene section were recovered in Hole 533. Hole 533A was washed down to $57 \mathrm{~m}$, where an upper Pleistocene core was taken; continuous coring started with Core 4 in the upper Pliocene and ended with Core 29 in the middle Pliocene.

Planktonic foraminifers and calcareous nannofossils are generally common to abundant and well to moderately well preserved. Diversity is relatively great, and the calcareous planktonic assemblages show a tropical to subtropical aspect, with some colder water forms. A Holocene planktonic foraminiferal assemblage was tentatively identified in the uppermost part of Core 533-1. The Pleistocene interval can be subdivided into three parts on the basis of planktonic foraminiferal datums and into six nannofossil zones. The Pliocene/Pleistocene boundary is placed within Core 533-38, based on both fossil groups.

Pliocene planktonic foraminiferal and nannofossil assemblages are diverse and generally well preserved. All calcareous planktonic zones are present, but the uppermost Pliocene nannoplankton zones are very much reduced in thickness. Planktonic foraminifers also indi- cate reduced sedimentation for the same interval. Three nannoplankton zones and one planktonic foraminiferal zone were recognized in the upper Pliocene. The middle Pliocene was recovered in the lower part of Hole 533A; it is very thick and seems fairly complete. The early disappearance of Sphenolithus abies at this site is noteworthy.

Few to rare benthic foraminifers occur throughout the intervals recovered. Only one Pliocene sample (533$40, C C$ ) is rich in benthic foraminifers. Ostracodes are generally rare in the lower Pleistocene and the Pliocene. Rich diatom assemblages were observed in most of the Pliocene cores, and particularly in Cores 533A-12 and -13 . Few radiolarians have also been observed in Cores 533-31 and 533A-9.

\section{Foraminifers}

The 41 cores of Hole 533 contain Quaternary and uppermost Pliocene foraminifer assemblages. The Quaternary is approximately $150 \mathrm{~m}$ thick, and about $18 \mathrm{~m}$ of Pliocene sediments were also recovered.

Assemblages of rich and rather well preserved planktonic foraminifers occur throughout Hole 533, with the exception of the three last cores (39-41), where the abundance of foraminifers decreases and preservation becomes moderate. In these oldest cores, and particularly in Core 40 , there is a relative increase in percentage of benthic forms, such as miliolids, nodosarids, uvigerinids, etc., over planktonics. In all the other cores percentages of planktonics always exceed 80 to $85 \%$ and may even reach $95 \%$ in some samples (for instance, 533$12, \mathrm{CC} ;-16, \mathrm{CC} ;-17, \mathrm{CC} ;-22, \mathrm{CC} ;-26, \mathrm{CC})$.

Throughout the sampled interval there are important variations in the occurrences and percentages of keeled planktonic foraminifers. These variations are probably related to climatic factors. Sudden decreases of keeled forms, for instance, have been observed in Samples 533$19, \mathrm{CC},-36, \mathrm{CC}$, and $-40, \mathrm{CC}$. Further detailed investigations of additional samples may correlate such trends and other microfaunal and microfloral climatic indicators with known Quaternary glacial events.

A presumably Holocene assemblage has been found in Sample 533-1-1, 14-16 cm, including principally Globorotalia truncatulinoides, G. tumida tumida (common), few $G$. ungulata (which almost completely disappear below this level), G. tumida flexuosa, G. hirsuta, Globigerinoides ruber (pink), G. conglobatus, and rare Globorotalia inflata and Globigerina (Neogloboquadrina) dutertrei.

Core-catcher samples from Cores 1 to 37 have provided Pleistocene assemblages that essentially comprise Globorotalia truncatulinoides, G. tumida tumida, G. hirsuta, G. inflata, G. crassaformis, Globigerinoides ruber, G. conglobatus, Globigerina (Neogloboquadrina) dutertrei, Orbulina universa, and, more rarely, Globorotalia scitula, Globigerinoides trilobus, G. sacculifer, Sphaeroidinella dehiscens dehiscens. Pulleniatina finalis is only found in the upper part and Globorotalia tosaensis in the lower part of this sequence.

The Pliocene/Pleistocene boundary has been defined using the Globorotalia truncatulinoides FAD (first ap- 


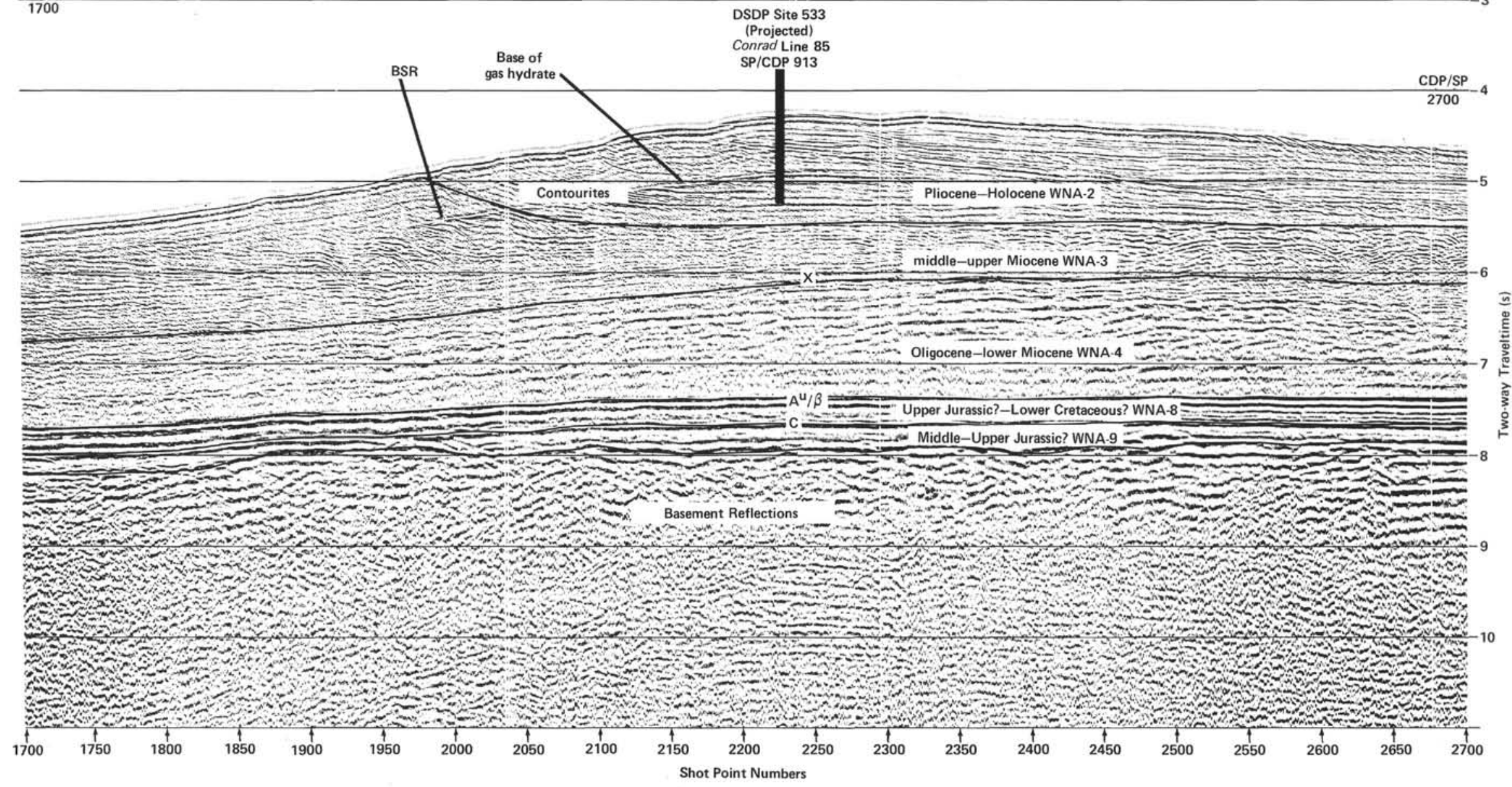

Figure 23. Part of Line MC-85, taken aboard Robert D. Conrad Cruise 2102. (The interpretation of chronostratigraphic horizons and reflector nomenclature are based on work by Shipley et al. [1978] and Bryan and Markl [personal communication, 1982]. A thin drape of Pleistocene-Holocene sediment, unresolvable in the seismic profile, is present on the eastern flank of the Blake nondepositional currents on the eastern flank throughout most of the Pleistocene.) 


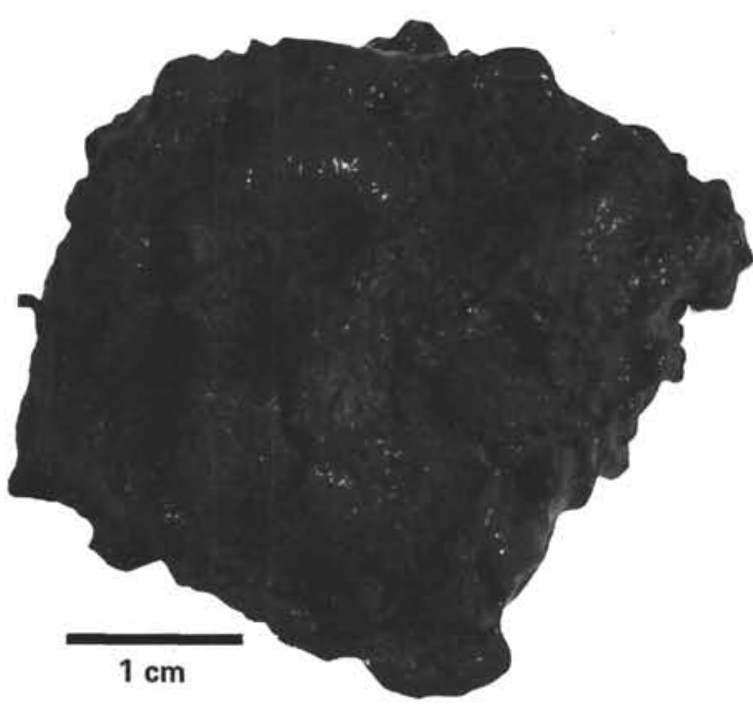

Figure 24. Close-up photograph of Sample 533A-13-1, $26 \mathrm{~cm}$ showing the gas hdyrate (clathrate) sample recovered in the Pressure Core Barrel. (Special note should be taken of the fragmented nature of the sediments, possibly caused by the deterioration of the clathrate and subsequent disruption of layers by degassing.)

pearance datum), which corresponds here to the bottom of Core 37.

Based on several other datums it has also been possible to divide the Pleistocene muds (= Blow's Zones N22-N23) into three parts. The lower boundary of the upper part (Cores 1-15) is based on Pulleniatina finalis $\mathrm{FAD}$, and this interval therefore corresponds to the late Pleistocene (Stainforth et al., 1975). The intermediate part (Cores 16-23) and the lower part (Cores 24-37) are assigned to the middle and early Pleistocene, respectively. The boundary between these two subdivisions is here provisionally defined by the Globorotalia tosaensis LAD (last appearance datum).

In Cores 38 to 41 Globorotalia crassaformis, Globigerinoides spp., and Globigerina gr. humerosa-dutertrei occur, as well as Globorotalia miocenica, G. pertenuis, and Sphaeroidinella dehiscens immatura. Consequently, Cores 38 to 41 have been placed in the Pliocene (part of Zone N21), based on the simultaneous occurrence of $S$. dehiscens immatura and G. miocenica (Stainforth et al., 1975).

The shipboard investigations could not discern any gap in the sedimentation; based on foraminifer occurrence, the upper Neogene sequence, as cored in Hole 533 , seems to be continuous. Nevertheless, in this hole an important discrepancy does appear. On the one hand, there is the time interval that separates two important foraminiferal datums $(G$. truncatulinoides FAD: 1.9 m.y., G. miocenica LAD: 2.75 m.y., Berggren and Van Couvering, 1974); on the other hand, there is the thickness of sediments (maximum 4, $5 \mathrm{~m}$ ) that separates the two samples $(37, \mathrm{CC}, 38, \mathrm{CC})$ from which these datums have been deduced. This observation leads us to consider a very low sedimentation rate (maximum, 5.3 $\mathrm{m} / \mathrm{m} . \mathrm{y}$.) for this period, which is of the same order as the low sedimentation rate $(10 \mathrm{~m} / \mathrm{m} . \mathrm{y}$.) calculated from the nannofossil datums (see Fig. 25).
The stratigraphic ranges of the most important species of planktonic foraminifers that have been found in the samples collected from Hole 533 are shown in Figure 26.

The 29 cores of Hole 533A contain Quaternary and upper and middle Pliocene foraminifer assemblages. Quaternary deposits have a thickness of $150 \mathrm{~m}$, and 250 $\mathrm{m}$ of Pliocene beds were cored.

The isolated Core 1 (sub-bottom depth $57.0-66.0 \mathrm{~m}$ ) yielded an upper Pleistocene foraminifer assemblage, which particularly comprises abundant and well-preserved Globorotalia truncatulinoides and Pulleniatina finalis. Core 2 still contained $G$. truncatulinoides and is assigned to the lowermost Pleistocene. Cores 3 to 29 contain Pliocene assemblages; the abundance of these specimens is irregular, varying from few to common, but never abundant. Their preservation is generally moderate, and broken specimens are not unfrequent. Planktonic foraminifers constitute between 80 and $98 \%$ of the foraminiferal assemblage, with an average of 85 to $90 \%$. Benthics are mainly miliolids and uvigerinids; nodosarids and rotalids are rare.

The Pliocene/Pleistocene boundary has been placed between Cores 2 and 3, taking into account (1) the first appearance of $G$. truncatulinoides in Core 3; (2) the rather good correlation of foraminifer assemblages from Cores 533A-3 and -4 with the well-dated uppermost Pliocene sequence that is represented in Hole 533 by Cores 38 to 41 .

The boundary between the upper Pliocene ( $=$ Pulleniatina obliquiloculata Zone, Stainforth et al., 1975) and the middle/lower Pliocene (= Globorotalia margaritae Zone) has been determined to be between Cores 14 and 15 , on the evidence of the LAD of G. margaritae (Sample 533A-15,CC).

Based on the continuing presence of $G$. margaritae and $G$. crassaformis, the whole section comprising Cores 15 to 29 has tentatively been assigned to the middle Pliocene.

The Pliocene assemblages in Hole 533A include Globorotalia crassaformis (common), G. multicamerata (rare), and Globigerinoides spp. (e.g., conglobatus, ruber, obliquus, and rare fistulosus). Globorotalia miocenica and Globorotalia tosaensis (always rare) first appear in Core 6, Sphaeroidinella dehiscens dehiscens in Core 8. Other significant datums are represented by LADs of Globoquadrina altispira (Sample 533A-7,CC), Globorotalia praemiocenica (533A-4,CC), Sphaeroidinellopsis subdehiscens, S. seminulina, and G. plesiotumida (533A-22,CC). Ranges of the principal species are given in Figure 27.

\section{Nannofossils}

A thick section of Quaternary through middle Pliocene muds was recovered at this site. Calcareous nannofossils are abundant to common and well preserved throughout the recovered section. Delicate genera such as Pontosphaera and Scyphosphaera occur in most samples. The changes in the overall abundance of nannofossils in the sediments is attributed to changes in detrital 


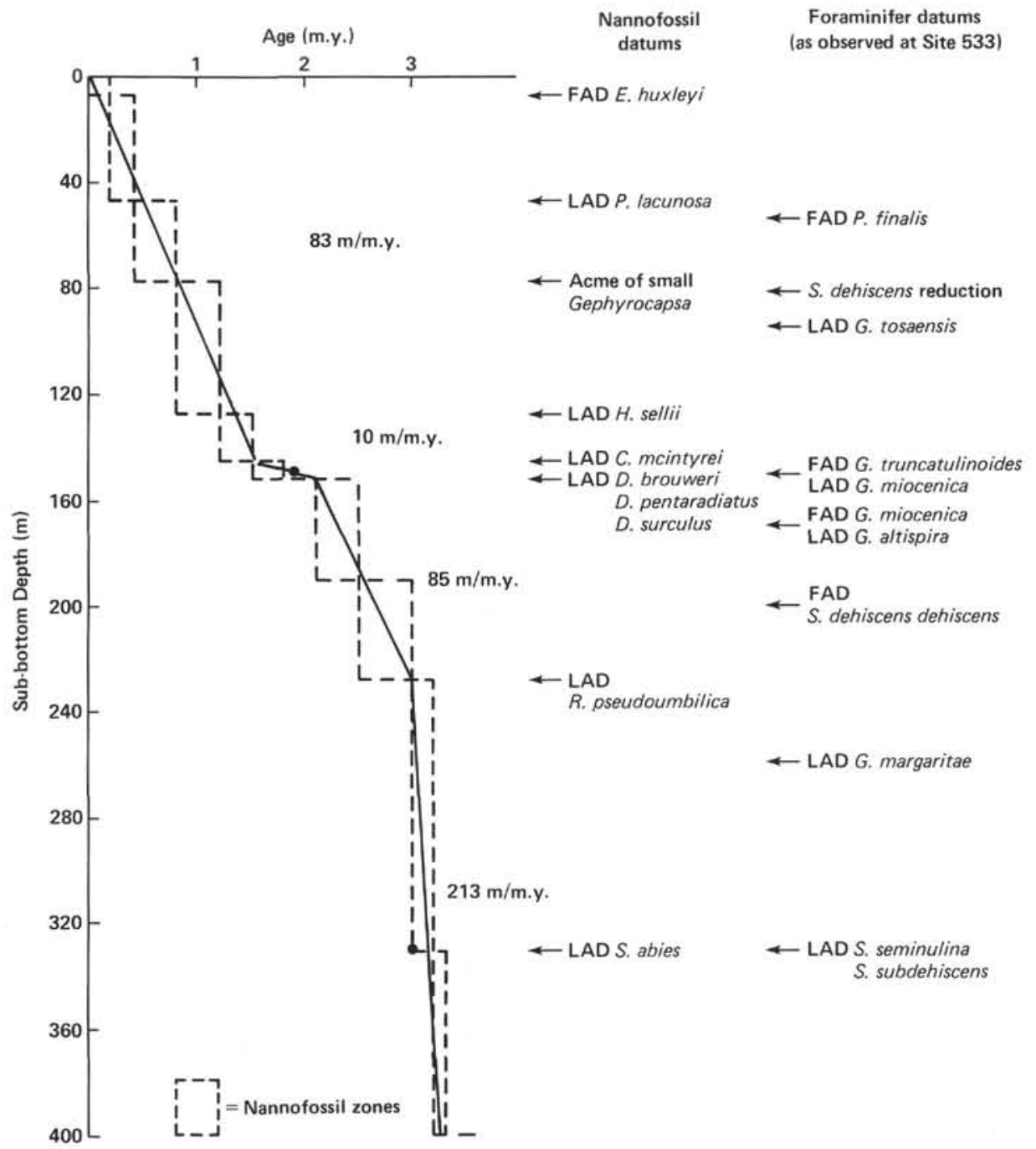

Figure 25. Rates of sedimentation at Site 533.

admixture rather than changes in the dissolution of carbonate. Nannofossil assemblages are diverse and show a tropical to subtropical aspect with Scyphosphaera ssp. in many samples. On the other hand, Coccolithus pelagicus, a cold-water form in the present oceans, occurs in the majority of the Quaternary and Pliocene samples, which might be indicative of some sediment transport by bottom currents to this site from higher latitudes.

Reworked nannofossils are very rare in the recovered cores (less than about one reworked specimen per $10^{4}$ to $10^{5}$ authochthonous forms). The majority of the reworked species are Upper Cretaceous. Very rare reworked Tertiary coccoliths occur in lower Pleistocene cores. Thus whatever the mechanism of emplacement of the hemipelagic muds at this site, very little reworking of considerably older material occurred.

The Quaternary section seems fairly complete, and the more detailed zonation of Gartner (1977) could be used. Only a limited number of samples have been studied, and changes in the exact position of 20 zonal boundaries after more careful study are anticipated. Table 2 summarizes zonal assignments and marker species and estimates of radiometric ages of the biostratigraphic boundaries.

The uppermost four cores are tentatively assigned to the Emiliania huxleyi Zone. However, verification of the marker species using the electron microscope is necessary before one can be certain about the presence and extent of this zone. Cores 5 to 13 belong to the Gephyrocapsa oceanica Zone. Coccolithus pelagicus is present, indicating colder water conditions or sediment transport from the north. Cores 14 to 20 belong to the Pseudoemiliania lacunosa Zone (sensu Gartner, 1977) and are characterized by abundant P. lacunosa, Gephyrocapsa caribbeanica, and common $G$. oceanica. Cores 21 through 31 are characterized by very abundant small Gephyrocapsa and are thus assigned to the small Gephyrocapsa Zone. Cores 32 through 35 belong to the Helicosphaera sellii Zone. They contain rare Helicosphaera sellii, common Pseudoemiliania lacunosa, and Gephyrocapsa caribbeanica. Cores 36, 37, and Section 1 of Core 38 contain assemblages that include Calcidiscus mcintyrei and Helicosphaera sellii but lack discoasters; this is characteristic for the Calcidiscus mcintyrei Zone 


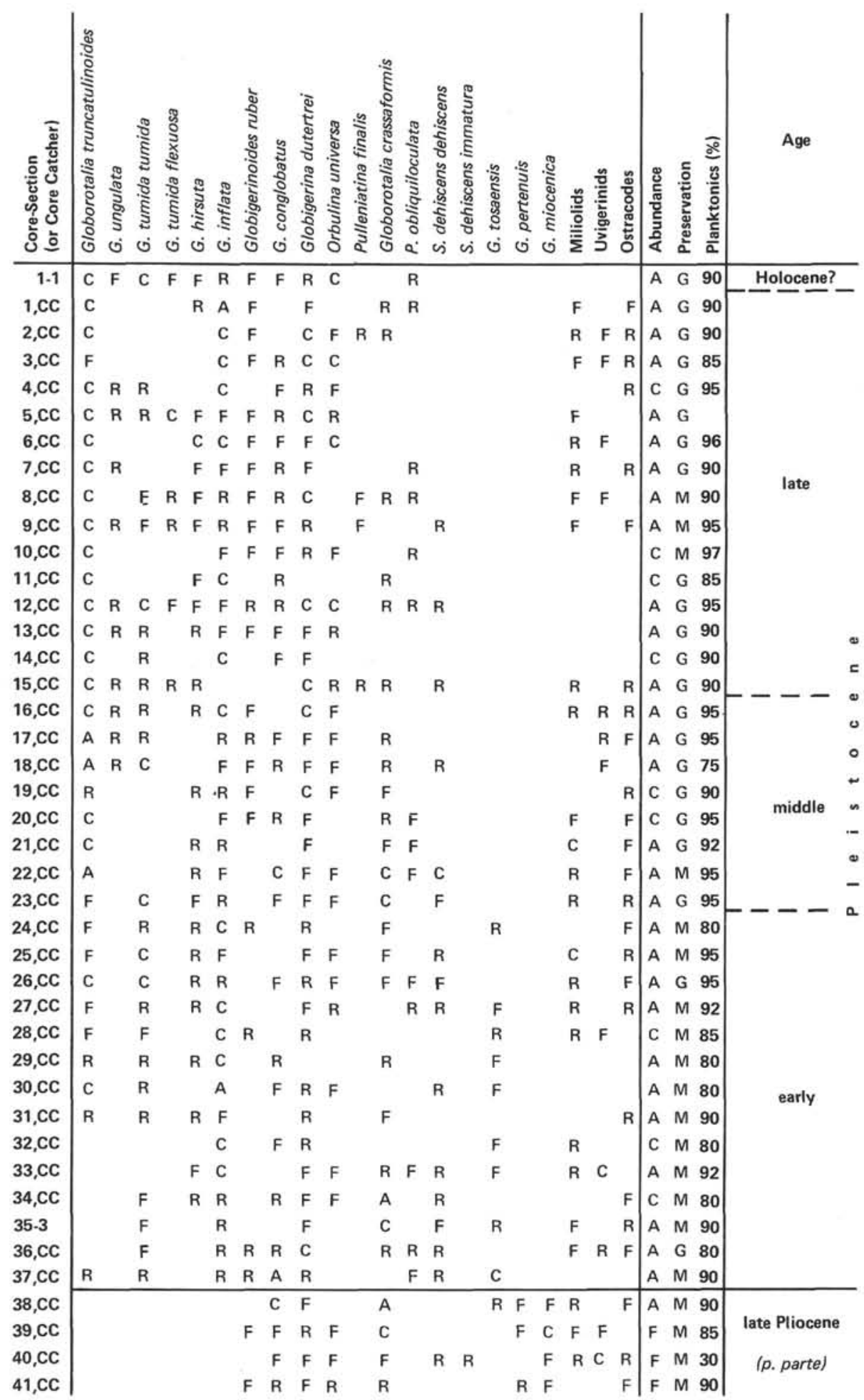

Figure 26. Distribution of foraminifers and ostracodes at Hole 533 (for explanation of symbols, see Fig. 27),

(sensu Gartner, 1977). The Pliocene/Pleistocene boundary is placed between Sections 1 and 2 of Core 38 .

Section 2 of Core 38 contains a few specimens of Discoaster brouweri and thus belongs to the upper Pliocene Discoaster brouweri Zone. Section 3 and the core catcher of Core 38 are assigned to the Discoaster pentaradiatus Zone. Cores 39 through 41 and Cores $533 \mathrm{~A}-4$ through
-7 belong to the Discoaster surculus zone. Cores 533A-8 through -11 contain few to rare specimens of Discoaster tamalis and are thus assigned to the Discoaster tamalis Zone.

All upper Pliocene zones are present, but the uppermost two Pliocene zones are unusually thin, considering the high sedimentation rate for the remainder of the sec- 


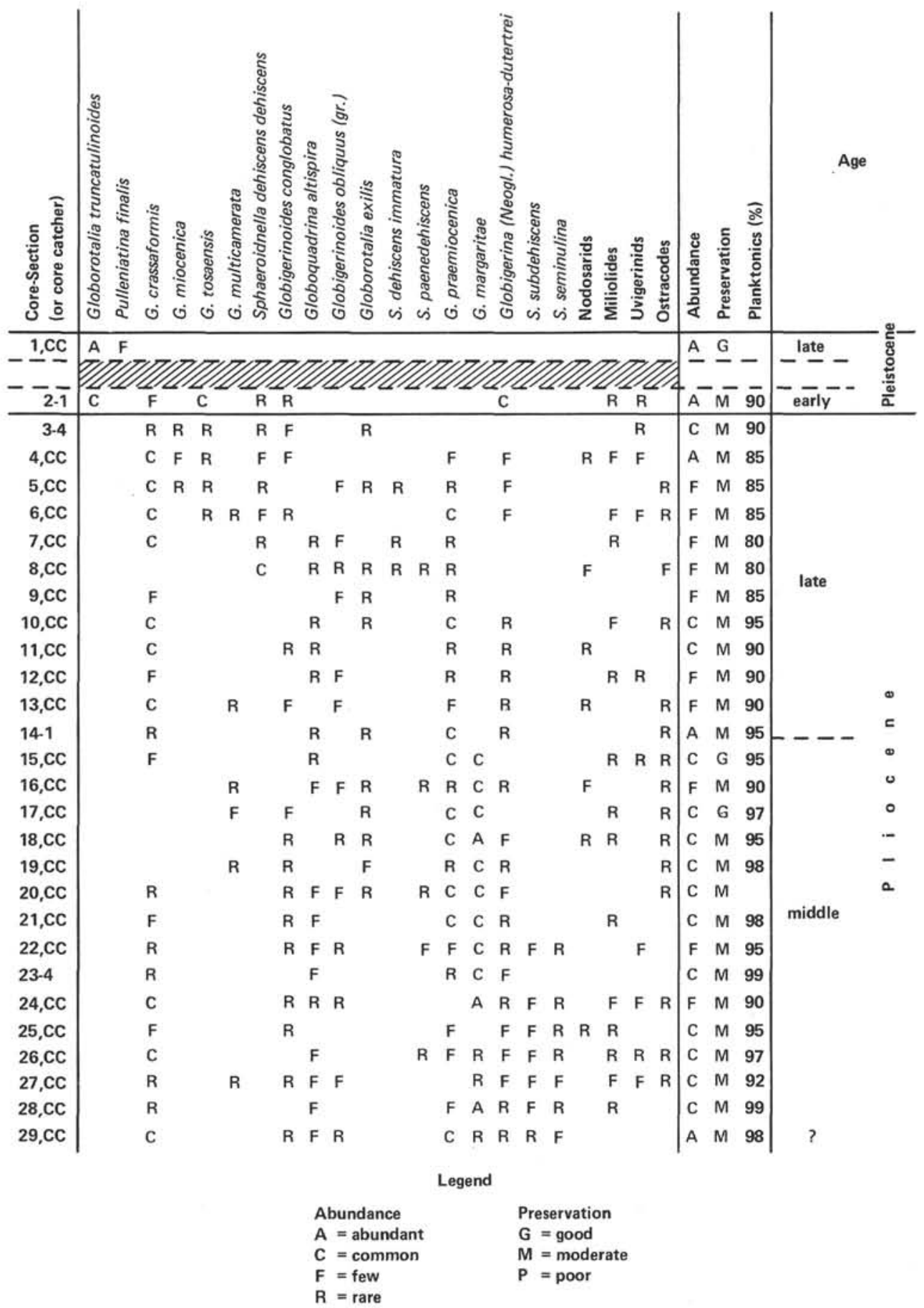

Figure 27. Distribution of foraminifers and ostracodes at Hole 533A.

tion at this site. This characteristic seems indicative of reduced sedimentation and possibly some erosion during the latest Pliocene.

Relatively small but well-developed specimens of $R e$ ticulofenestra pseudoumblica were observed in Cores 533A-12 through -22. Sphenolithus abies is not present in these cores, as it last occurs in Core 533A-23, where one also observes a marked increase in the size of Reticulofenestra pseudoumbilica. Discoaster asymmetricus is more abundant in Cores 533A-23 through -29; these cores are also assigned to the Reticulofenestra pseudoumbilica Zone, most possibly to the upper part of this zone; unfortunately the base of this zone was not reached, which makes geochronology more difficult to establish.

Both the Pliocene and Pleistocene sections at this site are very thick and quite complete; they should be studied in greater detail to detect a possible record of climatic fluctuations as well as evolutionary changes among various groups of nannofossils. 
Table 2. Site 533 nannoplankton.

\begin{tabular}{|c|c|c|c|c|}
\hline $\begin{array}{l}\text { Cores } \\
\text { (and section or } \\
\text { core catcher) }\end{array}$ & $\begin{array}{c}\text { Age } \\
(\mathrm{m} . \mathrm{y} .)\end{array}$ & Important species & Zone & Age \\
\hline $533-1-4$ & 0.2 & $\begin{array}{l}\text { Emiliania huxleyi ? (A) } \\
\text { Gephyrocapasa oceanica (A) } \\
\text { Coccolithus pelagicus (F) }\end{array}$ & $\begin{array}{l}\text { Emiliani } \\
\quad \text { huxleyi (?) }\end{array}$ & \multirow{6}{*}{ 密 } \\
\hline $533-5-13$ & 0.4 & $\begin{array}{l}\text { Gephyrocapsa oceanica (A) } \\
\text { G. caribbeanica }(\mathrm{A}) \\
\text { Coccolithus pelagicus (F) }\end{array}$ & $\begin{array}{c}\text { Gephyrocapsa } \\
\text { oceanica }\end{array}$ & \\
\hline $533-14-20$ & 0.8 & $\begin{array}{l}\text { Pseudoemiliania lacunosa (A) } \\
\text { Gephyrocapsa caribbeanica (A) } \\
\text { G. oceanica (C) } \\
\text { Coccolithus pelagicus (F) }\end{array}$ & $\begin{array}{l}\text { Pseudoemiliania } \\
\quad \text { Iacunosa } \\
\text { (sensu Gartner) }\end{array}$ & \\
\hline $533-21-31$ & 1.2 & $\begin{array}{l}\text { Small Gephyrocapsa (A) } \\
\text { Gephyrocapsa caribbeanica (C) } \\
\text { Pseudoemiliania lacunosa (A) }\end{array}$ & $\begin{array}{l}\text { small } \\
\quad \text { Gephyrocapsa }\end{array}$ & \\
\hline $533-32-35$ & 1.5 & $\begin{array}{l}\text { Pseudoemiliania lacunosa }(\mathrm{C}) \\
\text { Gephyrocapsa caribbeanica }(\mathrm{A}) \\
\text { Helicosphaera sellii }(\mathrm{R})\end{array}$ & $\begin{array}{l}\text { Helicosphaera } \\
\text { sellii }\end{array}$ & \\
\hline $533-36-38-1$ & 1.8 & $\begin{array}{l}\text { Pseudoemiliania lacunosa }(\mathrm{C}) \\
\text { Gephyrocapsa caribbeanica }(\mathrm{C}) \\
\text { Helicosphaera sellii }(\mathrm{R}) \\
\text { Calcidiscus mcintyrei }(\mathrm{R})\end{array}$ & $\begin{array}{l}\text { Calcidiscus } \\
\quad \text { mcintyrei } \\
\text { (sensu Gartner) }\end{array}$ & \\
\hline $533-38-2$ & 2.0 & $\begin{array}{l}\text { Discoaster brouweri }(\mathrm{F}) \\
\text { Pseudoemiliania lacunosa }(\mathrm{C}) \\
\text { Coccolithus pelagicus }(\mathrm{C})\end{array}$ & $\begin{array}{l}\text { Discoaster } \\
\quad \text { brouweri }\end{array}$ & \multirow{4}{*}{ 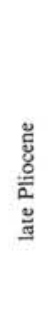 } \\
\hline $\begin{array}{l}533-38-3 \text { and } \\
533-38, \mathrm{CC}\end{array}$ & 2.1 & $\begin{array}{l}\text { Discoaster brouweri }(C) \\
\text { D. pentaradiatus }(\mathrm{F})\end{array}$ & $\begin{array}{l}\text { Discoaster } \\
\quad \text { pentaradiatus }\end{array}$ & \\
\hline $\begin{array}{l}533-39-41 \\
533 A-4-7\end{array}$ & 2.5 & $\begin{array}{l}\text { Discoaster surculus }(\mathrm{F}) \\
\text { D. pentaradiatus }(\mathrm{F}) \\
\text { D. brouweri }(\mathrm{C})\end{array}$ & $\begin{array}{l}\text { Discoaster } \\
\text { surculus }\end{array}$ & \\
\hline $533 A-8-11$ & 3.0 & $\begin{array}{l}\text { Discoaster tamalis }(\mathrm{F}) \\
\text { D. surculus }(\mathrm{F}) \\
\text { D. pentaradiatris }(\mathrm{F}) \\
\text { D. brouweri }\end{array}$ & $\begin{array}{r}\text { Discoaster } \\
\text { tamalis }\end{array}$ & \\
\hline $533 A-12-22$ & 3.2 & $\begin{array}{l}\text { Reticulofenestra pseudoumbilica } \\
\text { (small) }(\mathrm{C}) \\
\text { Discoaster surculus (F) } \\
\text { Discoaster variabilis (C) } \\
\text { Ceratolithus rugosus (R) }\end{array}$ & $\begin{array}{l}\text { Reticulofenestra } \\
\text { pseudoumbilica }\end{array}$ & \multirow{2}{*}{ 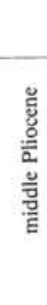 } \\
\hline $533 \mathrm{~A}-23-29$ & $3.3(?)$ & $\begin{array}{l}\text { Reticulofenestra pseudoumbilica } \\
\quad \text { (large) (C) } \\
\text { Sphenolithus abies (F) } \\
\text { Discoaster variabilis (C) } \\
\text { Ceratolithus rugosus (R) } \\
\text { Discoaster surculus (F) } \\
\text { Discoaster asymmetricus (F) }\end{array}$ & $\begin{array}{l}\text { Reticulofenestra } \\
\text { pseudoumbilica }\end{array}$ & \\
\hline
\end{tabular}

Note: $\mathrm{A}=$ abundant, $\mathrm{C}=$ common, $\mathrm{F}=$ few, and $\mathbf{R}=$ rare.

\section{SEDIMENTATION RATES}

Rates of sediment accumulation at Site 533 show considerable changes. A rate of about $83 \mathrm{~m} / \mathrm{m}$.y. is indicated for the Pleistocene. Nannofossils and planktonic foraminiferal stratigraphy show that during the late Pliocene, sediment accumulation slowed to a rate of 5 to $10 \mathrm{~m} / \mathrm{m} . \mathrm{y}$. Nannofossil data indicate sediment accumulation rates of $85 \mathrm{~m} / \mathrm{m}$.y. during the early part of the late Pliocene and a very high sedimentation rate of $213 \mathrm{~m} / \mathrm{m} . \mathrm{y}$. for the middle Pliocene. Based on foraminiferal data, sedimentation rates appear to be around $200 \mathrm{~m} / \mathrm{m}$.y. for the late and middle Pliocene. The results are graphically depicted in Figure 25 .

\section{ORGANIC GEOCHEMISTRY}

The shipboard organic geochemistry program consisted of five phases: (1) analyses of gases recovered by means of vacutainers from void spaces (gas pockets) in core liners; (2) headspace analyses of gases extracted from sediment samples; (3) pressure and volume measurements obtained upon the decomposition of suspected gas hydrates and subsequent analyses of the evolved gases; (4) analyses of gases obtained from the pressure core barrel during sequential reiease at different temperatures; and (5) collection of samples for further shorebased studies.

\section{Gas Analyses}

Hydrocarbon gases; methane $\left(C_{1}\right)$, ethane $\left(C_{2}\right)$, propane $\left(\mathrm{C}_{3}\right)$, iso- and normal butane (i- $\mathrm{C}_{4}$ and $\left.n-\mathrm{C}_{4}\right)$, isoand normal pentane (i- $\mathrm{C}_{5}$ and $n-\mathrm{C}_{5}$ ), and iso- and normal hexane (i- $\mathrm{C}_{6}$ and $n-\mathrm{C}_{6}$ ), were found in many of the samples from Site 533, with $C_{1}$ being at least three orders of magnitude higher in concentration than the other hydrocarbon gases. Two procedures were used for analysis. In the first procedure gases were recovered directly from gas pockets developed as sediment separated in the core liner due to gas expansion. These gas pockets were sampled by means of a hollow punch with a valve to prevent immediate gas release. After the punch penetrated the core liner, gas was vented through the valve into standard 20 -ml evacuated containers called vacutainers. The collected gases were analyzed by gas chromatography, and concentrations of $\mathrm{C}_{1}$ through $\mathrm{C}_{5}$ hydrocarbons and $\mathrm{CO}_{2}$ were determined (Table 3 ). Hydrocarbons larger than $\mathrm{C}_{5}$ could not be measured because of interfering compounds that are present in the vacutainers. The second procedure, described by Bernard et al., (1978) and modified by Kvenvolden and Redden (1980) involved extracting gases from segments of sediment core into a helium headspace and analyzing a portion of the headspace by gas chromatography (see the upcoming section on Laboratory Procedures). Concentrations of hydrocarbon gases $C_{1}$ through $C_{6}$ and $\mathrm{CO}_{2}$ were measured (Table 4).

Site 533 provided a unique opportunity to compare results from the two procedures. Sampling the gases in the core directly with vacutainers required that sufficient gas be present to cause gas pockets to form within the core liners. At a sub-bottom depth of about $25 \mathrm{~m}$ gas pockets were first noted, and between this depth and about $50 \mathrm{~m}$ three analyses by vacutainers were made (Table 3 ). $C_{1}$ through $C_{5}$ hydrocarbons were detected but the $C_{1}$ concentrations of less than $11 \%$ suggested that air contamination accounted for much of the remaining $89 \%$ of the gas. From a sediment depth of about $50 \mathrm{~m}$ to the bottom of the hole at $400 \mathrm{~m}$ gas pockets commonly occurred in most cores. $\mathrm{C}_{1}$ concentrations ranged from 47 to $99 \%$ (with two exceptions) in these pockets (Table 3). Because air contamination is always a possibility in the vacutainer sampling procedures, these $C_{1}$ concentrations represent minimum values. Higher molecular weight hydrocarbon gases$\mathrm{C}_{2}, \mathrm{C}_{3}, \mathrm{i}-\mathrm{C}_{4}, n-\mathrm{C}_{4}, \mathrm{i}-\mathrm{C}_{5}$, and $n-\mathrm{C}_{5}$-were generally present at much lower but still significant concentrations (Table 3). The amounts of these gases varied with depth but generally were higher in samples collected deeper in the core. Ratios of $C_{1} / C_{2}$ were high (averaging about 41,000 ) in gas recovered by vacutainer from intervals in the first $200 \mathrm{~m}$ of core. Below this depth, this ratio decreased to a minimum value of about 4000 at $400 \mathrm{~m}$ depth (Fig. 28A).

Headspace analyses provided a means of measuring the composition of gas extracted from the sediment at intervals down the core. Sampling did not depend on the 
Table 3. Analyses of gas in vacutainer samples taken from gas pockets in Site 533 cores.

\begin{tabular}{|c|c|c|c|c|c|c|c|c|c|c|}
\hline Core-section & $\begin{array}{l}\text { Approximate } \\
\text { sub-bottom } \\
\text { depth } \\
\text { (m) }\end{array}$ & $\begin{array}{l}C_{1} \\
(\%)\end{array}$ & $\underset{(\mathrm{ppm})}{\mathrm{C}_{2}}$ & $\begin{array}{c}\mathrm{C}_{3} \\
(\mathrm{ppm})\end{array}$ & $\begin{array}{c}\mathrm{i}-\mathrm{C}_{4} \\
(\mathrm{ppm})\end{array}$ & $\begin{array}{c}n \cdot \mathrm{C}_{4} \\
(\mathrm{ppm})\end{array}$ & $\begin{array}{l}\mathrm{i}-\mathrm{C}_{5} \\
(\mathrm{ppm})\end{array}$ & $\begin{array}{c}n-\mathrm{C}_{5} \\
(\mathrm{ppm})\end{array}$ & $C_{1} / C_{2}$ & $\begin{array}{l}\mathrm{CO}_{2} \\
(\%)\end{array}$ \\
\hline \multicolumn{11}{|l|}{ Hole 533} \\
\hline $9-1$ & 24.9 & 4 & 9 & 2.2 & 1.4 & 1.6 & 0.2 & - & 4,400 & 0.2 \\
\hline $9-2$ & 25.4 & 10 & 6 & 1.2 & 1.0 & 1.1 & 0.6 & - & 13,000 & 0.6 \\
\hline $11-1$ & 33.9 & 7 & 17 & 3.7 & 1.8 & 1.4 & 0.2 & - & 4,100 & 0.3 \\
\hline $15-2$ & 53.0 & 80 & 15 & 3.3 & 1.4 & 1.0 & - & - & 53,000 & 1.8 \\
\hline $16-3$ & 58.0 & 5 & 8 & 1.5 & 1.2 & 1.4 & - & - & 6,300 & 0.3 \\
\hline $17-2$ & 61.0 & 78 & 20 & 4.3 & 2.1 & 1.4 & - & - & 39,000 & 1.7 \\
\hline $20-1$ & 73.0 & 81 & 18 & 4.3 & 1.3 & 0.2 & 0.6 & 0.03 & 45,000 & 1.5 \\
\hline $21-1$ & 77.5 & 80 & 18 & 4.0 & 1.4 & 0.2 & 0.5 & 0.04 & 44,000 & 1.9 \\
\hline $22-1$ & 82.0 & 90 & 14 & 3.3 & 1.0 & 0.2 & 0.5 & 0.03 & 64,000 & 2.1 \\
\hline 23-1 & 86.5 & 89 & 16 & 3.7 & 1.0 & 0.2 & 0.5 & 0.03 & 56,000 & 1.1 \\
\hline $24-2$ & 92.6 & 72 & 12 & 3.0 & 1.0 & 0.2 & 0.4 & 0.04 & 60,000 & 1.3 \\
\hline $25-2$ & 97.0 & 72 & 17 & 4.3 & 1.4 & 0.4 & 0.4 & 0.04 & 42,000 & 1.3 \\
\hline 26-1 & 100.0 & 76 & 16 & 3.9 & 1.4 & 0.2 & 0.6 & 0.04 & 48,000 & 1.5 \\
\hline $27-2$ & 106.0 & 60 & 16 & 4.8 & 1.6 & 0.4 & 0.6 & 0.06 & 38,000 & 1.4 \\
\hline $28-3$ & 110.0 & 79 & 21 & 5.3 & 1.9 & 0.3 & 0.8 & 0.05 & 38,000 & 1.3 \\
\hline $29-1$ & 113.5 & 47 & 13 & 3.3 & 1.1 & 0.2 & 0.6 & 0.03 & 36,000 & 0.9 \\
\hline $30-2$ & 119.5 & 66 & 261 & 66.0 & 23.0 & 4.0 & 11.0 & 0.8 & 2,500 & 1.4 \\
\hline $31-2$ & 124.0 & 98 & 24 & 6.1 & 1.8 & 0.5 & 0.8 & 0.05 & 41,000 & 1.2 \\
\hline $32-1$ & 127.0 & 65 & 16 & 4.1 & 1.4 & 0.4 & 0.5 & - & 41,000 & 1.5 \\
\hline $33-1$ & 131.5 & 84 & 21 & 6.0 & 2.1 & 0.6 & 0.7 & 0.05 & 40,000 & 2.5 \\
\hline $34-1$ & 136.0 & 69 & 17 & 5.0 & 1.8 & 0.4 & 0.8 & 0.09 & 41,000 & 2.4 \\
\hline $37-1$ & 146.5 & 83 & 27 & 7.4 & 2.5 & 0.6 & 1.1 & 0.1 & 31,000 & 2.2 \\
\hline $38-2$ & 151.0 & 95 & 25 & 7.4 & 2.3 & 0.6 & 1.2 & 0.1 & 38,000 & 1.9 \\
\hline $40-2$ & 160.0 & 80 & 20 & 7.4 & 2.9 & 0.7 & 1.4 & 0.2 & 40,000 & 4.4 \\
\hline $41-2$ & 164.5 & 85 & 26 & 10.0 & 3.9 & 1.0 & 1.7 & 0.3 & 33,000 & 3.5 \\
\hline \multicolumn{11}{|l|}{ Hole $533 \mathrm{~A}$} \\
\hline $1-6$ & 64.5 & 56 & 18 & 4.0 & 0.5 & 0.2 & 0.7 & 0.04 & 31,000 & 1.8 \\
\hline $3-3$ & 155.0 & 63 & 15 & 4.4 & 1.7 & 0.7 & 1.5 & 0.2 & 42,000 & 2.5 \\
\hline $4-3$ & 157.5 & 62 & 19 & 6.5 & 2.1 & 0.6 & 1.1 & 0.2 & 32,000 & 2.7 \\
\hline $5-6$ & 169.0 & 67 & 17 & 15.3 & 1.6 & 0.4 & 1.1 & 0.07 & 39,000 & 1.8 \\
\hline $6-1$ & 171.0 & 7 & 1 & 0.6 & 0.2 & 0.07 & 0.7 & 0.02 & 54,000 & 0.5 \\
\hline $11-4$ & 223.0 & 70 & 53 & 5.5 & 3.2 & 0.7 & 2.9 & 0.2 & 13,000 & 4.7 \\
\hline $13-1$ & 237.5 & 63 & 29 & 0.6 & 0.6 & 0.05 & 0.6 & 0.05 & 22,000 & 1.7 \\
\hline $15-2$ & 258.0 & 74 & 44 & 3.5 & 1.6 & 0.4 & 2.2 & 0.1 & 17,000 & 3.8 \\
\hline $16-6$ & 273.5 & 71 & 41 & 11.0 & 3.5 & 1.2 & 5.3 & 0.4 & 17,000 & 5.8 \\
\hline $17-5$ & 281.5 & 77 & 43 & 17.0 & 4.8 & 1.7 & 2.3 & 0.5 & 18,000 & 9.3 \\
\hline $18-4$ & 289.5 & 82 & 103 & 8.5 & 3.7 & 1.1 & 4.6 & 0.4 & 8,000 & 7.8 \\
\hline $19-7$ & 303.5 & 84 & 77 & 9.1 & 2.7 & 1.0 & 3.3 & 0.3 & 11,000 & 4.3 \\
\hline $20-6$ & 312.0 & 76 & 122 & 3.0 & 3.7 & 0.3 & 1.2 & - & 6,200 & 5.2 \\
\hline $21-6$ & 321.0 & 81 & 75 & 13.0 & 3.3 & 1.3 & 3.5 & 0.4 & 11,000 & 9.4 \\
\hline $22-6$ & 330.5 & 48 & 70 & 9.1 & 2.0 & 1.2 & 2.7 & 0.4 & 6,900 & 4.6 \\
\hline $24-5$ & 347.0 & 70 & 64 & 8.3 & 1.7 & 0.9 & 2.6 & 0.3 & 11,000 & 6.4 \\
\hline $25-2$ & 353.0 & 69 & 82 & 4.9 & 2.1 & 0.5 & 1.4 & 0.2 & 8,400 & 6.2 \\
\hline $26-4$ & 365.5 & 54 & 141 & 9.9 & 4.2 & 1.2 & 2.8 & 0.6 & 3,800 & 6.2 \\
\hline $27-6$ & 378.0 & 69 & 147 & 7.3 & 2.8 & 1.2 & 1.7 & 0.5 & 4,700 & 5.6 \\
\hline 29.1 & 391.2 & 71 & 173 & 11.0 & 4.8 & 1.6 & 2.6 & 1.1 & 4,100 & 10.0 \\
\hline
\end{tabular}

Note: - indicates no data available.

formation of gas pockets, as required for the procedure in which vacutainers were used. Thus headspace analyses of core samples started near the sediment surface and continued downward to about $4000 \mathrm{~m}$ (Table 4). Concentrations of all gases were less than obtained from vacutainers because of the dilution in the helium headspace and the partitioning of gases between water and helium. Although $\mathrm{C}_{1} / \mathrm{C}_{2}$ ratios in headspaces are generally lower than the $C_{1} / C_{2}$ ratios in vacutainers, the general trends with depth of these ratios is the same. For example, a comparison of the $\mathrm{C}_{1} / \mathrm{C}_{2}$ ratios with depth resulting from the two procedures is shown in Figure 28A (vacutainers) and 28B (headspace). The correlation coefficient for the best-fit line in Figure 28A is 0.94 , whereas that for Figure 28B is 0.96 . These comparisons do not include the data for samples collected from very shallow sediments. $C_{1} / C_{2}$ ratios for these samples are anomalously low relative to ratios found for gases in deeper samples and likely reflect a preferential loss of $\mathrm{C}_{1}$ from the near-surface sediments.

The trend of decreasing $C_{1} / C_{2}$ ratios with depth at Site 533 follows the trends of this ratio observed at other
DSDP sites (Fig. 29). The high $C_{1} / C_{2}$ ratios in sediments at these sites suggest that biogenic rather than thermogenic processes have been responsible for the production of $C_{1}$ and possibly $C_{2}$. The decreasing $C_{1} / C_{2}$ ratios with depth probably result from early thermal diagenesis in which $C_{2}$ and other hydrocarbon gases increase with depth at a greater rate than does $C_{1}$. At Site 533 the concentrations of $\mathrm{C}_{2}$ through $\mathrm{C}_{6}$ hydrocarbons vary but usually are higher in deeper samples. In general, the iso-hydrocarbons ( $\mathrm{i}-\mathrm{C}_{4}, \mathrm{i}-\mathrm{C}_{5}$, and $\mathrm{i}-\mathrm{C}_{6}$ ) were more abundant than their respective normal isomers $(n$ $\mathrm{C}_{4}, n-\mathrm{C}_{5}$, and $n-\mathrm{C}_{6}$ ); however, the ratio of iso- to normal hydrocarbons tended to decrease with depth, especially near the bottom of the hole (533A). This decreasing ratio also reflects the result of early thermal diagenesis.

\section{Gas Hydrates}

A principal objective at this site was to attempt to recover samples of gas hydrate and to measure the pressure, volume, and composition of gas released upon hydrate decomposition. Two methods were employed. The first measured pressure and the second measured vol- 
Table 4. Analyses of gas in headspace resulting from extraction of sediment samples from Site 533 cores.

\begin{tabular}{|c|c|c|c|c|c|c|c|c|c|c|c|c|}
\hline Core-section & $\begin{array}{l}\text { Sub-bottom } \\
\text { depth } \\
\text { (m) }\end{array}$ & $\begin{array}{l}C_{1} \\
(\%)\end{array}$ & $\underset{(\mathrm{ppm})}{\mathrm{C}_{2}}$ & $\underset{(\mathrm{ppm})}{\mathrm{C}_{3}}$ & $\begin{array}{l}\mathrm{i}-\mathrm{C}_{4} \\
(\mathrm{ppm})\end{array}$ & $\begin{array}{c}n-C_{4} \\
(\mathrm{ppm})\end{array}$ & $\begin{array}{l}\mathrm{i}-\mathrm{C}_{5} \\
(\mathrm{ppm})\end{array}$ & $\begin{array}{c}n-C_{5} \\
(\mathrm{ppm})\end{array}$ & $\begin{array}{l}\mathrm{i}-\mathrm{C}_{6} \\
(\mathrm{ppm})\end{array}$ & $\begin{array}{c}n-\mathrm{C}_{6} \\
(\mathrm{ppm})\end{array}$ & $\mathrm{C}_{1} / \mathrm{C}_{2}$ & $\begin{array}{l}\mathrm{CO}_{2} \\
(\%)\end{array}$ \\
\hline \multicolumn{13}{|l|}{ Hole 533} \\
\hline $1-1$ & 1.5 & 0.005 & 0.03 & 0.03 & 0.04 & 0.06 & - & - & - & - & 1,700 & 0.27 \\
\hline $2-1$ & 3.5 & 0.005 & 0.03 & 0.02 & 0.02 & - & - & - & - & - & 1,900 & - \\
\hline $6-2$ & 14.3 & 0.005 & 0.08 & 0.06 & 0.01 & 0.02 & - & - & - & - & 600 & 0.05 \\
\hline $8-1$ & 21.6 & 4.1 & 1.6 & 0.4 & 0.2 & 0.02 & - & - & - & - & 6,000 & 0.26 \\
\hline $10-2$ & 32.3 & 9.7 & 2.9 & 0.9 & 0.3 & 0.07 & 0.02 & 0.02 & - & - & 34,000 & 0.58 \\
\hline $12-1$ & 39.8 & 14.0 & 3.5 & 0.9 & 0.3 & 0.03 & 0.06 & 0.04 & - & - & 40,000 & 0.91 \\
\hline $14-1$ & 48.4 & 10.0 & 3.6 & 1.1 & 0.4 & 0.07 & 0.04 & - & - & - & 28,000 & 0.60 \\
\hline $18-1$ & 65.4 & 9.9 & 3.3 & 1.0 & 0.4 & 0.1 & 0.09 & 0.01 & - & - & 30,000 & 0.53 \\
\hline $22-1$ & 83.4 & 4.9 & 2.1 & 0.8 & 0.4 & 0.1 & 0.1 & 0.03 & - & - & 23,000 & 0.65 \\
\hline $26-1$ & 100.5 & 4.6 & 2.3 & 0.8 & 0.4 & 0.09 & 0.01 & - & - & - & 20,000 & 0.60 \\
\hline $30-1$ & 119.4 & 4.5 & 2.9 & 1.5 & 1.0 & 0.3 & 0.4 & 0.06 & - & - & 16,000 & 0.77 \\
\hline $34-1$ & 137.4 & 2.9 & 1.3 & 0.6 & 0.4 & 0.1 & 0.2 & 0.06 & - & - & 22,000 & 0.66 \\
\hline $39, \mathrm{CC}$ & 158.5 & 1.5 & 1.1 & 0.8 & 0.6 & 0.3 & 0.6 & 0.3 & - & - & 14,000 & 0.43 \\
\hline $41-1$ & 164.5 & 1.5 & 1.5 & 1.5 & 1.3 & 0.6 & 1.2 & 0.4 & 0.9 & - & 10,000 & 0.85 \\
\hline \multicolumn{13}{|l|}{ Hole $533 \mathrm{~A}$} \\
\hline $3-2$ & 154.5 & 3.6 & 2.1 & 1.0 & 0.7 & 0.4 & 0.8 & 0.3 & - & - & 17,000 & 1.0 \\
\hline $4-2$ & 157.4 & 2.1 & 2.4 & 2.2 & 1.7 & 0.8 & 1.9 & 0.6 & 0.8 & - & 8,800 & 1.6 \\
\hline $8-2$ & 192.9 & 3.0 & 2.0 & 1.7 & 1.5 & 0.8 & 2.7 & 0.7 & 0.5 & 0.2 & 15,000 & 1.4 \\
\hline $10-6$ & 216.5 & 6.3 & 6.2 & 5.5 & 4.4 & 2.1 & 9.0 & 1.0 & 1.0 & - & 10,000 & 3.6 \\
\hline $13-1$ & 237.8 & 2.7 & 4.6 & 1.2 & 1.1 & 0.6 & 3.8 & 0.4 & 0.9 & - & 5,900 & 2.8 \\
\hline $16-4$ & 272.0 & 2.3 & 2.4 & 3.2 & 2.2 & 1.7 & 11.0 & 1.1 & 1.8 & 0.8 & 9,600 & 2.6 \\
\hline $18-6$ & 293.9 & 4.9 & 8.8 & 4.9 & 2.9 & 2.1 & 11.0 & 1.4 & 1.6 & 0.8 & 5,600 & 3.3 \\
\hline $20-2$ & 306.9 & 4.0 & 6.5 & 4.4 & 2.0 & 1.8 & 8.1 & 0.8 & 1.1 & 0.8 & 6,200 & 3.1 \\
\hline $22-6$ & 332.0 & 3.1 & 7.5 & 4.6 & 1.9 & 1.9 & 6.2 & 1.6 & 1.2 & - & 4,100 & 2.1 \\
\hline $24-5$ & 349.4 & 1.9 & 4.2 & 4.8 & 1.6 & 1.8 & 5.0 & 1.4 & 1.2 & 1.5 & 4,500 & 3.4 \\
\hline $26-3$ & 365.4 & 1.9 & 4.7 & 3.5 & 1.4 & 1.9 & 5.6 & 1.4 & 1.6 & - & 4,000 & 2.0 \\
\hline $29-3$ & 396.6 & 2.3 & 8.7 & 1.1 & 0.8 & 0.5 & 1.2 & 0.9 & 1.1 & 2.1 & 2,600 & 1.8 \\
\hline
\end{tabular}

Note: - indicates no data available.
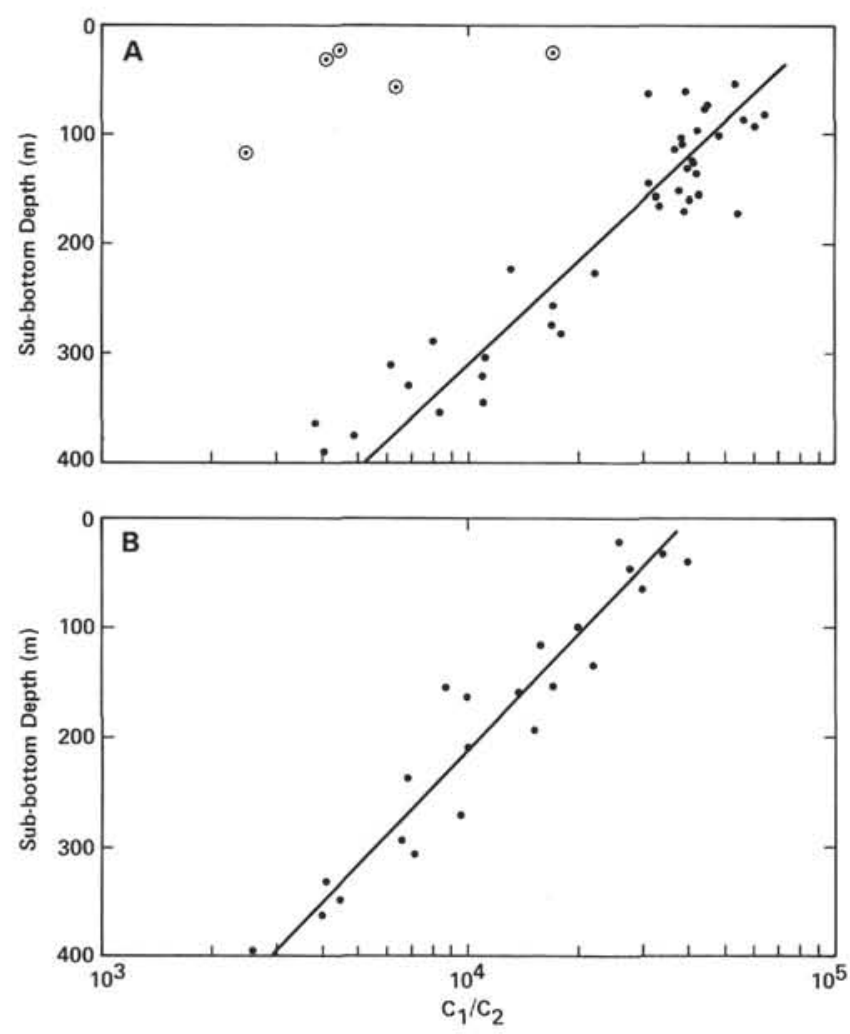

Figure 28. A. $C_{1} / C_{2}$ ratios at Site 533. (Gas from gas pockets within the core was removed by vacutainer. The contents of the vacutainer were analyzed by gas chromatography. Circled values were not included in calculations for the correlation coefficient.) B. $\mathrm{C}_{1} / \mathrm{C}_{2}$ ratios at Site 533. (Gas was extracted from sediment samples into a helium headspace; it was then removed and analyzed by gas chromatography.)

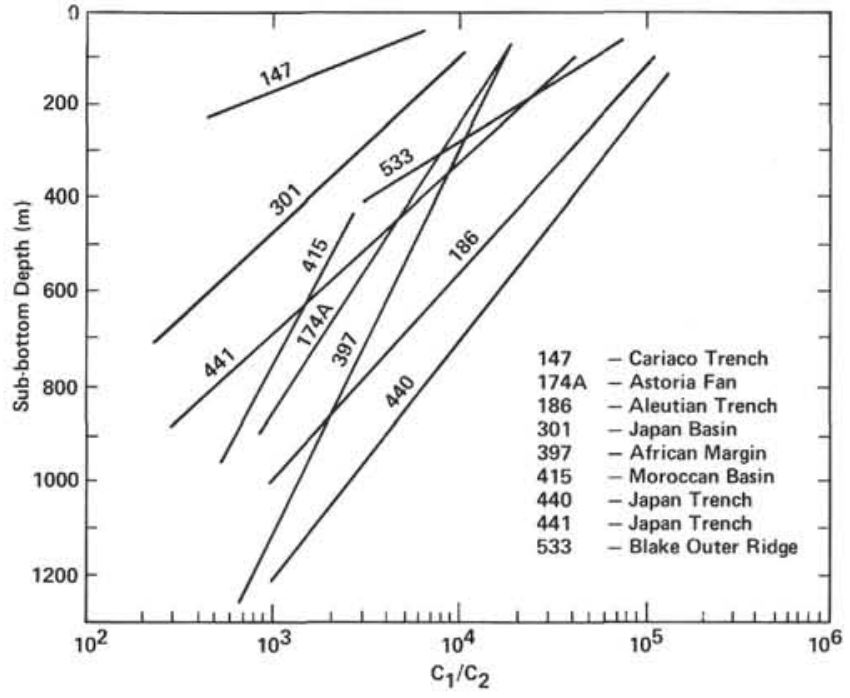

Figure 29. $C_{1} / C_{2}$ ratios at many DSDP sites, including Site 533. (Except for Site 533, data came from Claypool (1976), Whelan and Sato (1980), and Galimov et al. (1980).

ume. In the first method a sealed vessel of known volume was used to measure the pressure of gas released at $0^{\circ}$ and $70^{\circ} \mathrm{C}$, and samples of the released gas were recovered for analysis through a septum fitting. The second method involved a volumetric measuring device that measures the volume of gas released from a measured volume of hydrate. (Details of the gas hydrate work are discussed by Kvenvolden and Barnard, this volume).

Although gassy cores were recovered starting at a sediment depth of about $25 \mathrm{~m}$, direct evidence for gas 
hydrates was not observed until a depth of about $240 \mathrm{~m}$. When Core 13 of Hole 533A was first recovered, the vent-sub blew off as the core barrel was lowered to the deck. After Section 1 of Core 13 was opened, a thin layer of frothy icelike substance was observed (Fig. 24) at $26 \mathrm{~cm}$ from the top of the section. This sample was immediately used for pressure and volume measurements. The results from these measurements showed that upon decomposition the gas hydrate released a volume of gas approximately 20 times greater than the volume of pore fluid in the hydrate-containing sediment sample.

A sample of this gas was analyzed by gas chromatography; $\mathrm{C}_{1}$ was the major hydrocarbon present. Of particular interest was the observation that the relative concentrations of hydrocarbons larger than $\mathrm{i}-\mathrm{C}_{4}$, that is, $n$ $\mathrm{C}_{4}, \mathrm{i}-\mathrm{C}_{5}, n-\mathrm{C}_{5}, \mathrm{i}-\mathrm{C}_{6}$, and $n-\mathrm{C}_{6}$, were at least an order of magnitude lower than the relative concentrations of $\mathrm{C}_{3}$ and $\mathrm{i}-\mathrm{C}_{4}$ and almost three orders of magnitude smaller than the relative concentrations of $\mathrm{C}_{2}$. Because hydrocarbons larger than $\mathrm{i}-\mathrm{C}_{4}$ are too large to fit into the cages of the hydrate lattice (Hand et al., 1974), our results suggest that, indeed, gas from a gas hydrate had been sampled. The molecular distribution of this gas contrasts with the results generally obtained from vacutainer and headspace analyses of other gas samples, wherein no abrupt decrease in the concentrations of all hydrocarbon gases larger than $\mathrm{i}-\mathrm{C}_{4}$ was observed (Tables 3 and 4). Therefore, much of the gas removed from cores at Site 533 was probably not in hydrate form, because most of the gas samples analyzed from vacutainers and headspace showed the presence of the higher molecular-weight hydrocarbon gases (Tables 3 and 4). Thus the presence of gas hydrates, as indicated by the molecular distribution of hydrocarbon gases, may be masked by gases that are not in hydrate form except where gas hydrate is concentrated, as in the one sample just described.

\section{Pressure Core Barrel}

The pressure core barrel (PCB) had been designed and developed by the Deep Sea Drilling Project to be used to evaluate gas hydrate; Site 533 provided a unique opportunity for testing. A prototype PCB had been deployed twice previously (on Leg 44, Site 388 ) in attempts to demonstrate the presence of gas hydrates in marine sediments. Both attempts were unsuccessful, because the instrument failed to recover cores (Benson, Sheridan, et al., 1978, p. 33). The newly designed and constructed PCB recovered five cores from Hole 533A, three of which were at in situ pressure (Table 5). From three cores gas samples were taken. Portions of these gas samples were analyzed by gas chromatography, and the remaining gas was saved for detailed shore-based studies of molecular and isotopic composition. (Details of the PCB work are discussed by Kvenvolden et al., this volume.)

Drawn through a transfer manifold and high-pressure regulator into steel cylinders, $\mathrm{PCB}$ gas samples were collected at intervals after the PCB was brought on deck and immersed in an ice bath (Fig. 30). Initial high pres-
Table 5. Summary of pressure and core recovery by pressure core barrel at Site 533 .

\begin{tabular}{cccccc}
\hline PCB & Core & $\begin{array}{c}\text { Total } \\
\text { depth (m) }\end{array}$ & $\begin{array}{c}\text { Sub-bottom } \\
\text { depth (m) }\end{array}$ & $\begin{array}{c}\text { Recovery } \\
(\mathrm{m})\end{array}$ & $\begin{array}{c}\text { Pressure } \\
(\mathrm{MPa})\end{array}$ \\
\hline 1 & 3 & 3344 & 155 & 6.4 & 27.5 \\
2 & 14 & 3439 & 255 & $1.6^{\mathrm{a}}$ & 0 \\
3 & 23 & 3526 & 340 & 6.1 & 32.3 \\
4 & 26 & 3553 & 369 & 6.1 & 10.3 \\
5 & 29 & 3583 & 399 & 6.2 & 30.2 \\
\hline
\end{tabular}

${ }^{a}$ Unpressurized.

sures were immediately reduced to approximately 6 $\mathrm{MPa}$ upon drawing the first sample, due to the release of hydrostatic pressure. Core 533A-3 (PCB 1) contained a slurry of drilling fluids and cuttings rather than a sediment core and was degassed, but no samples were collected for further study. PCB 2 (Core 533A-14) closed correctly but failed to retain in situ pressure because of a missing plug. PCB 3 (Core 533A-23) functioned properly, and gas samples were drawn at timed intervals. PCB 4 (Core 533A-26) was degassed into one cylinder, immediately vented, opened, and inspected for the presence of gas-hydrate solids. None were found. PCB 5 (Core 533A-29) also operated correctly, and gas samples were collected at timed intervals. Only PCB 5 was degassed at two temperatures $\left(10^{\circ} \mathrm{C}\right.$ and $\left.29^{\circ} \mathrm{C}\right)$, measured at a port at the upper end of the tool. Figure 31 shows the degassing curve for PCB 5. For PCBs 1, 3, and 5, pressures were found to rise after each sample was collected, but the pressure did not return to previous levels. Gas compositions of sequential aliquots from both $\mathrm{PCB} 3$ and 5 varied in similar fashion. $C_{1} / C_{2}$ ratios were relatively constant through the duration of the degassing, but the $\mathrm{C}_{3}$ through $\mathrm{C}_{6}$ hydrocarbons increased fourfold.

\section{LABORATORY PROCEDURES}

\section{Headspace Analysis}

For each analysis a whole core segment of sediment $5 \mathrm{~cm}$ long $\left(\simeq 170 \mathrm{~cm}^{3}\right)$ was extruded from the core liner into a double-friction seal can $\left(1\right.$ pint $\simeq 480 \mathrm{~cm}^{3}$ ) that had been prepared with two septa-covered holes near the top. The can was filled with helium-purged (degassed) seawater, and a $100-\mathrm{ml}$ headspace was established by removing water from the can. The can was sealed with a lid, and the headspace was purged through the septa with helium for $5 \mathrm{~min}$. Gases from the sediment were equilibrated with the headspace gas by shaking the can vigorously for $10 \mathrm{~min}$. Portions of the resulting headspace gas mixtures were analyzed by gas chromatography. Concentrations of hydrocarbon gases $\mathrm{C}_{1}$ through $\mathrm{C}_{6}$ and $\mathrm{CO}_{2}$ were measured. Concentrations of $\mathrm{C}_{4}$ and $\mathrm{CO}_{2}$ are reported as volume percent (\%) of the gas mixture. Concentrations of $\mathrm{C}_{2}$ through $\mathrm{C}_{6}$ hydrocarbons are reported as parts per million (ppm) by volume of the gas mixture.

\section{Gas Chromatography}

$\mathrm{C}_{1}$ and $\mathrm{CO}_{2}$ were analyzed on a Carle Model 800 gas chromatograph (thermal conductivity detector) utilizing a $1 / 8 \mathrm{in} . \times 5 \mathrm{ft}$. column, packed with $8 \%$ carbowax 1540 on $90-100$ mesh Anachrom ABS, operated isothermally at $40^{\circ} \mathrm{C}$. Sample size was $250 \mu \mathrm{l}$ of gas recovered from vacutainers or the headspace of the cans. Areas of peaks on chromatograms were measured by a CSI Model 38 Integrator, and from these areas concentrations were calculated.

$\mathrm{C}_{2}$ through $\mathrm{C}_{6}$ hydrocarbons were analyzed on a Hewlett-Packard $5711 \mathrm{~A}$ gas chromatograph equipped with dual flame ionization detectors. Analyses were carried out on a 1/8 in. $\times 4 \mathrm{ft}$. column, packed with 40-100 mesh Spherosil attached to a $1 / 8 \mathrm{in} . \times 12 \mathrm{ft}$. column 


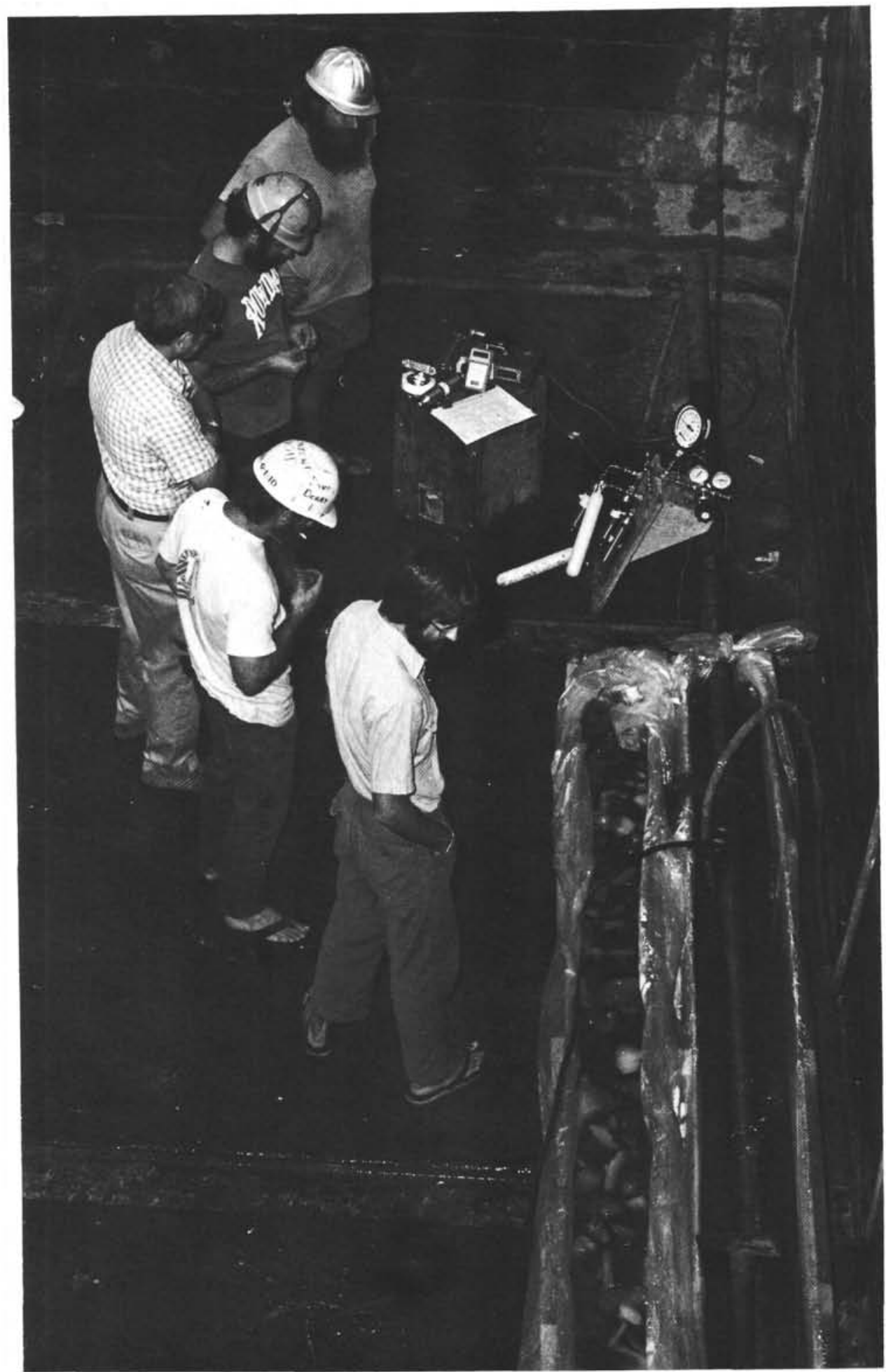

Figure 30. Pressure core barrel in bath. (Attached to the tool is the gas sampling manifold; pressure and temperature readouts are located on top of box.)

packed with $20 \%$ OV101 on 100-110 mesh Anakrom AS. Temperature of the columns was programmed from $60^{\circ}$ to $200^{\circ} \mathrm{C}$ at $8^{\circ} / \mathrm{min}$. A $5-\mathrm{ml}$ gas sample, obtained from either a vacutainer or headspace of a can, was introduced for chromatography through a septum into a chilled $1 / 8$ in. $\times 8$ in. loop, packed with $60-80$ mesh activated alumina (F-1), attached to an 8 port, 2-way sampling valve through which helium flows. The loop was cooled to $\sim-70^{\circ} \mathrm{C}$ in a refrigerated bath of iso- propanol. After a 2-min. wait, during which time $C_{1}$ and air were removed, the helium flow was interrupted, and the sample loop was heated for $1 \mathrm{~min}$. in a water bath at $\sim 90^{\circ} \mathrm{C}$. Then the sampling valve was opened, allowing the gas mixture containing $C_{2}$ to $C_{6}$ hydrocarbons to enter the gas chromatograph. Peak areas representing the various hydrocarbon gases were measured by a CSI Model 38 Integrator, and concentrations were calculated from these integrated areas. 


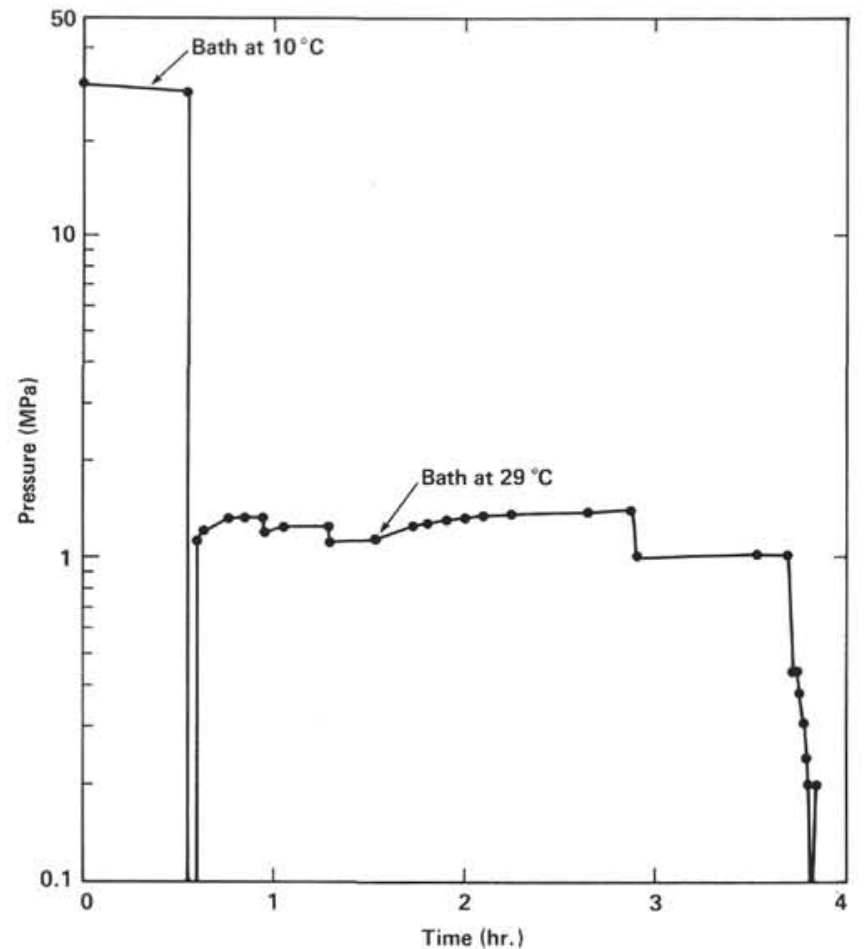

Figure 31. Pressure release versus time for pressure core barrel (PCB) 5 at Site 533.

\section{INORGANIC GEOCHEMISTRY}

An extensive interstitial water sampling program was undertaken for Holes 533 and $533 \mathrm{~A}$ in order to study the effects of high sedimentation rates $\left(>10 \mathrm{~cm} / 10^{3}\right.$ yr.), rapid sulfate reduction, and widespread production of biogenic methane during sediment diagenesis. Data for $\mathrm{pH}$, alkalinity, salinity, chlorinity, calcium, and magnesium were obtained by standard DSDP methods (see Explanatory Notes, this volume) and are presented in Table 6. Figures 32, 33, and 34 show these data plotted against sub-bottom depth. Several significant trends can be observed. Calcium declines from $10 \mathrm{mmol} / \mathrm{l}$ at the sediment/water interface to only $2 \mathrm{mmol} / \mathrm{l}$ in the first 20 $\mathrm{m}$, magnesium declines in the same interval by about 15 $\mathrm{mmol} / \mathrm{l}$, almost twice as much as calcium, and alkalinity increases to $25 \mathrm{meq} / \mathrm{l}$. These sharp initial changes, along with a $2 \%$ decrease in salinity, and probably due to rapid bacterial sulfate reduction with concomitant precipitation of carbonates and iron sulfides. One or two percent pyrite is observed throughout the length of the holes at Site 533. Low interstitial water pHs of 7.4 to 7.7 in this 20 - $\mathrm{m}$ interval can be explained by the acidity released during these reactions:

$$
\begin{gathered}
2 \mathrm{Ca}^{++}+\mathrm{SO}_{4}=+2 \text { ' } \mathrm{CH}_{2} \text { " } \rightarrow 2 \mathrm{CaCO}_{3}+\mathrm{HS}^{-}-3 \mathrm{H}^{+} \\
\text {and } \\
\mathrm{HS}^{-}+\mathrm{Fe}^{+2}+\mathrm{S}^{\circ} \rightarrow \mathrm{FeS}_{2} \text { (pyrite) }+\mathrm{M}^{+}
\end{gathered}
$$

\begin{tabular}{|c|c|c|c|c|c|c|c|}
\hline $\begin{array}{l}\text { Sample } \\
\text { (interval in } \mathrm{cm} \text { ) }\end{array}$ & $\begin{array}{l}\text { Sub-bottom } \\
\text { depth } \\
\text { (m) }\end{array}$ & $\mathrm{pH}$ & $\begin{array}{c}\text { Alkalinity } \\
\text { (meq/l) }\end{array}$ & $\begin{array}{c}\text { Salinity } \\
(\%)\end{array}$ & $\begin{array}{l}\text { Calcium } \\
(\mathrm{mmol} / \mathrm{l})\end{array}$ & $\begin{array}{c}\text { Magnesium } \\
(\mathrm{mmol} / \mathrm{l})\end{array}$ & $\begin{array}{c}\text { Chlorinity } \\
(\%)\end{array}$ \\
\hline IAPSO & & 7.467 & 2.426 & 35.20 & 10.55 & 53.99 & 19.378 \\
\hline SSW & & 8.247 & 2.422 & 36.47 & 10.95 & 55.53 & 20.09 \\
\hline \multicolumn{8}{|l|}{ Hole 533} \\
\hline $1-1,135-140$ & $1.35-1.40$ & 7.389 & 8.493 & 35.04 & 8.672 & 56.75 & 19.31 \\
\hline $2-1,75-80$ & $3.45-3.50$ & 7.583 & 11.879 & 34.76 & 7.266 & 49.15 & 19.43 \\
\hline $5-1,140-45$ & $9.80-9.85$ & 7.474 & 18.476 & 33.83 & 3.857 & 46.89 & 19.50 \\
\hline $6-2,145-150$ & $14.35-14.40$ & 7.619 & 24.610 & 33.17 & 2.323 & 43.18 & 19.46 \\
\hline $7-2,145-150$ & $18.85-18.90$ & 7.734 & 26.376 & 33.11 & 2.024 & 42.52 & 19.19 \\
\hline $8-1,140-145$ & $21.80-21.85$ & 7.674 & 26.516 & 33.28 & 2.216 & 41.71 & 19.53 \\
\hline $9-2,140-145$ & $27.80-27.85$ & 7.586 & 26.692 & 33.22 & 2.014 & 40.80 & 19.53 \\
\hline $10-2,140-145$ & $32.30-32.35$ & 8.132 & 25.552 & 33.22 & 1.374 & 38.58 & 19.53 \\
\hline $11-2,140-145$ & $36.80-36.85$ & 7.747 & 27.444 & 33.44 & 2.152 & 38.58 & 19.50 \\
\hline $12-1,140-145$ & $39.80-39.85$ & 7.586 & 25.018 & 33.55 & 1.891 & 39.27 & 19.55 \\
\hline $13-2,140-150$ & $45.80-45.90$ & 7.854 & 25.532 & 33.17 & 1.569 & 37.48 & 19.31 \\
\hline $14-1,14-150$ & $48.45-48.50$ & 7.878 & 24.636 & 33.39 & 2.041 & 36.65 & 19.58 \\
\hline $16-2,145-150$ & $57.95-58.00$ & 8.055 & 24.612 & 32.89 & 1.654 & 33.92 & 19.39 \\
\hline $18-1,140-150$ & $65.40-65.50$ & 8.001 & 25.612 & 33.11 & 1.912 & 33.90 & 19.41 \\
\hline $20-2,140-150$ & $75.90-76.00$ & 7.813 & 24.932 & 33.28 & 2.149 & 34.37 & 19.34 \\
\hline $22-1,140-150$ & $83.40-83.50$ & 7.828 & 23.018 & 32.78 & 1.740 & 32.34 & 19.24 \\
\hline $24-1,140-150$ & $92.40-92.50$ & 7.825 & 23.710 & 32.67 & 1.859 & 29.70 & 19.24 \\
\hline $26-2,140-150$ & $101.50-101.60$ & 7.745 & 22.398 & 32.67 & 1.898 & 27.75 & 18.98 \\
\hline $28-2,140-150$ & $111.90-112.00$ & 7.926 & 23.218 & 32.51 & 2.104 & 24.84 & 18.84 \\
\hline $30-1,140-150$ & $119.90-120.00$ & 7.820 & 25.548 & 32.62 & 2.278 & 25.33 & 18.93 \\
\hline $32-2,140-150$ & $129.90-138.00$ & 7.943 & 25.286 & 32.67 & 1.605 & 22.34 & 18.98 \\
\hline $34-1,140-150$ & $137.40-137.50$ & 7.932 & 27.204 & 32.78 & 1.432 & 22.93 & 18.91 \\
\hline $37-1,140-150$ & $147.90-148.00$ & 7.849 & 27.068 & 32.78 & 1.345 & 22.78 & 18.88 \\
\hline $40-1,140-150$ & $159.80-160.00$ & 7.946 & 32.816 & 32.89 & 1.866 & 22.68 & 18.74 \\
\hline \multicolumn{8}{|l|}{ Hole $533 \mathrm{~A}$} \\
\hline $3-2,146-150$ & $154.90-155.00$ & 7.538 & 26.789 & 33.83 & 3.765 & 28.72 & 19.21 \\
\hline $4-2,140-150$ & $157.40-157.50$ & 7.574 & 35.236 & 33.72 & 3.699 & 28.43 & 19.07 \\
\hline $8-2,140-150$ & $192.90-193.00$ & 7.450 & 68.634 & 34.10 & 3.984 & 27.47 & 18.70 \\
\hline $10-6,5-15$ & $218.05-218.15$ & 7.248 & 70.859 & 34.43 & 5.056 & 27.93 & 18.65 \\
\hline $13-4,135-150$ & $243.35-243.50$ & 7.544 & 48.344 & 33.229 & 4.256 & 24.58 & 18.07 \\
\hline $15-1,140-150$ & $257.90-258.00$ & 7.550 & 40.772 & 32.40 & 4.535 & 25.01 & 17.95 \\
\hline $16-4,135-145$ & $271.85-271.95$ & 7.200 & 56.002 & 34.38 & 4.793 & 24.57 & 18.49 \\
\hline $18-6,140-150$ & $293.90-294.00$ & 7.548 & 48.160 & 31.57 & 31.213 & 19.24 & 17.21 \\
\hline $20-2,140-150$ & $306.90-307.00$ & 7.450 & 53.700 & 33.88 & 4.744 & 22.13 & 18.34 \\
\hline $22-6,135-145$ & $331.84-331.95$ & 7.628 & 42,404 & 32.29 & 3.429 & 21.14 & 17.66 \\
\hline $24-5,140-150$ & $349.40-349.50$ & 7.513 & 48.234 & 33.11 & 3.795 & 19.95 & 17.93 \\
\hline $26-3,140-150$ & $365.40-365.50$ & 7.494 & 49.082 & 33.22 & 3.968 & 20.49 & 18.34 \\
\hline $29-3,140-150$ & $395.60-395.70$ & 7.236 & 41.028 & 33.33 & 5.089 & 22.19 & 18.37 \\
\hline
\end{tabular}

Table 6. Summary of shipboard inorganic geochemical data. 


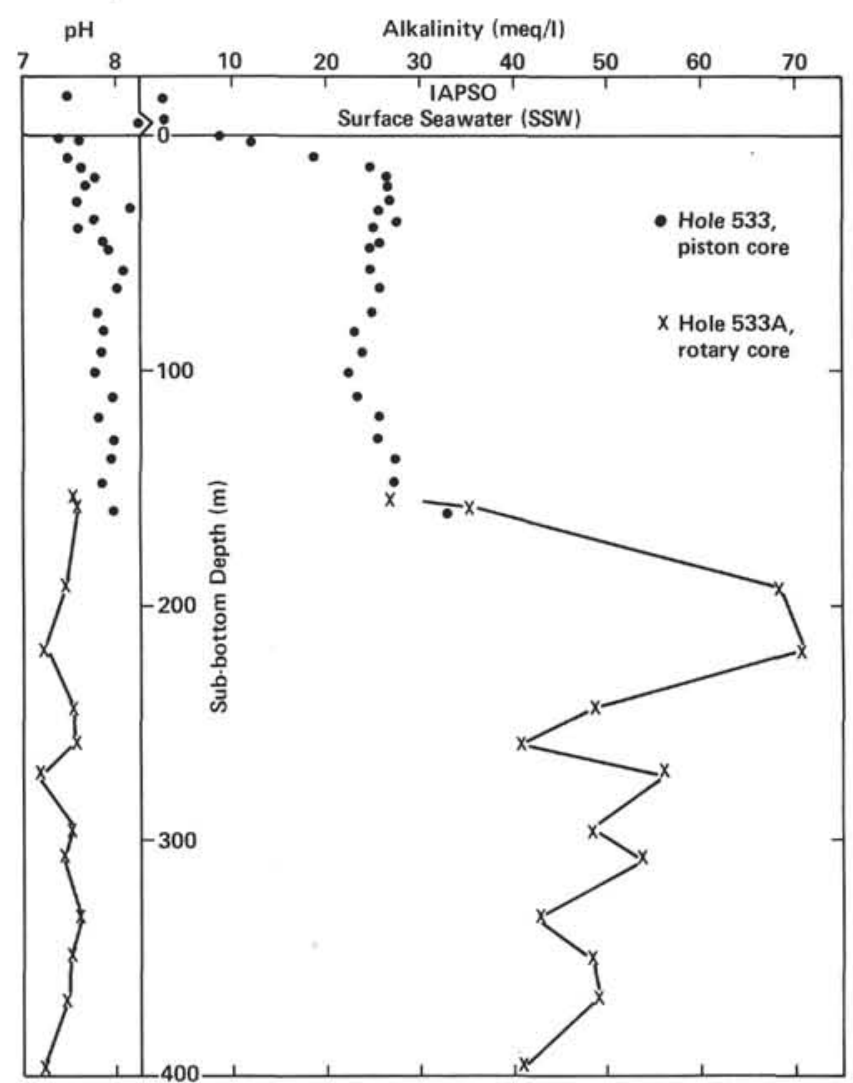

Figure 32. Alkalinity (meq/l) versus depth in sediment at Site 533.

Rapid and almost complete removal of sulfate in the first $20 \mathrm{~m}$ of sediment was observed at nearby Site 102, Leg 11, on the Blake Outer Ridge (Sayles et al., 1972).

Below $20 \mathrm{~m}$ to a sub-bottom depth of $150 \mathrm{~m}$ at the unconformable contact between Pliocene and Pleistocene sediments, calcium and alkalinity remain virtually constant at $2 \mathrm{mmol} / 1$ and $25 \mathrm{meq} / 1$, respectively. During this interval $\mathrm{pH}$ is also remarkably constant, varying between 7.8 and 8.0. Magnesium, however, continues to decrease to about $23 \mathrm{meq} / \mathrm{l}$. If this almost linear decline reflects a steady-state diffusion profile, then a likely sink for $\mathrm{Mg}$ exists in the sediments between 130 and $160 \mathrm{~m}$. Alternatively, authigenic glauconite and dolomite have been observed throughout this interval and could be responsible for a gradual $\mathrm{Mg}$ uptake down to $130 \mathrm{~m}$.

Mismatch of the chemical profiles between overlapping portions of Holes 533 and 533A (at approximately $150 \mathrm{~m}$ ) appears attributable to a slight amount of seawater contamination related to the switch from piston- to rotary-coring techniques. The fact that below $150 \mathrm{~m}$ calcium and magnesium show little variation implies that sample contamination is small and has not produced any spurious trends. Despite the monotony of the calcium and magnesium profiles, however, alkalinity, chlorinity, and salinity vary considerably and suggest that significant diagenesis is occurring in the Pliocene section. Just beneath the Pliocene/Pleistocene unconformity, alkalinity increases rapidly to a maximum of 70 $\mathrm{meq} / \mathrm{l}$ at $200 \mathrm{~m}$. The origin of this maximum is, at the moment, unclear. Alkalinity values remain above 40

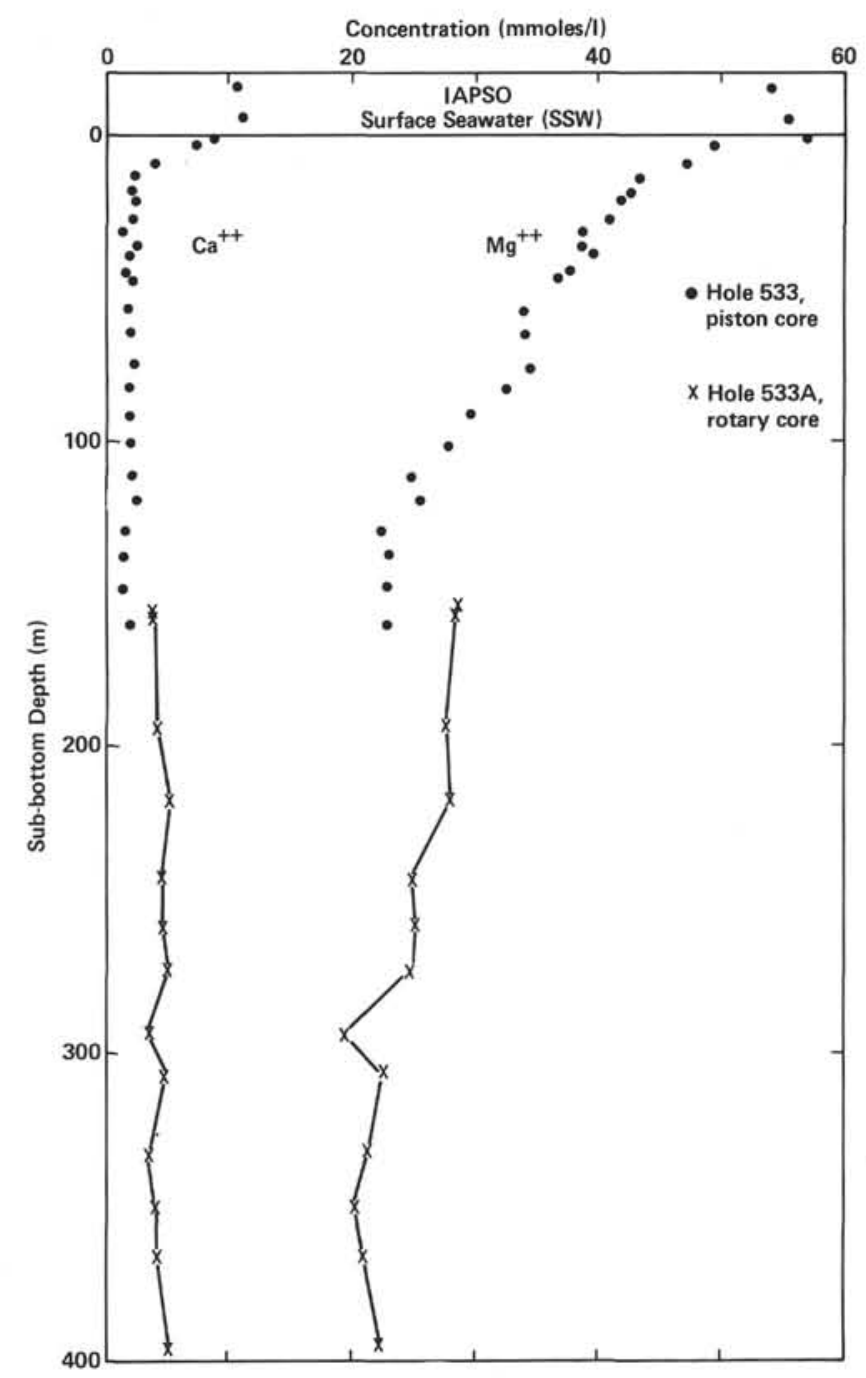

Figure 33. Concentrations of $\mathrm{Ca}^{++}$and $\mathrm{Mg}^{++}$(mmol/l) versus depth in sediment at Site 533 .

meq/l down to the bottom of the hole at $400 \mathrm{~m}$ and are highly variable, indicating the presence of strong concentration gradients. Such gradients could presumably only be maintained by zones of intense sediment alteration. Indeed, calcite replacing terrigenous silicates and the presence of carbonate concretion zones are observed in these sediments. In addition, evidence for gas hydrates was observed in the interval from 200 to $400 \mathrm{~m}$. The relationship between the formation of gas hydrates and the observed alkalinity behavior is, however, not yet apparent.

Chlorinity and salinity in the Pliocene section appear to display a minimum at $294 \mathrm{~m}$. A chloride minimum was also observed at Site 102, Leg 11 (Sayles et al., 1972), where values of $18.15 \%$ chloride and $30.0 \%$ salinity were found at about $400 \mathrm{~m}$ depth in the middle Pliocene sediments. The minimum discovered at the present site occurs in middle Pliocene sediments of similar lithology but is lower in magnitude $(17.2 \%$ minimum chlorinity) and somewhat less well-defined. Two points with "anomalously" high chlorinities and salinities occur at 272 and $307 \mathrm{~m}$ within this generally minimum re- 


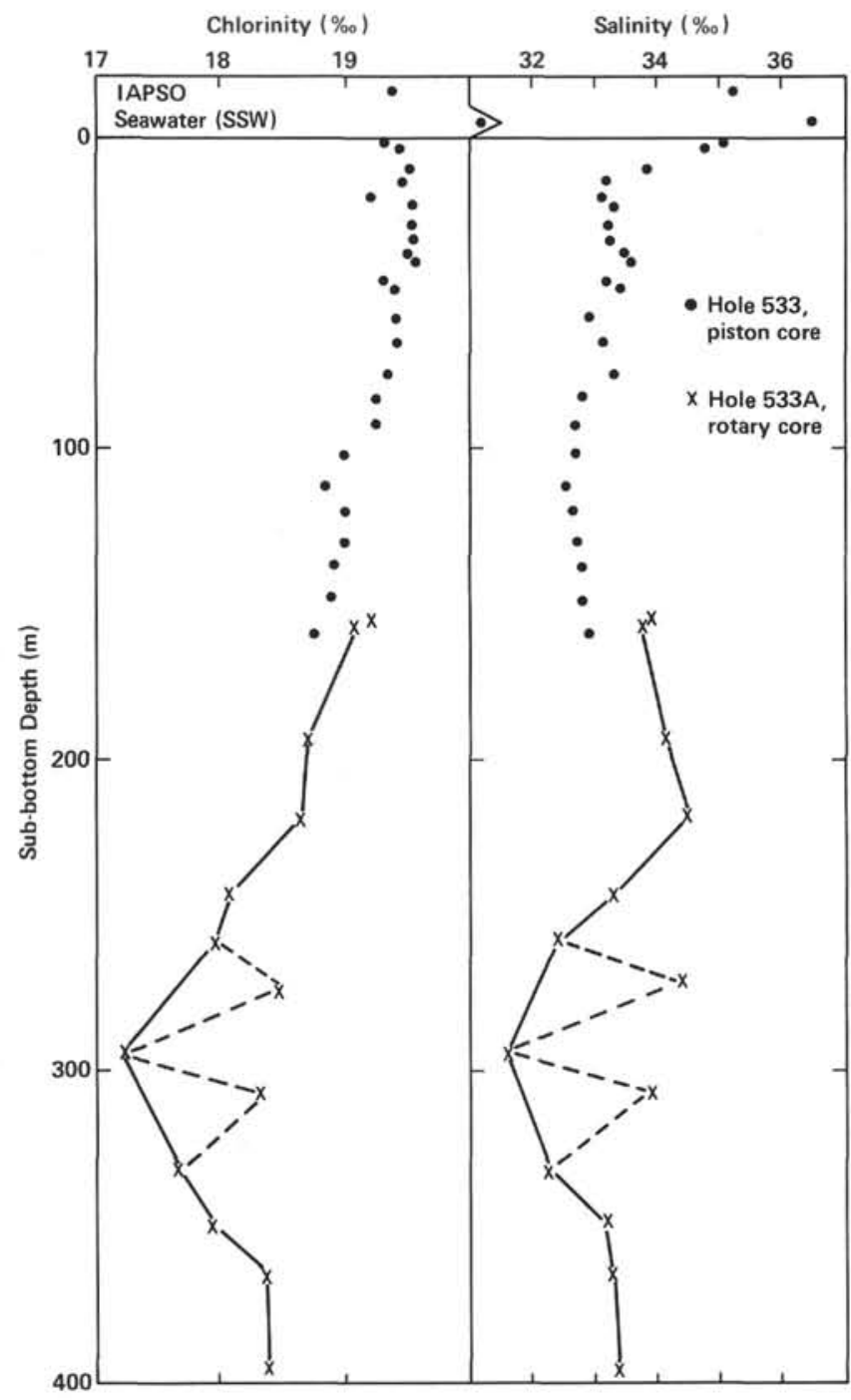

Figure 34 . Chlorinity $(\% \circ)$ and salinity $(\%)$ versus sediment depth at Site 533.

gion at $294 \mathrm{~m}$. Contamination by surface seawater does not seem to be a likely explanation for these high points, because calcium and magnesium values do not show a corresponding increase, and alkalinities are higher, not lower, than neighboring values. Chlorinity and salinity decreases of 5 to $10 \%$ are not uncommon for sediments with a high terrigenous contribution (Sayles and Manheim, 1975) and are often explained by infusion of fresh waters from nearby continental aquifers. But this explanation seems unlikely for the sediments at Site 533; no such decreases have been observed more than $500 \mathrm{~km}$ from the coast. An alternate, more plausible explanation is that the crystalline water structure of the gas hydrate is excluding salt that diffuses to adjacent stratigraphic levels. Hesse and Harrison (1980) have proposed this same idea to explain the low chlorinity and salinity values in sediments associated with gas hydrates at Sites 496 and 497, DSDP Leg 67, off western Guatemala. The results at Site 533 suggest that only a portion $(\sim 10 \%)$ of the pore space at $294 \mathrm{~m}$ may be occupied by gas hydrates and even less pore space is occupied by hydrates in sediments above or below this depth.

\section{PHYSICAL PROPERTIES}

The hydraulic piston core hole, 533, recovered nearly undisturbed sediment samples. However, degassing of the cores imparted a friable nature to the core material, making it difficult to measure undisturbed physical properties. Hole 533A, drilled with a special bit that cut cores slightly smaller than the inside diameter of the core liner, obtained much more disturbed samples. For example, the shear strength in Hole 533 was $1900 \mathrm{~g} / \mathrm{cm}^{2}$ at $166 \mathrm{~m}$, whereas in Hole 533A it dropped to $600 \mathrm{~g} / \mathrm{cm}^{2}$ at $192 \mathrm{~m}$. Below $320 \mathrm{~m}$ in Hole 533A, drilling discs (Kidd, 1978 ) began to form. The formation of the discs indicates that the sediments had reached a stage of induration in which they are relatively undisturbed by the drilling process. As a result, the quality of the physical properties measurements should improve. Physical property data are summarized in Tables 7 and 8 and Figure 35.

\section{Sound Velocity}

Compressional sound velocities were determined only in the upper $20 \mathrm{~m}$ of Hole 533. Gas from $20 \mathrm{~m}$ to total depth attenuated sound transmission and prevented additional measurements except in limestone nodules.

\section{Vane Shear}

Vane shear strength increased regularly down Hole 533 to $150 \mathrm{~m}\left(60-1300 \mathrm{~g} / \mathrm{cm}^{2}\right)$ and jumped to $1700 \mathrm{~g} /$ $\mathrm{cm}^{2}$ at $150 \mathrm{~m}$. The gradient increased sharply to the bottom of the hole (Fig. 35). Lower shear-strength values in Hole 533A are attributed to drilling disturbance. At depths greater than $320 \mathrm{~m}$ where drilling discs formed, the samples fractured.

\section{Wet-Bulk Density}

Wet-bulk density values, corrected to a grain density of $2.7 \mathrm{~g} / \mathrm{cm}^{3}$, show a wide variation even in the "undisturbed" Hole 533. These variations, determined with the 2-minute GRAPE method, correlate with the continuous GRAPE measurements. In Hole 533A, where core disturbance is higher, the higher values may better represent the true wet-bulk density.

\section{Conductivity}

Thermal conductivity was measured at 11 depth positions in cores allowed to equilibrate with room temperature; temperature drift over a 5-min. period preceding measurement was recorded. All values were obtained using the needle-probe method on unsplit liners. The cores were then split, and core quality at the location of the conductivity measurement was noted. Several values were excluded because of core disturbance (Table 8).

Utilizing a method from Hyndman et al. (1974), we corrected the conductivity data to in situ values. The in situ values vary between 3.1 and $3.5 \mathrm{mcal} / \mathrm{cm}-{ }^{\circ} \mathrm{C}$-s $(3.2$ \pm 0.1 ) with no systematic change downsection.

No obvious correlation exists between the wet-bulk density data and lithology. Some variations may result 
Table 7. Physical property data, Site 533 .

\begin{tabular}{|c|c|c|c|c|c|c|c|c|}
\hline \multirow[b]{2}{*}{$\begin{array}{l}\text { Sample } \\
\text { (core-section, cm from } \\
\text { top of section) }\end{array}$} & \multirow[b]{2}{*}{$\begin{array}{l}\text { Sub-bottom } \\
\text { depth } \\
\text { (m) }\end{array}$} & \multirow{2}{*}{$\begin{array}{c}\text { Velocity } \\
(\mathrm{km} / \mathrm{s}) \\
\text { parallel } \\
\text { to } \\
\text { bedding }\end{array}$} & $\begin{array}{r}\text { GRAP } \\
\text { bulk d } \\
(\mathrm{g} / \mathrm{c}\end{array}$ & $\begin{array}{l}\text { Wet- } \\
\text { nsity } \\
m^{3} \text { ) }\end{array}$ & & Gravimetri & & \\
\hline & & & $\begin{array}{l}\text { Parallel } \\
\text { to } \\
\text { bedding }\end{array}$ & $\begin{array}{l}\text { Normal } \\
\text { to } \\
\text { bedding }\end{array}$ & $\begin{array}{c}\text { Bulk } \\
\text { density } \\
\left(\mathrm{g} / \mathrm{cm}^{3}\right)\end{array}$ & $\begin{array}{c}\text { Water } \\
\text { content } \\
(\%)\end{array}$ & $\begin{array}{c}\text { Porosity } \\
(\%)\end{array}$ & $\begin{array}{c}\text { Vane shear } \\
\left(\mathrm{g} / \mathrm{cm}^{3}\right)\end{array}$ \\
\hline Hole 533 & & & & & & & & \\
\hline $1-1,100$ & 1.0 & 1450 & & & & & & \\
\hline $1-1,102$ & 1.0 & & 1.48 & & & & & \\
\hline $1-2,56$ & 2.1 & & & & & & & 82 \\
\hline $1-2,71$ & 2.2 & 1460 & & & & & & \\
\hline $1-2,86$ & 2.4 & 1460 & & & & & & \\
\hline $2-2,112$ & 4.6 & & 1.47 & & & & & \\
\hline $2-2,117$ & 4.6 & 1460 & & & & & & 60 \\
\hline $\begin{array}{l}2-2,120 \\
6-1,128\end{array}$ & $\begin{array}{r}4.6 \\
12.7\end{array}$ & & & & & & & 103 \\
\hline $6-1,130$ & 12.7 & 1470 & & & & & & \\
\hline $6-1,131$ & 12.7 & & 1.62 & & & & & \\
\hline $6-3,20$ & 14.6 & & 1.73 & & & & & \\
\hline $6-3,25$ & 14.6 & & & & & & & 137 \\
\hline $6-3,27$ & 14.7 & 1480 & & & & & & \\
\hline $7-2,93$ & 18.3 & & 1.81 & & & & & \\
\hline $7-2,97$ & 18.4 & & & & & & & 160 \\
\hline $7-2,99$ & 18.4 & 1470 & & & & & & \\
\hline $8-2,111$ & 23.0 & & 1.68 & & & & & \\
\hline $13-2,112$ & $\begin{array}{l}46.5 \\
46.5\end{array}$ & & 1.78 & & & & & 365 \\
\hline $\begin{array}{l}13-2,114 \\
14-2,104\end{array}$ & $\begin{array}{l}46.5 \\
49.6\end{array}$ & & & & & & & 369 \\
\hline $16-2,41$ & 57.0 & & 1.82 & & & & & \\
\hline $17-2,56$ & 61.6 & & & & & & & 451 \\
\hline $17-2,82$ & 61.8 & & 1.75 & & & & & \\
\hline $18-3,3$ & 67.0 & & 1.69 & & & & & 451 \\
\hline $18-3,10$ & 67.1 & & & & & & & 451 \\
\hline $19-2,117$ & 71.2 & & 1.69 & & & & & \\
\hline $20-2,98$ & 75.5 & & 1.66 & & & & & 458 \\
\hline $\begin{array}{l}20-2,103 \\
21-2,91\end{array}$ & $\begin{array}{l}75.5 \\
79.9\end{array}$ & & & & & & & 554 \\
\hline $21-2,98$ & 80.0 & & 1.64 & & & & & \\
\hline $23-2,96$ & 84.5 & & & & & & & 623 \\
\hline $24-2,106$ & 93.6 & & & & & & & 785 \\
\hline $24-2,108$ & 93.6 & & 1.64 & & & & & \\
\hline $25-2,125$ & 98.3 & & 1.66 & & & & & \\
\hline $25-2,133$ & 98.3 & & & & & & & 670 \\
\hline $27-3,80$ & 108.3 & & 1.72 & & & & & \\
\hline $27-3,84$ & 108.3 & & & & & & & 820 \\
\hline $28-3,81$ & 112.8 & & & & & & & 658 \\
\hline $28-3,84$ & 112.8 & & 1.80 & & & & & \\
\hline $30-2,65$ & 120.6 & & 1.71 & & & & & \\
\hline $30-2,70$ & 120.7 & & & & & & & 739 \\
\hline $31-2,76$ & 124.8 & & 1.62 & & & & & \\
\hline $31-2,88$ & 124.9 & & & & & & & 1132 \\
\hline $32-1,115$ & 128.2 & & & & & & & 947 \\
\hline $32-2,90$ & 129.4 & & 1.71 & & & & & \\
\hline $33-2,87$ & 133.9 & & & & & & & 1282 \\
\hline $34-1,102$ & 137.0 & & & & & & & 1143 \\
\hline $34-1,104$ & 137.0 & & 1.63 & & & & & \\
\hline $35-2,100$ & 143.0 & & & & & & & 1131 \\
\hline $35-2,102$ & 143.0 & & 1.78 & & & & & \\
\hline $36-1,57$ & 145.6 & & & & & & & 739 \\
\hline $37-2,76$ & 148.8 & & 1.77 & & 1.72 & 33.7 & 57.9 & \\
\hline $37-2,86$ & 148.9 & & & & & & & 1317 \\
\hline $38-2,90$ & 151.9 & & & & & & & 1686 \\
\hline $38-3,71$ & 153.2 & & & & & & & 1987 \\
\hline $38-3,72$ & 153.2 & & & 1.70 & 1.67 & 36.0 & 60.2 & \\
\hline $39-2,34$ & 155.8 & & & & & & & 1652 \\
\hline $39-3,68$ & 157.7 & & & 1.75 & 1.67 & 35.7 & 59.5 & \\
\hline $40-1,113$ & 159.6 & & & & & & & 1756 \\
\hline $41-2,107$ & 165.6 & & & & & & & 1917 \\
\hline Hole $533 \mathrm{~A}$ & & & & & & & & \\
\hline $7-1,16$ & $180.7^{b}$ & 5.00 & & & & & & \\
\hline $8-2,63$ & 192.1 & & & & & & & 635 \\
\hline $8-2,57$ & 192.1 & & 1.64 & & & & & \\
\hline $8-3,99$ & 194.0 & & & & & & & 496 \\
\hline $13-5,124$ & 245.7 & & 1.66 & & & & & \\
\hline $15-2,67$ & 258.7 & & 1.70 & & & & & \\
\hline $16-5,49$ & 272.5 & & 1.66 & & & & & \\
\hline $17-5,110$ & 282.6 & & 1.64 & & & & & \\
\hline $18-5,46$ & 291.5 & & 1.74 & & & & & \\
\hline $19-2,41$ & 296.4 & & 1.69 & & & & & \\
\hline $20-3,58$ & 307.6 & & 1.77 & & & & & \\
\hline $21-4,104$ & 319.0 & & 1.70 & & & & & \\
\hline $22-4,98$ & 328.5 & & 1.63 & & 1.69 & 34.5 & 58.3 & \\
\hline $22-5,77$ & 330.8 & & 1.80 & & & & & \\
\hline $23-4,71$ & 337.7 & & 1.78 & & & & & \\
\hline $24-6,118$ & 350.7 & & 1.75 & & 1.72 & 33.5 & 57.9 & \\
\hline $25-3,23$ & 354.7 & & 1.75 & & & & & \\
\hline $26-3,118$ & 365.2 & & 1.77 & & & & & \\
\hline $27-2,35$ & 372.4 & & 1.72 & & & & & \\
\hline $28-2,57$ & 382.1 & & & $1.85 ?$ & 1.74 & 33.2 & 57.8 & \\
\hline $29.4,145$ & 395.7 & & 1.81 & & & & & \\
\hline
\end{tabular}

Note: blank spaces indicate no measurements were made.

a 2-minute count.

b Limestone concretion. 
Table 8. Thermal conductivity data, Site 533 .

\begin{tabular}{cccl}
\hline $\begin{array}{c}\text { Sample } \\
\text { (core-section, cm from } \\
\text { top of section) }\end{array}$ & $\begin{array}{c}\text { Sub-bottom } \\
\text { depth } \\
(\mathrm{m})\end{array}$ & $\begin{array}{c}\text { Conductivity } \\
\left(\mathrm{m} \mathrm{cal} / \mathrm{cm}-{ }^{\circ} \mathrm{C}-\mathrm{s}\right)\end{array}$ & \multicolumn{1}{c}{ Remarks } \\
\hline Hole 533 & & & \\
& & & \\
$6-3,34$ & 14.7 & 3.25 & Brown mud \\
$32-2,81$ & 129.3 & 3.52 & Gassy mud \\
$32-2,99$ & 129.5 & 4.11 & Gray gassy mud \\
$38-3,46$ & 153.0 & 3.26 & \\
$39-3,115$ & 153.6 & 3.13 & Gray gassy mud \\
Hole 533A & & & \\
& & & \\
$18-5,45$ & 291.4 & 3.19 & \\
$18-5,51$ & 291.5 & 2.62 & Soft, disturbed \\
$18-5,92$ & 291.9 & 3.29 & \\
$26-4,63$ & 366.1 & 3.23 & Soft \\
$26-4,110$ & 366.6 & 3.57 & May be disturbed \\
$26-4,120$ & 366.7 & 3.99 & \\
\hline
\end{tabular}

from changes in composition with depth, because an assumed grain density of $2.7 \mathrm{~g} / \mathrm{cm}^{3}$ was used to calculate densities. However, no major trends are evident in the smear slide data to suggest significant compositional variations. More likely, the variations reflect the degree of mechanical sample disturbance. In Hole 533, this disturbance may also be due to the degassing of the sediments. The vane shear strength data seem to provide a good correlation with the observed stratigraphic break at $150 \mathrm{~m}$. The vane shear strength abruptly increases to $300 \mathrm{~g} / \mathrm{cm}^{2}$ below the unconformity.

\section{DOWNHOLE INSTRUMENTS}

The combination downhole temperature probe and pore water sampler was deployed four times in Hole 533A. All attempts to collect water samples were futile, the result of equipment malfunction. The temperature probe was successful at three depths (Fig. 36). The operation of this device is reviewed in the Explanatory Notes, this volume. A shorted wire to the thermistor frustrated our first attempt to measure in situ temperatures.

The measurement at $155.5 \mathrm{~m}$ obtained a maximum temperature of $10.3^{\circ} \mathrm{C}$ after $30 \mathrm{~min}$. in the bottom. The slope of the warming trend reveals that equilibrium was not quite reached. The seafloor temperature was a minimum at $2.4^{\circ} \mathrm{C}$, which is somewhat lower than the $2.9^{\circ} \mathrm{C}$ expected from physical oceanography data (Tucholke et al., 1977). At $255.8 \mathrm{~m}$ the probe reached $14^{\circ} \mathrm{C}$ after 42 min. in the sediment, very nearly an equilibrium value. Minimum water temperature of $2.4^{\circ} \mathrm{C}$ was again measured as the tool was lowered by the wire line down the pipe. On removal the tool dropped off the go-devil and fell back down the hole. As a result, no equilibrium mudline temperature was obtained. The final temperature measured was $19.0^{\circ} \mathrm{C}$ at $400.0 \mathrm{~m}$. The temperature profile during the $30 \mathrm{~min}$. in the sediment shows a slight cooling trend attributed to dissipation of heat produced by insertion of the probe into the stiff mud. A $2.8^{\circ} \mathrm{C}$ frictional heat spike was observed as the tool was pulled out of the mud. The $19^{\circ} \mathrm{C}$ reading is close to the equilibrium value. The tool again dropped off the go-devil during the recovery process, and no reliable mudline temperature was recorded.

\section{Discussion}

The primary purpose of the temperature measurements was to determine more precisely the pressure-temperature regime at depth and the relationships of these parameters to the high-amplitude reflection thought to represent the base of the gas-hydrate stability field.

In Figure 37, the temperature gradient is extrapolated to depths suggested for the base of hydrates in this area. The shaded area represents uncertainties in the equilibrium values of the temperature measurements at 255.8 and $400.0 \mathrm{~m}$. Assumptions of increasing conductivity with depth and constant heat flow could be used to adjust the predicted temperature gradient. However, these procedures were not followed because of our limited data. Further, such assumptions of constant heat flow and increasing conductivities do not fit the limited data that suggest constant conductivity; and the effect of heat of formation of hydrates is not known.

The predicted temperatures at the base of the hydrate stability field are within the range expected for the reflection to be coincident with the phase boundary. The thermal gradient from 0 to $155.5 \mathrm{~m}$ is $5.1^{\circ} \mathrm{C} / 100 \mathrm{~m}$, from 155.5 to $400 \mathrm{~m}$ it is $3.6^{\circ} \mathrm{C} / 100 \mathrm{~m}$, and the temperature at $600 \mathrm{~m}$ is estimated at $26.2^{\circ} \mathrm{C}$. The high gradient in the near surface might reflect in situ heat production. Pleistocene changes in water-bottom temperature are not a likely cause, because the "anomaly" in the gradient extends only to $<155 \mathrm{~m}$.

\section{SEISMIC STRATIGRAPHY}

\section{Sonobuoy Results}

During the approach survey to Site 533, two sonobuoy wide-angle reflection profiles were made (Fig. 38). Sonobuoy profile 1 was run southeast across the drill site on the profile where the beacon was launched. Therefore, the position of the first buoy and profile is excellently 


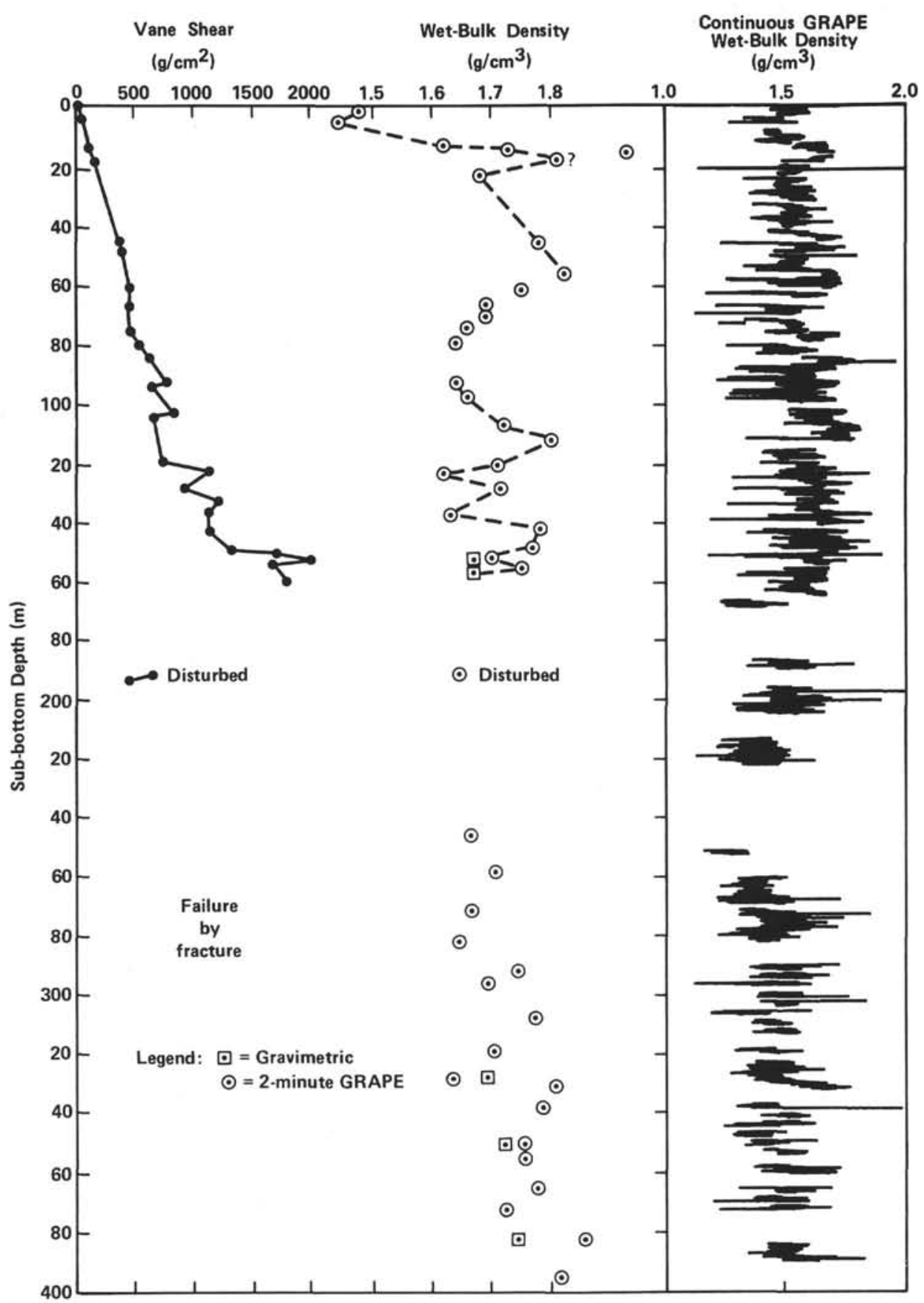

Figure 35. Summary of physical properties, Site 533.

located relative to the drill site. Sonobuoy profile 2 was run perpendicular to the first on a northeasterly course, again with the buoy launched at the beacon for precise geographic location relative to the drill site.

Both sonobuoys were shot on a constant course over a constantly sloping seafloor and sub-bottom structure to eliminate complications in interpretation and calculation. The position of the beginning and end of each sonobuoy profile is indicated on the vertical reflection profiles recorded at the same time (Fig. 38).

The particular buoys used were Ref Tek $73 \mathrm{MHz}$ models $10-\mathrm{L}$ and $20-\mathrm{L}$. Signals were received on a twochannel Select International crystal radio in which the high-frequency water break (direct wave) was separately amplified and mixed with the lower-frequency reflected arrivals. These were passed through a wide-band pass filter and recorded on the EDO 1 recorder.

The direct waves and reflected arrivals were digitized and plotted on $\mathrm{T}^{2}$ versus $\mathrm{X}^{2}$ plots, the $\mathrm{X}$ range being computed from the direct wave traveltime (assuming a horizontal seawater velocity, $\mathrm{V}_{\mathrm{o}}=1.50 \mathrm{~km} / \mathrm{s}$ ). The reflected arrivals for the seafloor, the BSR, Horizon X, and Horizon $\mathrm{A}^{\mathrm{u}} / \beta$ were clearly seen and easily read on both profiles (Fig. 39). Slope corrections were necessary at far ranges; approximately $0.02 \mathrm{~s}$ for Sonobuoy 1 for a seafloor slope of $0.5^{\circ}$, and approximately $0.10 \mathrm{~s}$ for Sonobuoy 2 for a seafloor slope of $2^{\circ}$. The slope corrections were calculated using the equation 


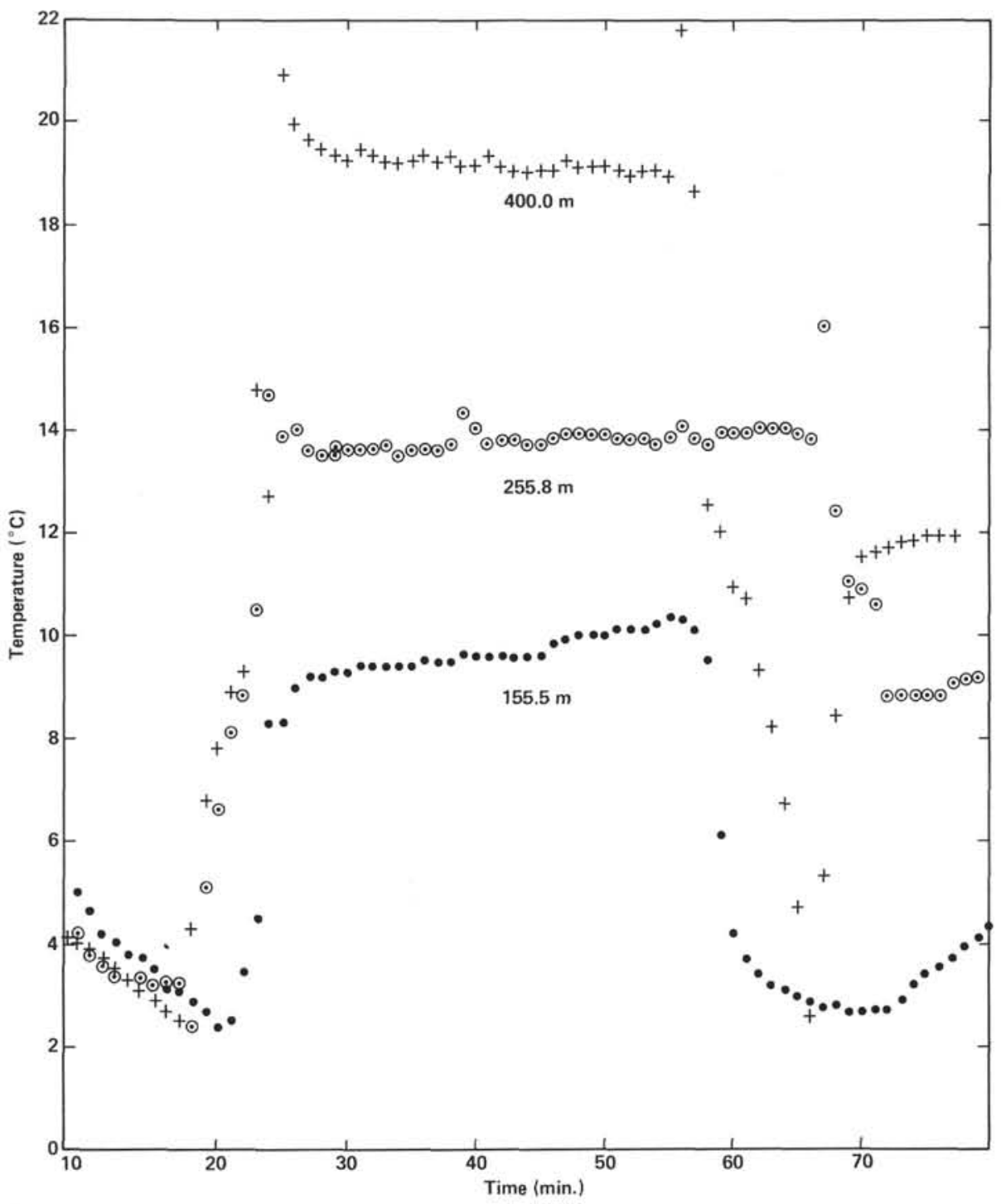

Figure 36. Inhole temperature measurements, Hole 533A.

$$
\mathrm{T}=\frac{2 \mathrm{X} \sin \alpha}{\overline{\mathrm{V}}}
$$

where $\alpha$ is the slope of the reflector.

Unless these slope corrections were applied, significantly lower velocities for the vertical water velocity, $\mathrm{V}_{1}$, were obtained from the $\mathrm{T}^{2}$ versus $\mathrm{X}^{2}$ plots for both sonobuoys (each having been shot downslope). Accordingly, the slope-corrected reflection arrivals were plotted on $\mathrm{T}^{2}$ versus $\mathrm{X}^{2}$ plots for the final calculation of interval velocities. Interval velocities were calculated using the Dix equation:

$$
\mathrm{V}_{n}^{2}=\frac{\overline{\mathrm{V}}_{n}^{2} \mathrm{~T}_{n}-\overline{\mathrm{V}}_{n-1}^{2} \mathrm{~T}_{n-1}}{\mathrm{~T}_{n}-\mathrm{T}_{n-1}}
$$

Velocities calculated by this equation, where the RMS (root mean square) velocities, $\overline{\mathrm{V}}_{n}$, are determined by near-range moveout, are estimated to be accurate to \pm 3 to $5 \%$.
The results of the two sonobuoys are listed in Table 9. Although there is some variation in the velocities between the two sonobuoys, which might be due to the slightly different locations, slopes, and azimuths of the profiles, there is velocity inversion at the BSR indicated on both measurements.

\section{Correlation with Seismic Profiles}

During the approach survey of Site 533, vertical seismic reflection profiles were run using two Bolt air guns, one with 150 -in. ${ }^{3}$ capacity and one with a 40 -in..$^{3}$ capacity with a wave shaper. The resulting Challenger profiles are of high quality and provide reasonably high resolution (Fig. 13). The two prominent reflectors seen on the Challenger profile are the angular unconformity at 0.15 -s sub-bottom depth and the bottom-simulating reflector (BSR) at $0.60 \mathrm{~s}$ (Fig. 40). These are exactly at the same depths as on the projected position for Site 533 on the reference Robert Conrad multichannel profile MC-87 (Fig. 11). Also, on both the Challenger and Conrad profiles the northwesterly sloping reflectors between the un- 


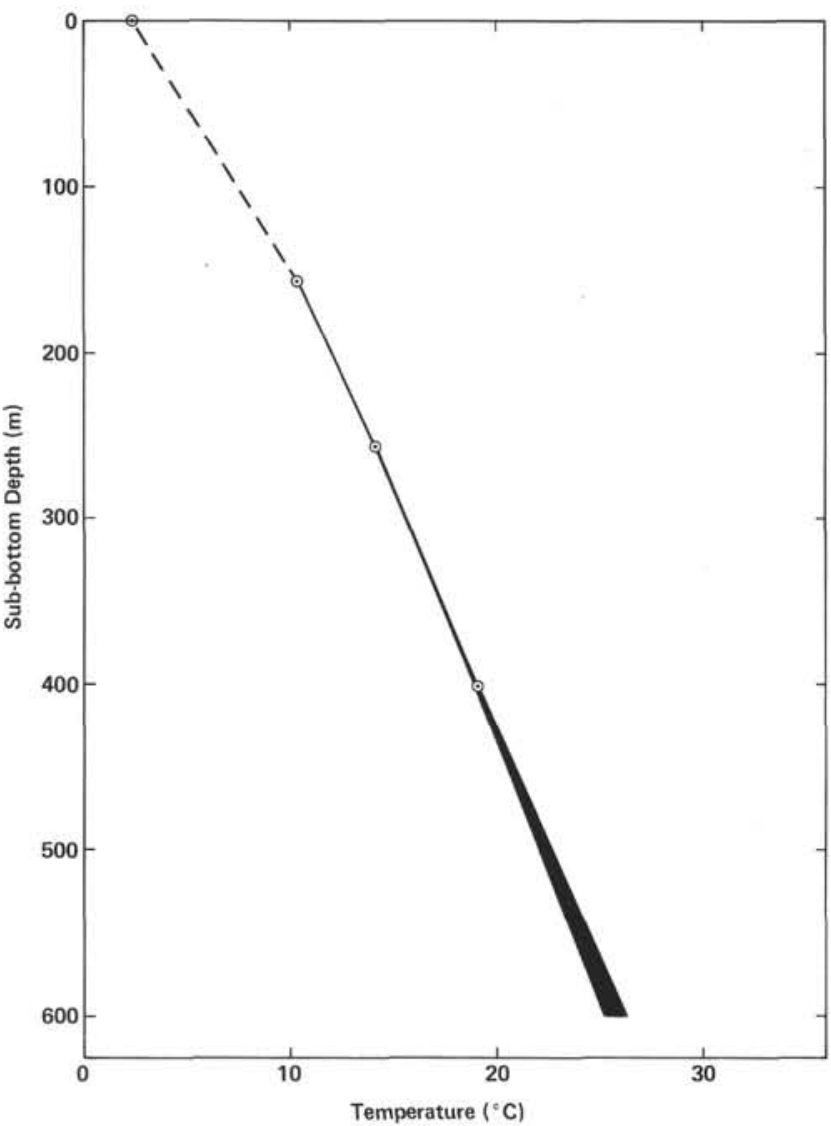

Figure 37. Extrapolated temperature profile at Site 533. (Shaded area of the profile is uncertainty in extrapolation.)

conformity and the BSR are evident, as is the acoustically transparent zone above the BSR.

The angular unconformity on the seismic profiles is correlated with the contact between lower Pleistocene Lithologic Unit 1 and upper Pliocene Unit 2 (Fig. 40). At this hiatus, the physical properties measurements indicate an abrupt increase in shear strength to up to 1900 $\mathrm{g} / \mathrm{cm}^{2}$, which is good verification of this impedance contrast.

Below the unconformity, the northwesterly sloping reflectors are interpreted to be caused by the "concretions" of calcified mudstones and thin layers of gas hydrates encountered in the Pliocene section. The interpretation that the acoustic transparent zones are caused by massive gas hydrates obscuring bedding impedance contrasts was not substantiated at Site 533-where no massive gas hydrates were encountered and few strong bedding contrasts were present (concretions and hydrates parallel to bedding). Possibly the transparency is due to the otherwise homogeneous nature of the Pliocene muds themselves.

Using the correlation of the angular unconformity reflector with the break in lithologies and physical properties, we calculated the velocity in the Pleistocene sediments as approximately $2.0 \mathrm{~km} / \mathrm{s}$. This calculation agrees fairly well with the velocities determined by the two sonobuoys for the interval above the BSR.

\section{Discussion of Seismic Velocities}

Both the vertical reflection profile correlations and the sonobuoy measurements determine velocities that are considered unusually high for normally compacted marine sediments of such a young age (Bryan, 1974; Stoll, 1974; Ewing and Hollister, 1972). Also, the velocity inversion measured at the BSR is unusual for normally compacted marine sediments. These high velocities above the BSR were interpreted to be caused by the gas hydrates in the pore spaces of the sediments; the lower velocities below the BSR were interpreted as the return of the pore fluids to their nonhydrated state or even as the accumulation of free gas in the bubble phase (Bryan, 1974; Dillon et al., 1980; Paull and Dillon, 1979).

The drilling at Site 533 does not directly support this hypothesis, even though it has not excluded the possibility completely. For one thing, no massive gas hydrates were recovered in the drilled interval-only one case of a few thin beds scattered throughout one core was documented. So the hypothesis now must be modified to state that only a portion of the sediments above the BSR are hydrated. The question must be answered whether this portion of hydrated sediments is enough to increase the average velocity in the interval to agree with the observations of velocities of about $2.0 \mathrm{~km} / \mathrm{s}$.

Using the time-average equation for the average velocity, $\overline{\mathrm{V}}$, through a hydrated/nonhydrated sediment stack,

$$
\bar{V}=\frac{V_{H} V_{N H}}{V_{H}+\left(V_{N H}-V_{H}\right) H}
$$

where $\mathrm{V}_{\mathrm{H}}$ is the velocity in hydrated sediments, $\mathrm{V}_{\mathrm{NH}}$ is the velocity in nonhydrated sediments, and $\mathrm{H}$ is the percentage of section in thin hydrate layers, it is possible to calculate the average velocity. Stoll (1974) reports that $\mathrm{V}_{\mathrm{H}}$ can be as high as 2.7 to $3.6 \mathrm{~km} / \mathrm{s}$, whereas normal nonhydrated sediment velocities, $\mathrm{V}_{\mathrm{NH}}$, are taken to be $1.8 \mathrm{~km} / \mathrm{s}$. Using these values in equation (3), it appears that as much as 20 to $30 \%$ of the section must be hydrated to produce an average velocity of $2.0 \mathrm{~km} / \mathrm{s}$. It was not apparent from drilling at Site 533 that 20 to $30 \%$ of the sediments were gas hydrates, unless the hydrates were confined to such thin layers that decomposed so rapidly they were not visible in the opened cores. The PCB experiments might not detect small amounts of hydrates whose degassing volume would merge with the normal expanding gases of the nonhydrated section. Just what the resolution capability of the PCB experiments is has yet to be determined.

Perhaps the percentage of hydrated section that yields the observed higher $2.0 \mathrm{~km} / \mathrm{s}$ velocities is even smaller than 20 to $30 \%$. Very little is known about the mechanics of hydrates in controlling physical properties such as velocity. To quote from Stoll (1974):

Relatively small amounts of crystalline hydrate adhering to the sediment particles at their contact points or faces may increase the stiffness of the 


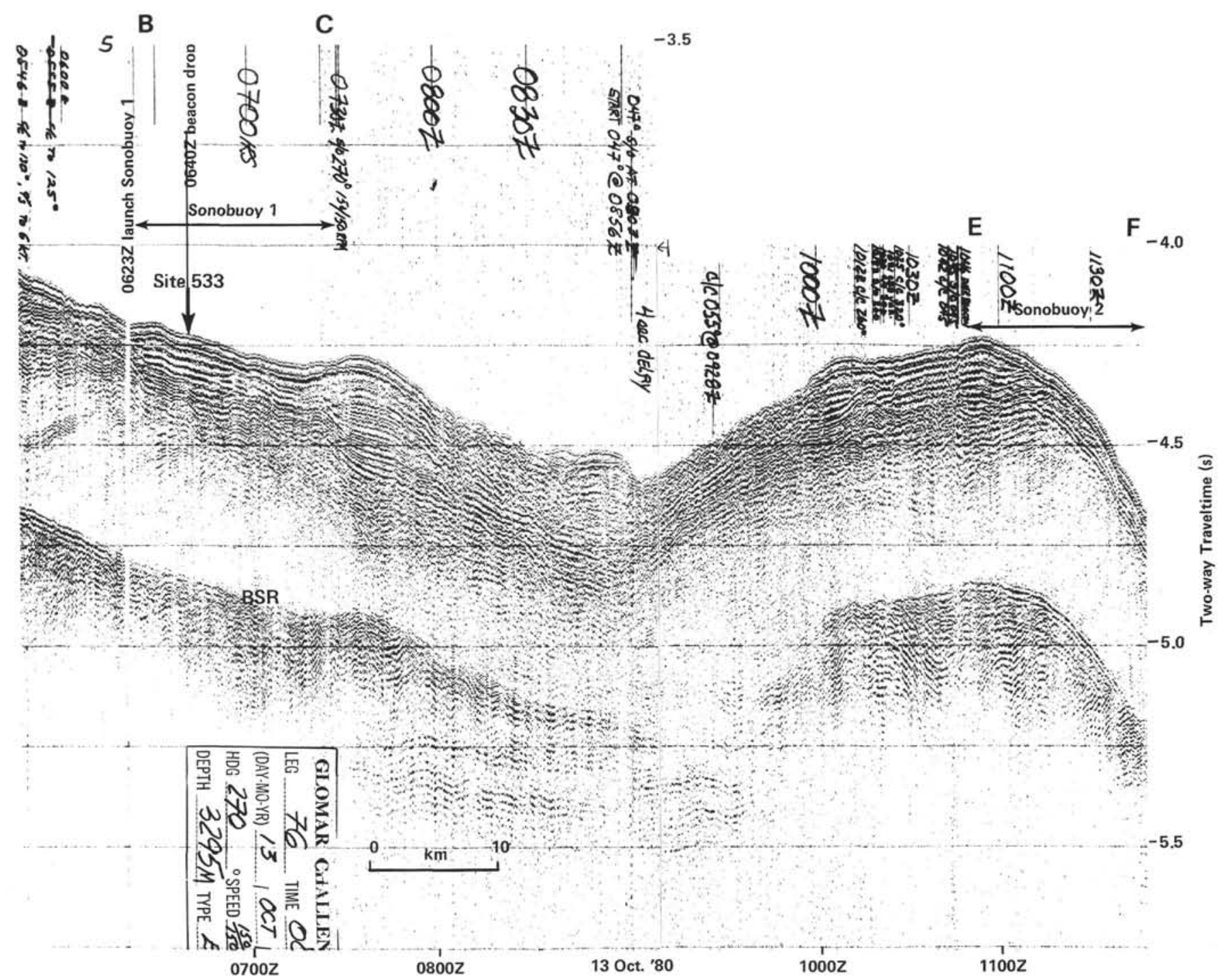

Figure 38. Air-gun single-channel seismic reflection profile made by Glomar Challenger en route to Site 533. (Locations of sonobuoys are also shown.)

sediment skeleton in much the same manner as cementation or lithification. This could produce marked changes in wave velocity...even though the quantity of gas is well below the amount required to combine with all the available water in the interstices of the sediment.

Given this possibility, perhaps there is enough hydrate present at Site 533 to explain the velocity measurements.

\section{SUMMARY AND CONCLUSIONS}

Continuous coring to a depth of $400 \mathrm{~m}$ at Site 533 accomplished all of the objectives save the logging of the hole, which was prevented by failure of the bit release. Drilling into and proving the presence of gas-hydrated sediments on the Blake Outer Ridge was a key achievement. This accomplishment is especially satisfying in that the site is so well documented as to acoustic properties and seismic stratigraphy, lithology and ages of the sediments, and also the temperature regime. For the first time, a quantitative geochemical experiment on gas hydrates was conducted that benefitted greatly from the detailed geological and geophysical record now available.

\section{Lithology and Age}

Two well-identified lithologic units are found in Site 533 (Fig. 41). The oldest one is Unit 2, consisting of middle to upper Pliocene, dark greenish gray, calcareous clay and mud that shows a general lack of bedding structure and a high mid-Pliocene sedimentation rate of $21 \mathrm{~cm} / 10^{3} \mathrm{yr}$., decreasing to $8 \mathrm{~cm} / 10^{3} \mathrm{yr}$. in the late Pliocene. The presence of "fissile" structure in Unit 2 suggests a criterion for identification of contourites in finegrained muds. A very low sedimentation rate of 1 $\mathrm{cm} / 10^{3} \mathrm{yr}$. during the latest Pliocene to earliest Pleistocene indicates sediment by-passing or erosion, which would agree with the seismic interpretation of a hiatus between Units 1 and 2 (Figs. 41 and 42). This hiatus dates back to 2.0 to $1.8 \mathrm{Ma}$ and may be related to the rapid escalation of northern hemisphere glaciation in 

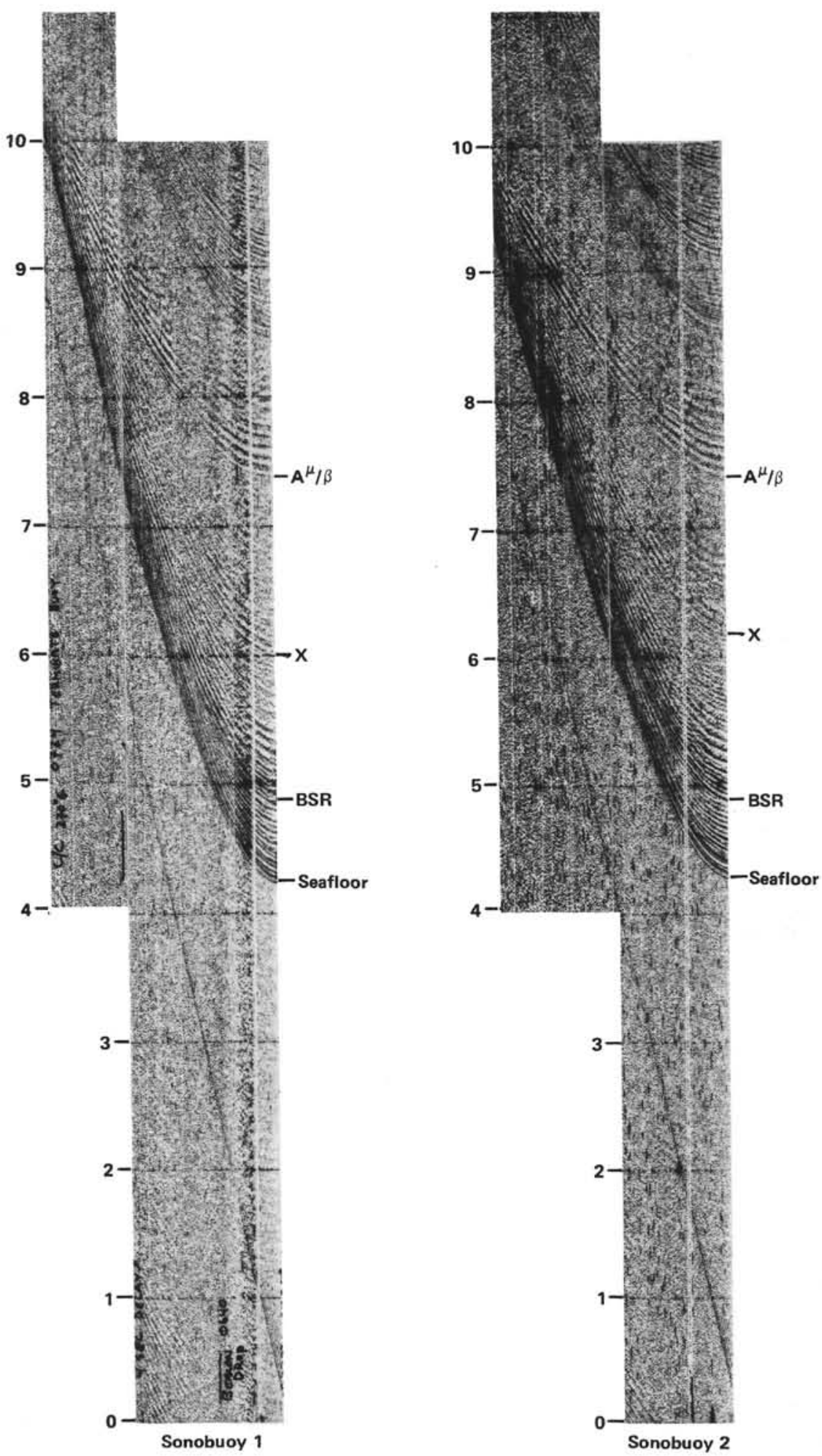

Figure 39. Original sonobuoy profiles shot at Site 533.

the middle Pliocene (around 3.5 Ma), which enhanced deep circulation and deep basin erosion.

Unit 1 is a light gray green- and rose-colored, nannofossil-rich clay and mud deposited in the Pleistocene through the Holocene by contour-following currents at relatively high sedimentation rates of $7 \mathrm{~cm} / 1000 \mathrm{yr}$.
This unit shows striking variations in microfossil assemblages, in calcium carbonate content, and in color that are associated with the climate variations during the Pleistocene. Unexpectedly low levels of reworked nannofossils point to predominantly Quaternary sources of the clastics, such as are found along the continental 
Table 9. Results of Sonobuoys 1 and 2, Site 533.

\begin{tabular}{|c|c|c|c|c|c|c|}
\hline \multirow[b]{2}{*}{ Interval } & \multicolumn{2}{|c|}{ Sonobuoy 1} & \multicolumn{2}{|c|}{ Sonobuoy 2} & \multicolumn{2}{|c|}{ Average of two } \\
\hline & $\mathrm{T}_{n}(\mathrm{~s})$ & $\mathrm{v}_{n}(\mathrm{~km} / \mathrm{s})$ & $\mathrm{T}_{n}(\mathrm{~s})$ & $\mathrm{V}_{n}(\mathrm{~km} / \mathrm{s})$ & $\mathrm{T}_{n}(\mathrm{~s})$ & $\mathrm{V}_{n}(\mathrm{~km} / \mathrm{s})$ \\
\hline BSR & 4.22 & 2. & 9 & 2.10 & 4.2 & 2.28 \\
\hline BSR to $\mathrm{X}$ & $4.85-6.01$ & 2.22 & $4.89-6.19$ & 1.41 & $4.87-6.10$ & 1.81 \\
\hline $\mathrm{X}$ to $\mathrm{A}^{\mathrm{u} / \beta}$ & $6.01-7.41$ & 4.40 & $6.19-7.42$ & 2.83 & $6.10-7.42$ & 3.61 \\
\hline
\end{tabular}

slopes northward. The continuously cored and geographically oriented record makes Site 533 ideal for detailed investigations of the Quaternary deep ocean.

It has been suggested that the Blake Outer Ridge was formed by sediment transported by geostrophic contour currents (Heezen et al., 1966; Ballard, 1966; Ewing et al., 1966; Markl et al., 1970; Lancelot et al., 1972; Ewing and Hollister, 1972; and Hollister et al., 1972a). Although there is substantive evidence for this conclusion in the research just cited as well other work (e.g., Amos et al., 1971), the lack of obvious current-derived structures in the visual observations of cores at Site 533 on the Ridge led to significant shipboard discussion concern- ing the depositional processes that produced those sediments, as well as the implications of the genetic term "contourite."

A contourite, as defined in the literature (Heezen and Hollister, 1964; Heezen et al., 1966; Hollister and Heezen, 1972; and Bouma and Hollister, 1973), is a deposit of redistributed sediment, transported by relatively slowmoving ( $<50 \mathrm{~cm} / \mathrm{s})$, contour-following bottom currents. In the case of the continental margin of the United States, the Western Boundary Under Current (WBUC), a geostrophic thermal-haline density current formed in the Arctic Ocean, is considered the transport medium for contourites on the continental rise (Heezen et al., 1966; Bryan, 1970; Amos et al., 1971; and Hollister and Heezen, 1972). Sediments thought to have been deposited as contourites are defined in the literature as having sharp upper and lower bedding contacts and as being thinly bedded, well-sorted, graded, heavy-mineral placered, and well-laminated (see Table 10). This definition, however, is based on observations of a few particular deep-sea sediment cores retrieved from areas close to

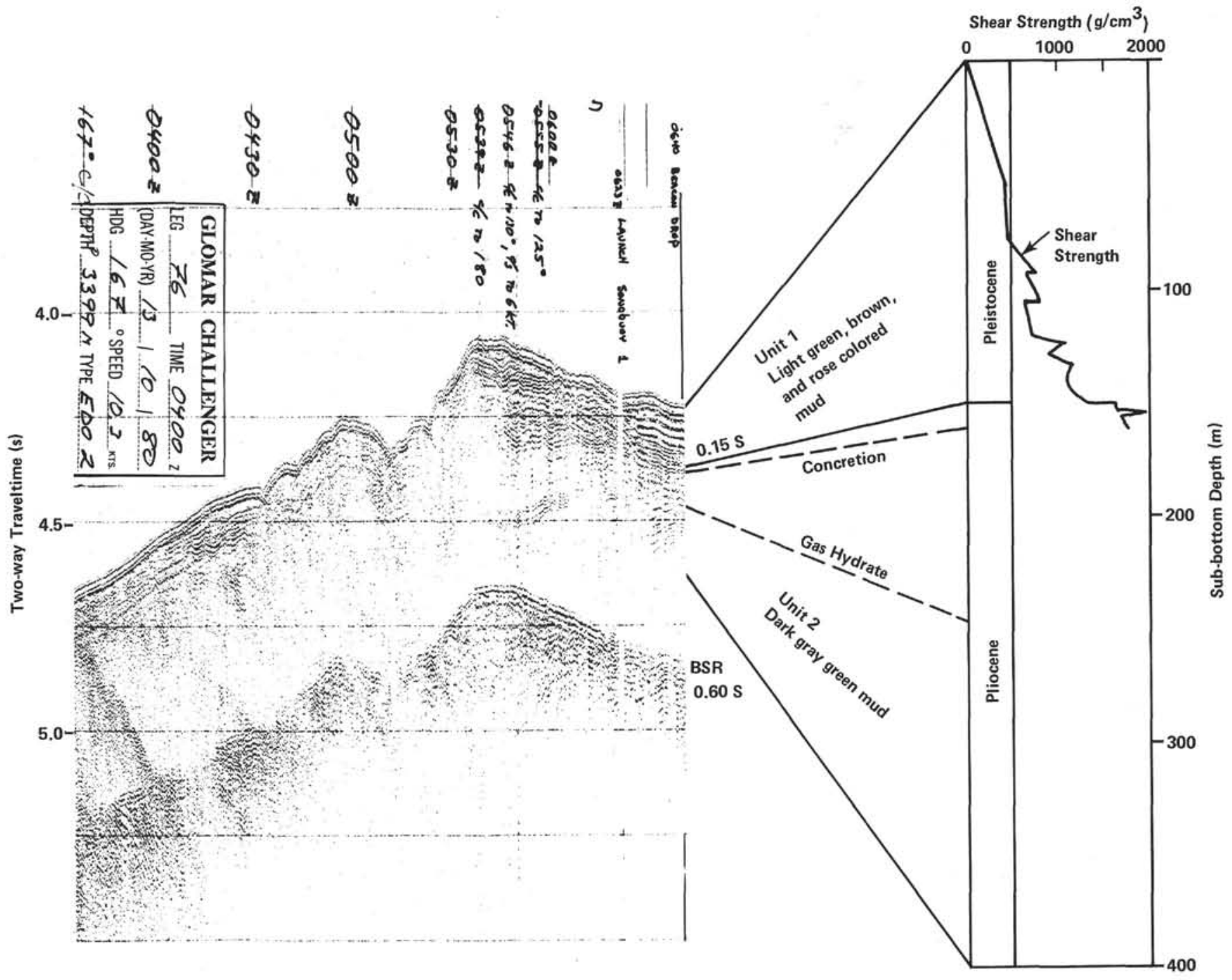

Figure 40. Correlation of the seismic reflection profile at Site 533 with lithologic units and physical properties. 


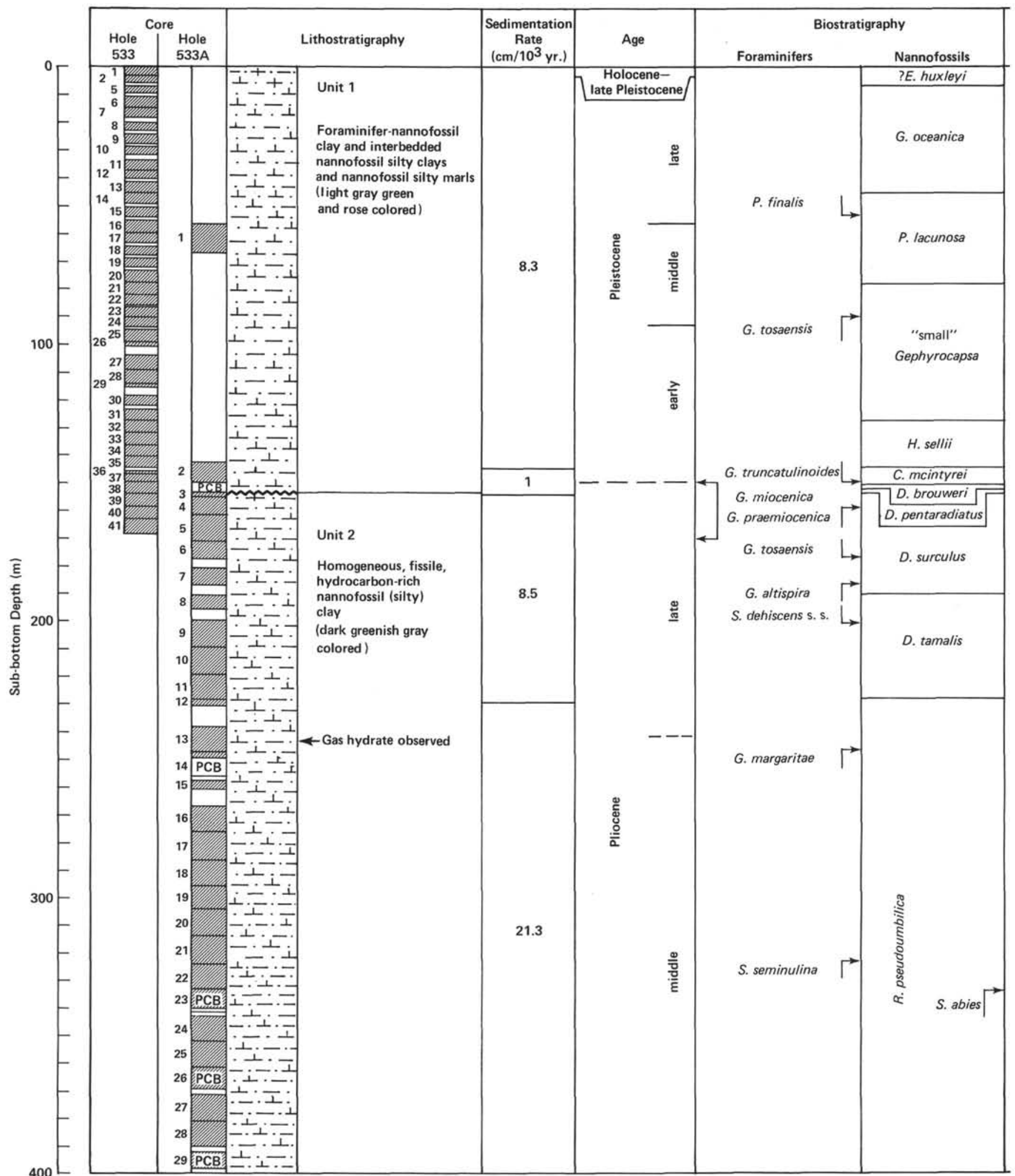

Figure 41. Stratigraphic summary of Site 533. ( $\Gamma=$ FAD [first appearance datum]; $L=$ LAD [last appearance datum].)

turbidity current sources where there was abundant, fine sand and silt available (e.g., Hollister and Heezen, 1972). Although it has been suggested that much finegrained material may be transported by contour currents several thousand kilometers from the source (Hee- zen et al., 1966), there does not appear to be evidence showing "classic contourites" far downstream from sources of coarse grain material, such as at Site 533.

Visual observations in the cores of Site 533 show several stratigraphic levels where the sediment may have 


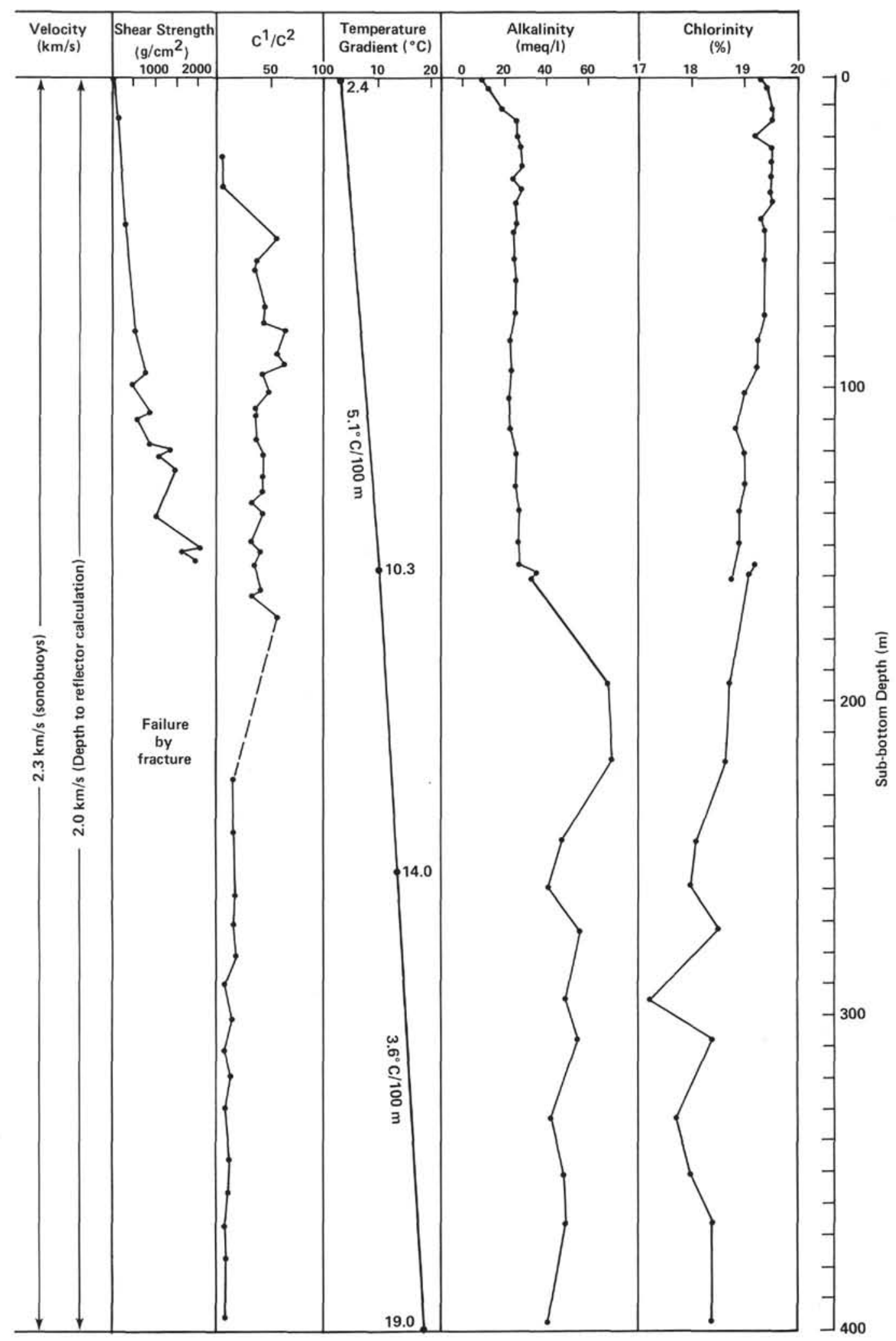

Figure 41. (Continued).

been deposited as contourites (e.g., Samples 533-16-2, $33-34 \mathrm{~cm}$ and $533-16-3,14-15 \mathrm{~cm}, 72-73 \mathrm{~cm}, 97-98 \mathrm{~cm}$, and $99-100 \mathrm{~cm}$ ). At these depths there are layers of very fine silt with no visible structures. These thin beds, however, do not appear to be the rule but rather the exception at Site 533, whereas contourites are supposed to be "ubiquitously laminated."

This observation is contrasted with that of "fissile" structures in the Pliocene sediments recovered at Site 533 (Unit 2). The very nature of these structures may 


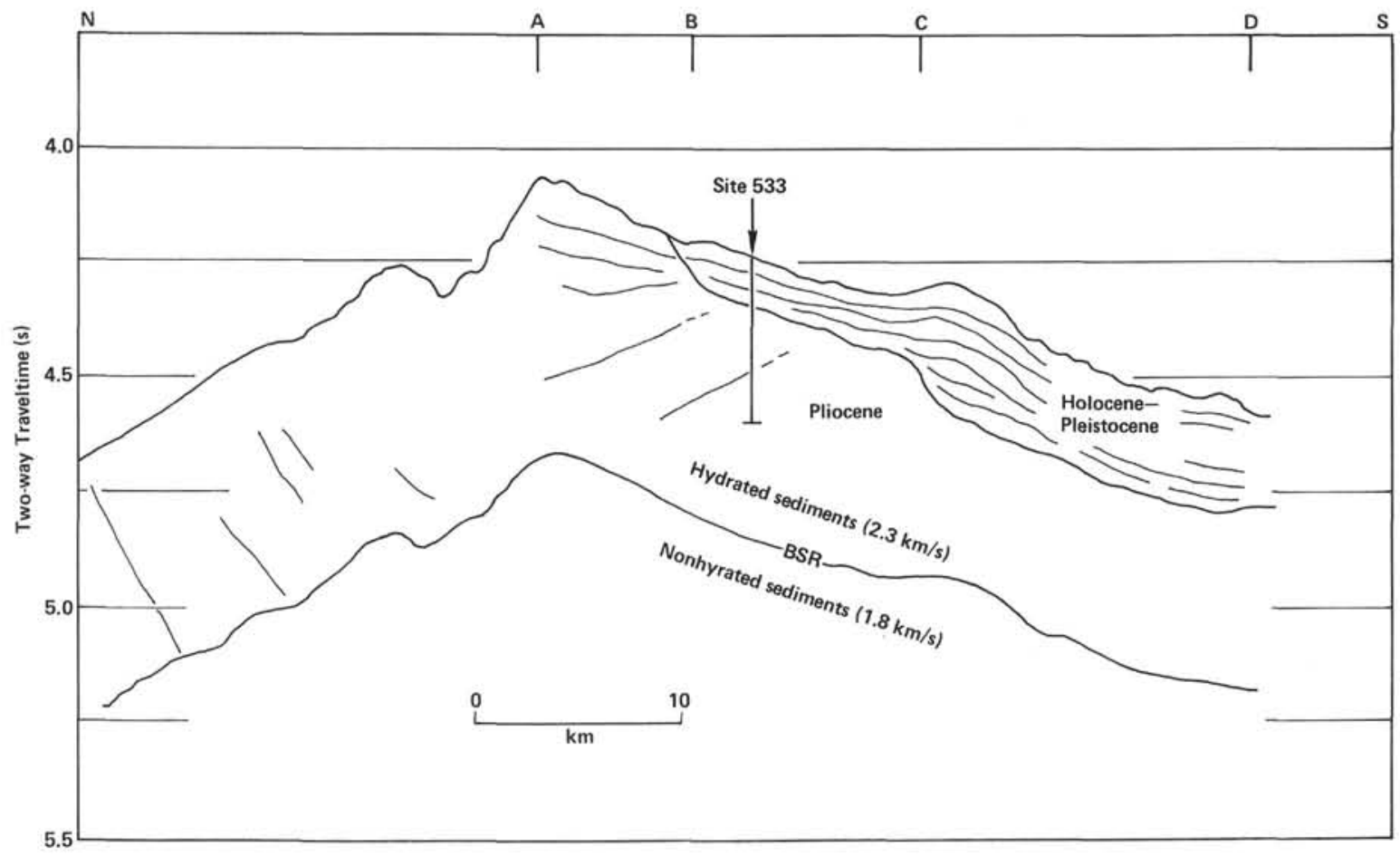

Figure 42. Interpreted seismic reflection profile at Site 533. (Location points A-D are shown in Fig. 12.)

Table 10. Principal characteristics of turbidite and contourite sand or silt (from Bouma and Hollister, 1973).

\begin{tabular}{|c|c|c|c|c|}
\hline & & Turbidite & Contourite & Conclusions \\
\hline \multicolumn{2}{|c|}{ Size sorting } & $\begin{array}{l}\text { Moderate to poorly sorted } \\
\quad(<1.50)\end{array}$ & Well to very well sorted $(<0.75)$ & Contourite is better sorted. \\
\hline \multicolumn{2}{|c|}{ Bed Thickness } & Usually $10-100 \mathrm{~cm}$ & Usually $<5 \mathrm{~cm}$ & $\begin{array}{l}\text { Contourite has thinner } \\
\text { bedding. }\end{array}$ \\
\hline \multirow{2}{*}{ 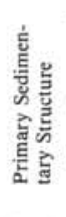 } & Grading & $\begin{array}{l}\text { Normal grading ubiquitous, } \\
\text { bottom contacts sharp, } \\
\text { upper contacts poorly } \\
\text { defined }\end{array}$ & $\begin{array}{l}\text { Normal and reverse grading, bot- } \\
\text { tom and top contacts sharp }\end{array}$ & $\begin{array}{l}\text { Contourite tends to be less } \\
\text { regularly graded and up- } \\
\text { per contacts are sharp. }\end{array}$ \\
\hline & $\begin{array}{l}\text { Cross } \\
\quad \text { Laminations } \\
\text { Horizontal } \\
\text { Laminations }\end{array}$ & $\begin{array}{l}\text { Common, accentuated by } \\
\text { concentrations of lutite } \\
\text { Common in upper portion } \\
\text { only, accentuated by } \\
\text { concentration of lutite }\end{array}$ & $\begin{array}{l}\text { Common, accentuated by concen- } \\
\text { trations of heavy minerals } \\
\text { Common throughout, accentuated } \\
\text { by concentrations of heavy } \\
\text { minerals or foraminifera shells }\end{array}$ & $\begin{array}{l}\text { Contourite contrasts sharp- } \\
\text { ly with turbidite in that } \\
\text { heavy mineral placers } \\
\text { are in the form of small- } \\
\text { scale stratification. }\end{array}$ \\
\hline \multicolumn{2}{|c|}{ Massive Bedding } & $\begin{array}{l}\text { Common, particularly in } \\
\text { lower portion }\end{array}$ & Absent & $\begin{array}{l}\text { Contourite is ubiquitously } \\
\text { laminated }\end{array}$ \\
\hline \multirow{4}{*}{ 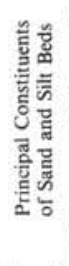 } & Grain Fabric & $\begin{array}{l}\text { Little or no preferred grain } \\
\text { orientation in massive } \\
\text { graded portions }\end{array}$ & $\begin{array}{l}\text { Preferred grain orientation paral- } \\
\text { lel to the bedding plane is } \\
\text { ubiquitous throughout bed }\end{array}$ & $\begin{array}{l}\text { Contourite has better grain } \\
\text { orientation. }\end{array}$ \\
\hline & $\begin{array}{l}\text { Matrix } \\
(<2 \mu \mathrm{m})\end{array}$ & $10-20 \%$ & $0-5 \%$ & Contourite has less matrix. \\
\hline & Microfossils & $\begin{array}{l}\text { Common and well pre- } \\
\text { served, sorted by size } \\
\text { throughout bed }\end{array}$ & $\begin{array}{l}\text { Rare and usually worn or broken, } \\
\text { often size-sorted in placers }\end{array}$ & $\begin{array}{l}\text { Contourite shows more evi- } \\
\text { dence of reworking. }\end{array}$ \\
\hline & $\begin{array}{l}\text { Plant and } \\
\text { Skeletal } \\
\text { Remains }\end{array}$ & $\begin{array}{l}\text { Common and well pre- } \\
\text { served, sorted by size } \\
\text { throughout bed }\end{array}$ & Rare and usually worn or broken & $\begin{array}{l}\text { Contourite shows more evi- } \\
\text { dence of reworking. }\end{array}$ \\
\hline \multicolumn{2}{|c|}{ Classification } & $\begin{array}{l}\text { Graywacke and sub- } \\
\text { graywacke }\end{array}$ & $\begin{array}{l}\text { Subgraywacke, arkose, and } \\
\text { orthoquartzite }\end{array}$ & $\begin{array}{c}\text { Contourite is more } \\
\text { "mature." }\end{array}$ \\
\hline
\end{tabular}

suggest layered sedimentation of clays by moderate velocity currents $(5-10 \mathrm{~cm} / \mathrm{s})$. The transport of large floculates of clays (as large as $100 \mu \mathrm{m}$ in diameter) has been suggested by Flood (1978) and by Kolla et al. (1980) to explain the mechanics of migrating sediment waves present in the Blake Basin and the Mozambique Basin, respectively. The visual observations will need to be followed by microscopic investigations of these structures to determine (1) the presence of preferential primary layering, and (2) the existence of large clay floculates.
In the area of the Blake Outer Ridge and Site 533, studies of the nepheloid layer (Ewing and Thorndike, 1965; Biscaye and Eittreim, 1974 and 1977) strongly indicate that suspension of fine particulates is the mechanism of transport for large volumes of redistributed sediment. Undoubtedly, the dropping of clay- and silt-size particles from the nepheloid layer will produce a sediment deposit like that recovered at Site 533. These sediments were deposited from contour-following currents and are therefore "contourites." But because they are 
from suspensates, these "mud" contourites exhibit none of the structures of bottom-traction deposits, as do those sediments originally defined as "contourites."

The shipboard observations at Site 533 imply that new criteria must be developed for the classification of fine-grained (mud) contourites. These criteria may require the application of other than visual observations, such as x-radiography, clay mineralogy, and detailed size analyses of the silt- and clay-size fractions to establish sorting characteristics. At the least, the "ubiquitously laminated" criterion (Table 10) must be discarded.

\section{Acoustic Properties and Seismic Stratigraphy}

Well-positioned sonobuoy measurements made by Glomar Challenger at Site 533 yielded compressionalwave velocities of approximately $2.3 \mathrm{~km} / \mathrm{s}$ above the bottom-simulating reflector. These relatively high velocities contrast with the more normal sediment velocities, approximately $1.8 \mathrm{~km} / \mathrm{s}$, measured for the interval below the BSR (Fig. 42). Such occurrences of velocity inversions at the BSR have been observed elsewhere on the Blake Outer Ridge, and it is thought to be a real situation over most of the area. The higher velocities above the BSR can be attributed to the presence of thin layers of gas hydrates interlayered with normal sediments. The spatial distribution and actual thickness of the gas-hydrate beds are still enigmatic, as is the actual amount of gas-hydrate layers needed to cause these higher seismic velocities.

The seismic stratigraphy at Site 533 is well documented by the Challenger profile (Figs. 13 and 42) and the reference Conrad multichannel Profile MC-87. The Pleistocene through Holocene sequence is a well stratified unit that onlaps an angular unconformity at the site. Bedding structures in the Pleistocene-Holocene sequences are typical of the mud-wave structures that occupy much of the Blake Outer Ridge. Evidence such as downlap and sigmoidal geometries in the mud-wave bedding structures suggest migration and prograding buildup. Several hypotheses on this mud-wave accretion have been put forward, and it is uncertain whether the sediment waves move as dunes or antidunal forms. Nevertheless, some kind of buildup and migration is documented.

The northwesterly sloping Pliocene reflectors at Site 533 that are terminated by the angular unconformity are correlated with calcitic concretions and gas-hydrate layers. There is every reason to believe that these diagenetic occurrences are parallel to primary bedding planes. Drilling at Sites 102, 103, and 104 proved that biostratigraphic datums, also parallel to bedding planes, passed through the BSR in an angular manner and were also truncated at the seafloor at those sites. By analogy, the same interpretations of the seismic stratigraphy are made for Site 533 (Fig. 42).

\section{Temperature}

Temperatures are well documented at Site 533 by three well equilibrated measurements at different depths (Fig. 41). These measurements reveal temperatures as high as $19^{\circ} \mathrm{C}$ at a 400 -m depth and near-linear temperature gradients of $3.6^{\circ} \mathrm{C} / 100 \mathrm{~m}$ near the bottom of the hole. A slightly higher gradient of $5.1^{\circ} \mathrm{C} / 100 \mathrm{~m}$ at the upper part of the hole has several possible explanations, but nothing to deny the validity of the measurements.

Extrapolation of these temperature measurements to the depth of the BSR, at approximately $600 \mathrm{~m}$, indicates that temperatures of $\pm 27^{\circ} \mathrm{C}$ constitute a range in which methane gas hydrate would decompose (Fig. 8). The temperature measurements agree with the interpretation that the BSR is a phase-change boundary between gashydrated sediments and normal sediments.

The BSR closely mimics the present seafloor in the vicinity of Site 533 (see Fig. 42 profile). But the drilling at Site 533 now indicates that this seafloor has been built up several hundred meters since the Pleistocene by contourite deposits. The unconformity at Site 533 that the Pleistocene sediments onlap is the old seafloor. Therefore, the BSR should have followed the position of the unconformity over this part of the seismic profile until only about $1 \mathrm{Ma}$. That the BSR so closely resembles the seafloor suggests that the BSR is an active chemical phase-change boundary, which quickly responds to changes in pressure and temperature to occupy a new position with time.

\section{Geochemical Measurements}

Geochemical analyses at Site 533 show that the hemipelagic sediments in this region of the Blake Outer Ridge contain high concentrations of methane below a sub-bottom depth of about $50 \mathrm{~m}$. These analyses confirm the previous observations made on Leg 11, where the presence of gaseous sediments was noted on the Blake Outer Ridge.

Accompanying the methane at Site 533 are small but significant concentrations of higher molecular-weight hydrocarbon gases that tend to increase in abundance with depth. The methane/ethane ratios that average 35,000 in the top $200 \mathrm{~m}$ of sediment suggest that the gases are the result of biogenic processes. Preliminary measurements of the carbon isotopic composition of the methane support a biological origin for this gas. Below $200 \mathrm{~m}$ to the bottom of the hole at $400 \mathrm{~m}$ the methane/ ethane ratios decrease to about 4000 , indicating the effects of early thermal diagenesis.

At $\sim 240 \mathrm{~m}$ conclusive evidence was obtained for the presence of gas hydrate. Pressure and volume measurements of 20:1 volumetric expansion (gas volume: part fluid volume) along with visual observation of frothy sediment and chemical analyses of evolved gases all indicate that gas hydrate was sampled. The molecular distribution of hydrocarbon gases from the decomposed gas hydrate showed the preferential fractionation resulting from the hydrate cage structure that excludes the hydrocarbon $n$-butane and larger hydrocarbons.

Pressures obtained during sequential venting of the pressure core barrel followed a saw-tooth pattern that also indicated that gas hydrates are present at this site. Analyses of the composition of evolved gases showed a constant methane/ethane ratio and an increase in abun- 
dance of propane and higher molecular-weight hydrocarbons during the duration of the pressure-release experiments from this tool.

Finally, chlorinity and salinity of pore waters at this site decrease with depth. This depletion can be explained by the exclusion of salt from gas-hydrate structures and diffusion of salt to adjacent stratigraphic levels. If this mechanism is operative, only a small yet undetermined portion of the pore space is occupied by gas hydrates at this site.

\section{REFERENCES}

Amos, A. F., Gordon, A. L., and Schneider, E. D., 1971. Water masses and circulation patterns in the region of the Blake-Bahama Outer Ridge. Deep-Sea Res., 18:145.

Ballard, J. A., 1966. Structure of the lower continental rise hills of the western North Atlantic. Geophysics, 31:506.

Bé, A. W. H., Damuth, J. E., Lott, L., and Free, R., 1976. Late Quaternary climatic record in western equatorial Atlantic sediment. In Cline, R. M., and Hays, J. D. (Eds.), Investigation of Late Quaternary Paleoceanography and Paleoclimatology. Geol. Soc. Am. Mem., 145:165-200.

Benson, W. E., Sheridan, R. E., and Shipboard Scientific Party, 1978. Site 388: lower continental rise hills. In Benson, W. E., Sheridan, R. E., et al., Init. Repts. DSDP, 44: Washington (U.S. Govt. Printing Office), 23-67.

Berggren, W. A., Van Couvering, J. A., 1974. The Late Neogene; biostratigraphy, geochronology and paleoclimatology of the last 15 million years in marine and continental sequences. Palaeogeogr., Palaeoclimatol., Palaeoecol., 16(1/2):1-216.

Bernard, B. B., Brooks, J. M., and Sackett, W. L., 1978. Light hydrocarbons in recent Texas continental shelf and slope sediments. $J$. Geophys. Res., 87:4053-4061.

Biscaye, P. E., and Eittreim, S. L., 1977. Suspended particulate loads and transports in nepheloid layers of the abyssal Atlantic Ocean. Mar. Geol., 23:155-172.

1974. Variations in benthic boundary layer phenomena; nepheloid layers in the North American Basin. In Gibbs, R. (Ed.), Suspended Solids in Water: New York (Plenum), pp. 227-260.

Bouma, A. H., and Hollister, C. D., 1973. Deep ocean basin sedimentation. In Middleton, G. V., and Bouma, A. H. (Eds.), Turbidites and Deep-Water Sedimentation. SEPM Short Course, pp. 79-118.

Bryan, G. M., 1970. Hydrodynamic model of the Blake Outer Ridge. J. Geophys. Res., 75(24):4530.

1974. In situ Indications of gas hydrate. In Kaplan, I. R., (Ed.), Nature of Gases in Marine Sediments: New York (Plenum Press), pp. 299-308.

Claypool, G. E., 1976. Manual in Pollution Prevention and Safety. JOIDES Journal, 4(1):C7a.

Claypool, G. E., Presley, B. J., and Kaplan, I. R., 1973. Gas analysis in sediment samples from Legs $10,11,13,14,15,18$, and 19. In Creager, J. S., Scholl, D. W., et al., Init. Repts. DSDP, 19: Washington (U.S. Govt. Printing Office), 879-884.

Dillon, W. P., Grow, J. A., and Paull, C. K., 1980. Unconventional gas hydrate seals may trap gas off Southeast U.S. Oil \& Gas J., Jan. 7, 124-130.

Ewing, J., Ewing, M., and Leyden, R., 1966. Seismic profiler survey of the Blake Plateau. Bull. Am. Assoc. Pet. Geol., 50(9):1948.

Ewing, J. I., and Hollister, C. D., 1972. Regional aspects of deep sea drilling in the western North Atlantic. In Hollister, C. D., Ewing, J. I., et al., Init. Repts. DSDP, 11: Washington (U.S. Govt. Printing Office), 951-973.

Ewing, M., and Thorndike, E. M., 1965. Suspended matter in deep ocean water. Science, 147(3663):1291.

Flood, R. D., 1978. Studies of deep sea sedimentary microtopography in the North Atlantic Ocean [Ph.d. dissert.]. Massachusetts Institute of Technology and Woods Hole Oceanographic Institution, Woods Hole, Mass.

Galimov, E. M., Chinyonov, V. A., and Ivanov, Ye. N., 1980. Isotopic composition of methane carbon and the relative content of the gaseous hydrocarbons in the deposits of the Moroccan Basin of the
Atlantic Ocean (DSDP Sites 415 and 416). In Lancelot, Y., Winterer, E. L., et al., Init. Repts. DSDP, 50: Washington (U.S. Govt. Printing Office), 615-622.

Gartner, S., (1977). Calcareous nannofossil biostratigraphy and revised zonation of the Pleistocene. Mar. Micropaleontol., 2:1-25.

Hand, J. H., Katz, D. L., and Verma, V. K., 1974. Review of gas hydrates with implication for ocean sediments. In Kaplan, I. R. (Ed)., Natural Gases in Marine Sediments: New York (Plenum), pp. 179-194.

Heezen, B. C., and Hollister, C. D., 1964. Deep-sea current evidence from abyssal sediments. Mar. Geol., 1:141.

Heezen, B. C., Hollister, C. D., and Ruddiman, W. F., 1966. Shaping of the continental rise by deep geostrophic contour currents. Science, 152(3721):502.

Hersey, J. B., Bunce, E. T., Wyrick, R. F., and Dietz, F. T., 1959. Geophysical investigation of the continental margin between Cape Henry, Virginia and Jacksonville, Florida. Bull. Geol. Soc. Am., 70:437-466.

Hesse, R., and Harrison, W. E., 1980. Abnormally low pore-water salinities in deep marine sections of the continental margins related to gas-hydrate (clathrate) occurrence. Geol. Soc. Am. Abstracts with Programs, 12:446. (Abstract)

Hollister, C. D., Ewing, J. I., and Shipboard Scientific Party, 1972a. Sites 102, 103, 104: Blake-Bahama Outer Ridge (Northern End). In Hollister, C. D., Ewing, J. I., et al., Init. Repts. DSDP, 11: Washington (U.S. Govt. Printing Office), 135-218.

Hollister, C. D., Ewing, J. I., et al., 1972b. Init. Repts. DSDP, 11: Washington (U.S. Govt. Printing Office).

Hollister, C. D., and Heezen, B. C., 1972. Geologic effects of ocean bottom currents: western North Atlantic. In Gordon, A. L. (Ed.), Studies in Physical Oceanography (Vol. 2): New York (Gordon and Breach), 37-66.

Hunt, J. M., 1979. Petroleum Geochemistry and Geology: San Francisco (Freeman).

Hyndman, R. D., Erickson, A. J., and Von Herzen, R. P., 1974. Geothermal measurements on DSDP Leg 26. In Davies, T., Luyendyk, B. P., et al., Init. Repts. DSDP, Washington (U.S. Govt. Printing Office), 451-464.

Katz, D. L., Cornell, D., Kobayashi, R., Poettmann, F. H., and Vary, J. A., 1959. Handbook of Natural Gas Engineering: New York (McGraw-Hill).

Kidd, R. B., 1978. Core-discing and other effects in DSDP Leg 42A Mediterranean sediment cores. In Hsu, K., Montadert, L., et al., Init. Repts. DSDP, 42, Pt. 1: Washington (U.S. Govt. Printing Office), 1143-1149.

Kolla, V., Eittreim, S., Sullivan, L., Kostecki, J., Burckle, L. H., 1980. Current-controlled, abyssal microtopography and sedimentation in Mozambique Basin, southwest Indian Ocean. Mar. Geol., 34:171-206.

Kostecki, J. A., 1976. Paleoclimatology and paleoceanography of the North Atlantic during the past 125,000 years: the interaction between the Subpolar Water Mass and the Gulf Stream during the past glacial epoch (Wisconsin) [M.A. thesis]. Queens College, C.U.N.Y., New York.

Kvenvolden, K. A., and McMenamin, M. A., 1980. Hydrates of natural gas: a review of their geologic occurrence. Geol. Surv. Circ., 825:11.

Kvenvolden, K. A., and Redden, G. D., 1980. Hydrocarbon gas in sediment from the shelf, slope and basin of the Bering Sea. Geochim. Cosmochim. Acta, 44:1145-1150.

Lancelot, Y., and Ewing, J. I., 1972. Correlation of natural gas zonation and carbonate diagenesis in Tertiary sediments from the Northwest Atlantic. In Hollister, C. D., Ewing, J. I., et al., Init. Repts. DSDP, 11: Washington, (U.S. Govt. Printing Office), 791-799.

Lancelot, Y., Hathaway, J. C., and Hollister, C. D., 1972. Lithology of sediments from the western North Atlantic, Leg 11, Deep Sea Drilling Project. In Hollister, C. D., Ewing, J. I., et al., Init. Repts. DSDP, 11: Washington (U.S. Govt. Printing Office), 901-950.

Larson, V. F., Robson, V. B., and Foss, G. N., 1980. Deep ocean coring-récent operational experiences of the Deep Sea Drilling Project. Proc. 55th Ann. Fall Tech. Conf. Soc. Pet. Engr. AIME, pp. 2-6. 
McIver, R. D., 1974. Hydrocarbon gas (methane) in canned Deep Sea Drilling Project core samples. In Kaplan, I. R. (Ed.), Natural Gases in Marine Sediments: New York (Plenum), pp. 63-69.

Markl, R. G., Bryan, G. M., and Ewing, J. I., 1970. Structure of the Blake-Bahama Outer Ridge. J. Geophys. Res., 75:4539-4555.

Mitchum, R. M., Jr., Vail, P. R., and Sangree, J. B., 1977. Seismic stratigraphy and global changes of sea level. Part 6: Stratigraphic interpretation of seismic reflection patterns, in depositional sequences. In Payton, C. E. (Ed.), Seismic Stratigraphy-Applications to Hydrocarbon Exploration. Am. Assoc. Pet. Geol. Mem., 26:117-134.

Paull, C. K., and Dillon, W. P., 1981. The appearance and distribution of the gas hydrate reflection in the Blake Ridge Region offshore southeastern United States. U.S. Geol. Surv. Misc. Field Studies Map.

Sayles, F. L., and Manheim, F. T., 1975. Interstitial solutions and diagenesis in deeply buried marine sediments: results from the Deep Sea Drilling Project. Geochim. Cosmochim. Acta, 43:103-127.

Sayles, F. L., Manheim, F. T., and Waterman, L. S., 1972. Interstitial water studies on small core samples, Leg 11. In Hollister, C. D., Ewing, J. I., et al., Init. Repts. DSDP, 11: Washington (U.S. Govt. Printing Office), 997-1008.

Scientific Party, Leg 66, 1979. Middle America Trench. Geotimes, 24(9):20-22.

Scientific Party, Leg 68, 1979. The Caribbean connection. Geotimes, 24(12):18-19.

Sheridan, R. E., Golovchenko, X., and Ewing, J. I., 1974. Late Miocene turbidite horizon in the Blake-Bahama Basin. Am. Assoc. Pet. Geol. Bull., 58:1797-1805.
Shipley, T. H., Buffler, R. T., and Watkins, J. S., 1978. Seismic stratigraphy and geologic history of Blake Plateau and adjacent western North Atlantic continental margin. Am. Assoc. Pet. Geol. Bull., 62:792-812.

Shipley, T. H., Houston, M. H., Buffler, R. T., Shaub, F. J., McMillen, K. J., Ladd, J. W., and Worzel, J. L., 1979. Seismic evidence for widespread possible gas hydrate horizons on continental slopes and rises. Am. Assoc. Pet. Geol. Bull., 63:2204-2213.

Stainforth, R. M., Lamb, J. L., Luterbacher, H., Beard, J. H., and Jeffords, R. M., 1975. Cenozoic planktonic foraminiferal zonation and characteristics of index forms. Univ. Kans. Paleontol. Contrib., 62:1-162 and Appendix.

Stoll, R. D., 1974. Effects of gas hydrates in sediments. In Kaplan, I. R. (Ed.), Nature of Gases in Marine Sediments: New York (Plenum Press), pp. 235-248.

Tucholke, B. E., Bryan, G. M., and Ewing, J. I., 1977. Gas hydrate horizons detected in seismic profiles data from the western North Atlantic. Am. Assoc. Pet. Geol. Bull., 61:698-707.

Uchupi, E., 1968. Atlantic continental shelf and slope of the United States-physiography. U.S. Geol. Surv. Prof. Pap. 529-C.

Whelan, J. K., and Sato, S., 1980. C $1-C_{5}$ hydrocarbons from core gas pockets, Deep Sea Drilling Project Legs 56 and 57, Japan Trench Transect. In Scientific Party, Init. Repts. DSDP, 56, 57, Pt. 2: Washington (U.S. Govt. Printing Office), 1335-1347.

Date of Initial Receipt: March 30, 1982 


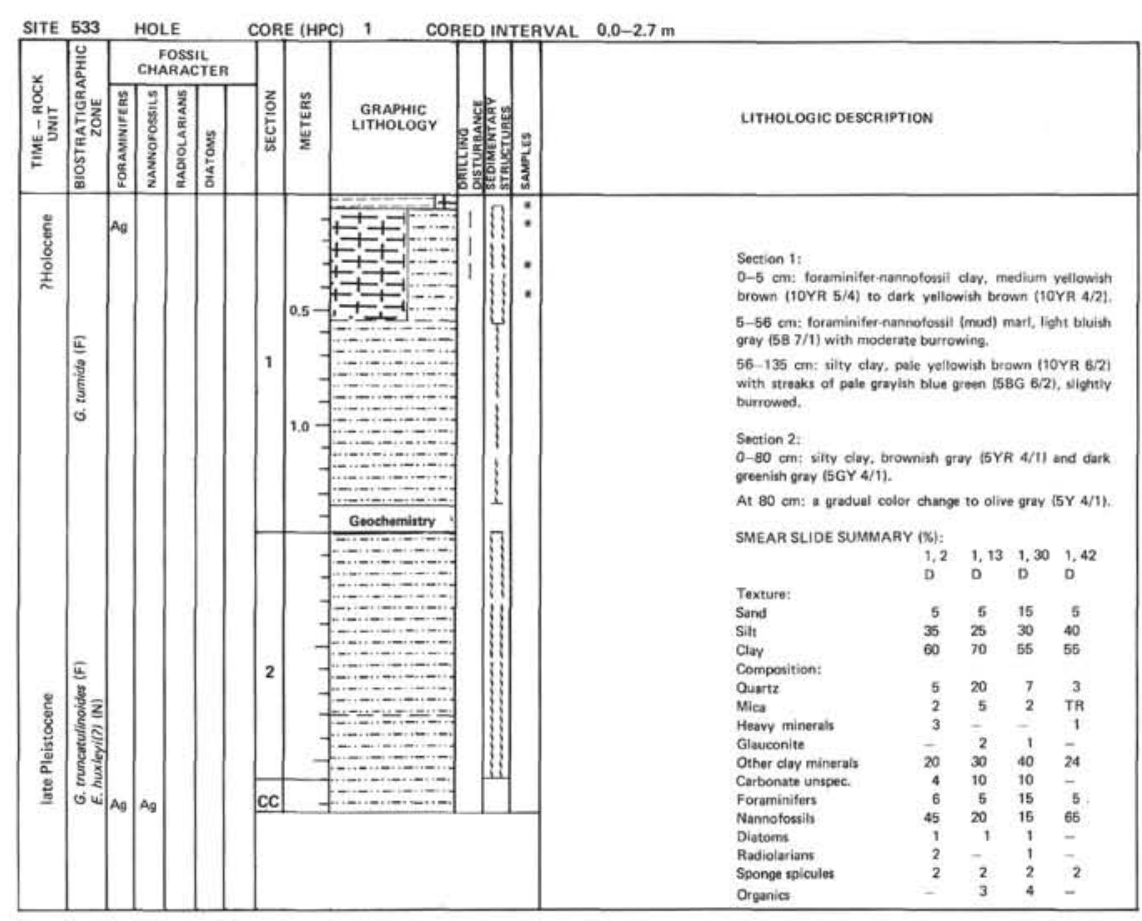

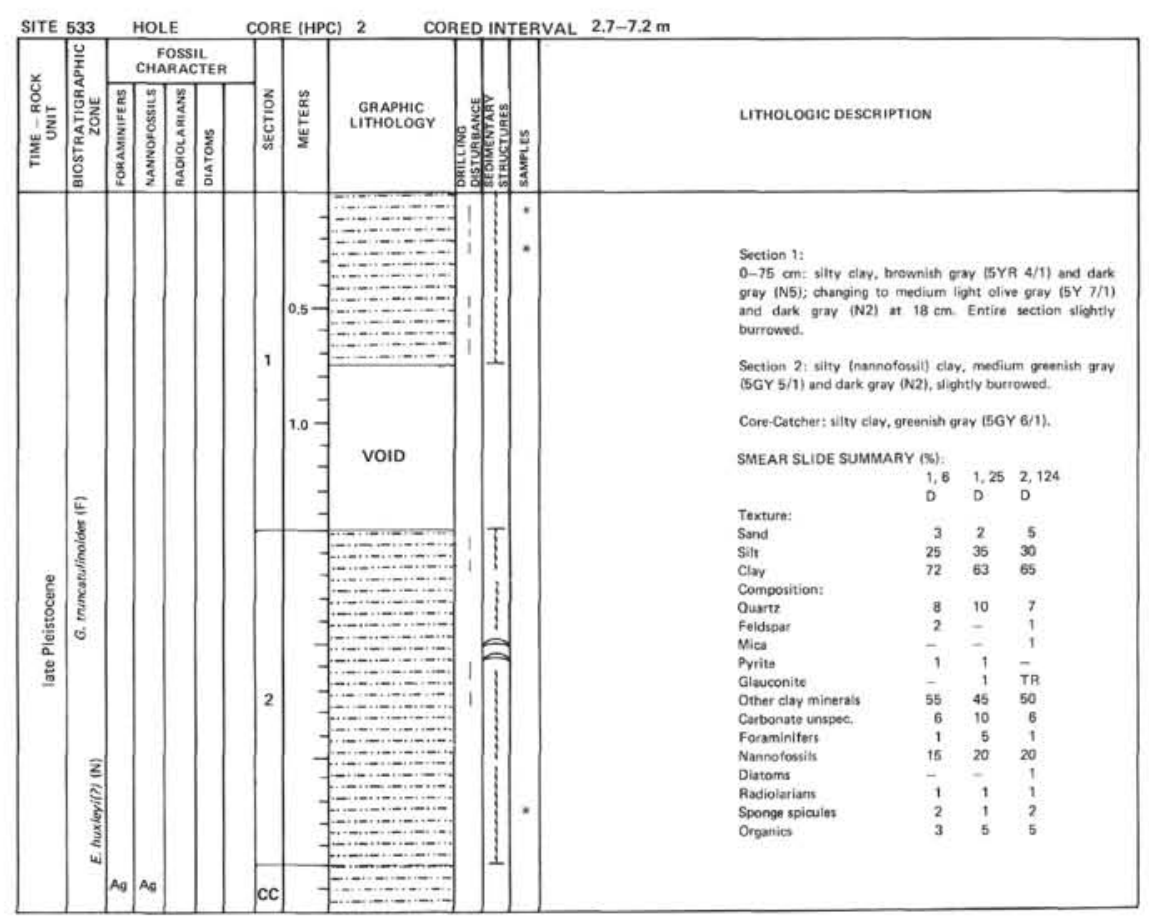

Information on core description sheets, for ALL sites, represents field notes taken aboard ship under time pressure. Some of this information has been refined in accord with postcruise findings, but production schedules prohibit definitive correlation of these sheets with subsequent findings. Thus the reader should be alerted to the occasional ambiguity or discrepancy. 

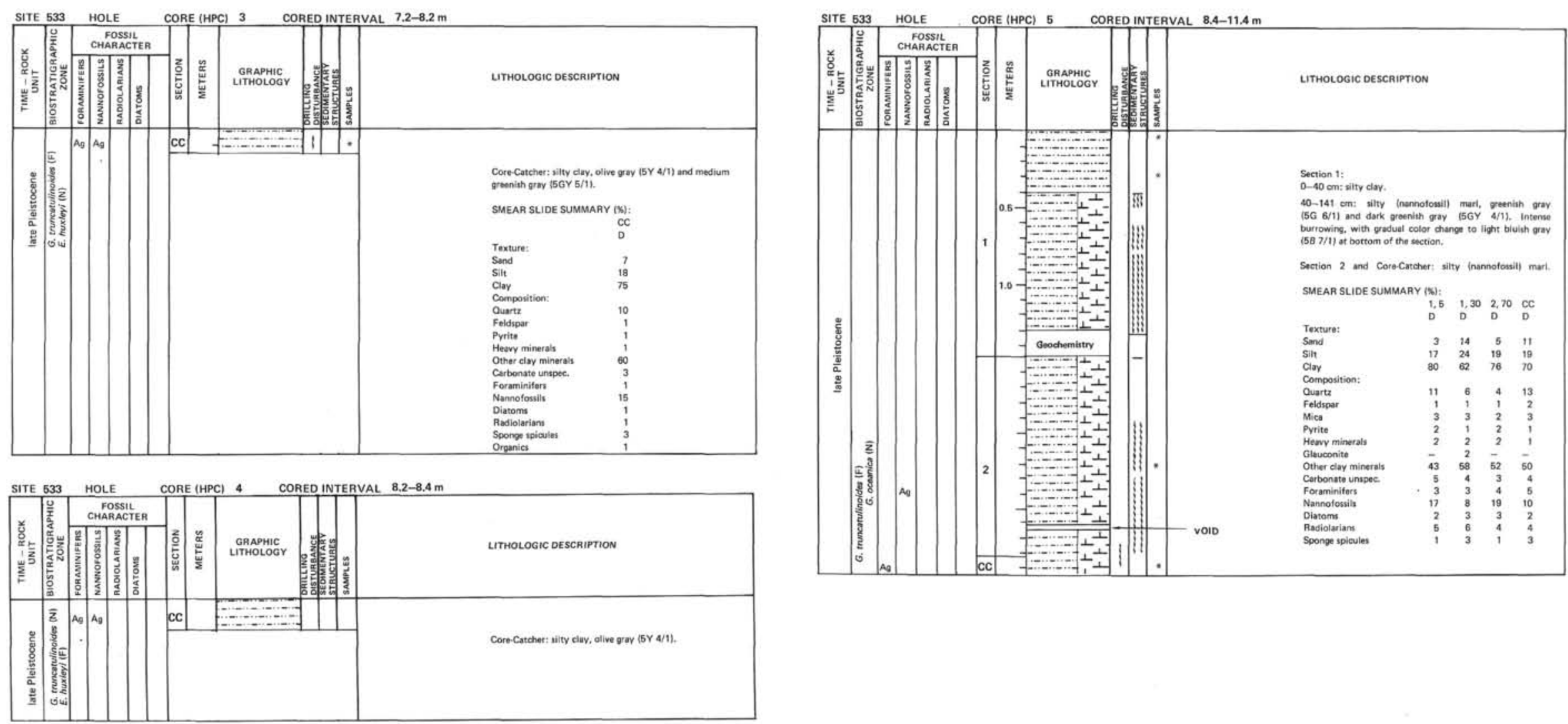


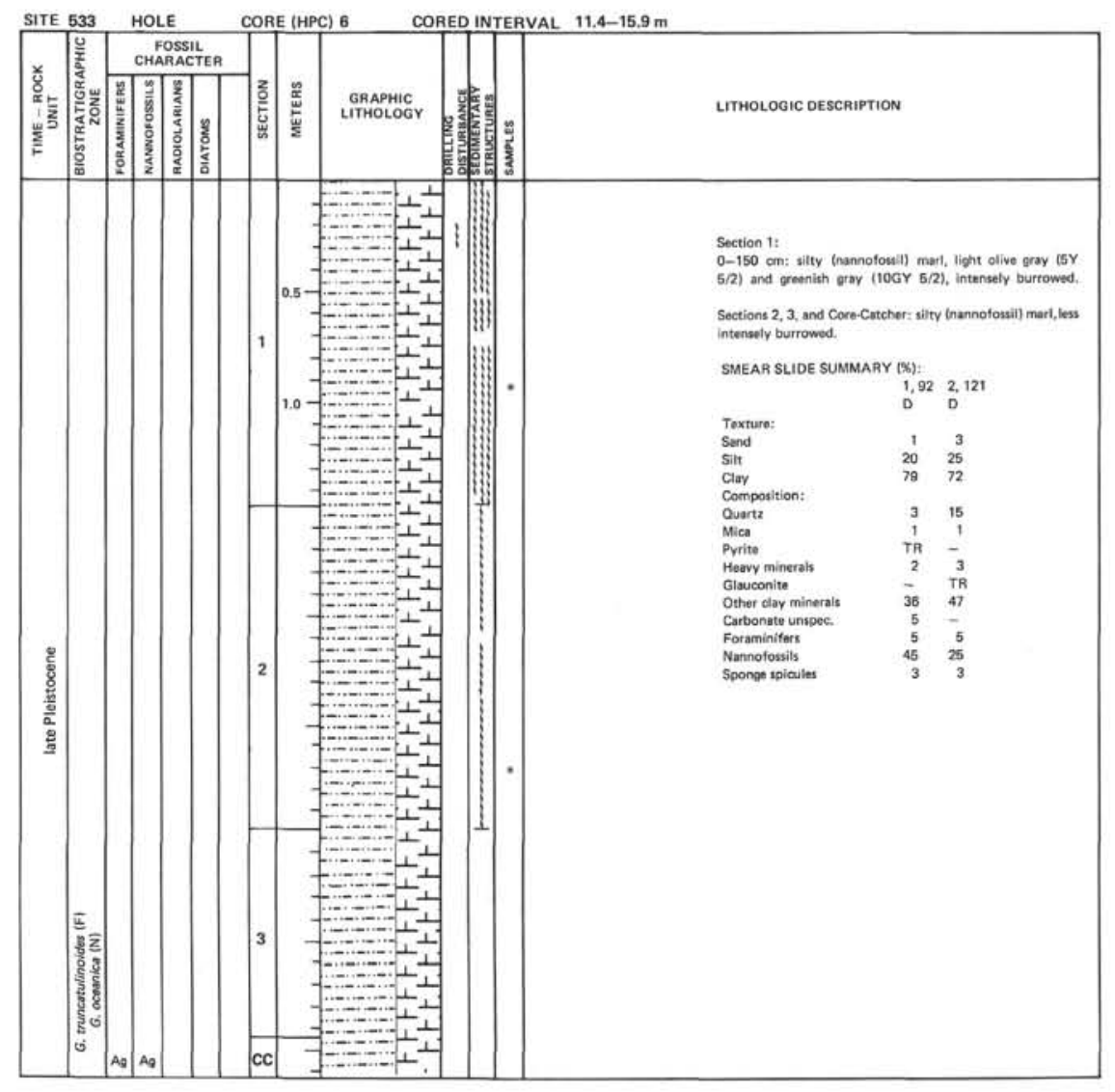

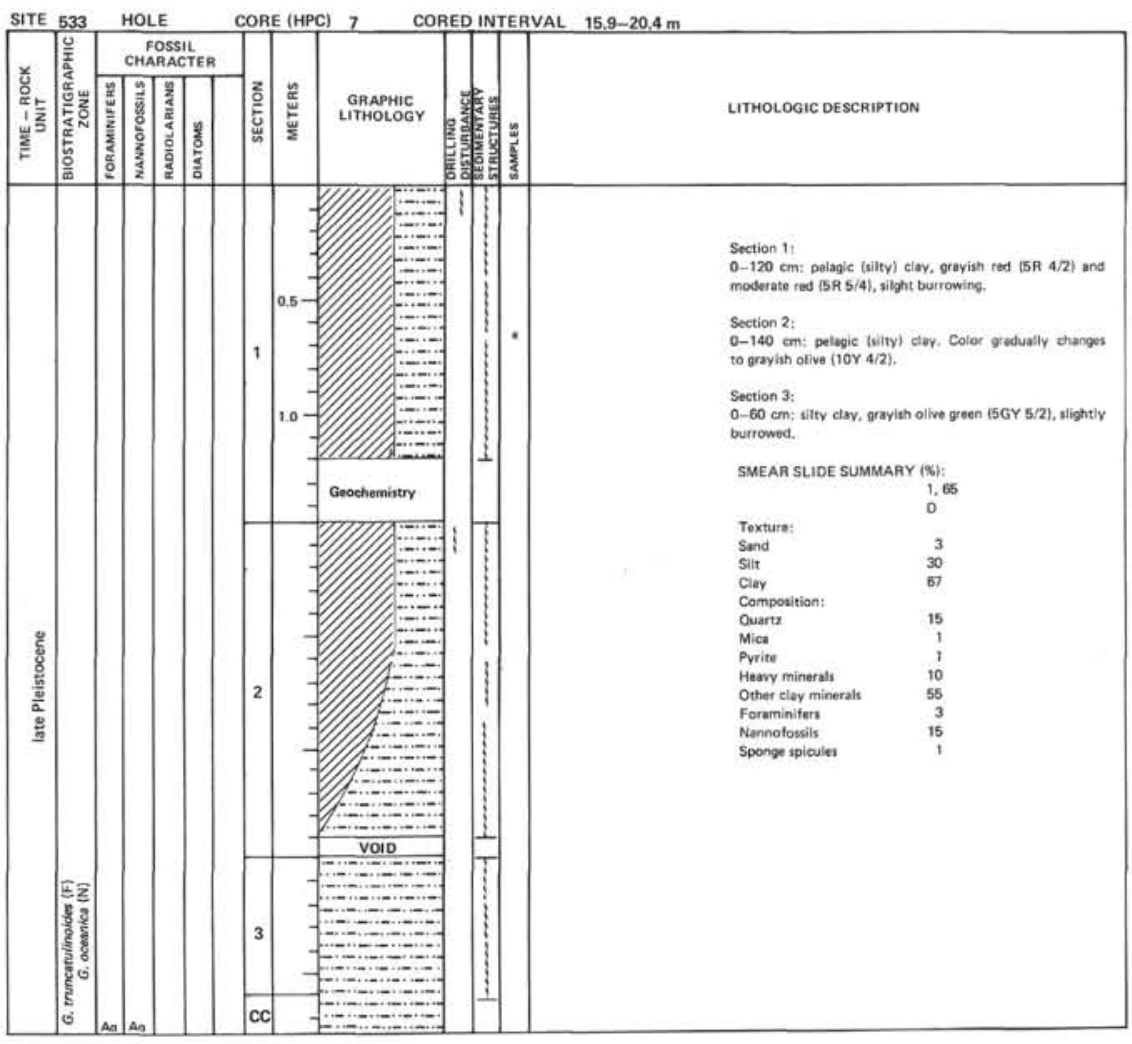



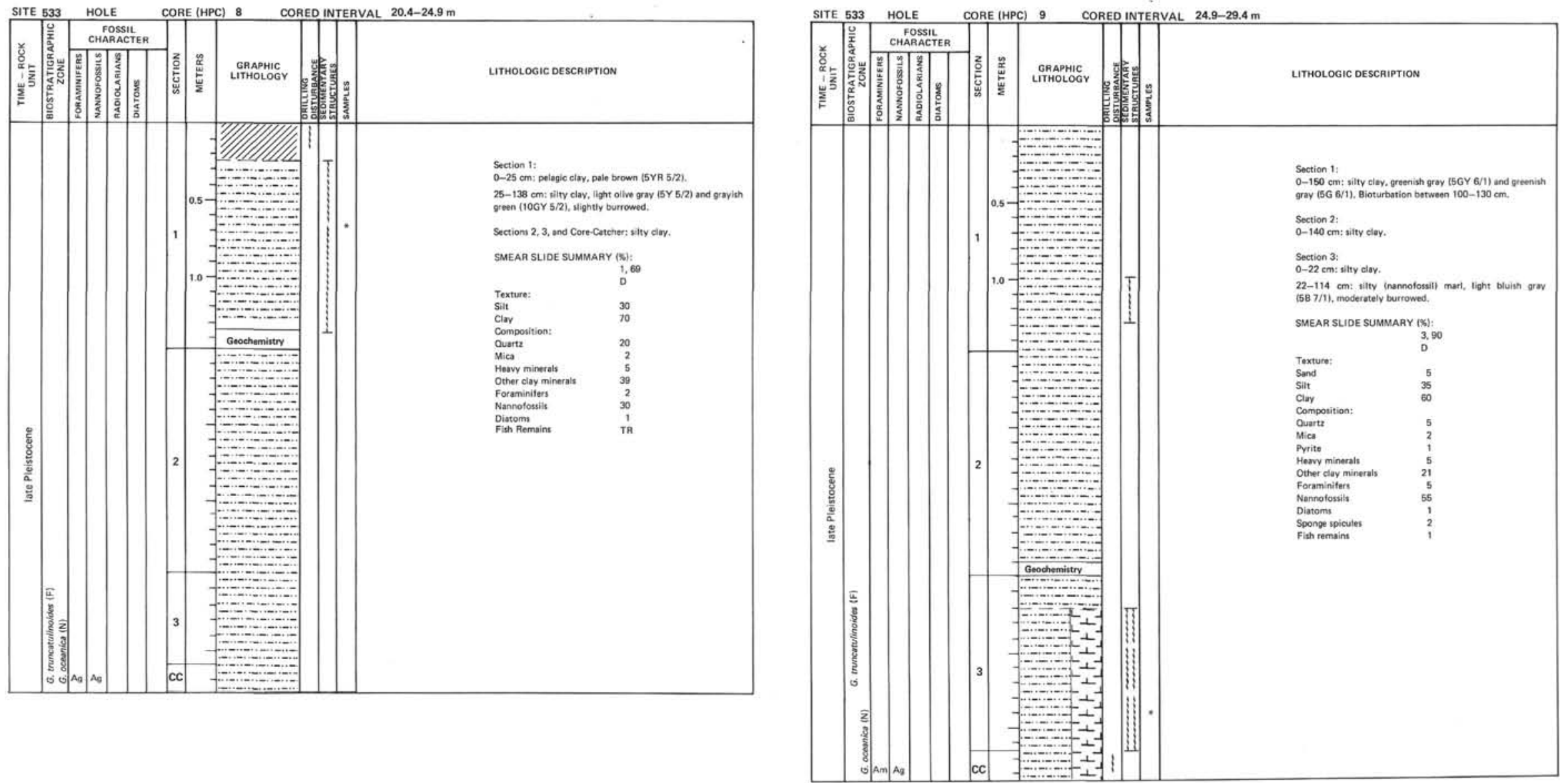


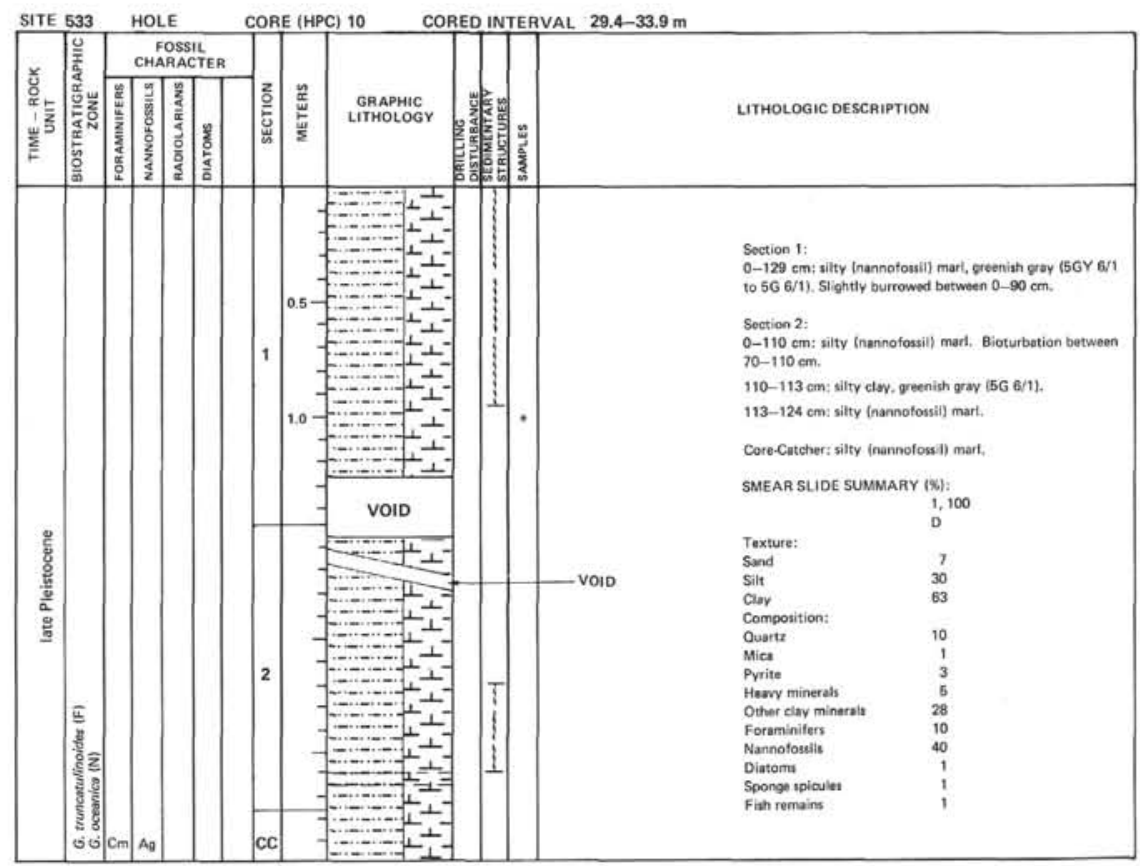

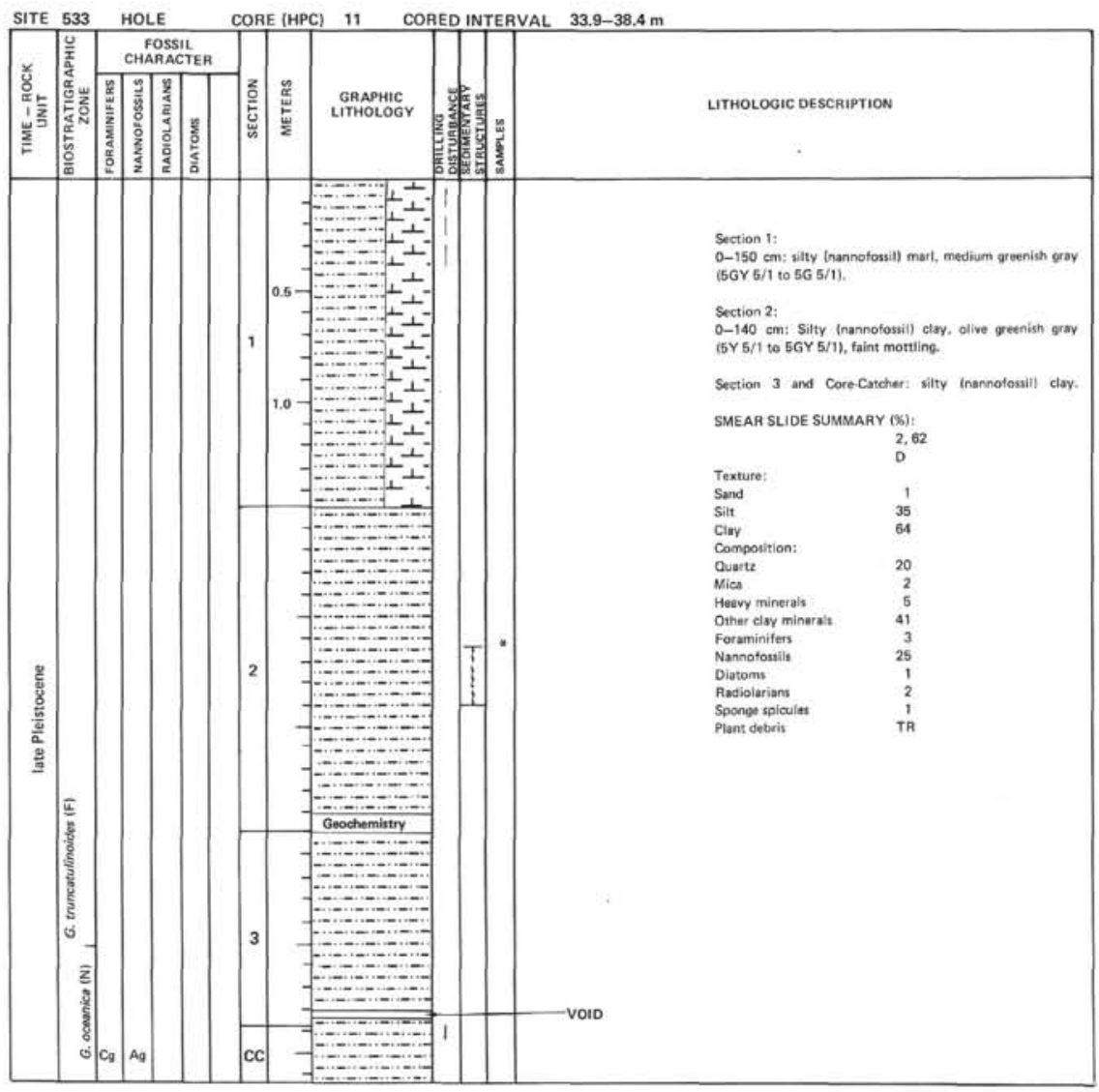




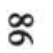

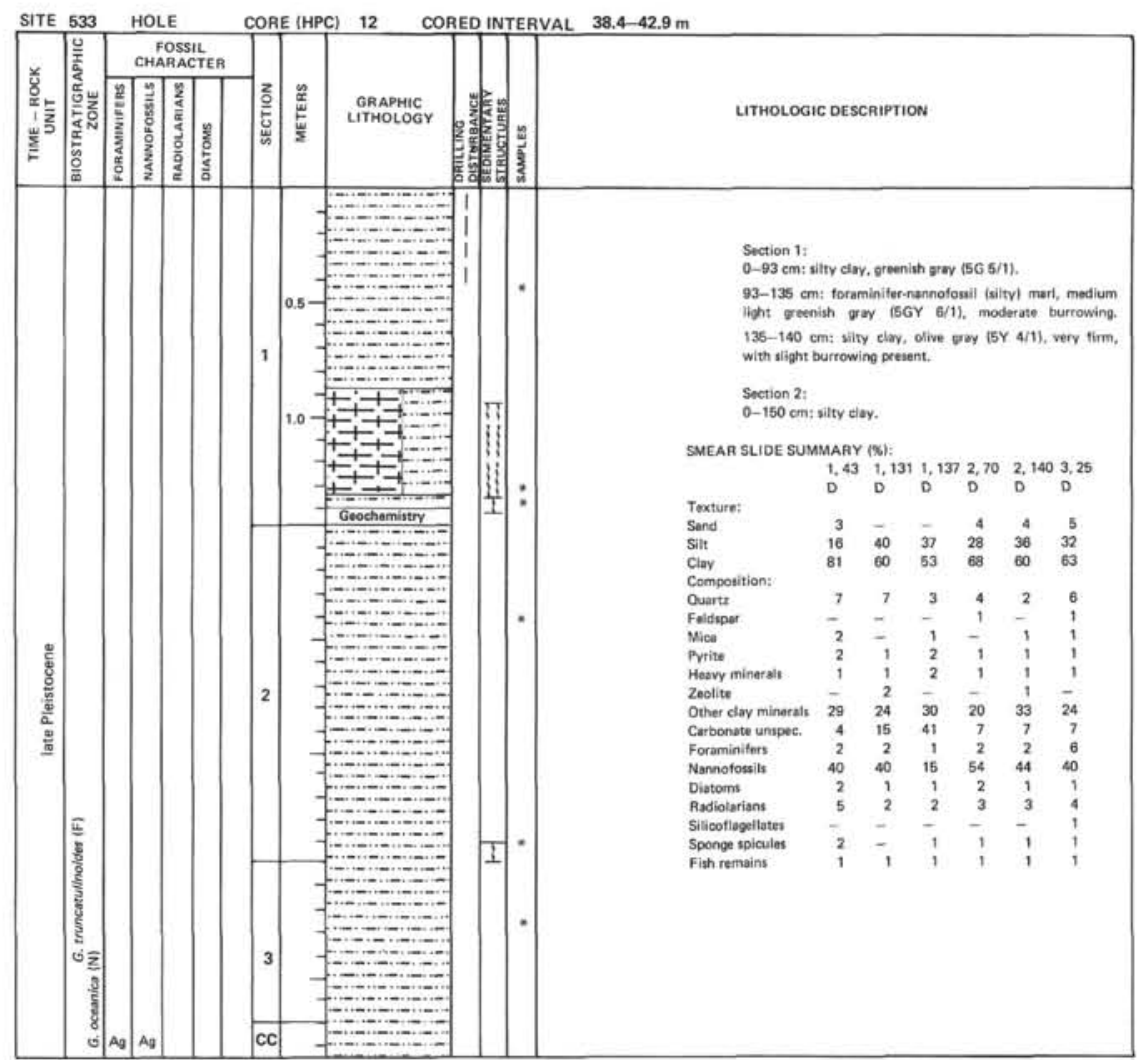

SITE 533 HOLE CORE (HPC) 13 CORED INTERVAL $42.9-47.0 \mathrm{~m}$

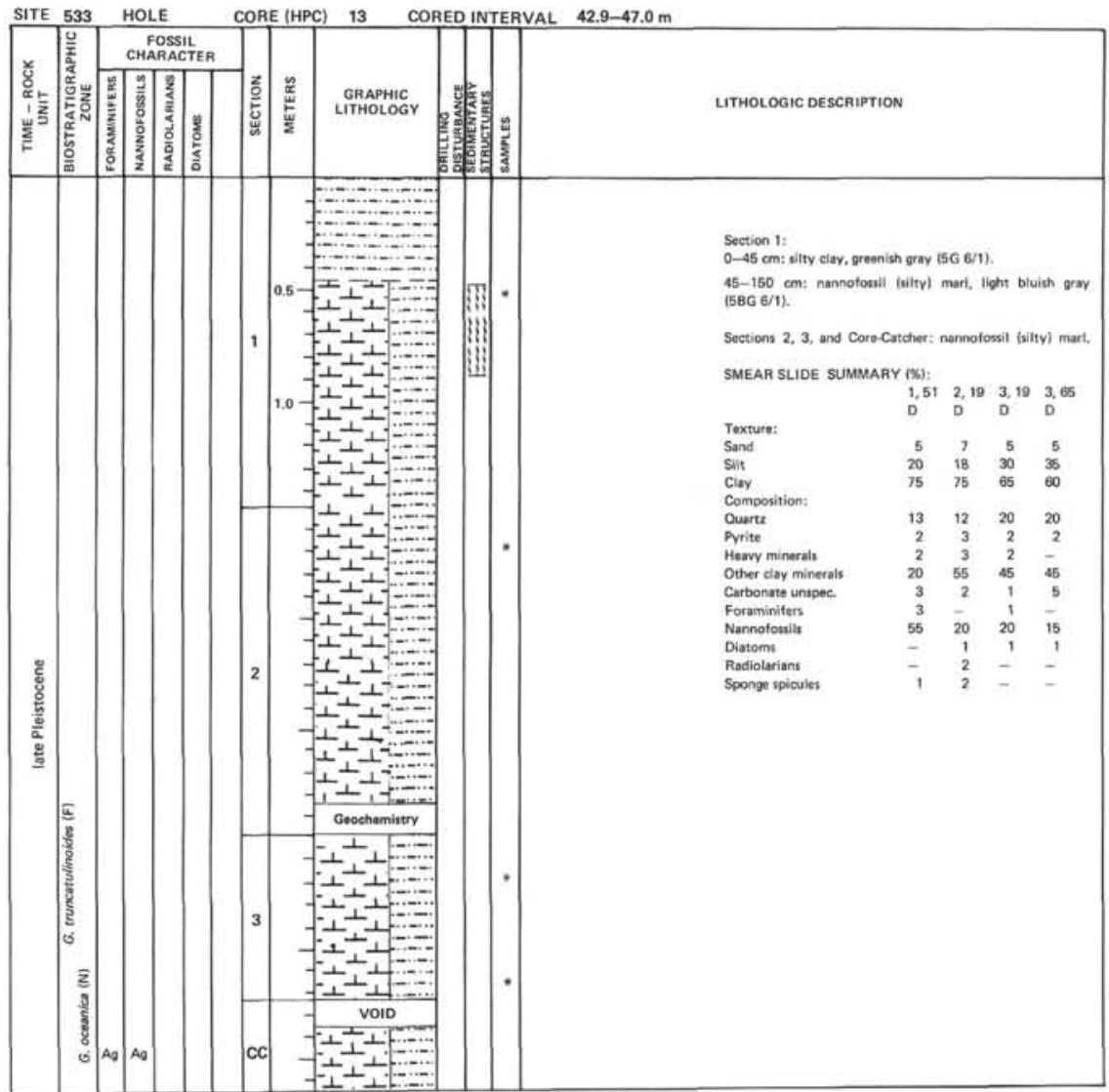

藏 


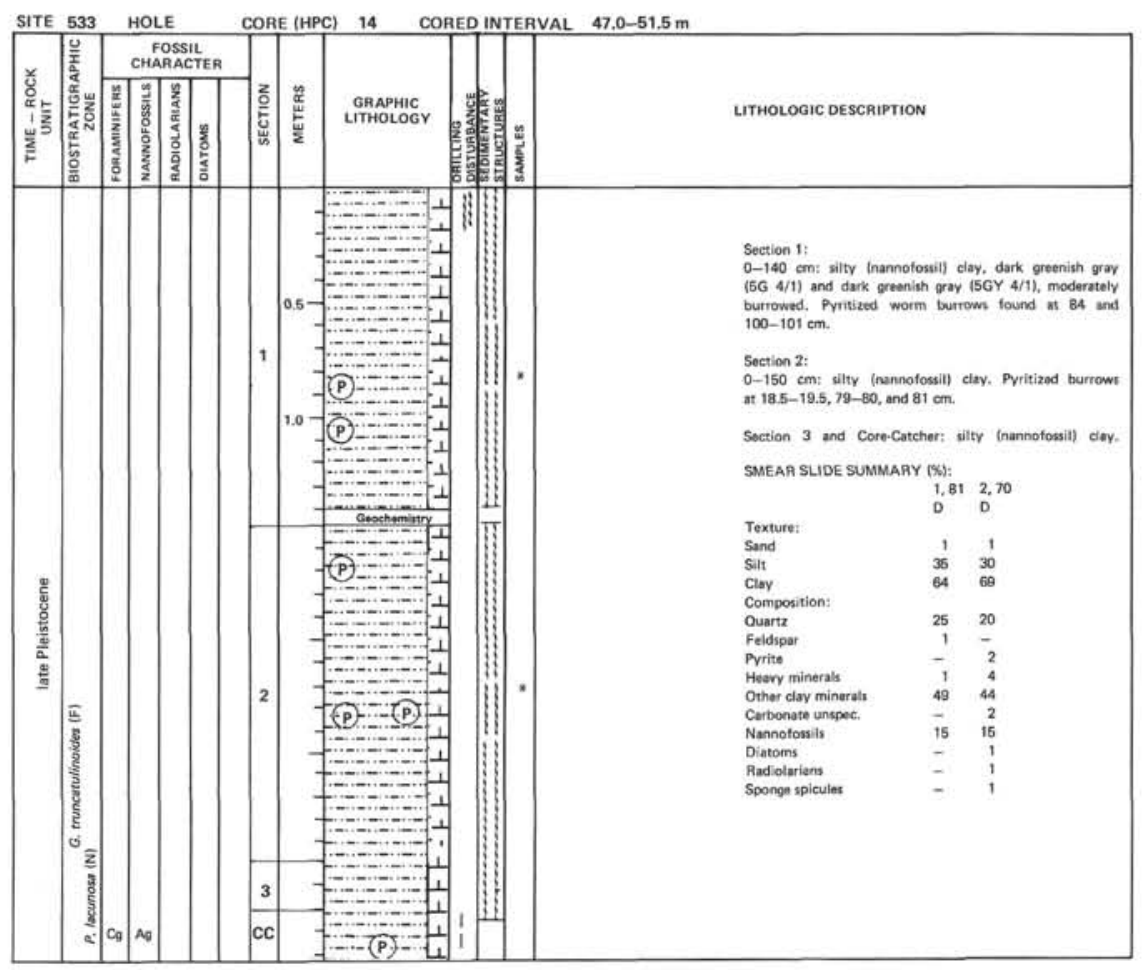

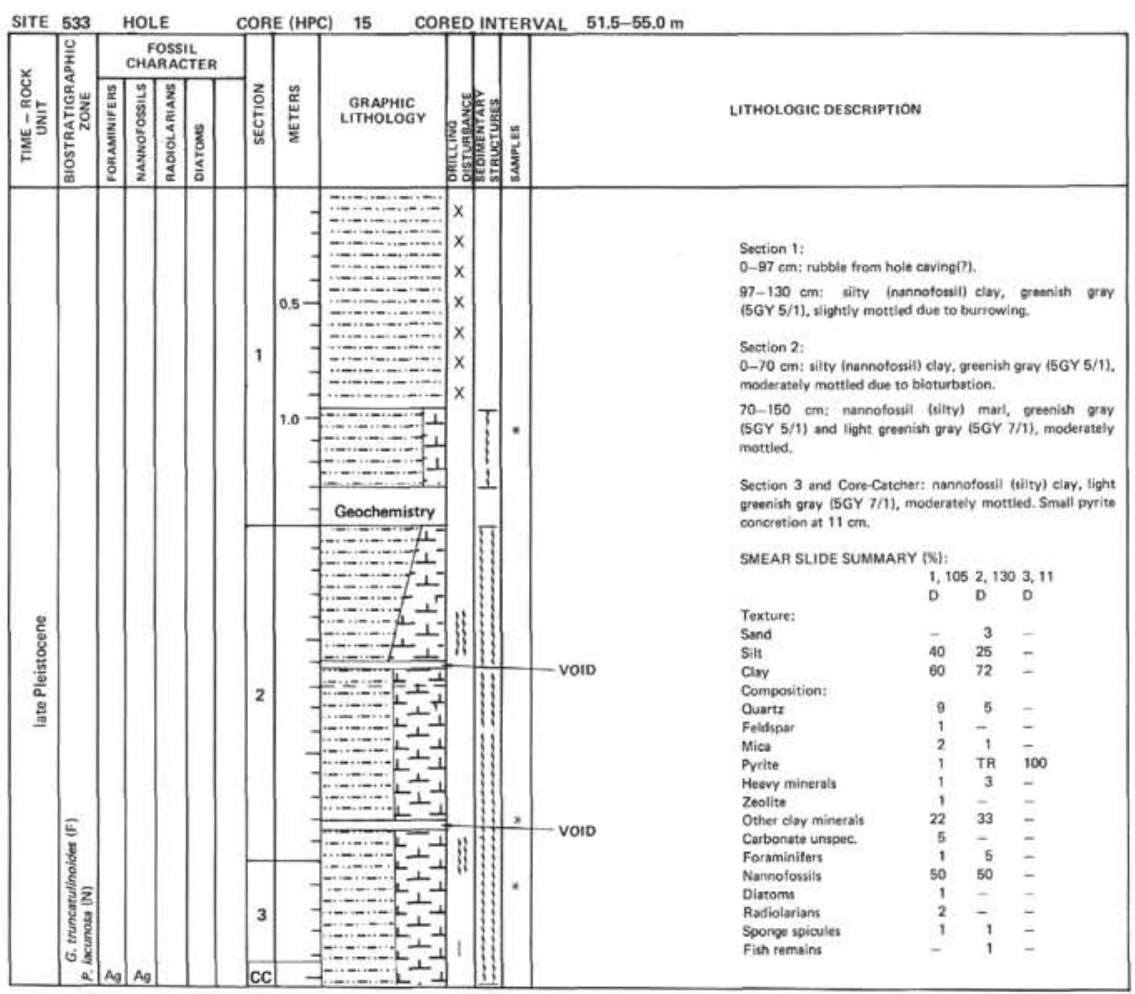




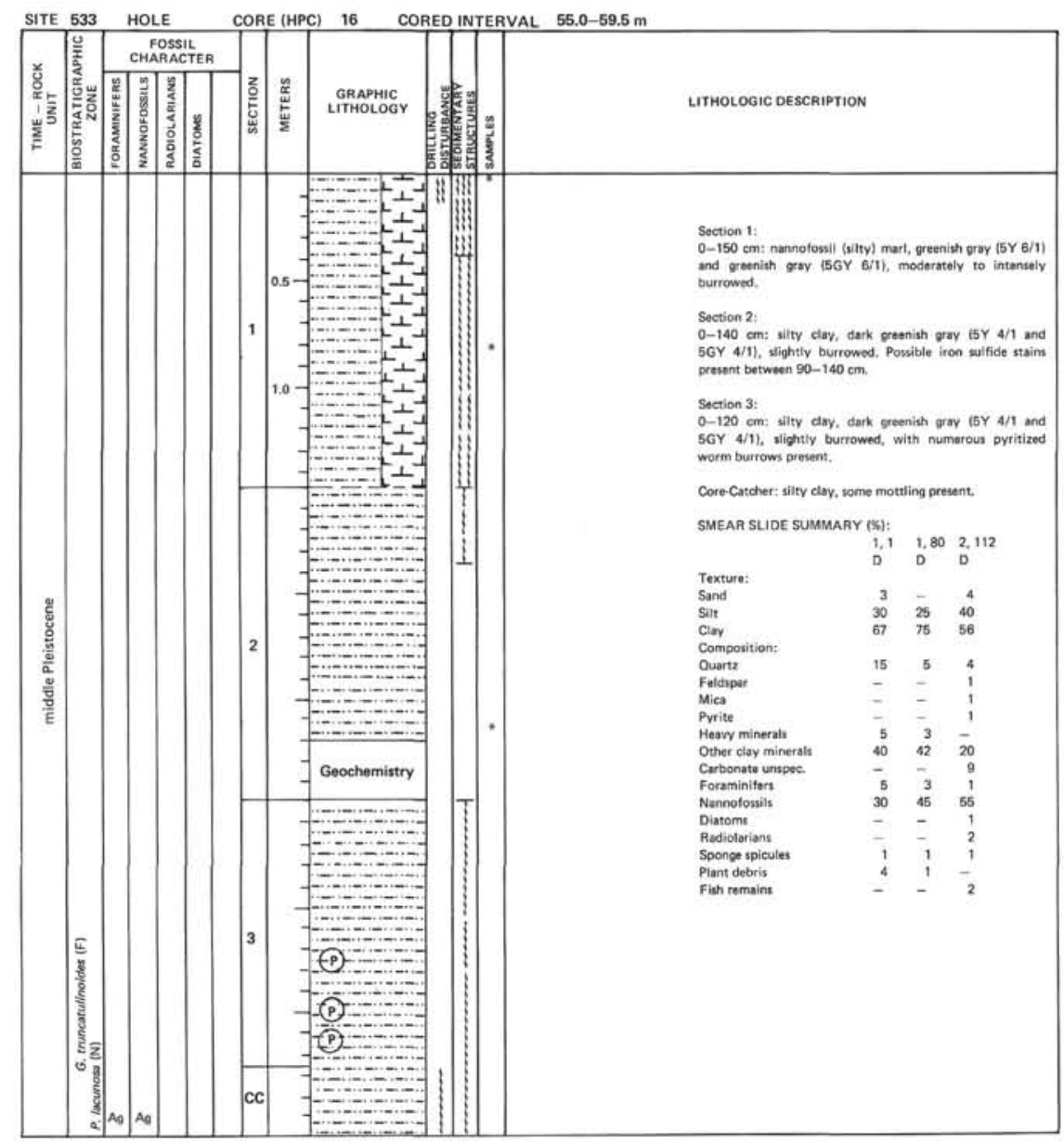

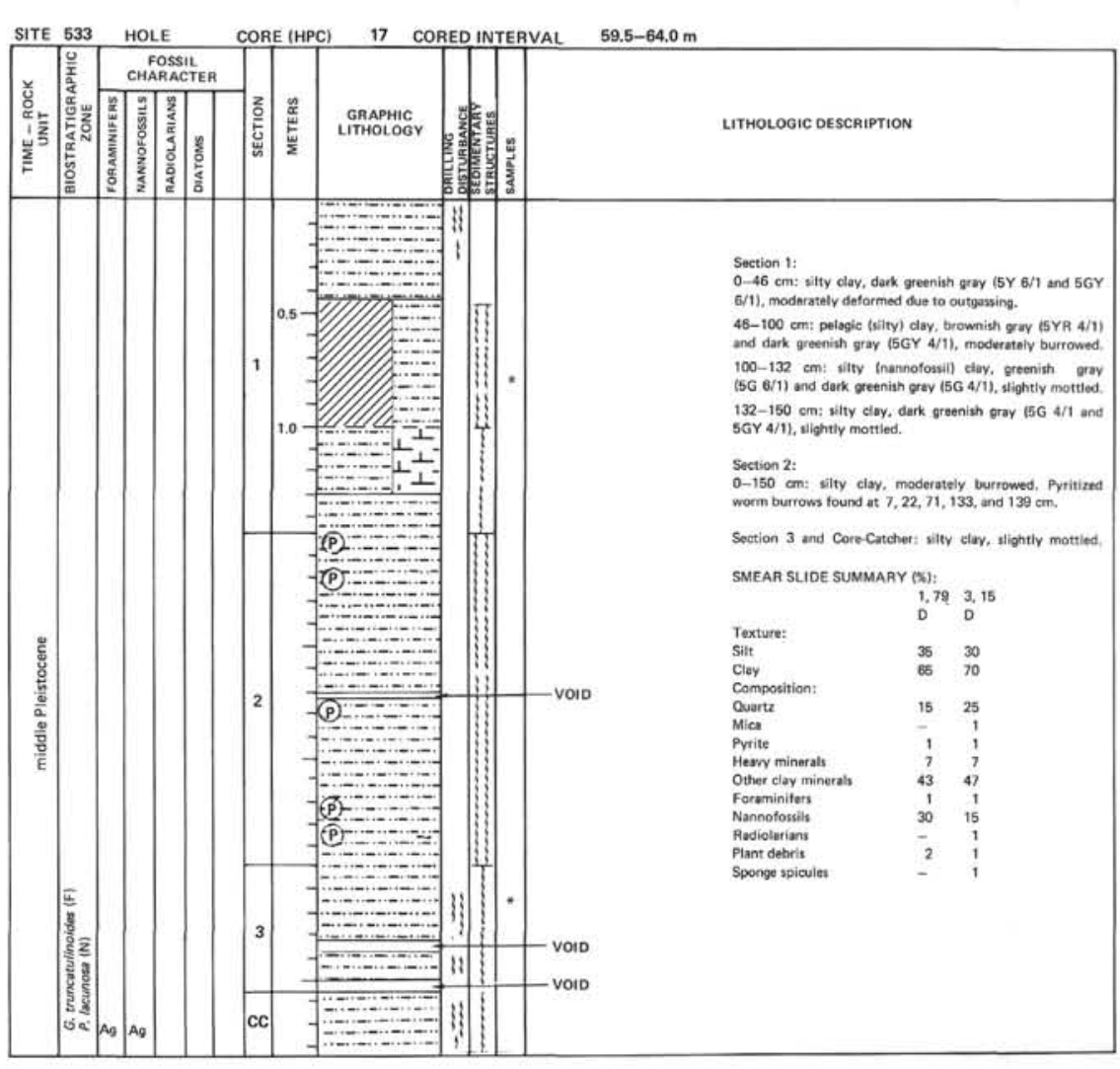




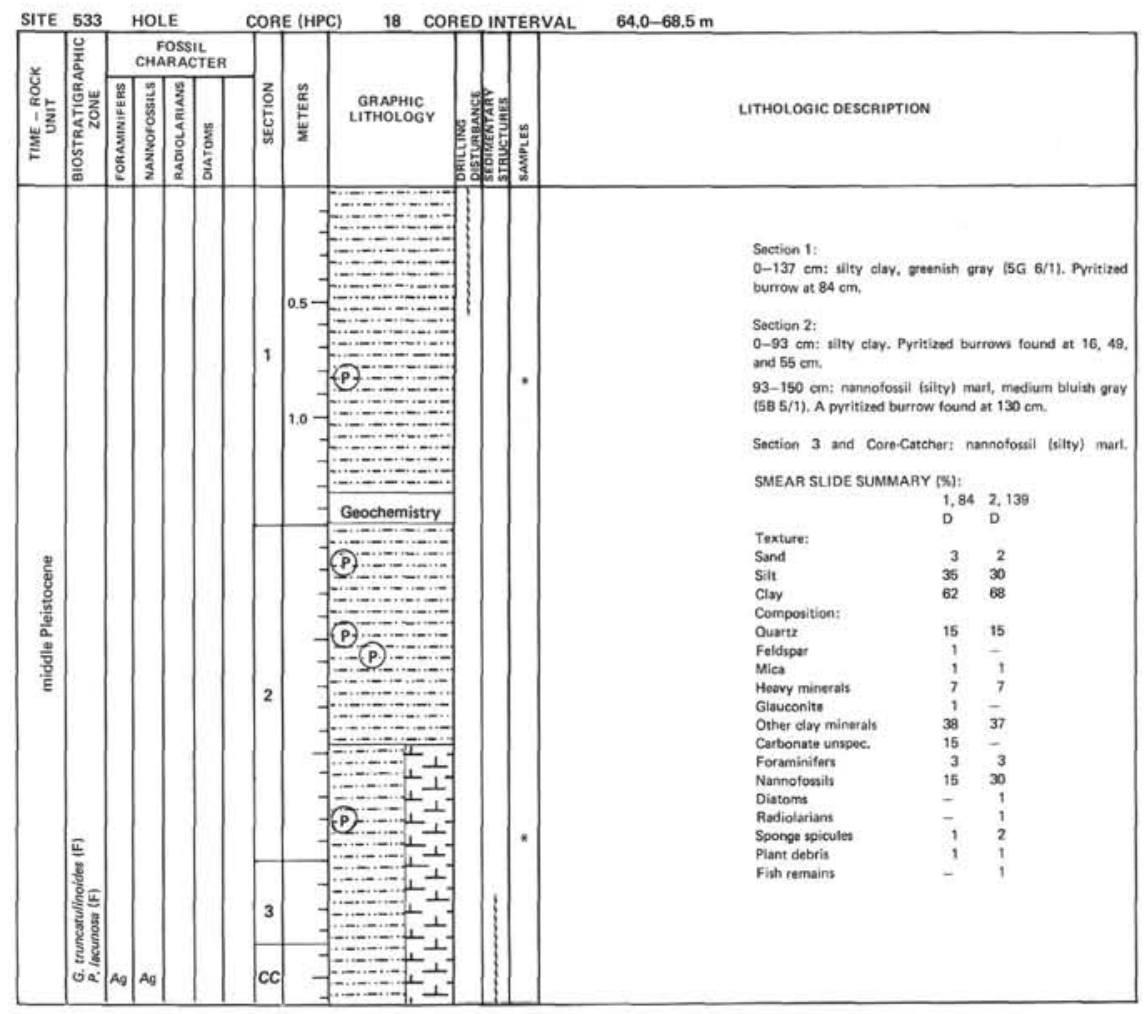

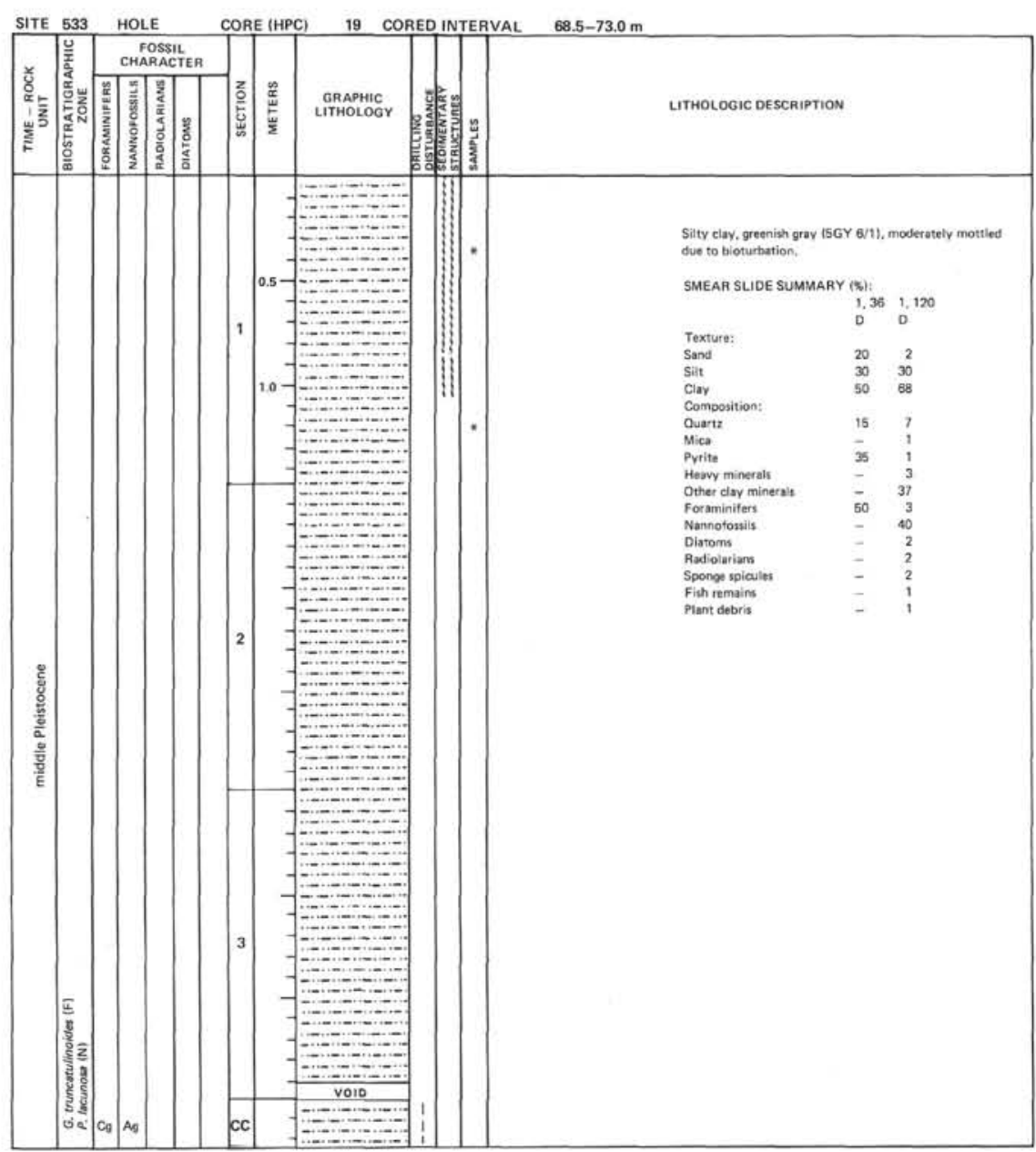



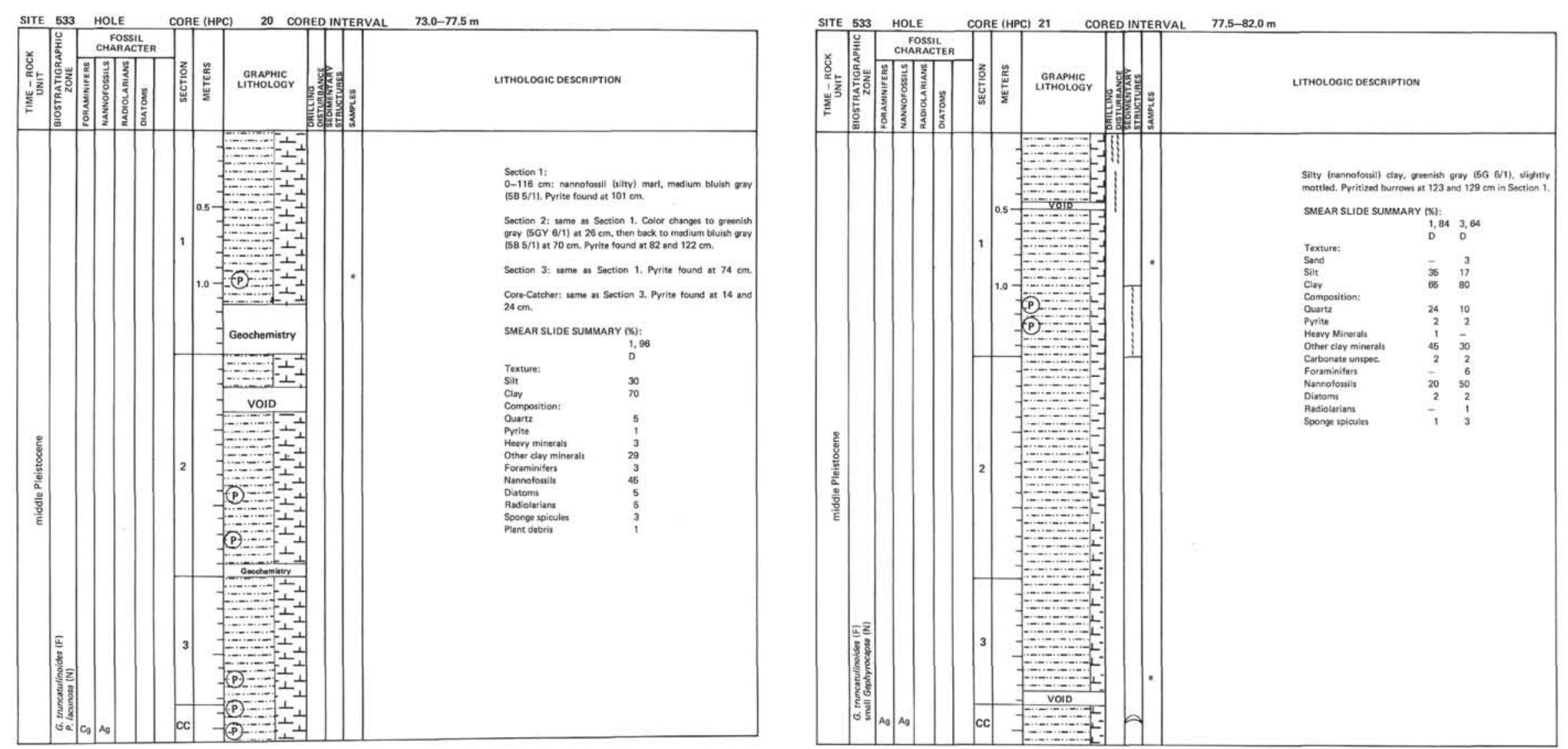


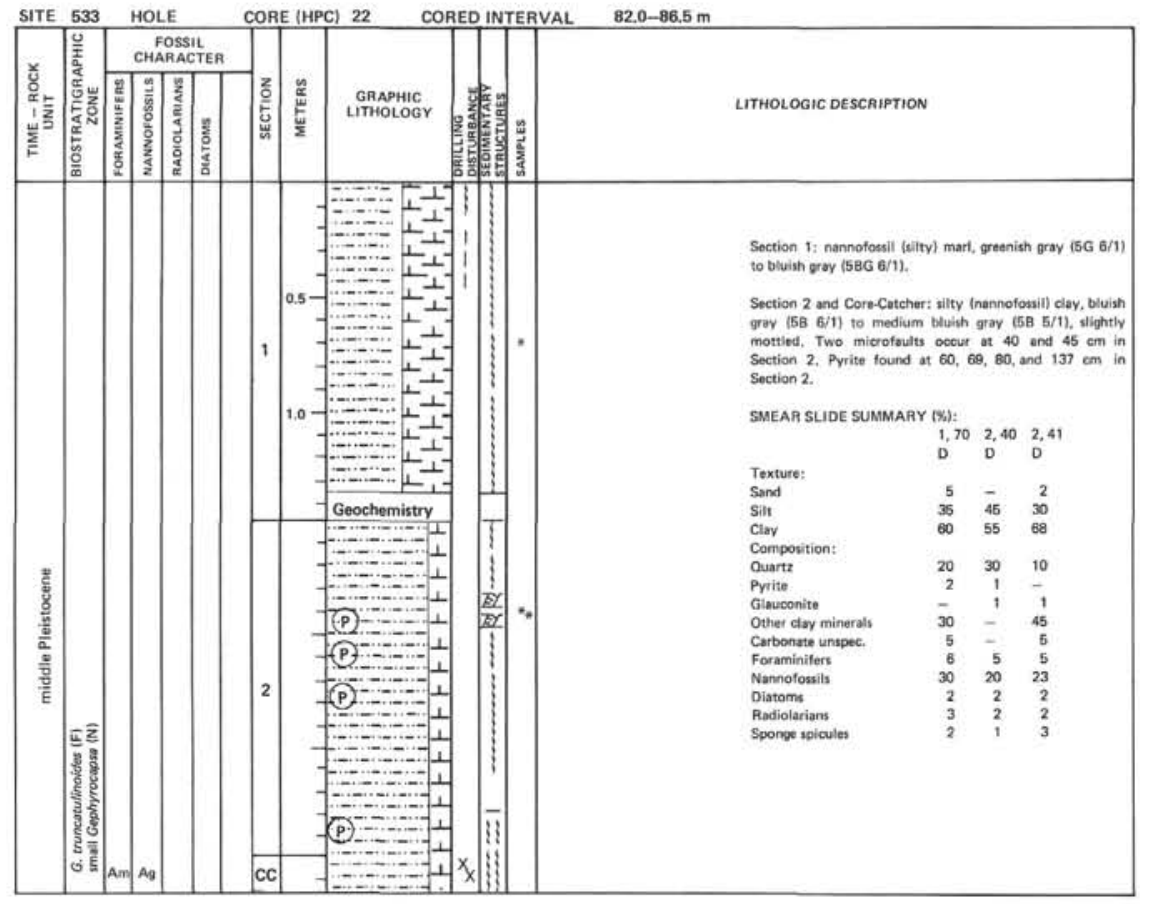

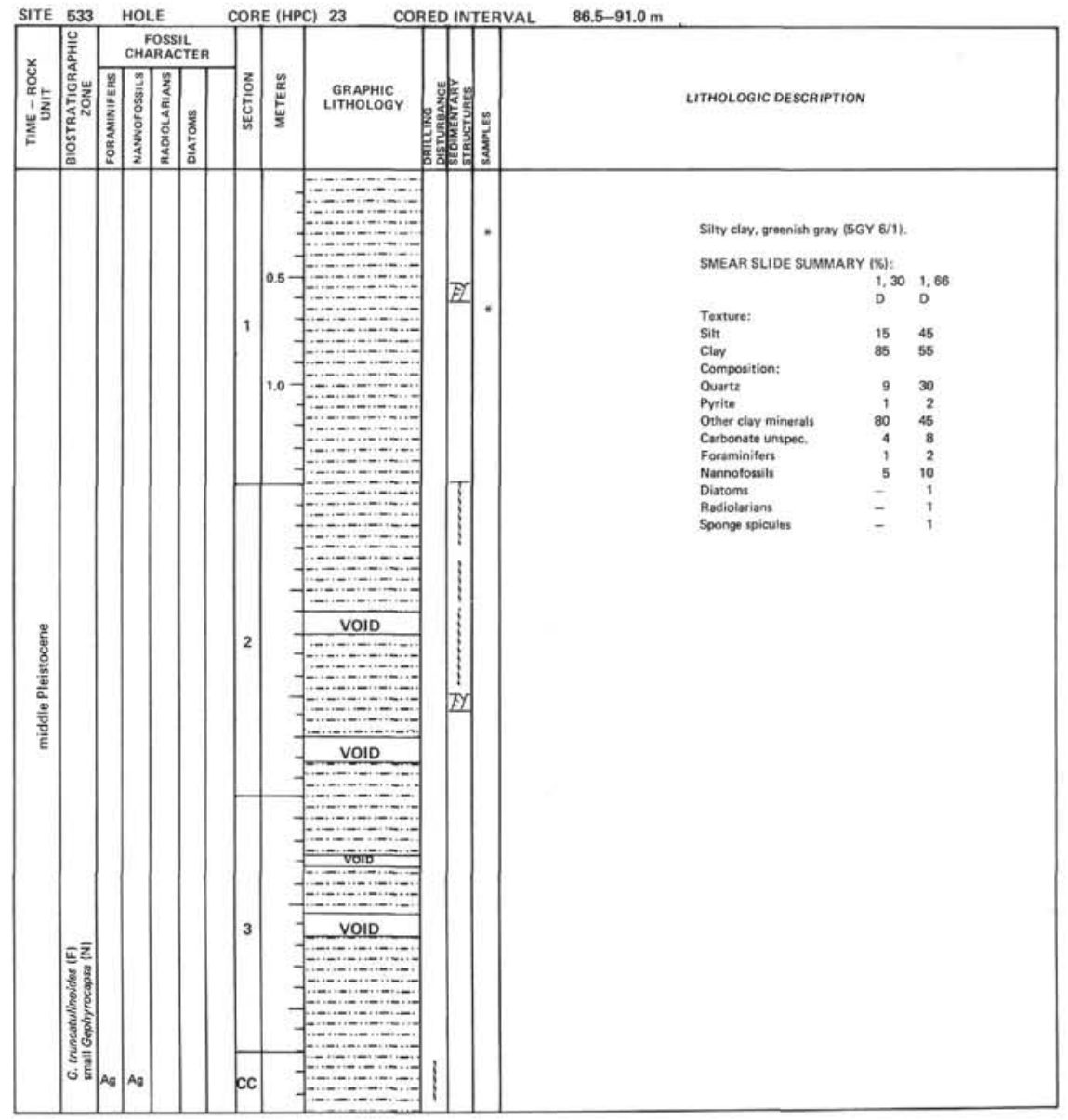



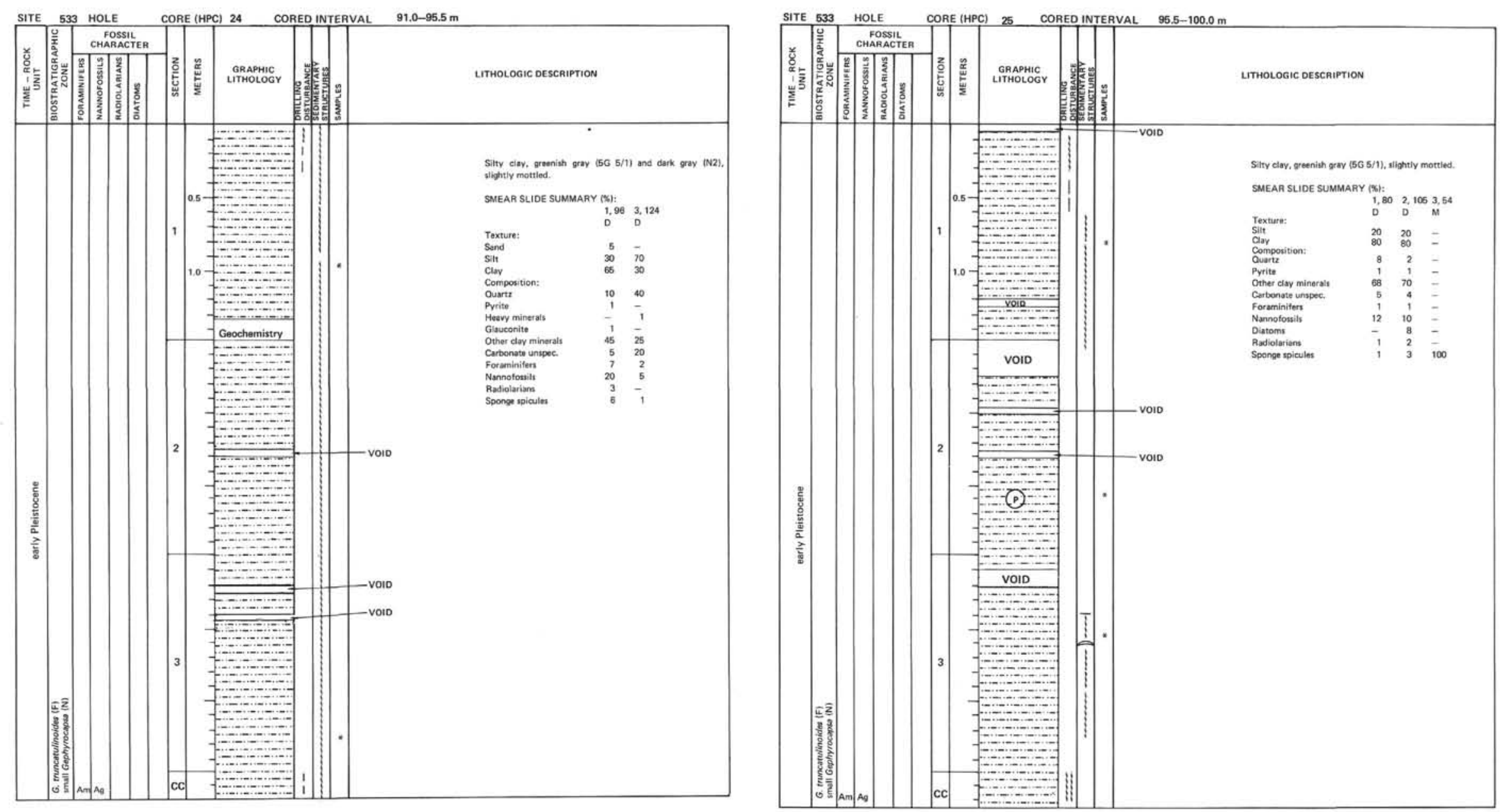


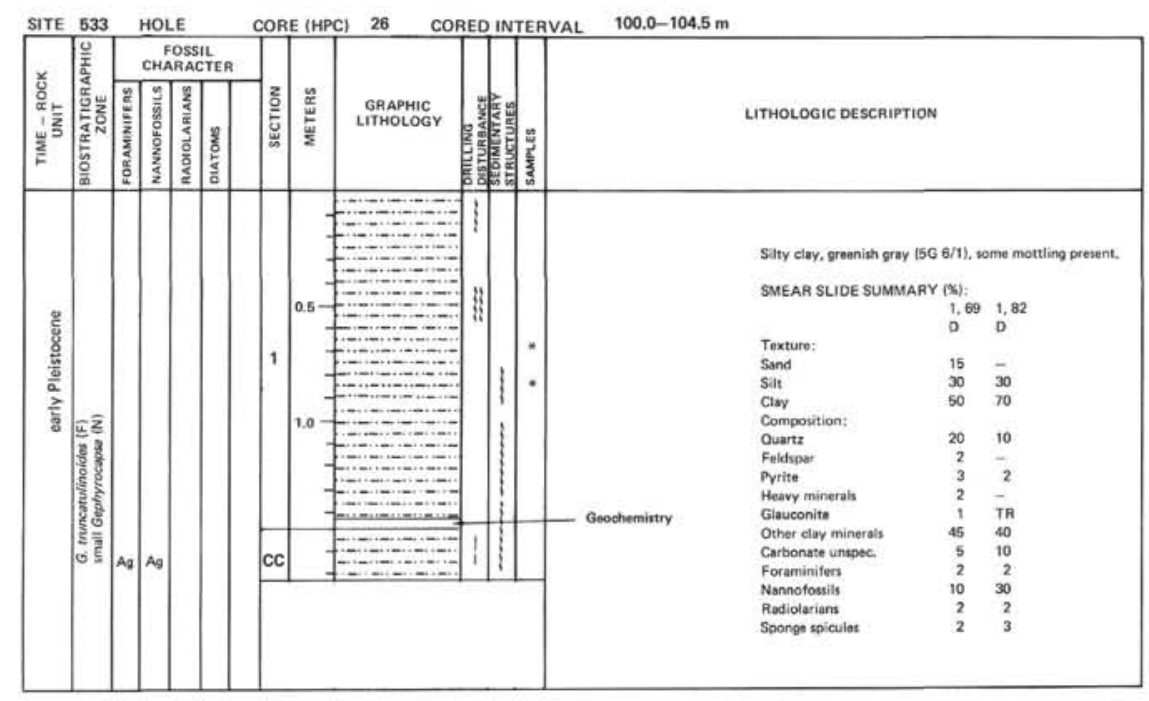

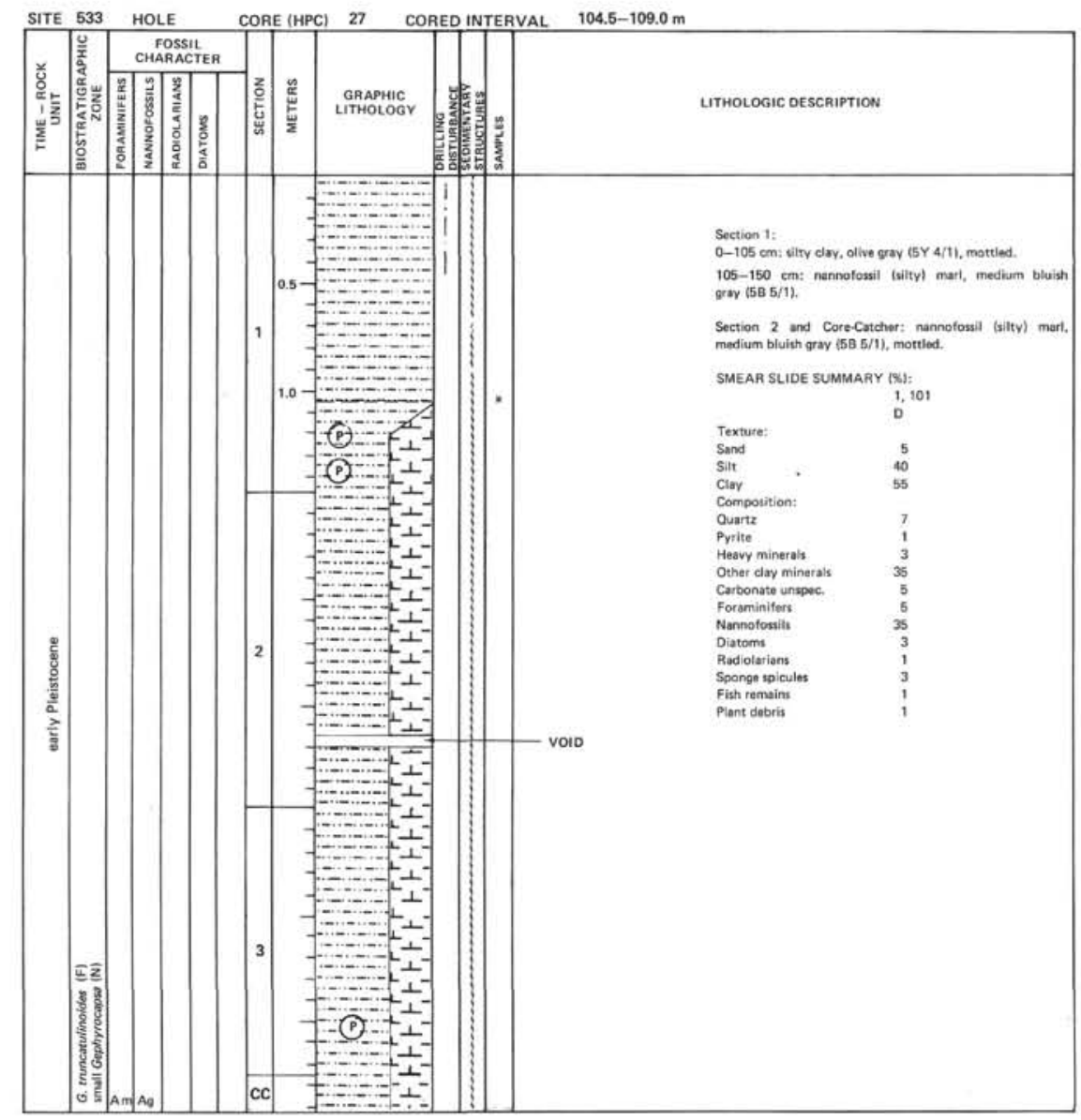



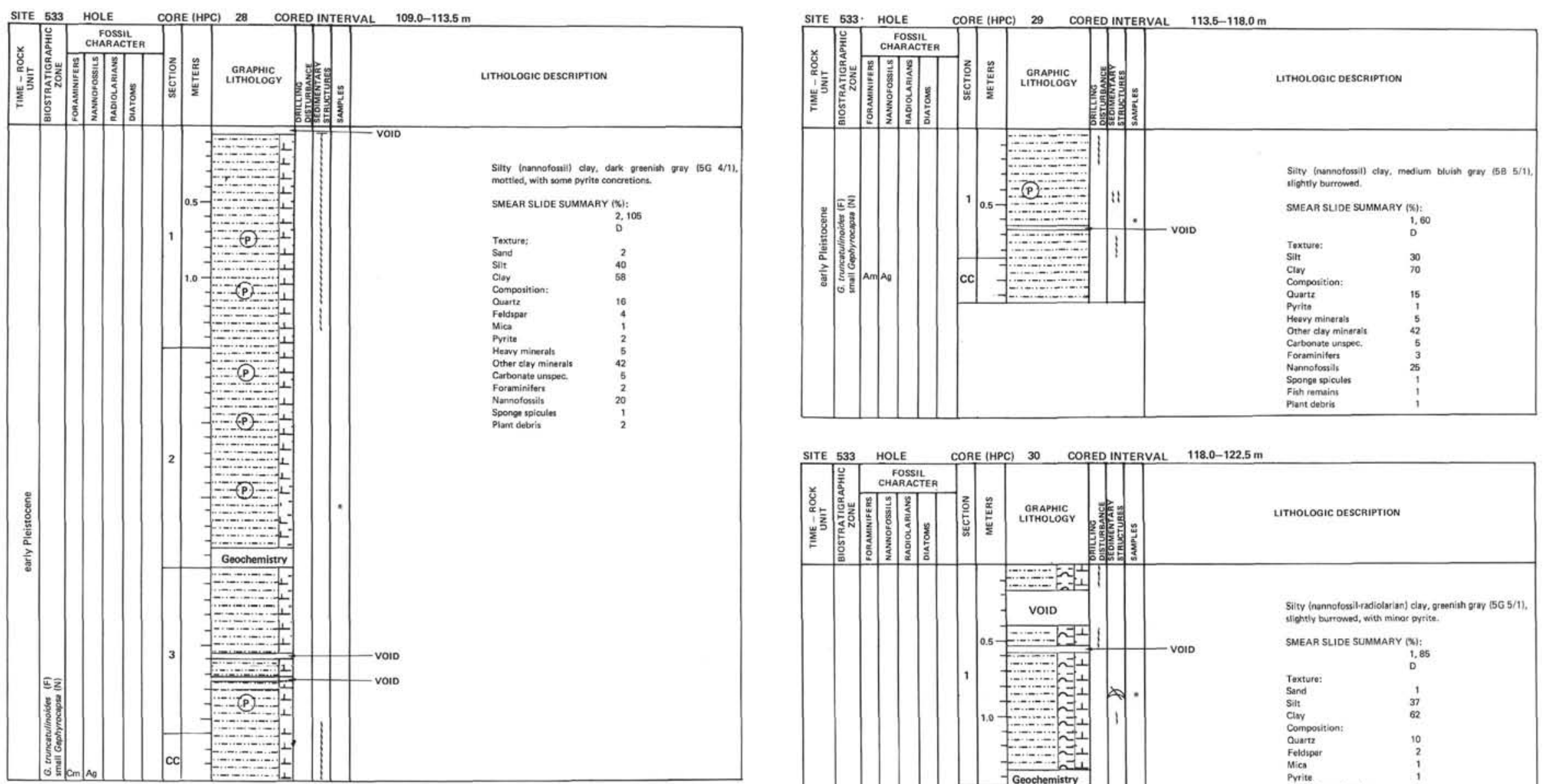

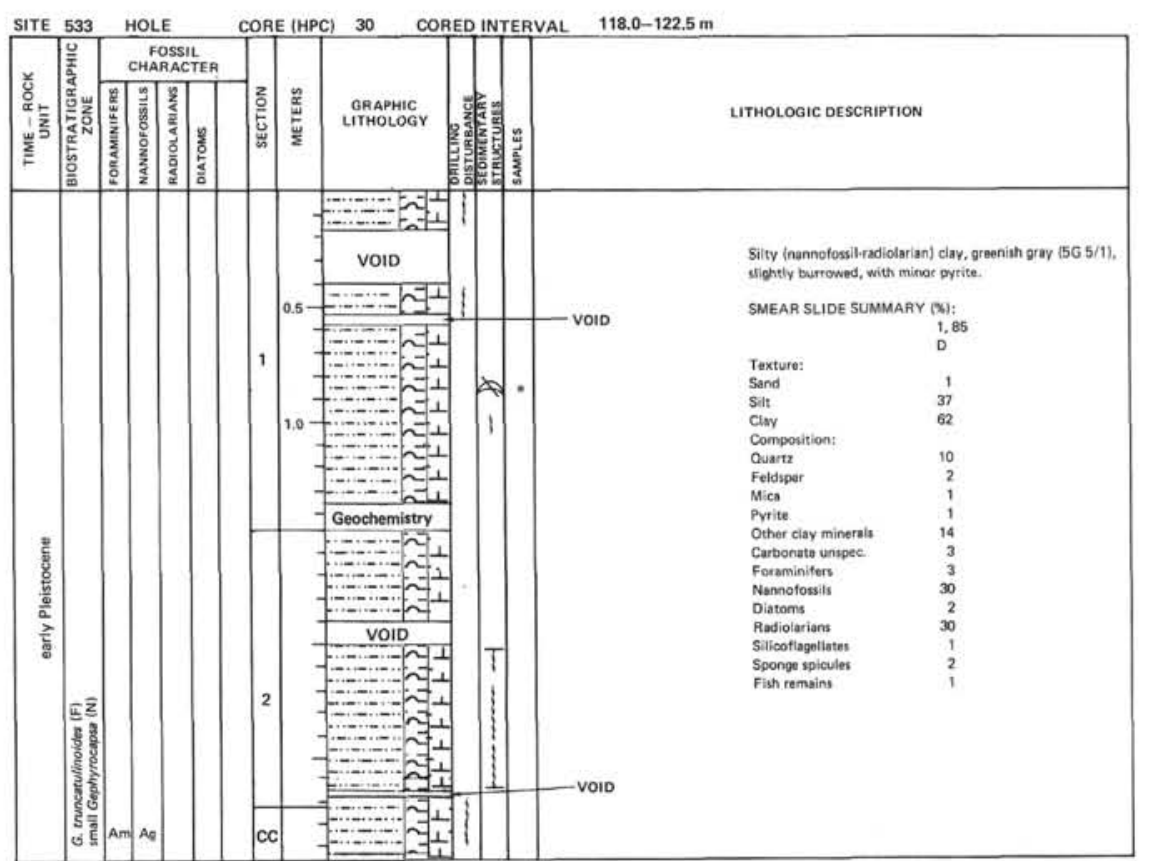



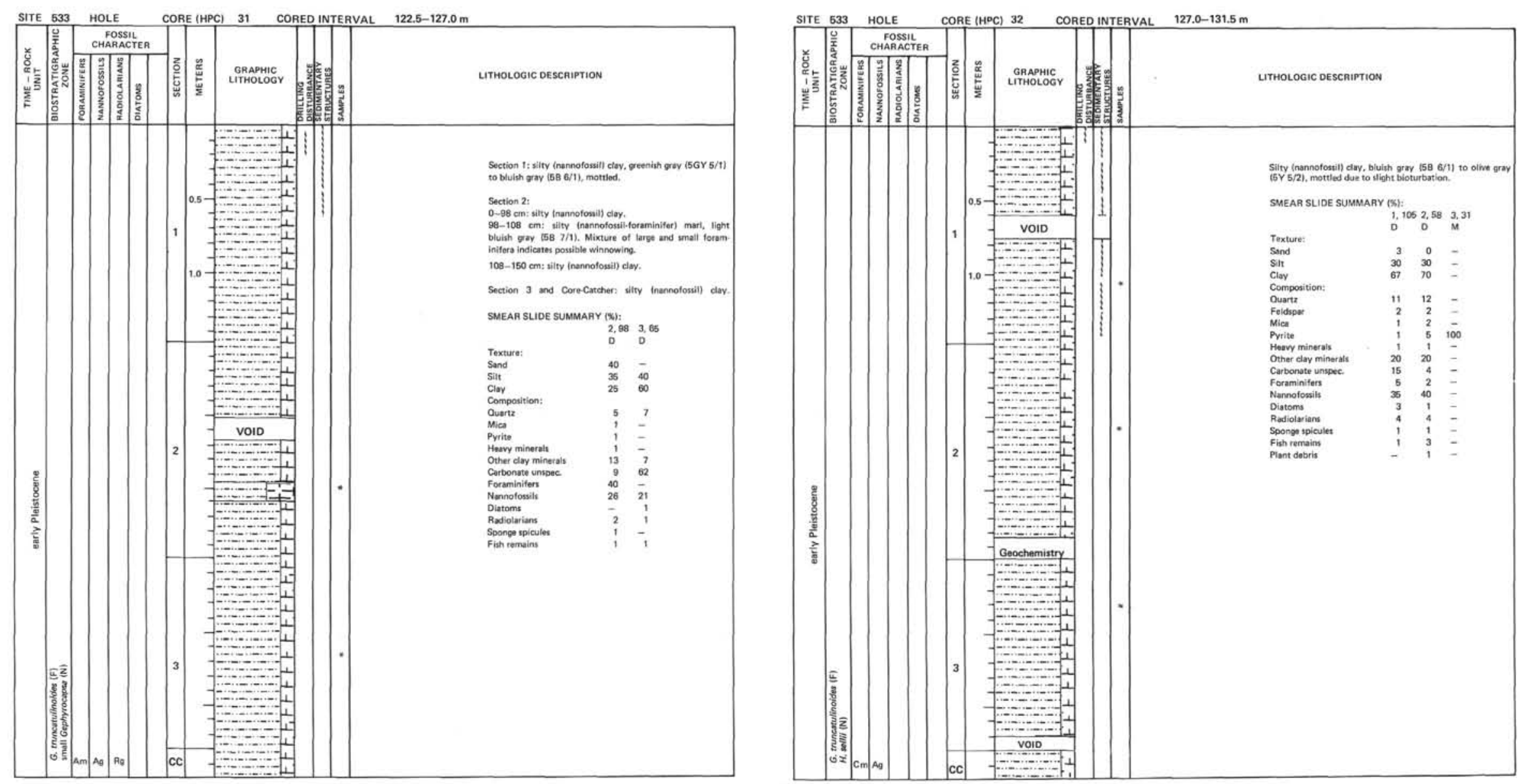
๖

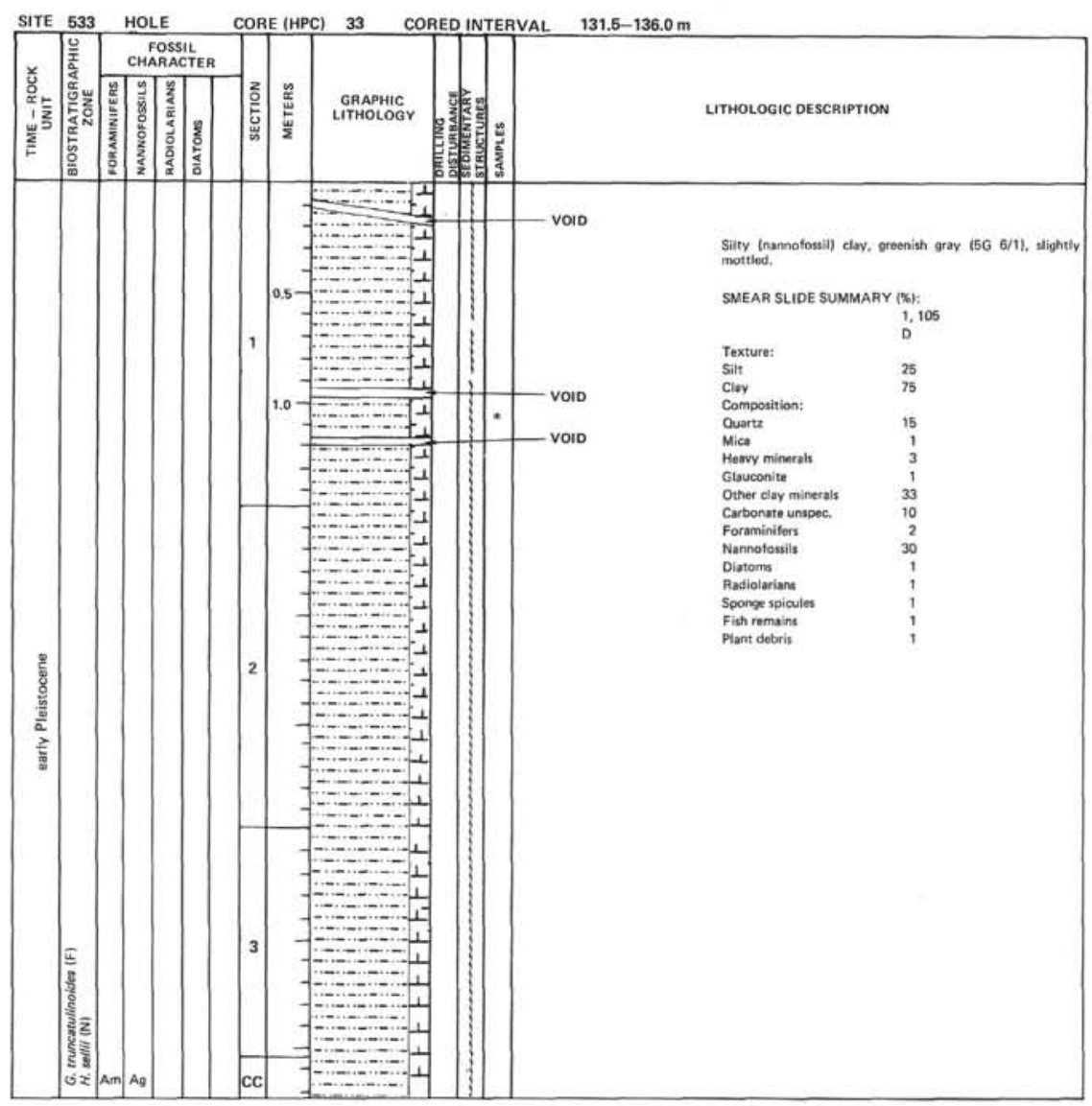

SITE 533 HOLE CORE (HPC) 34 CORED INTERVAL $136.0-140.5 \mathrm{~m}$

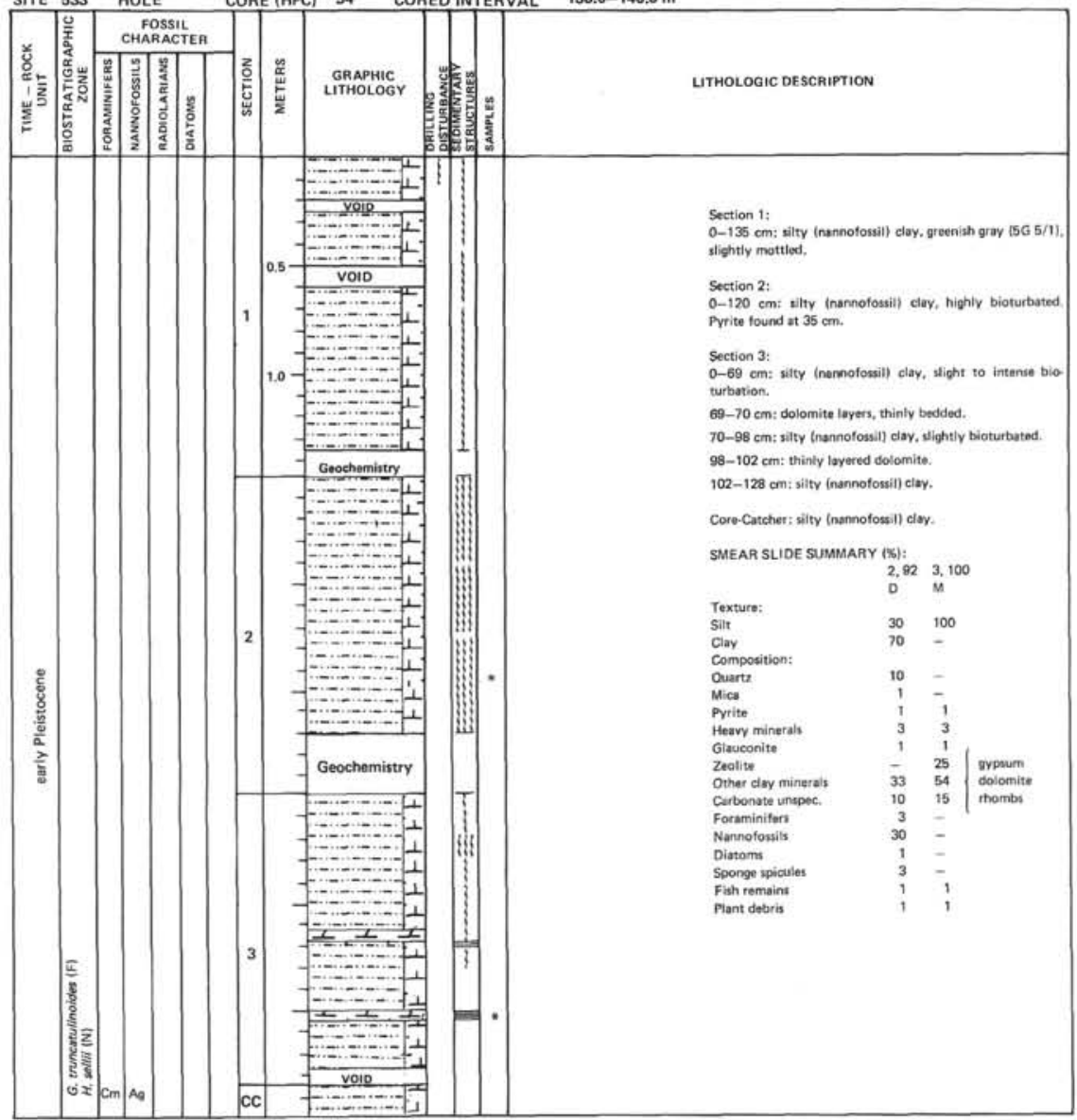



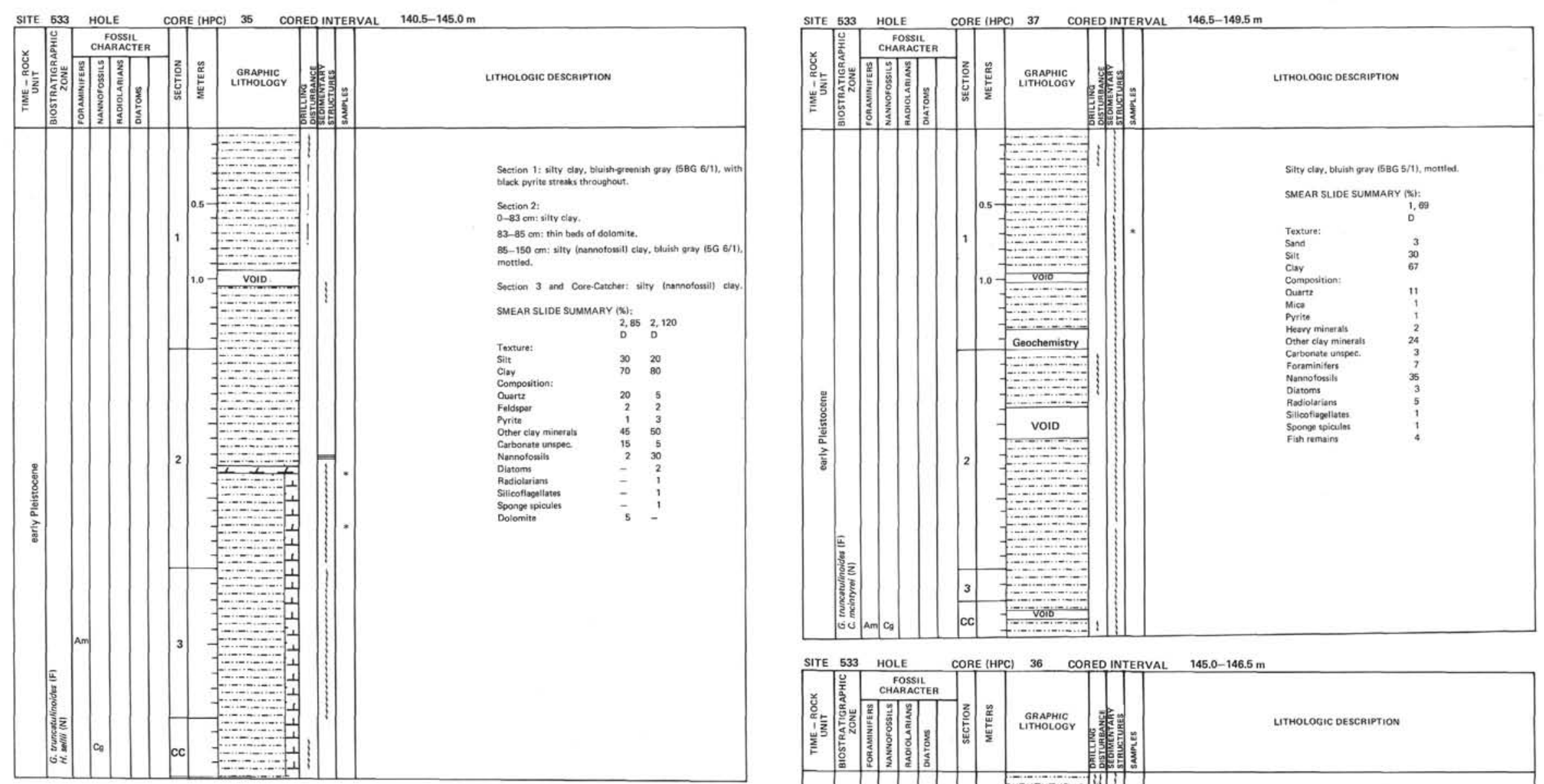

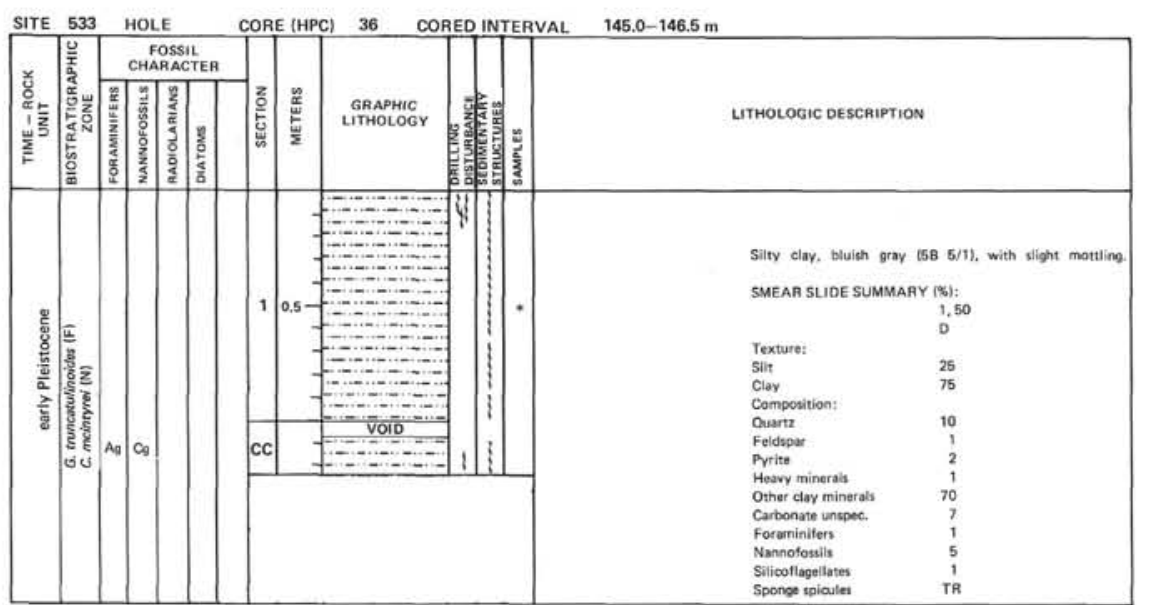




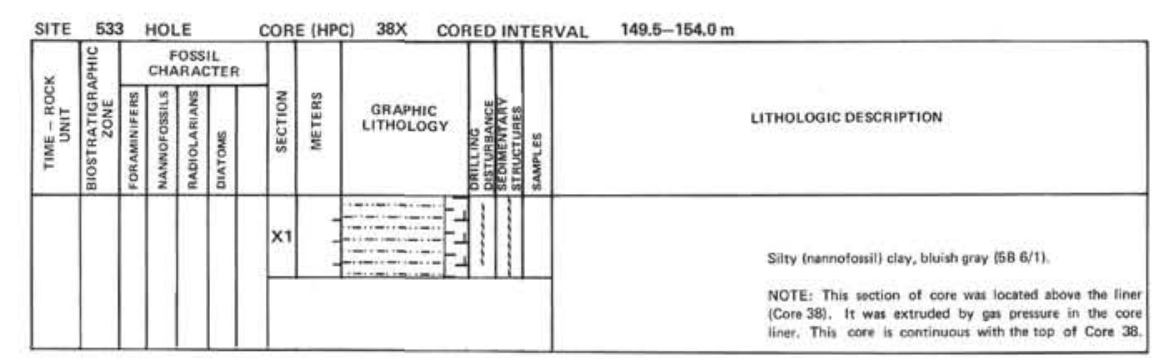

SITE 533 HOLE CORE (HPC) 39 CORED INTERVAL $154.0-158.5 \mathrm{~m}$
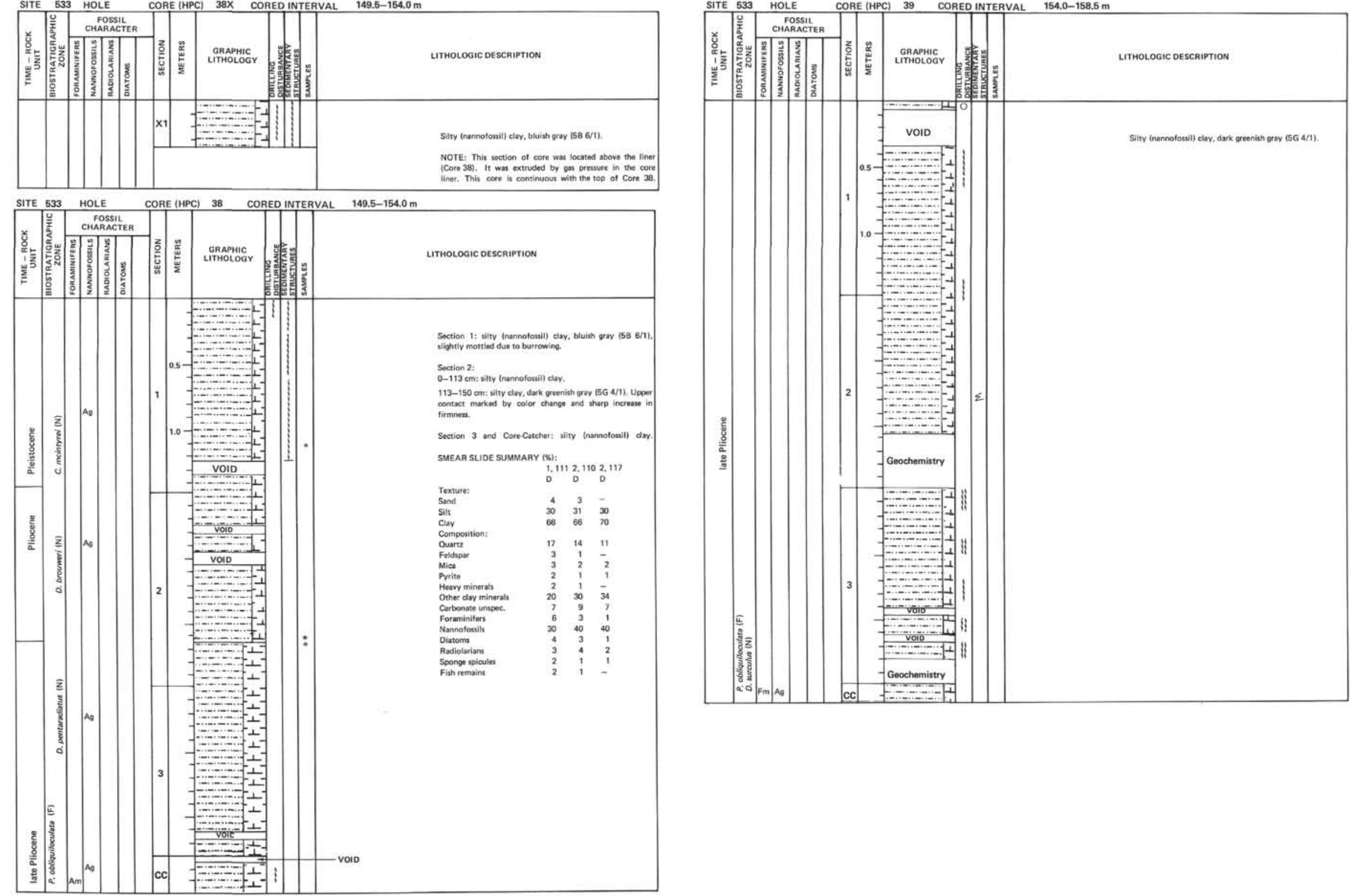

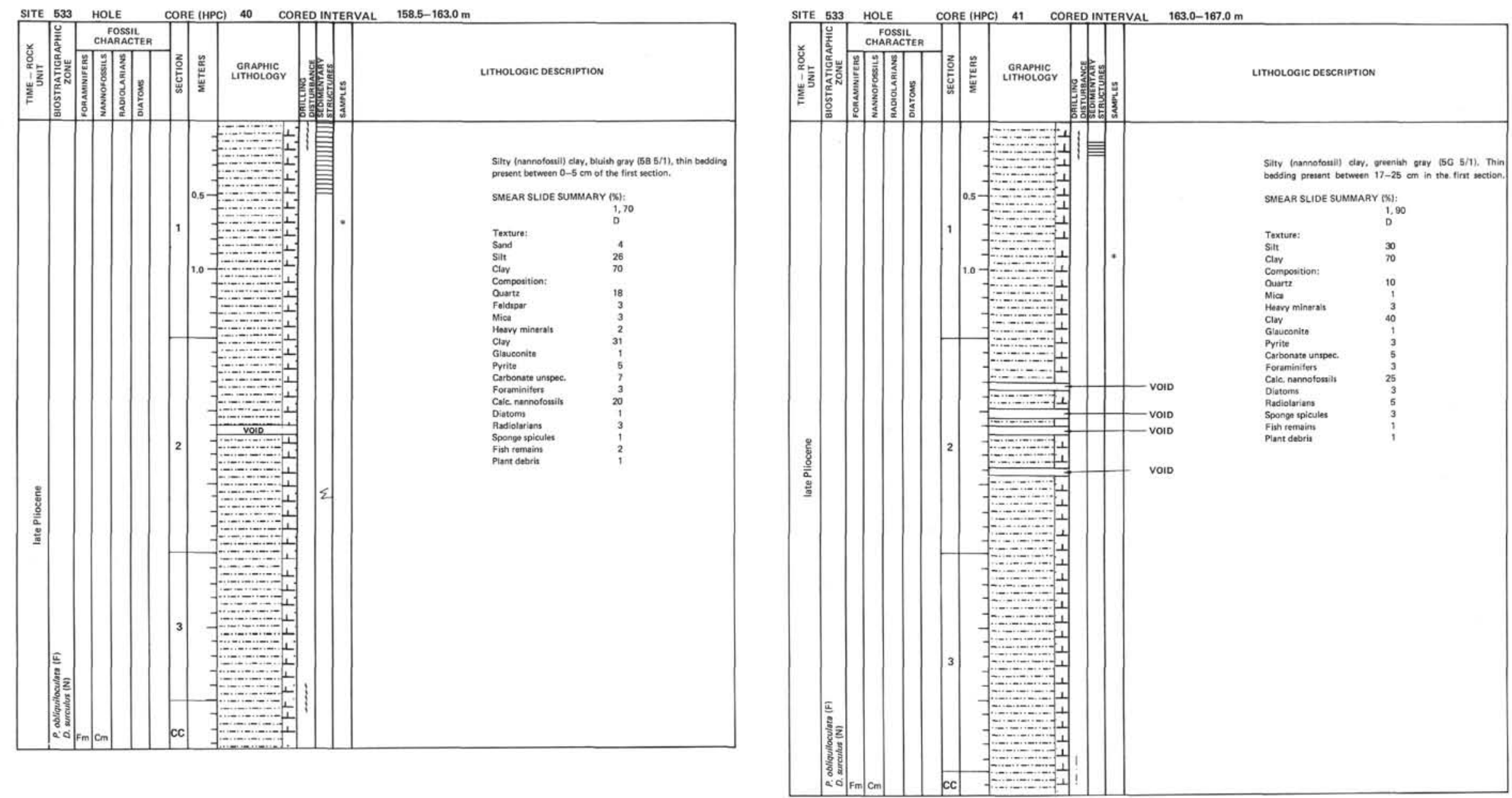

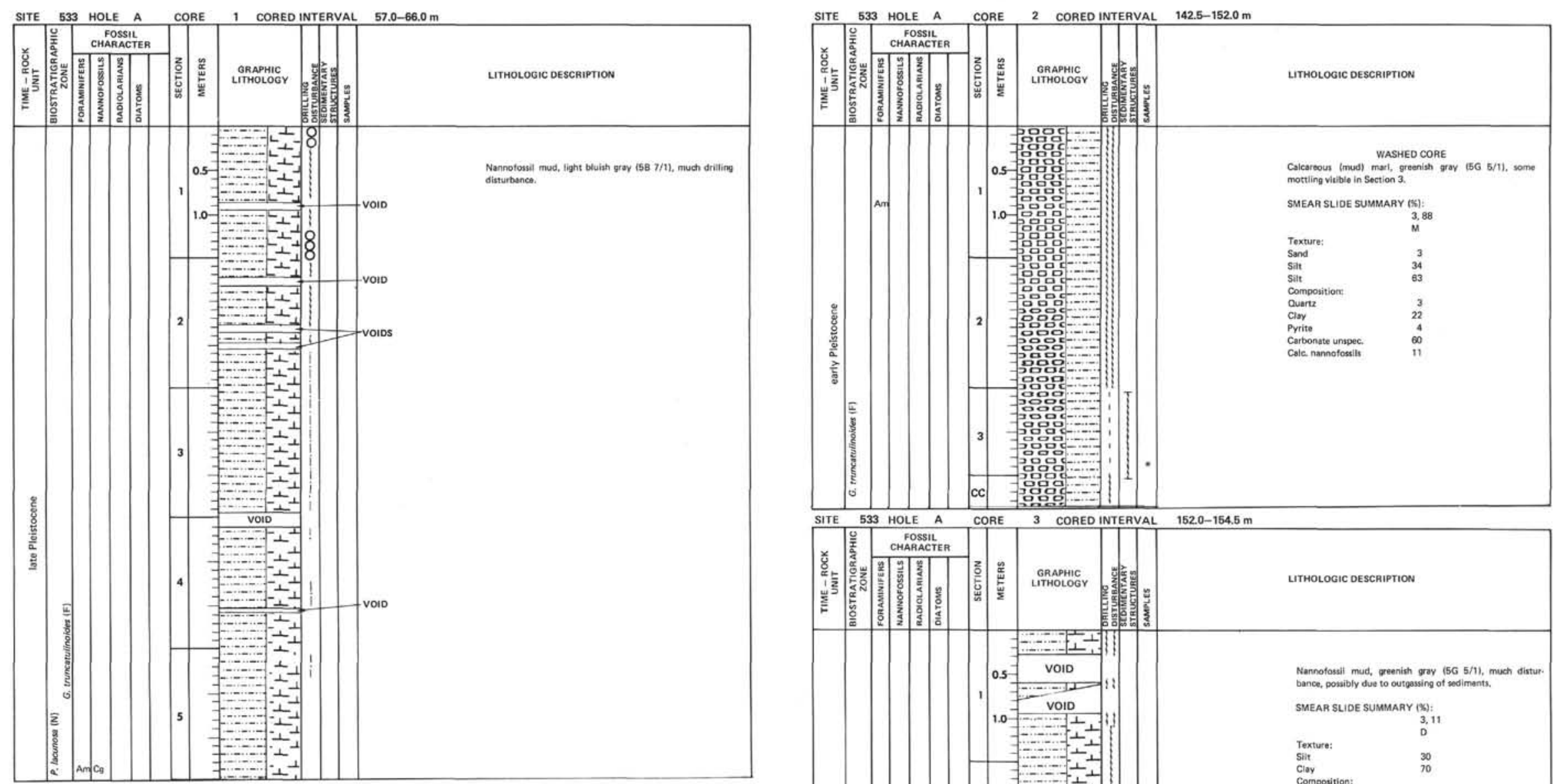

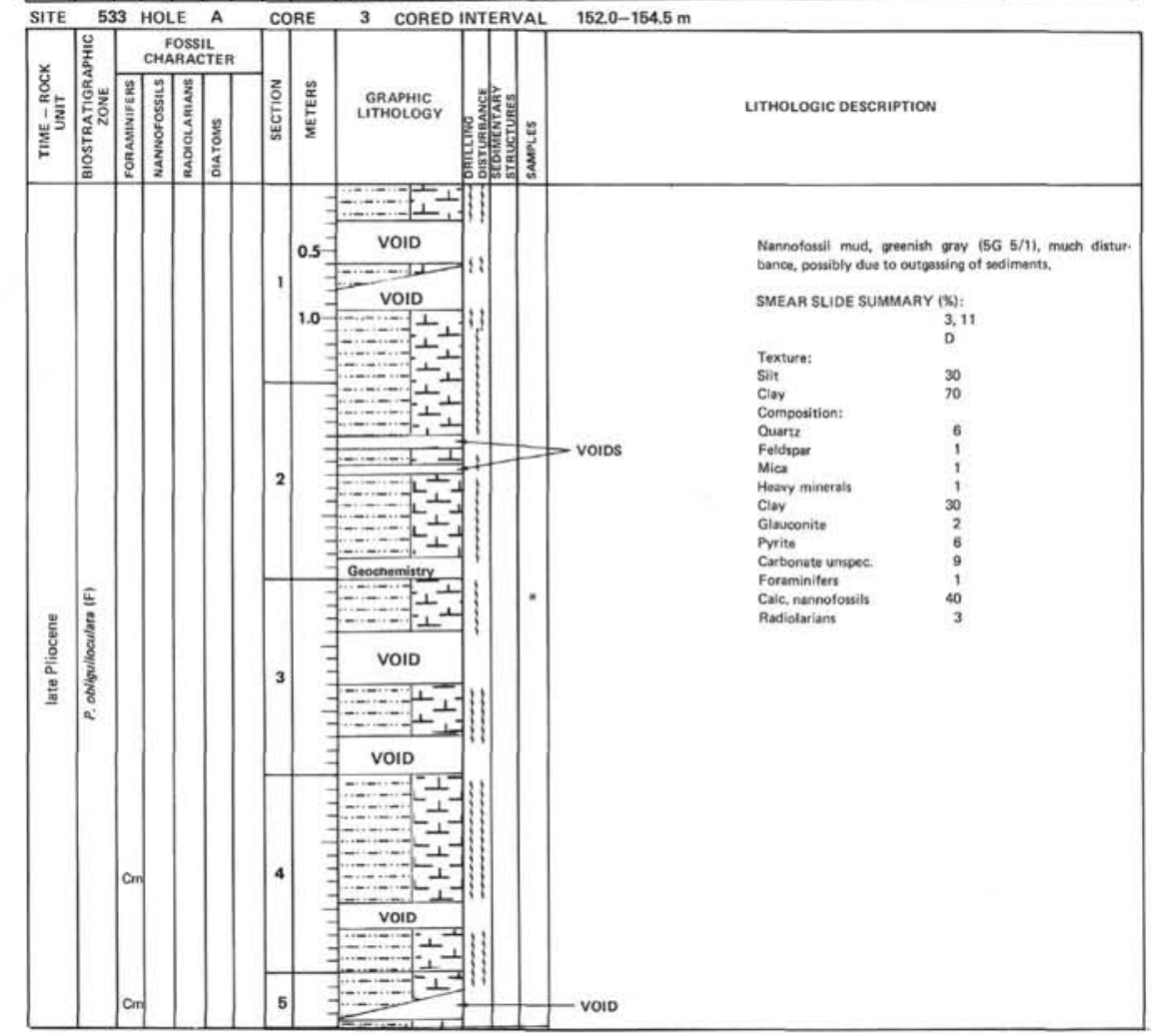




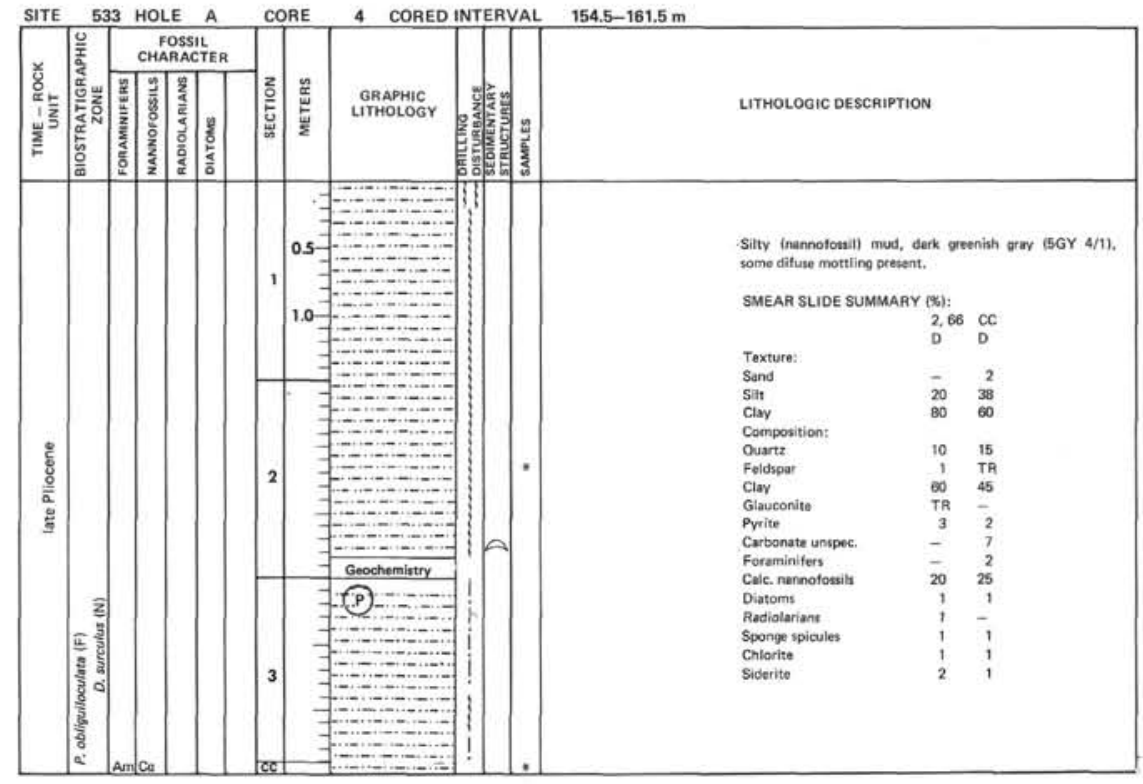

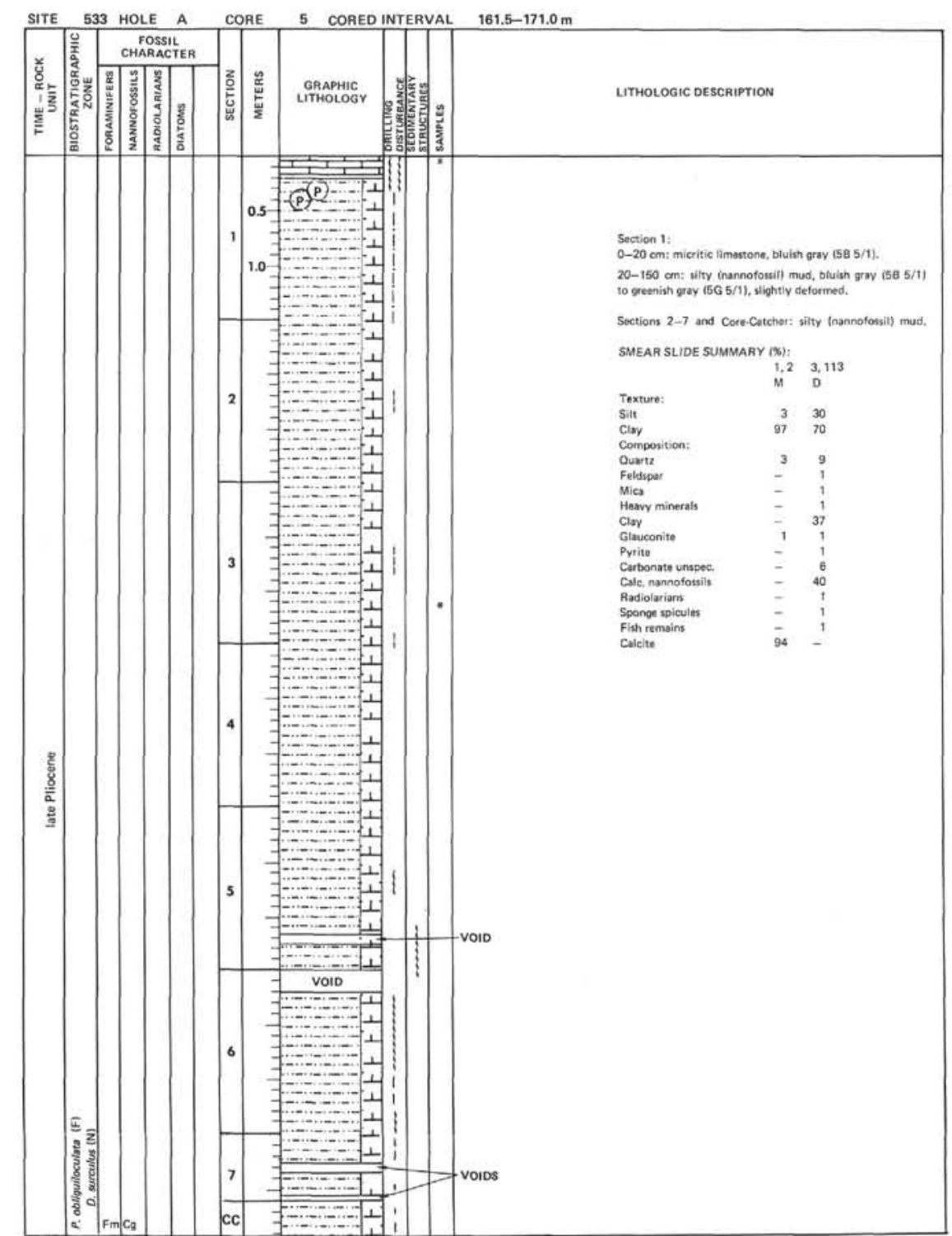



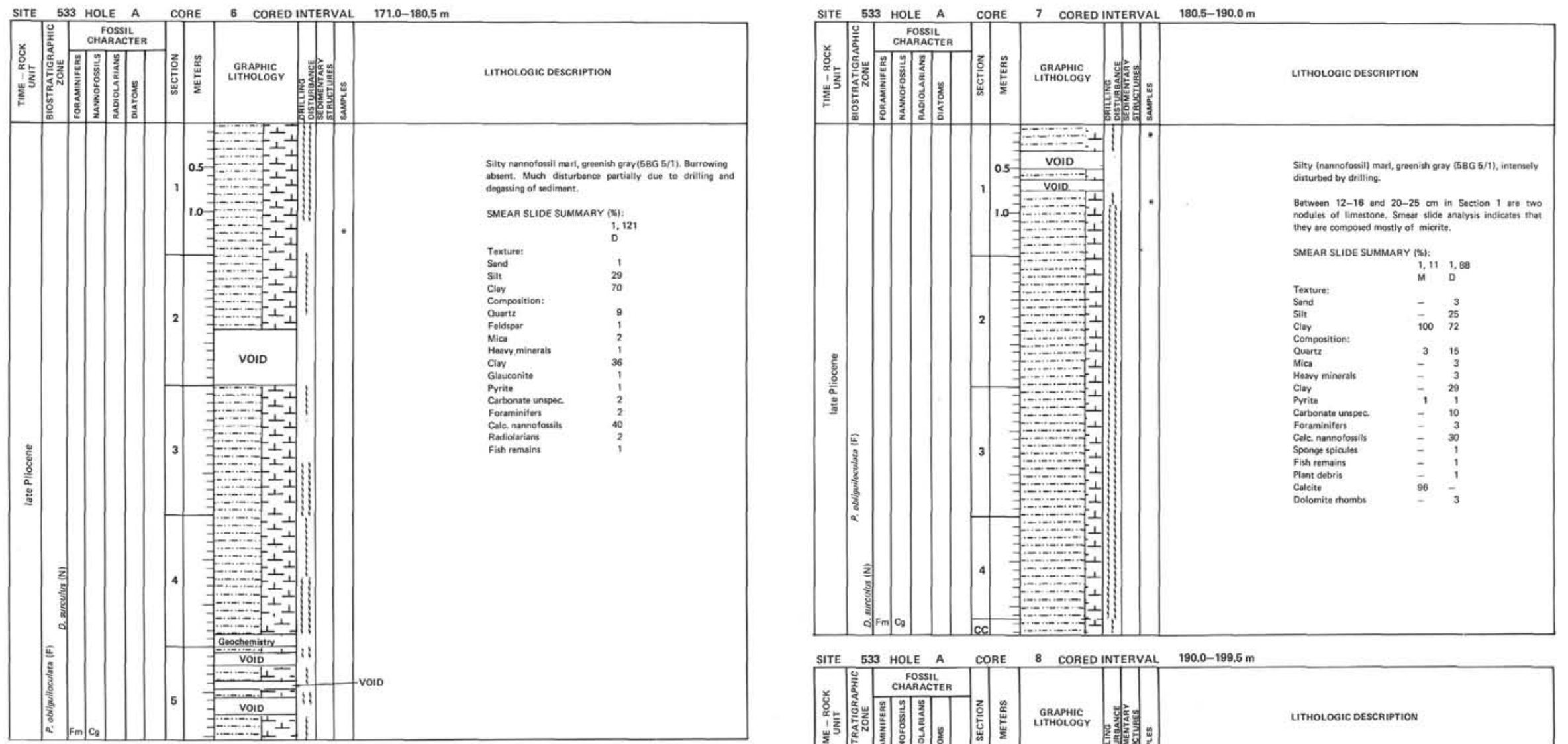

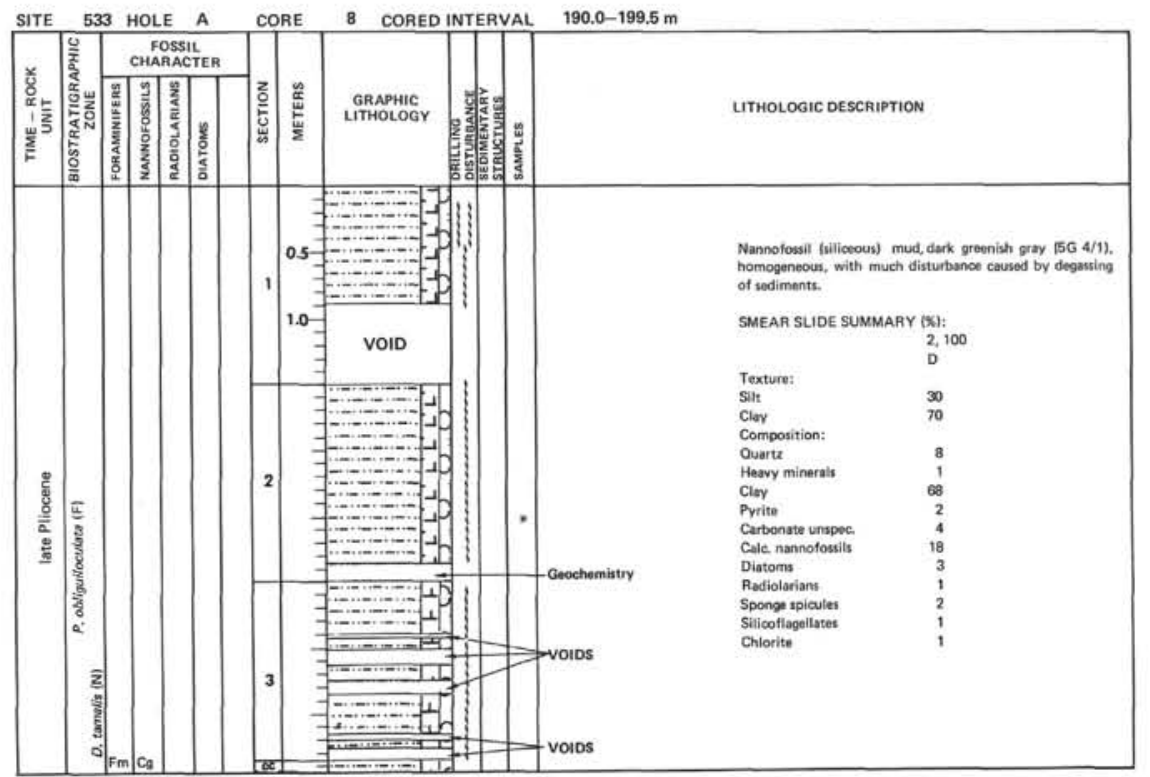



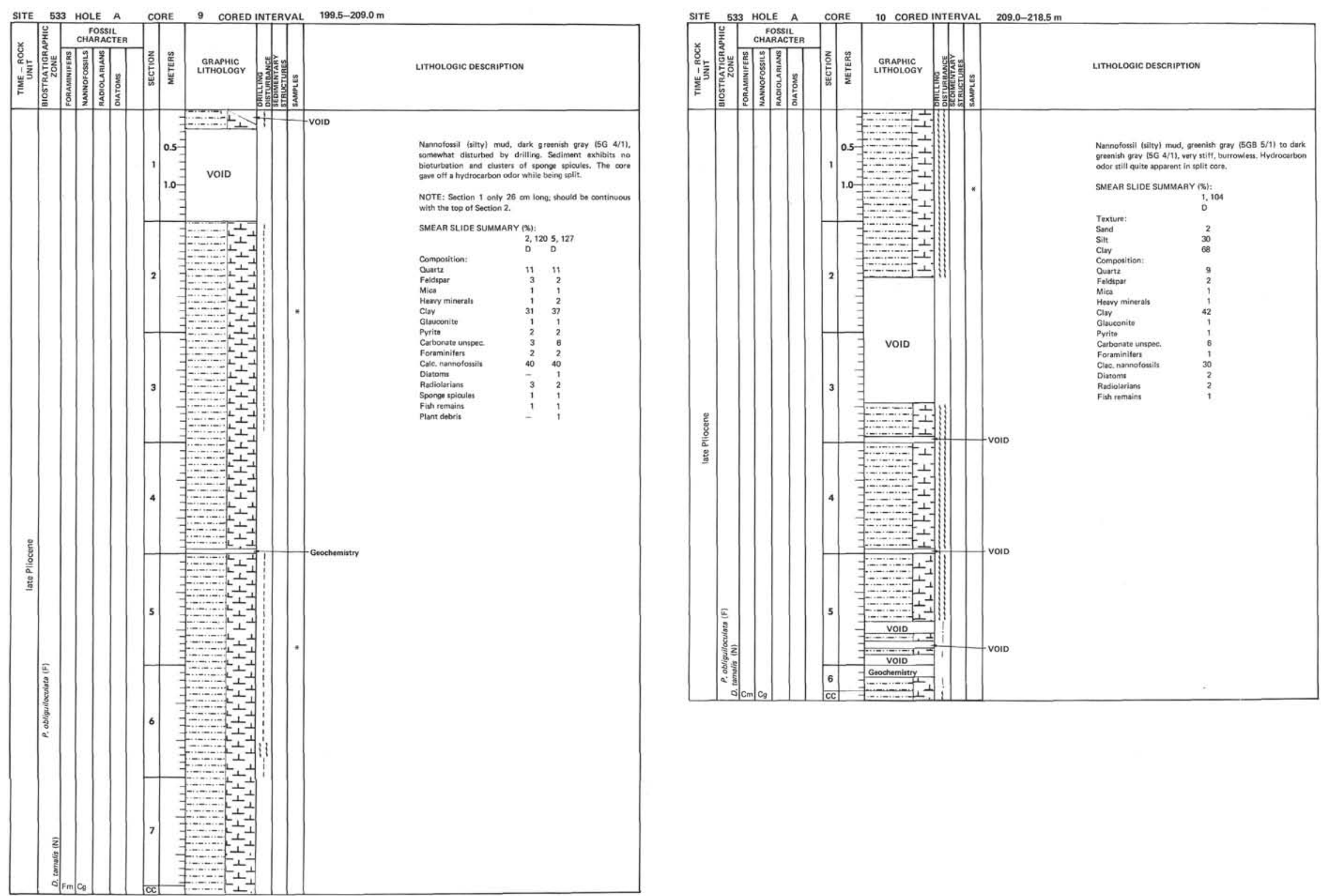

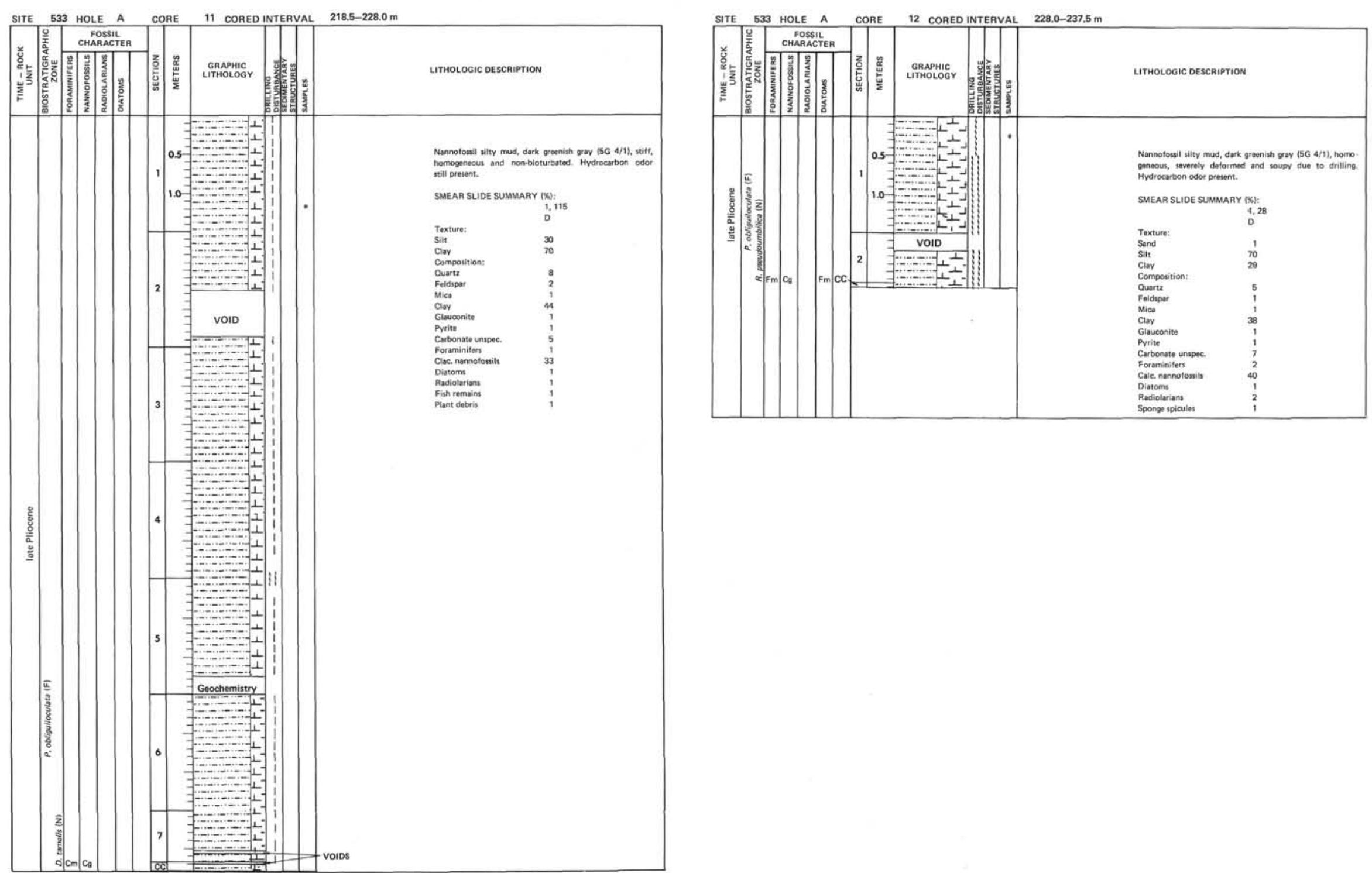


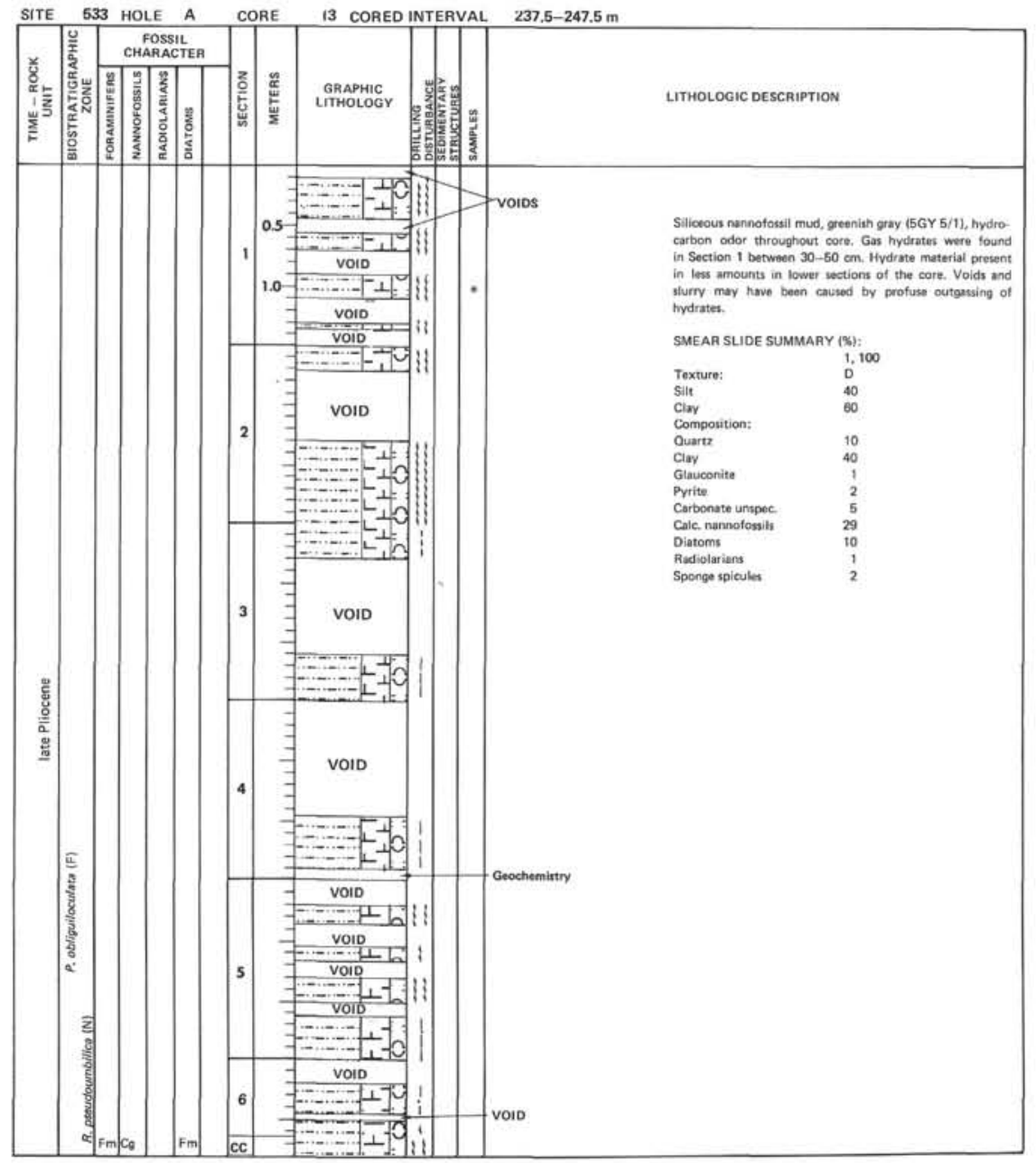

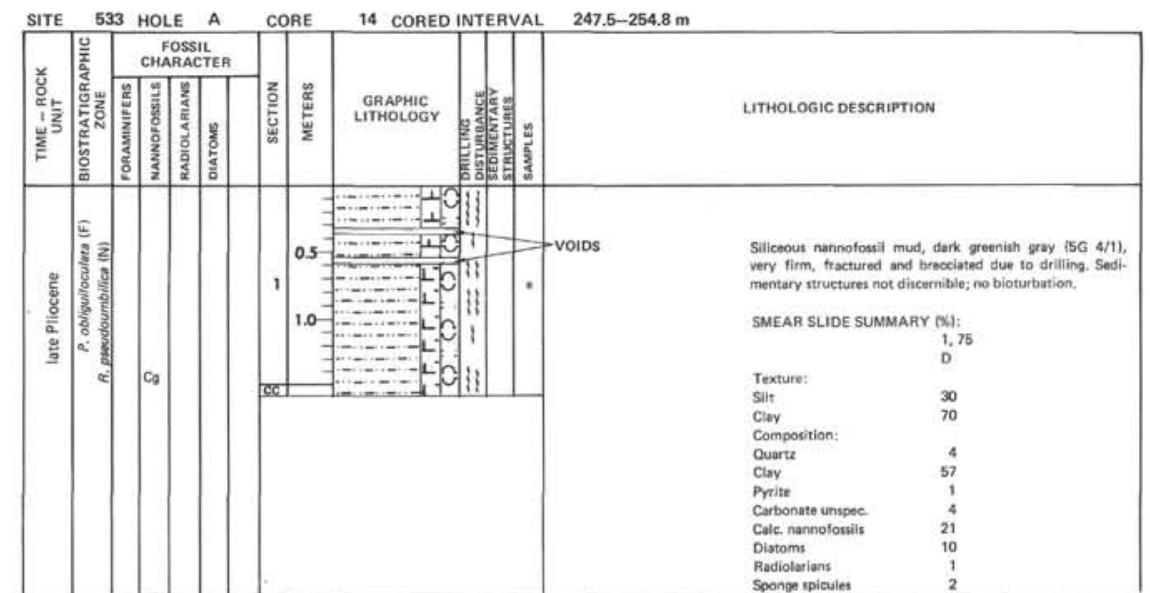

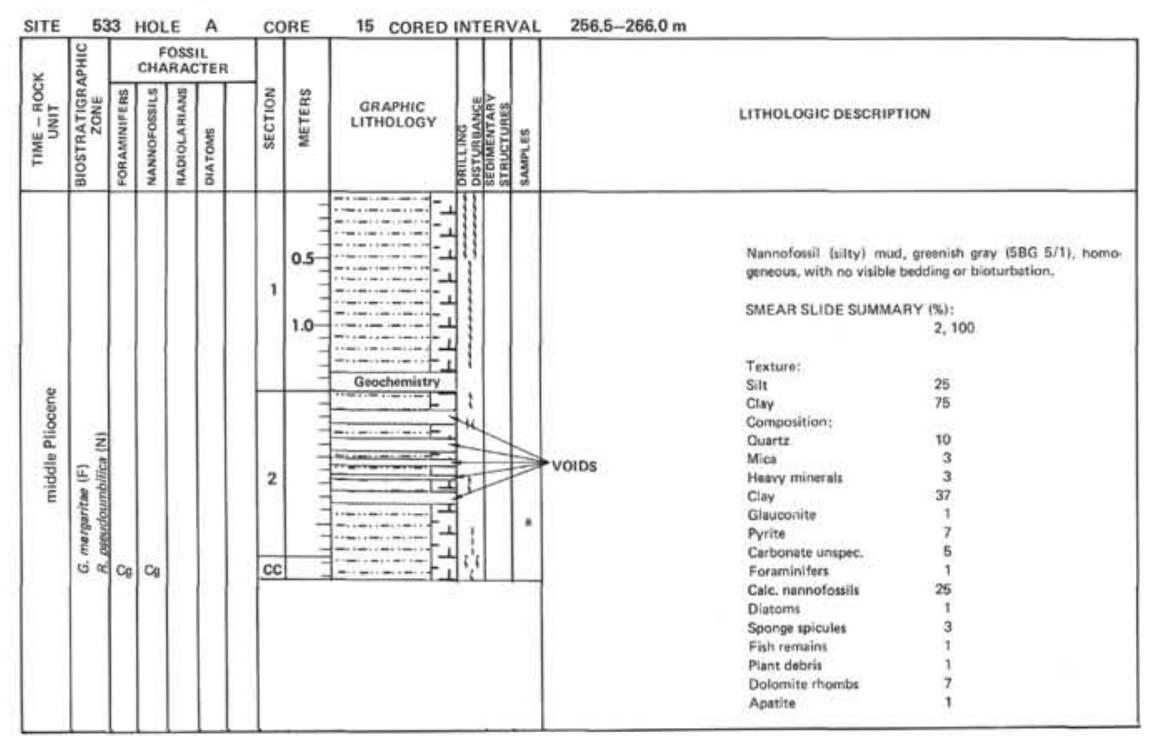


ธू

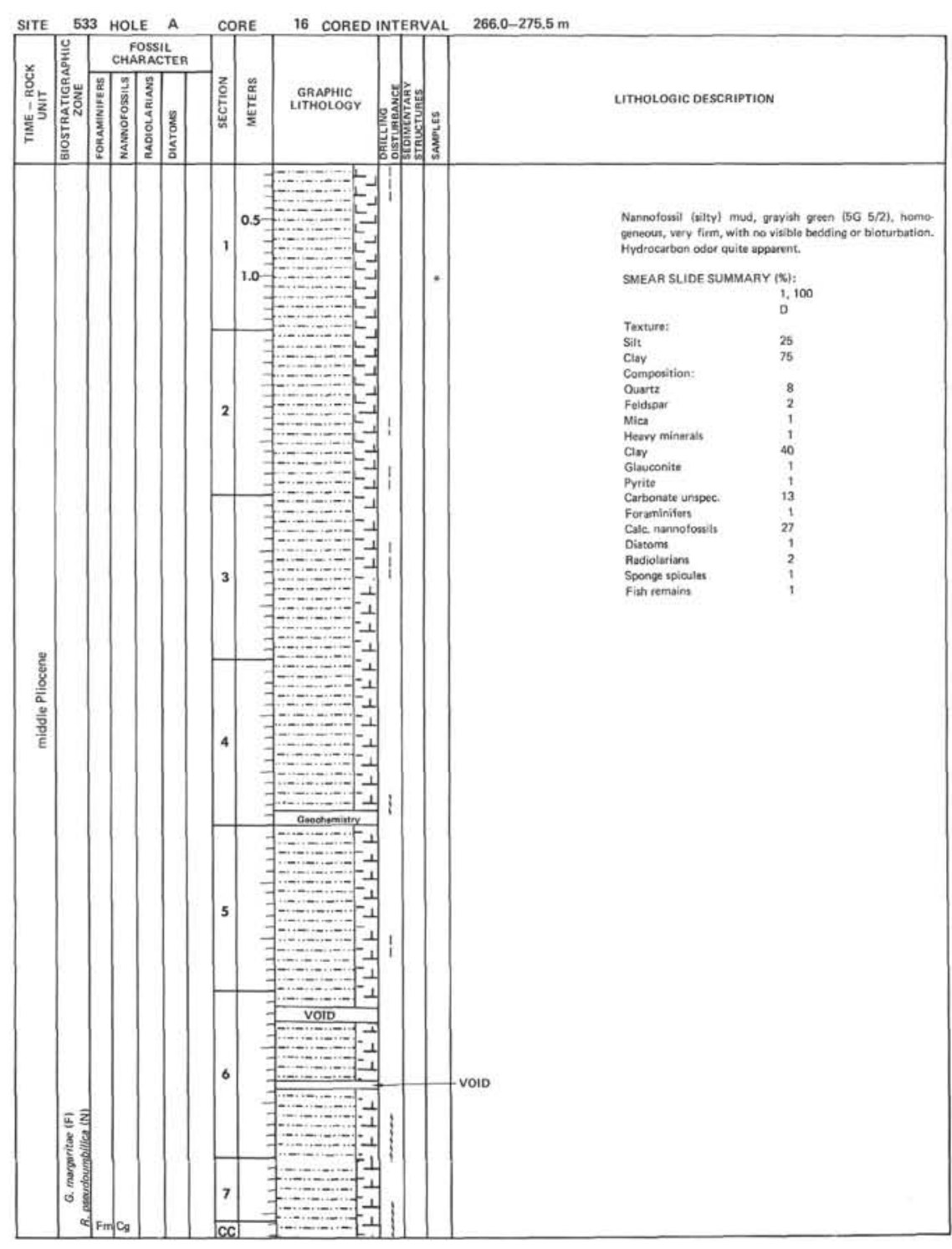

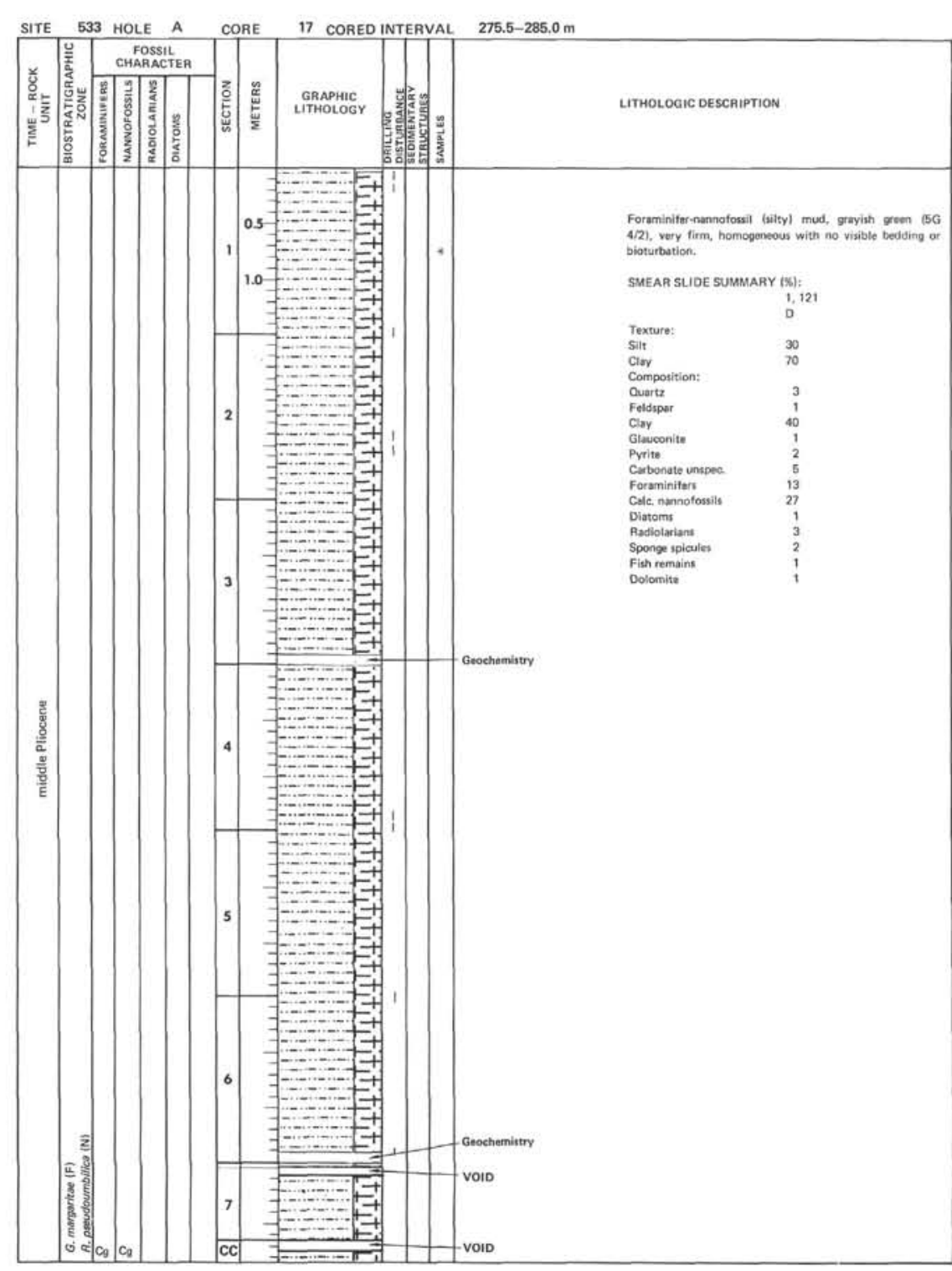



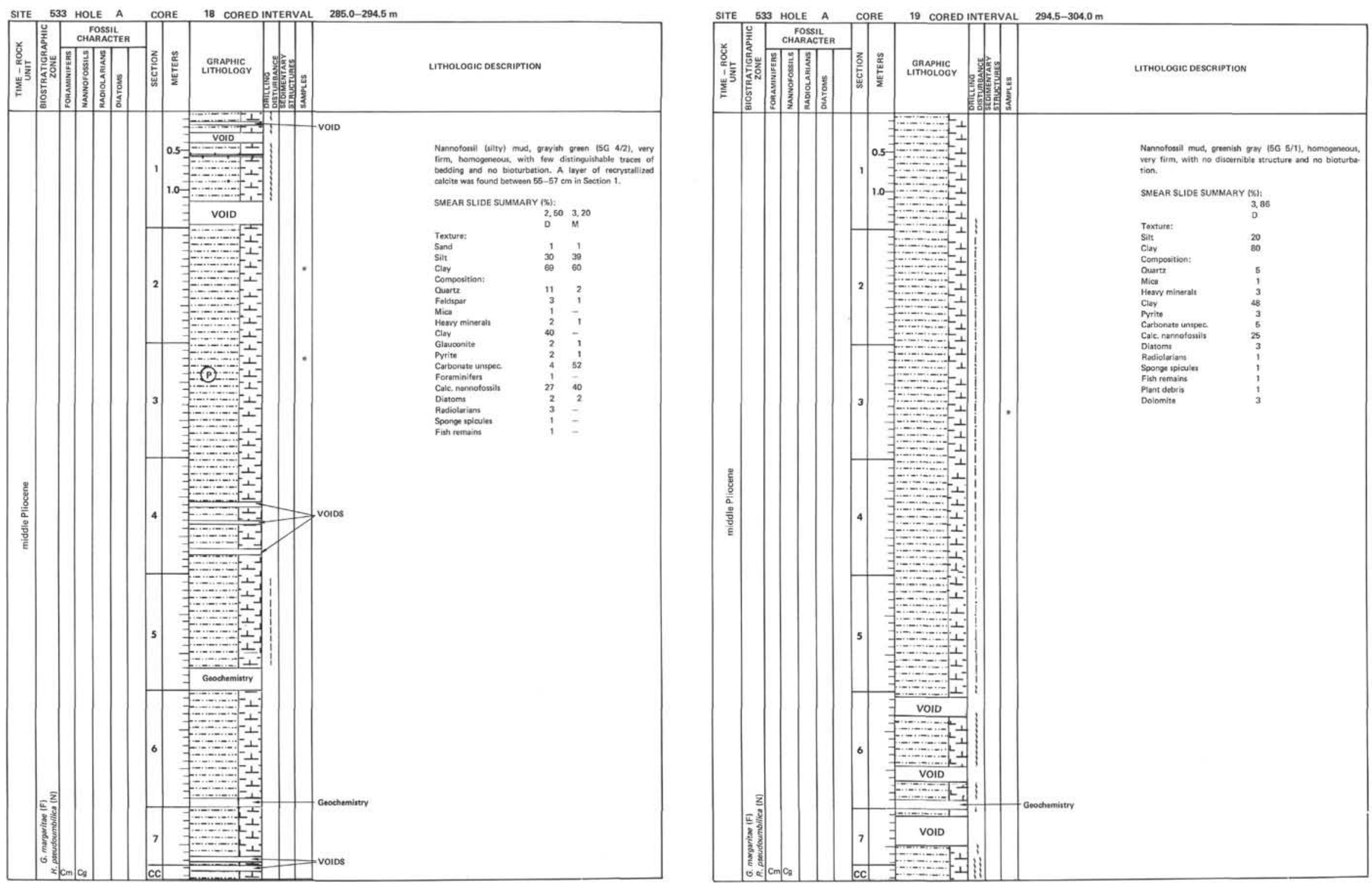

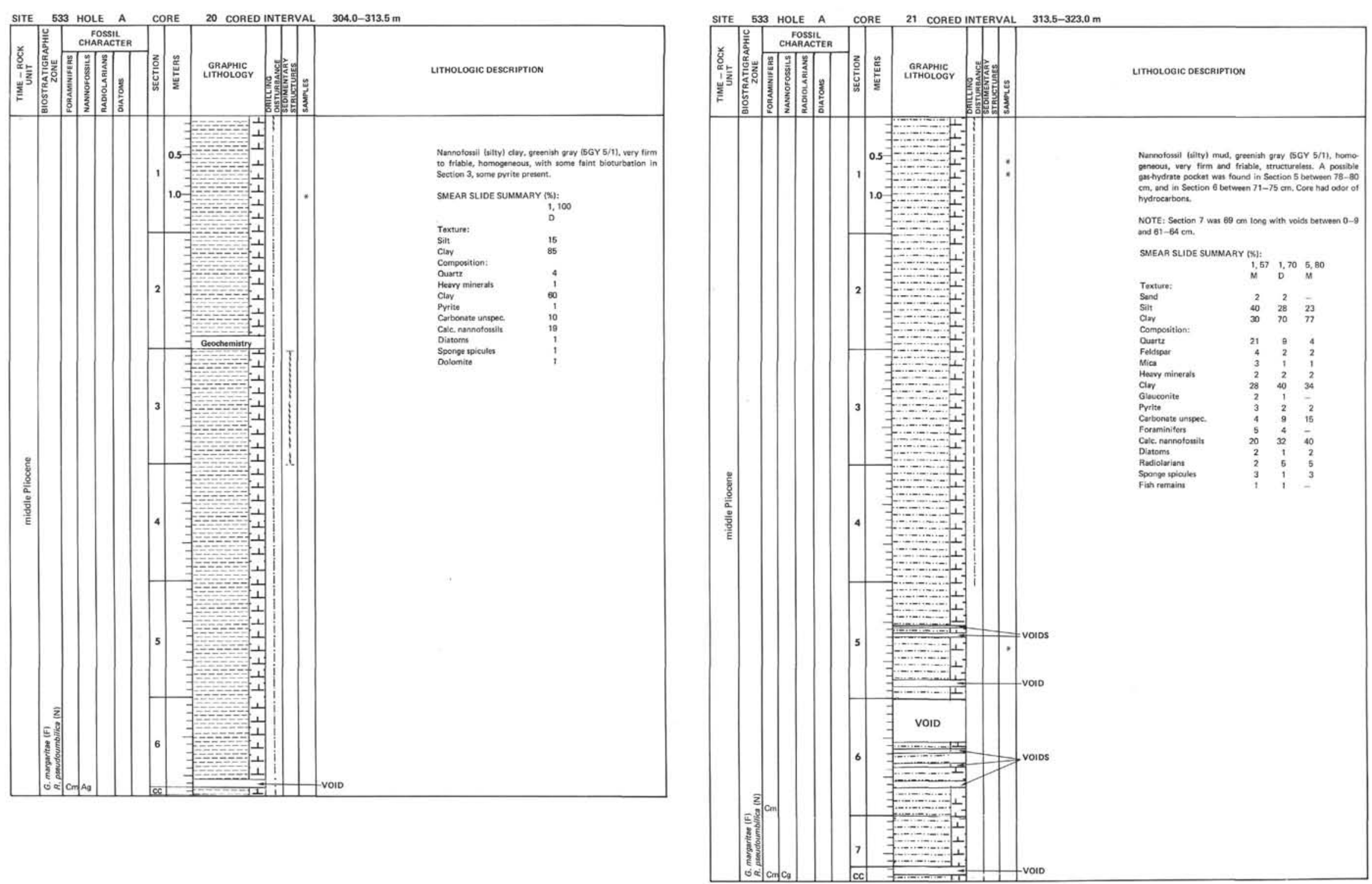

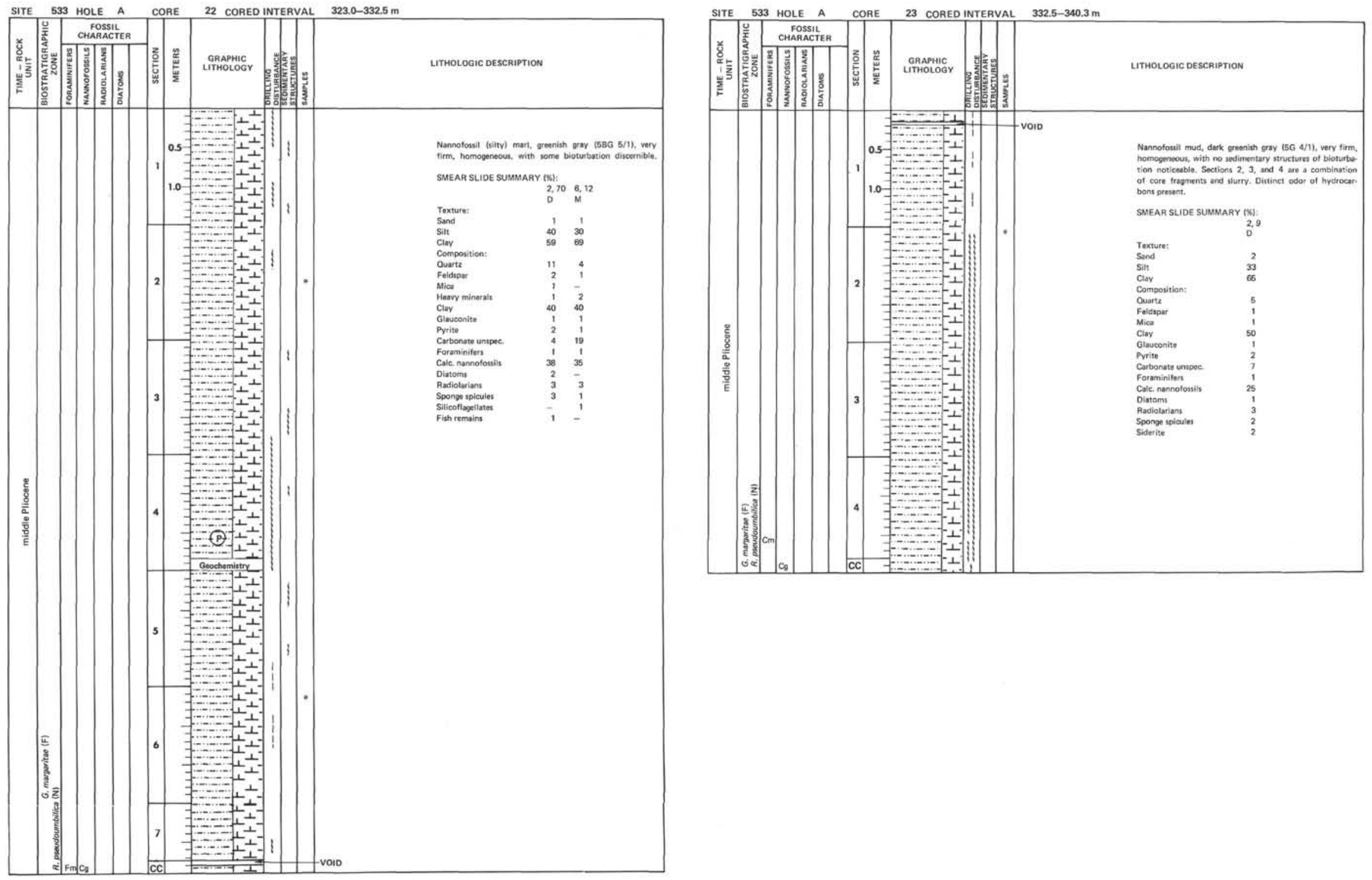


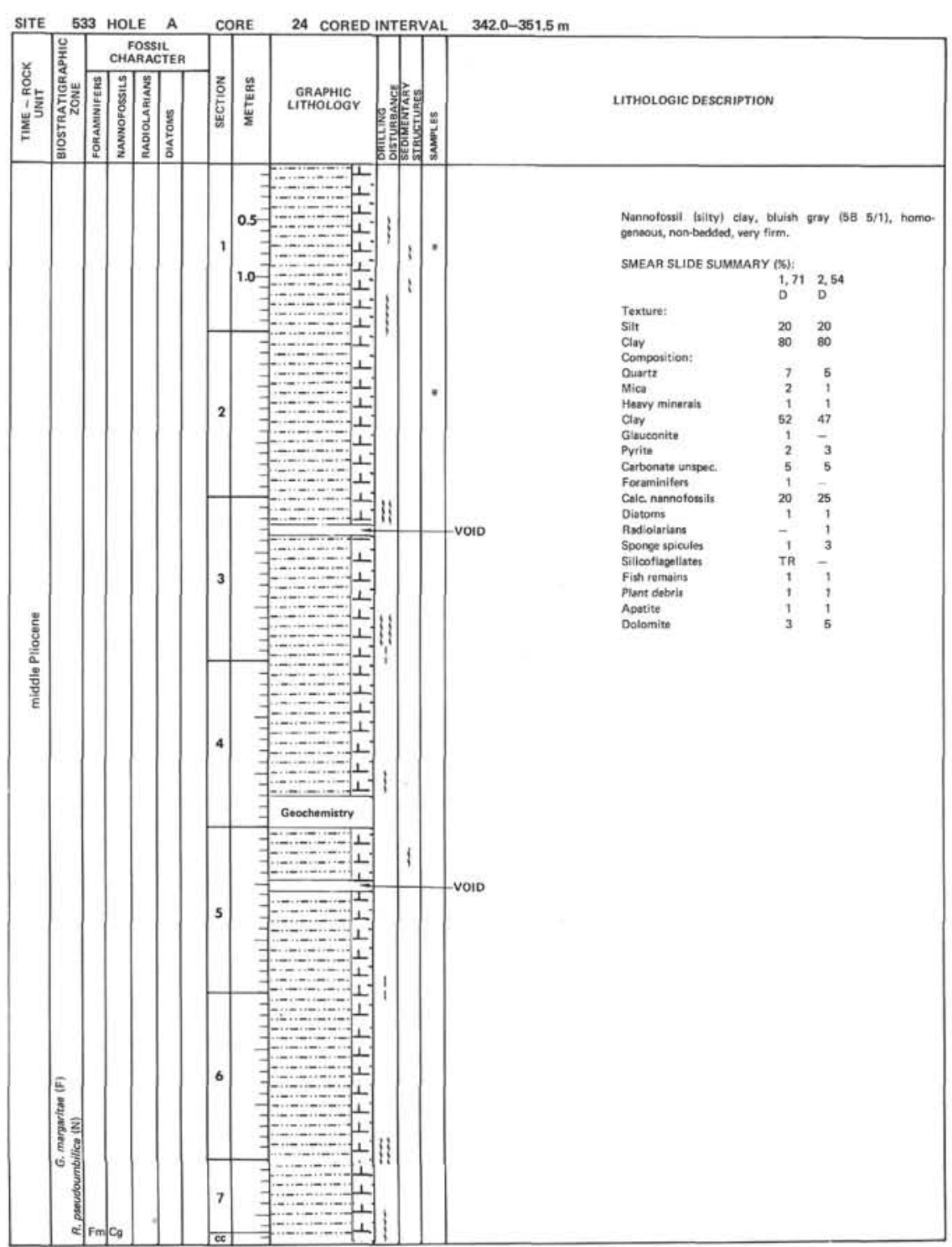

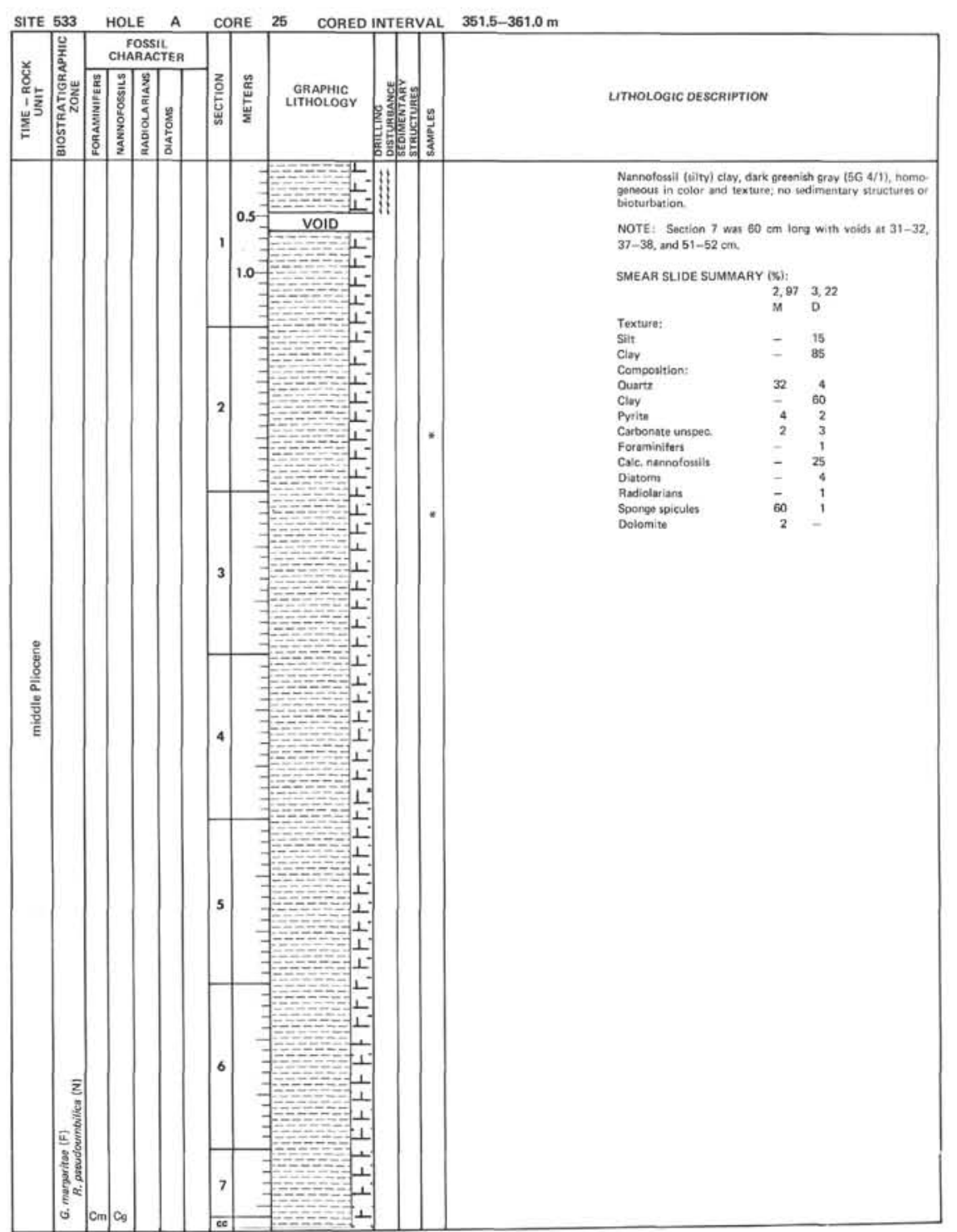



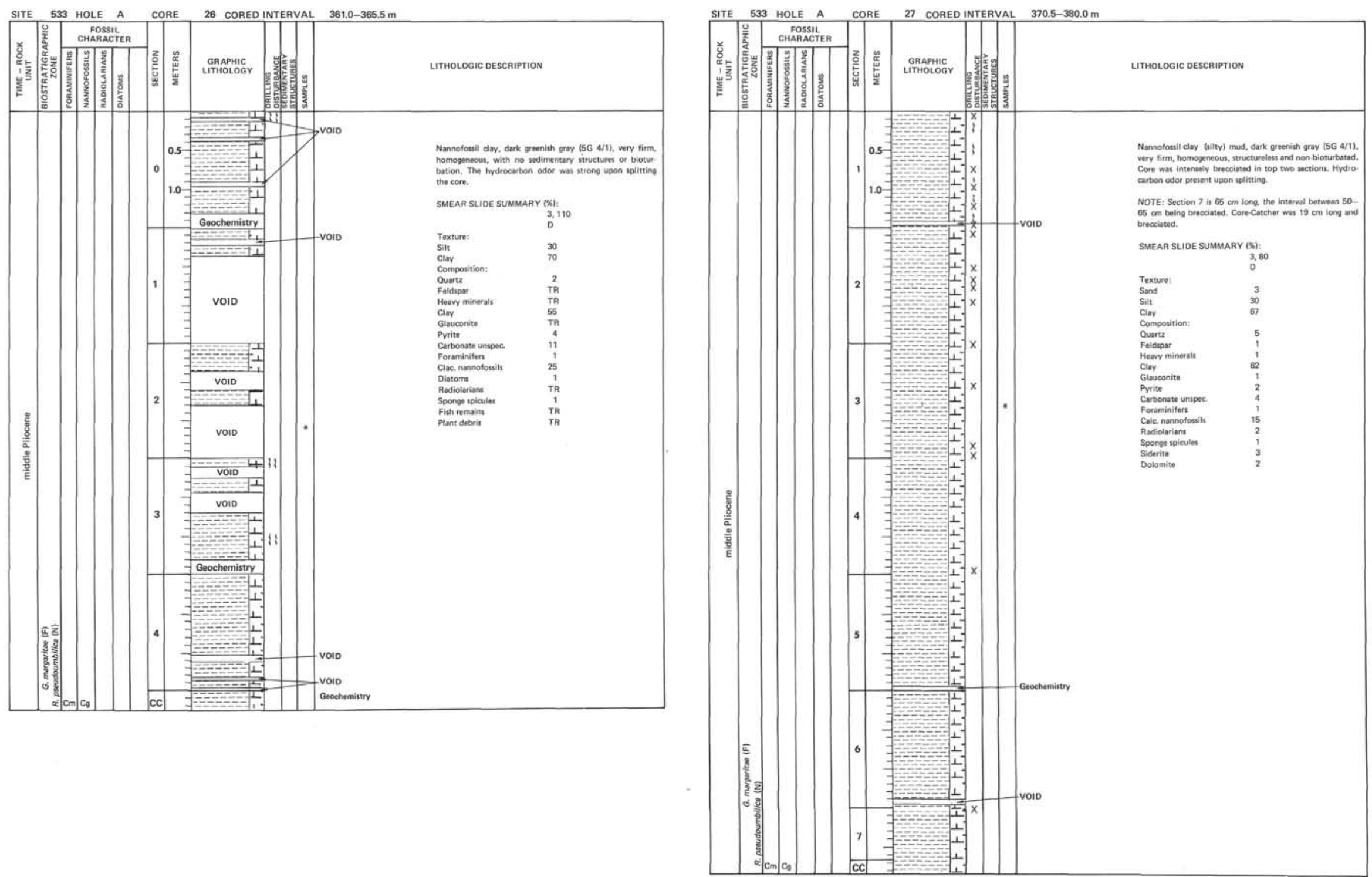

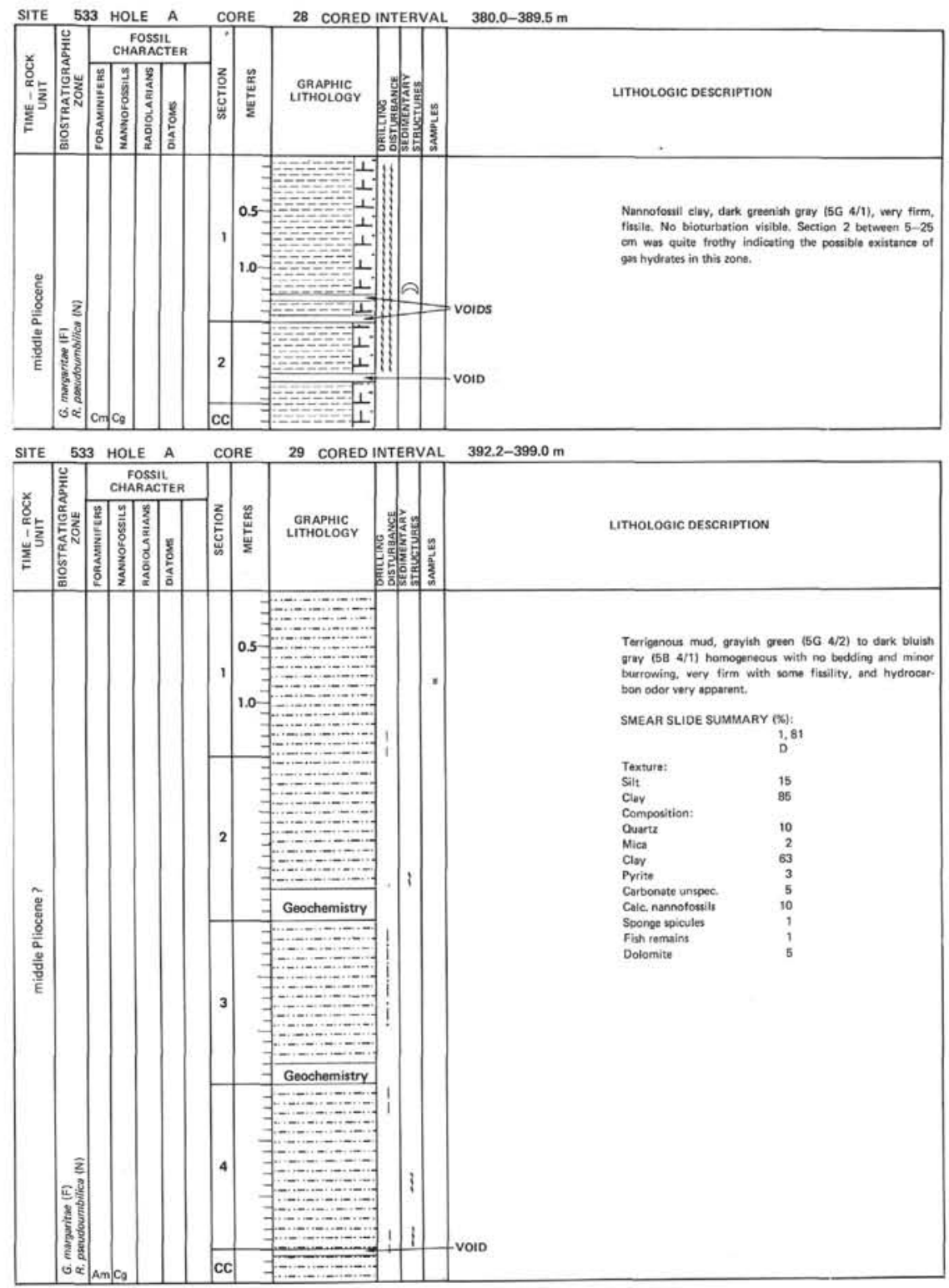


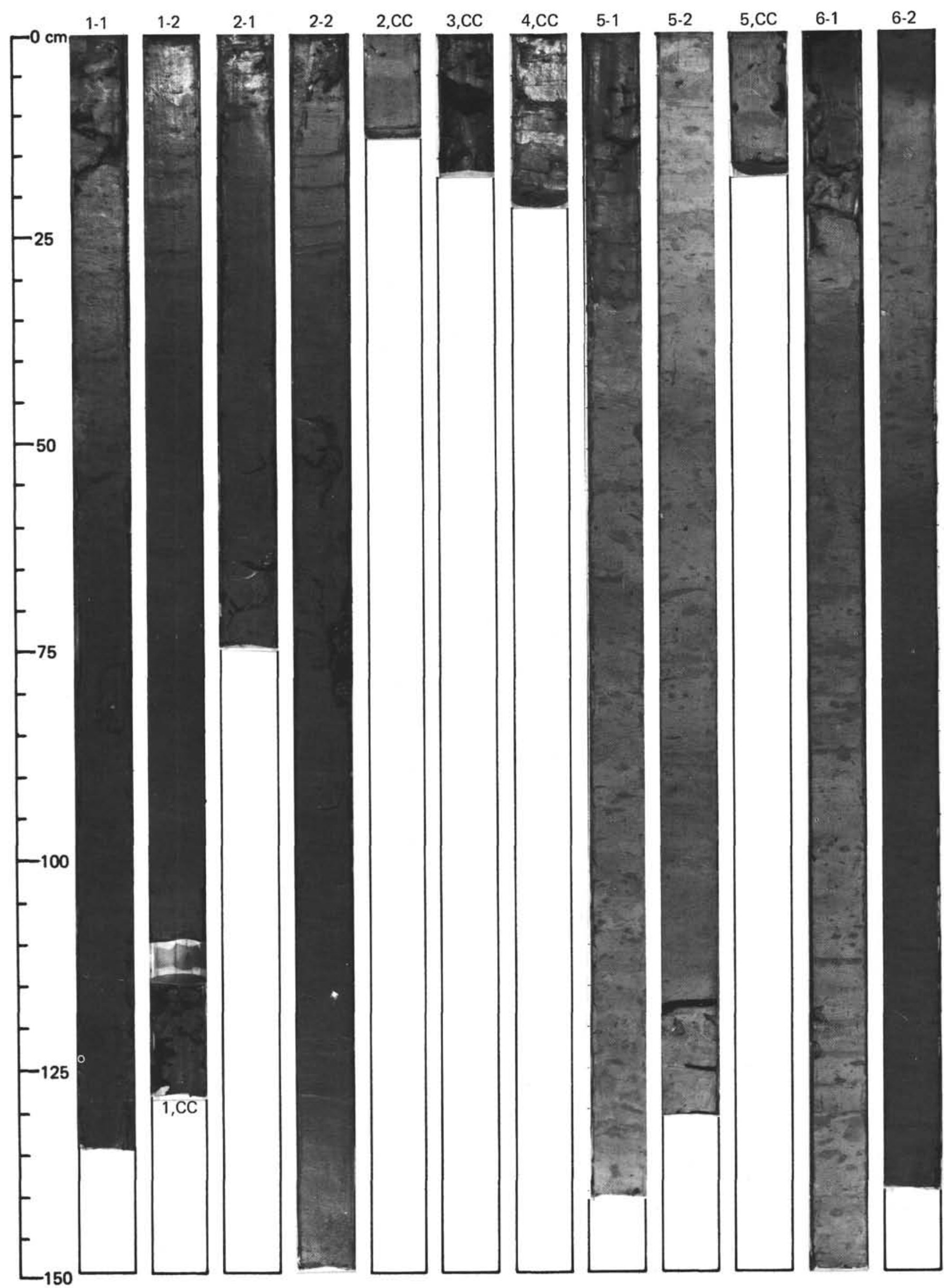


SITE 533 (HOLE 533)

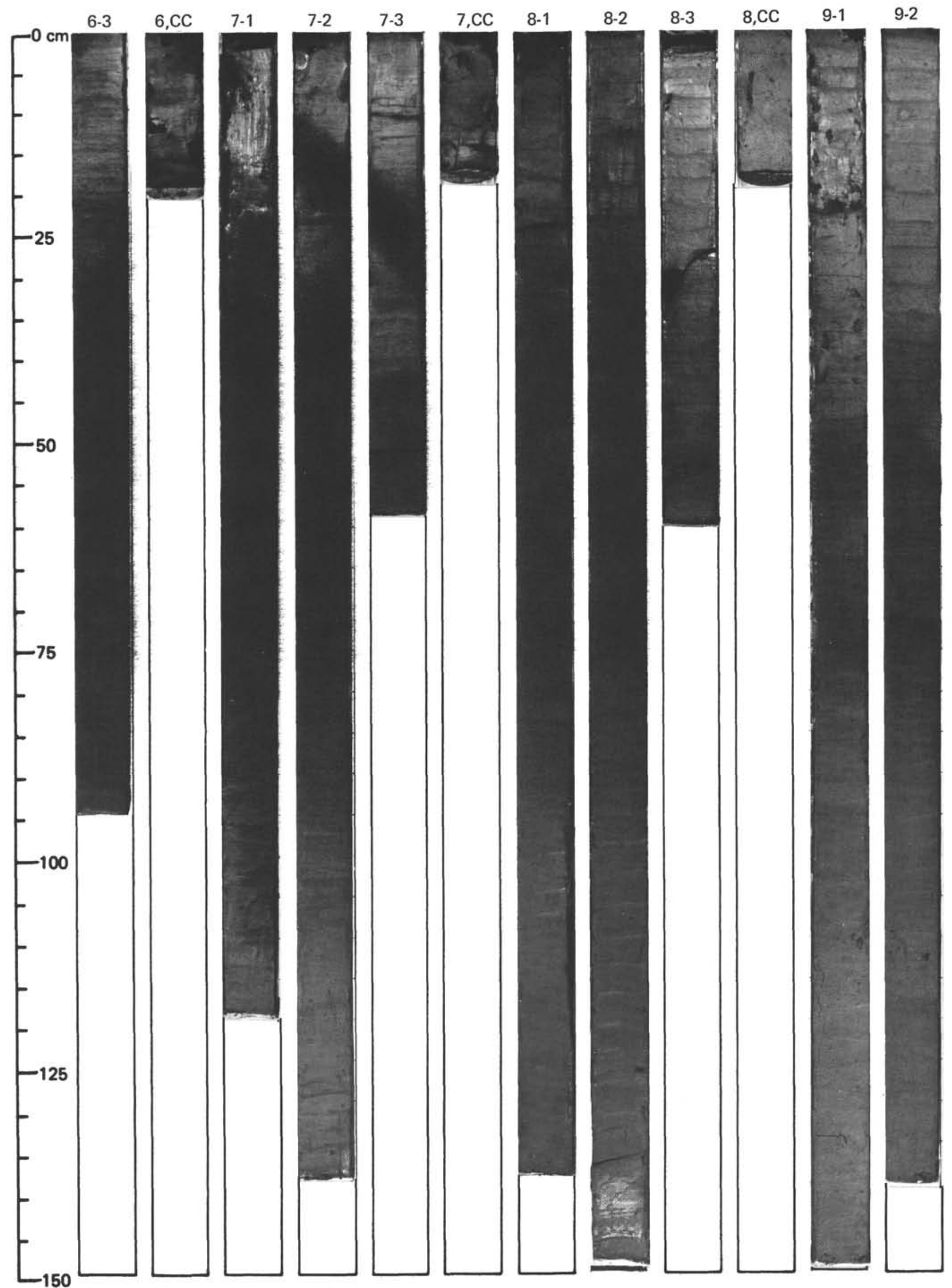


SITE 533 (HOLE 533)

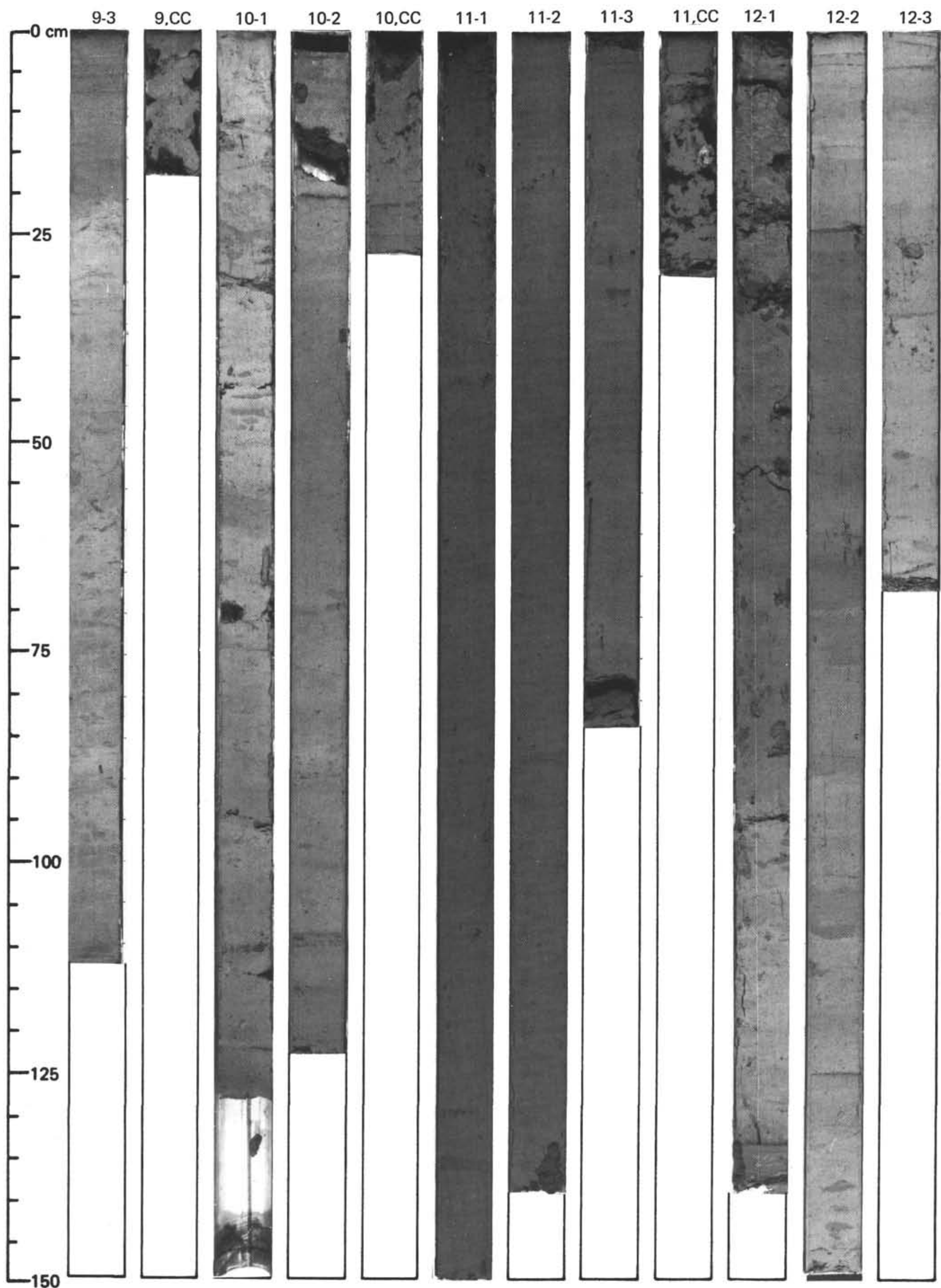


SITE 533 (HOLE 533)

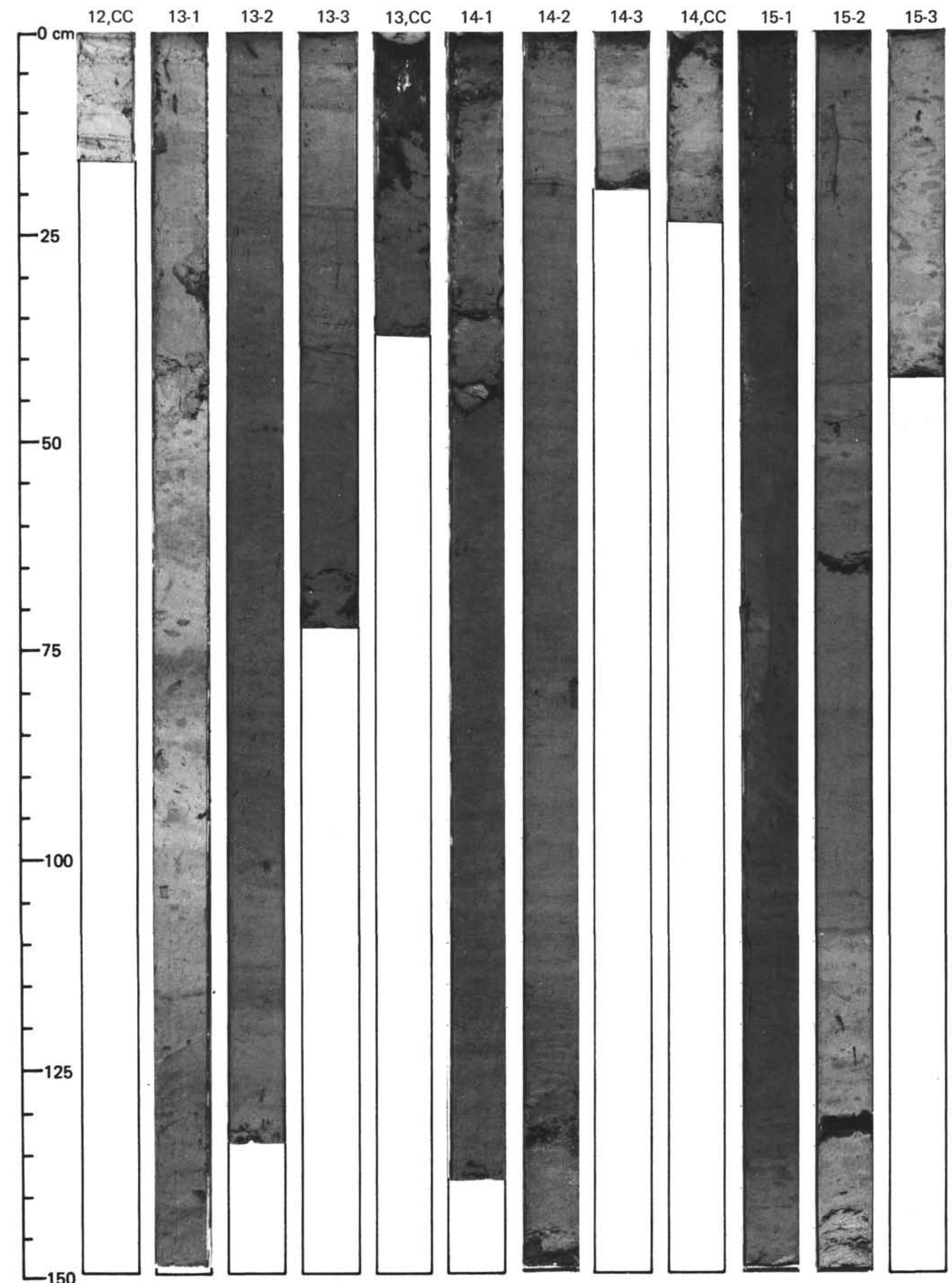


SITE 533 (HOLE 533)

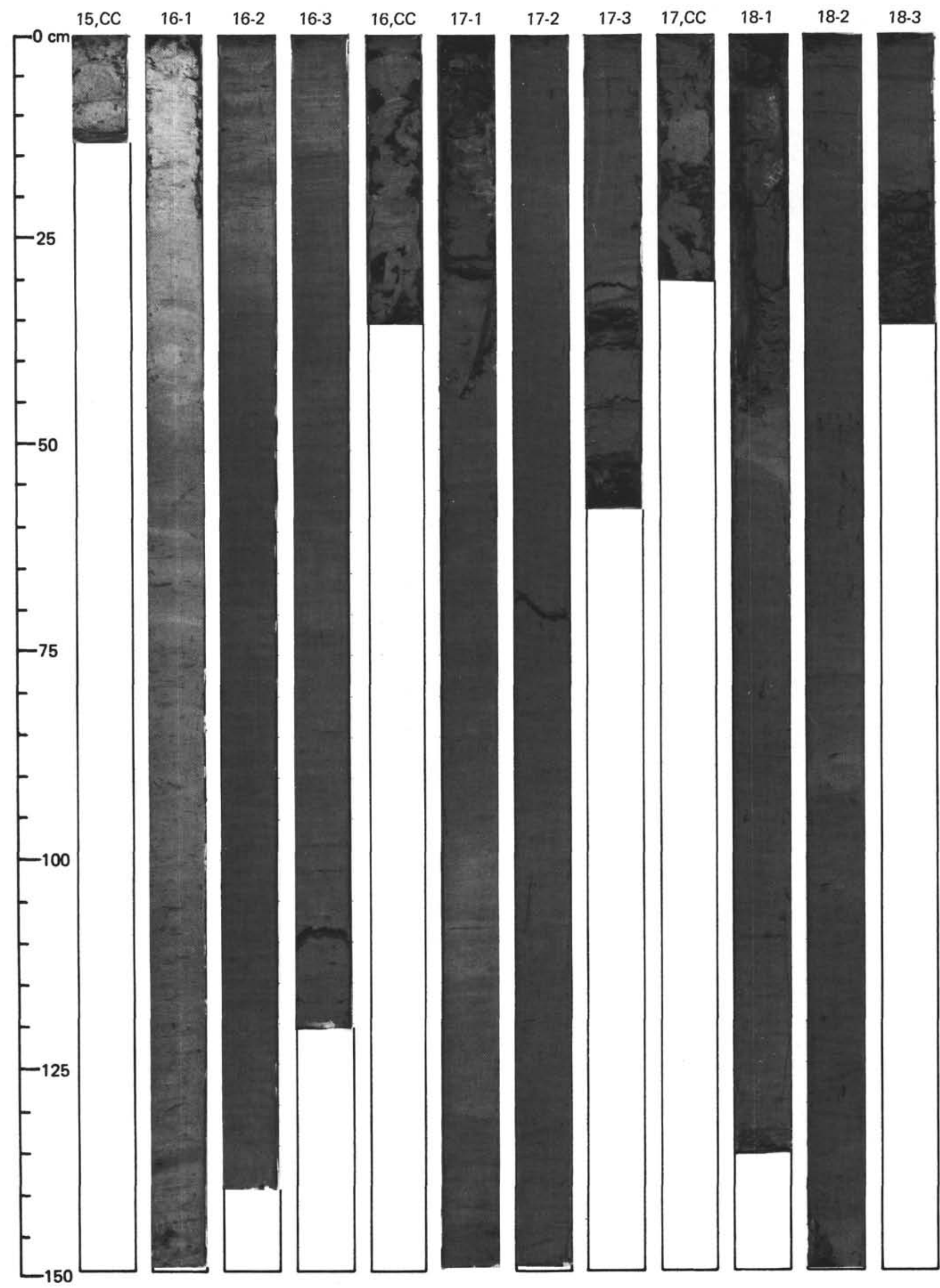


SITE 533 (HOLE 533)

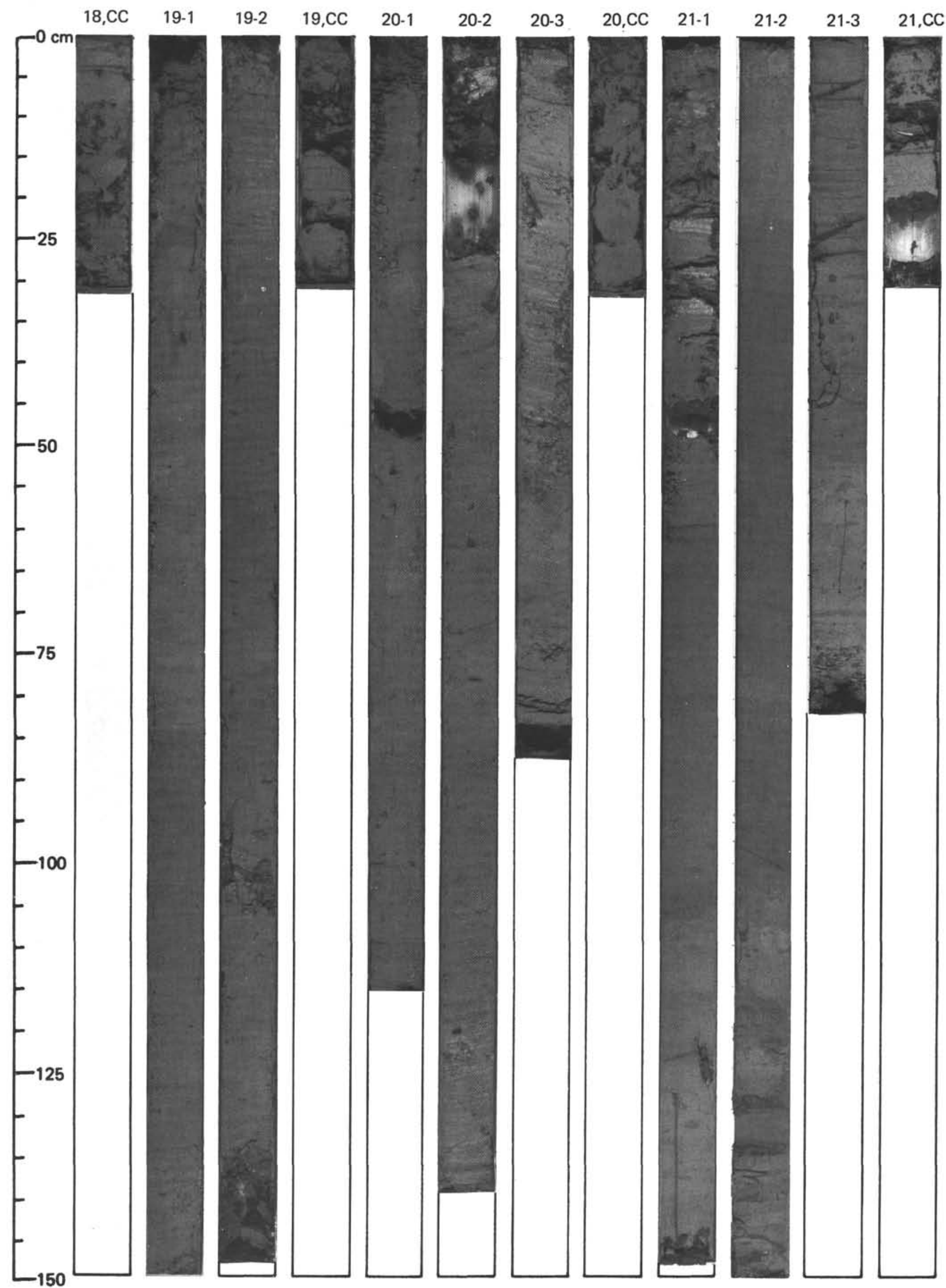


SITE 533 (HOLE 533)

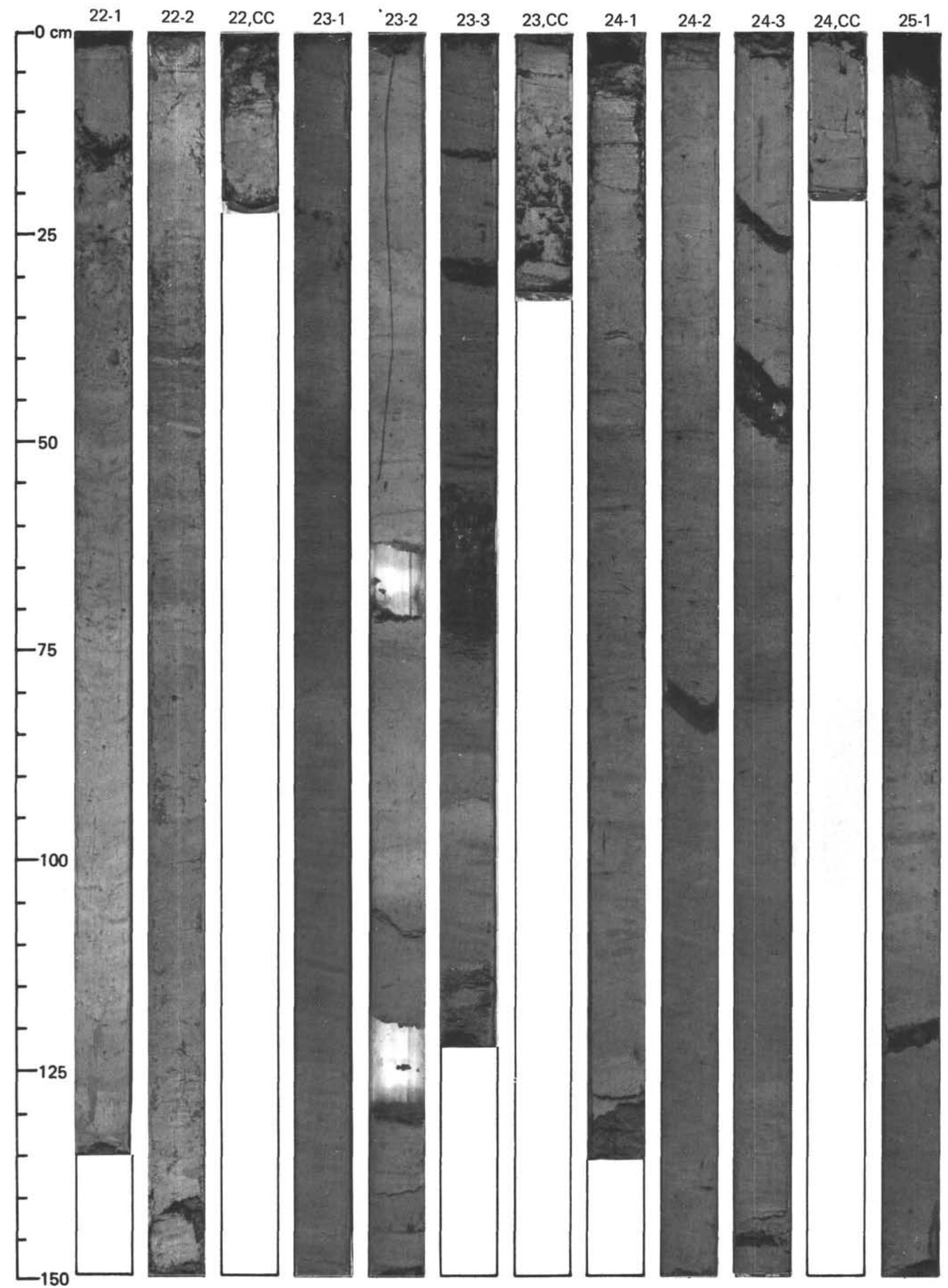


SITE 533 (HOLE 533)

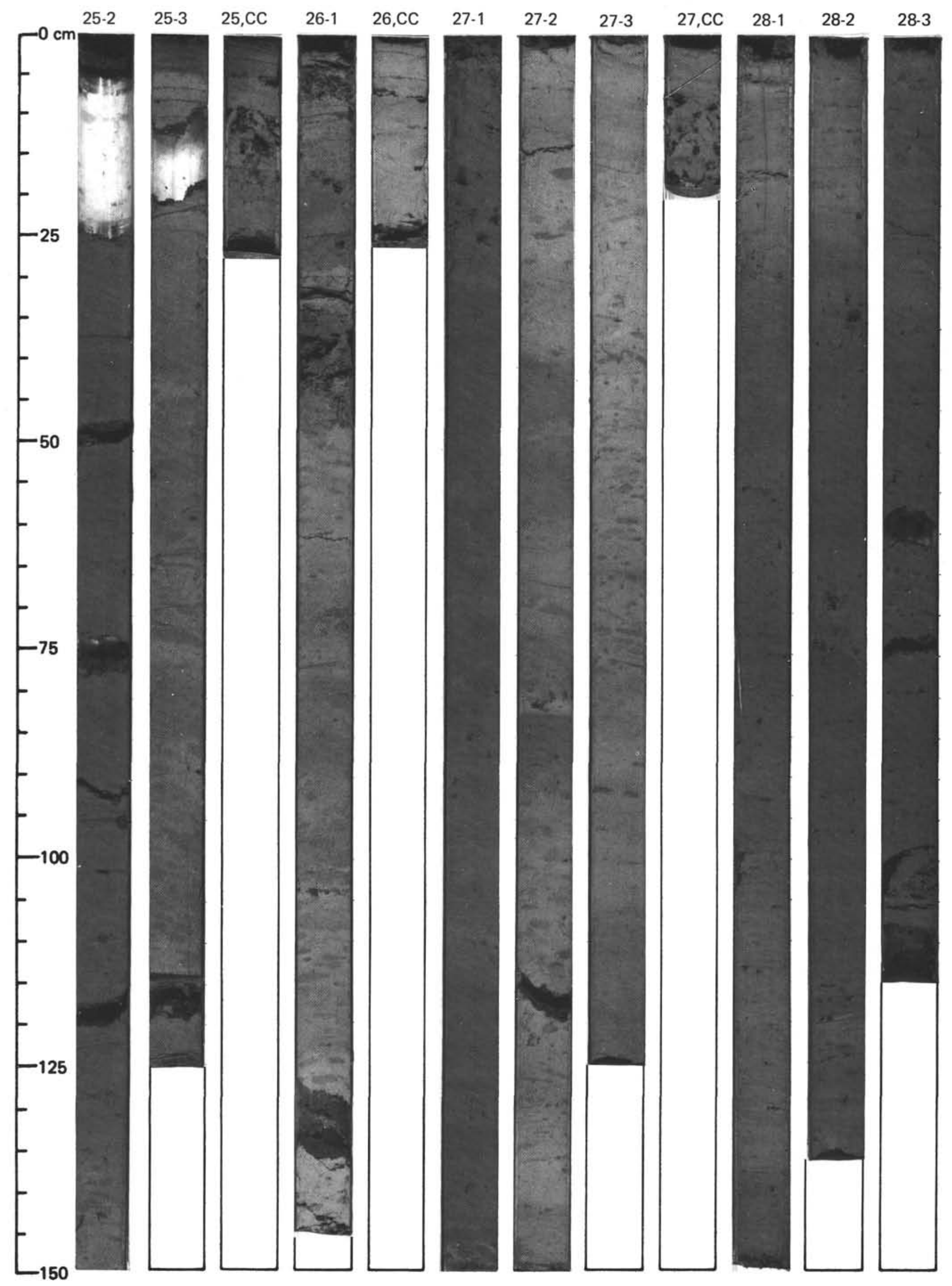


SITE 533 (HOLE 533)

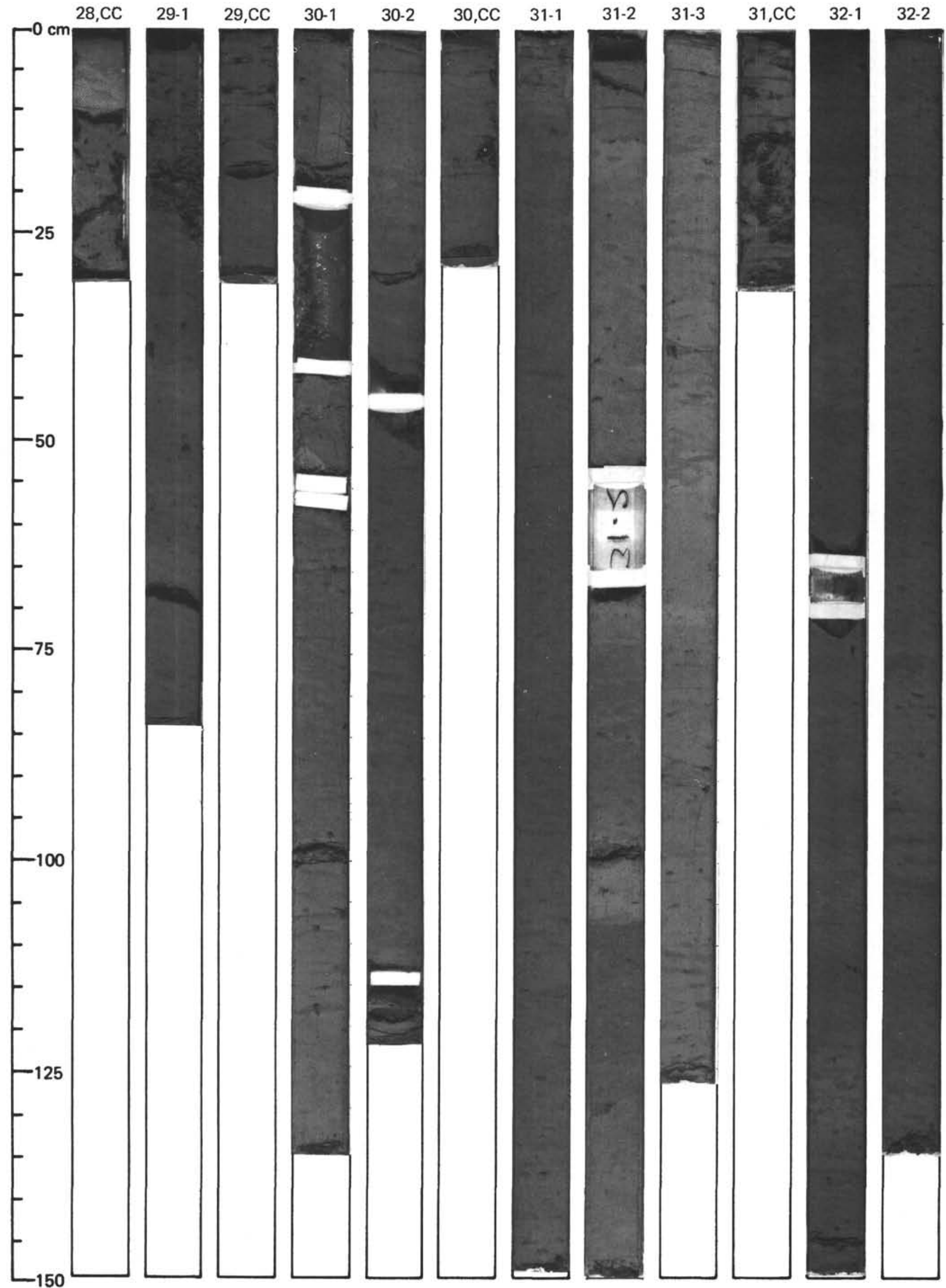


SITE 533 (HOLE 533)

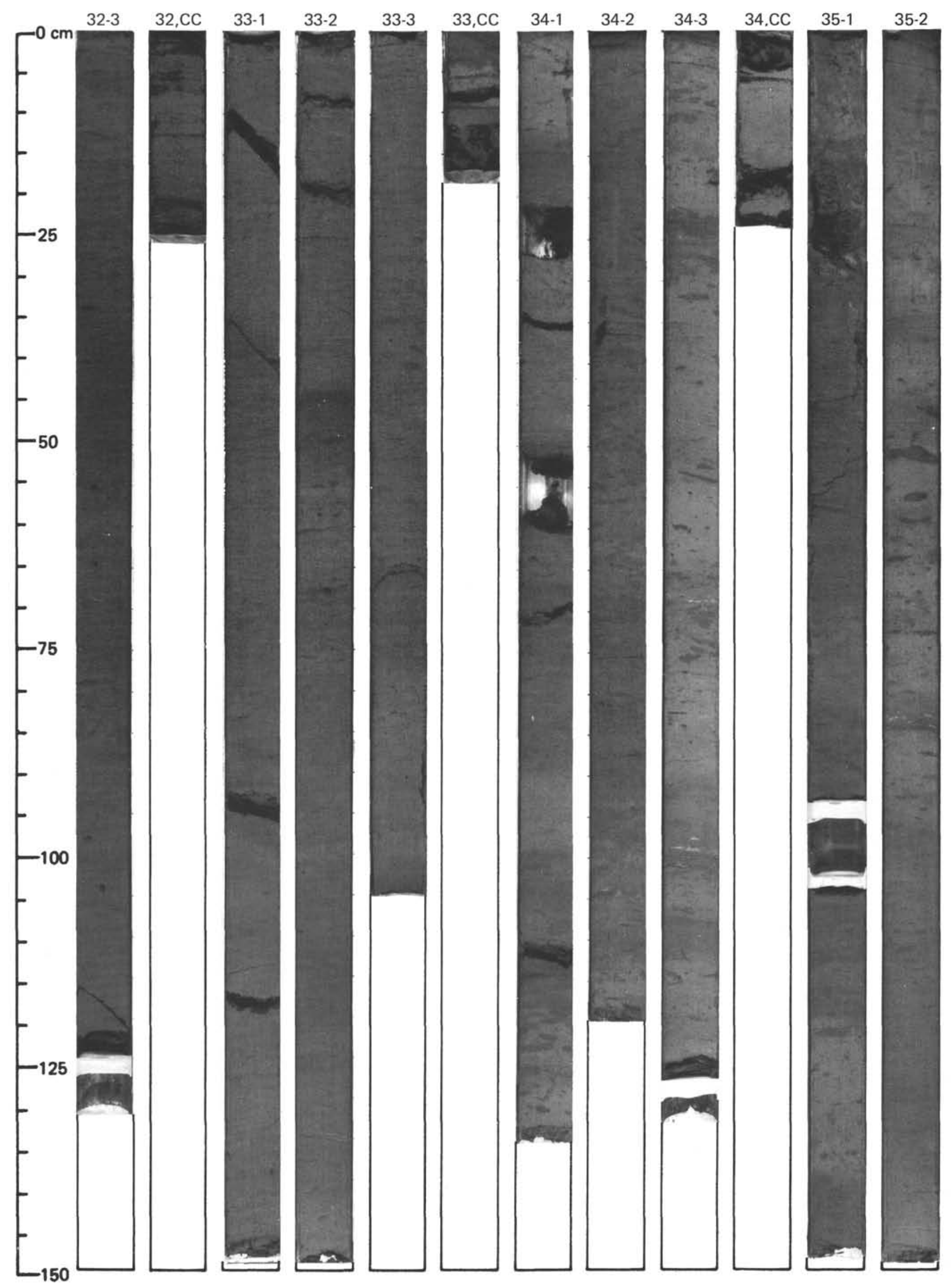


SITE 533 (HOLE 533)

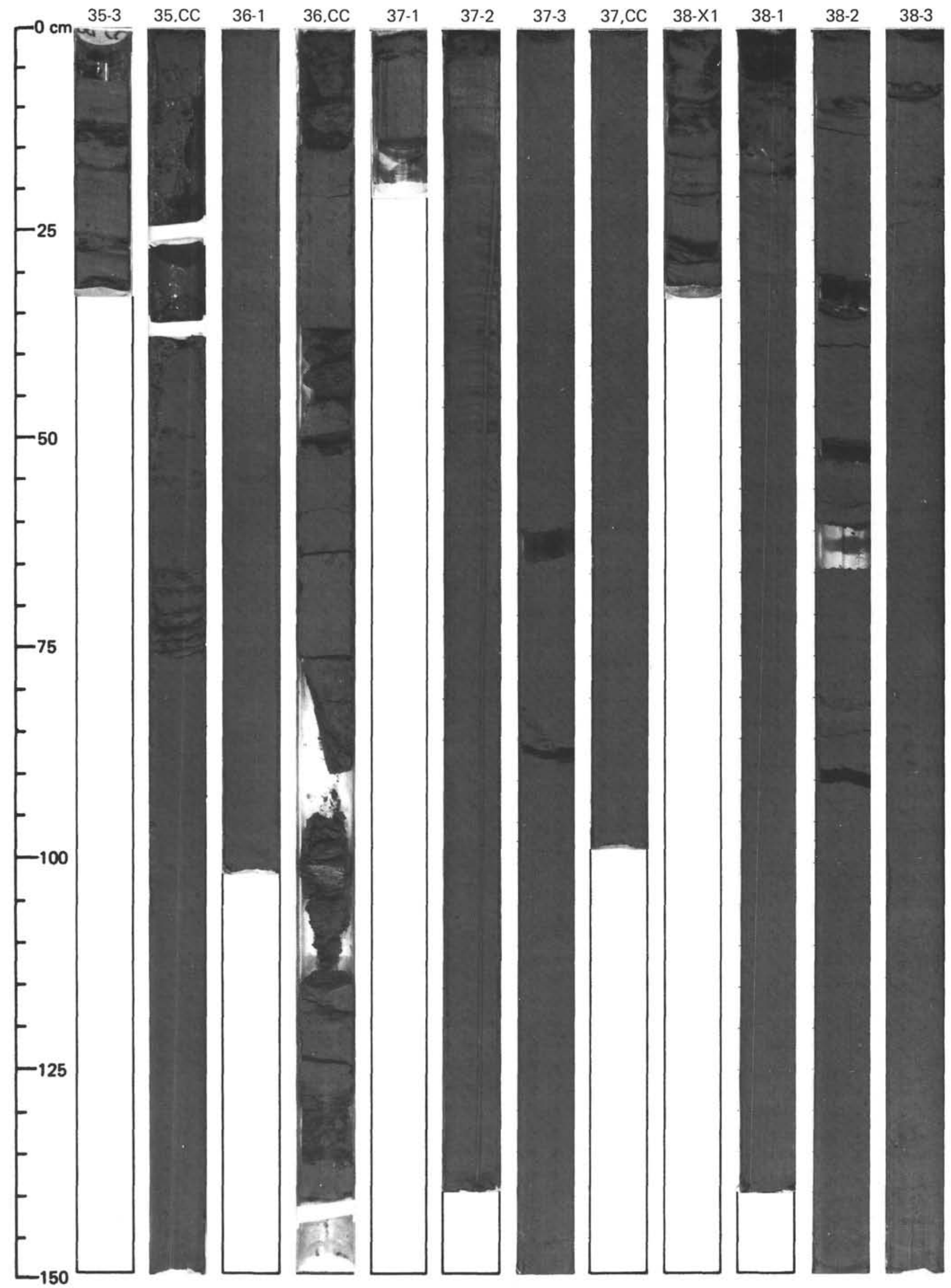




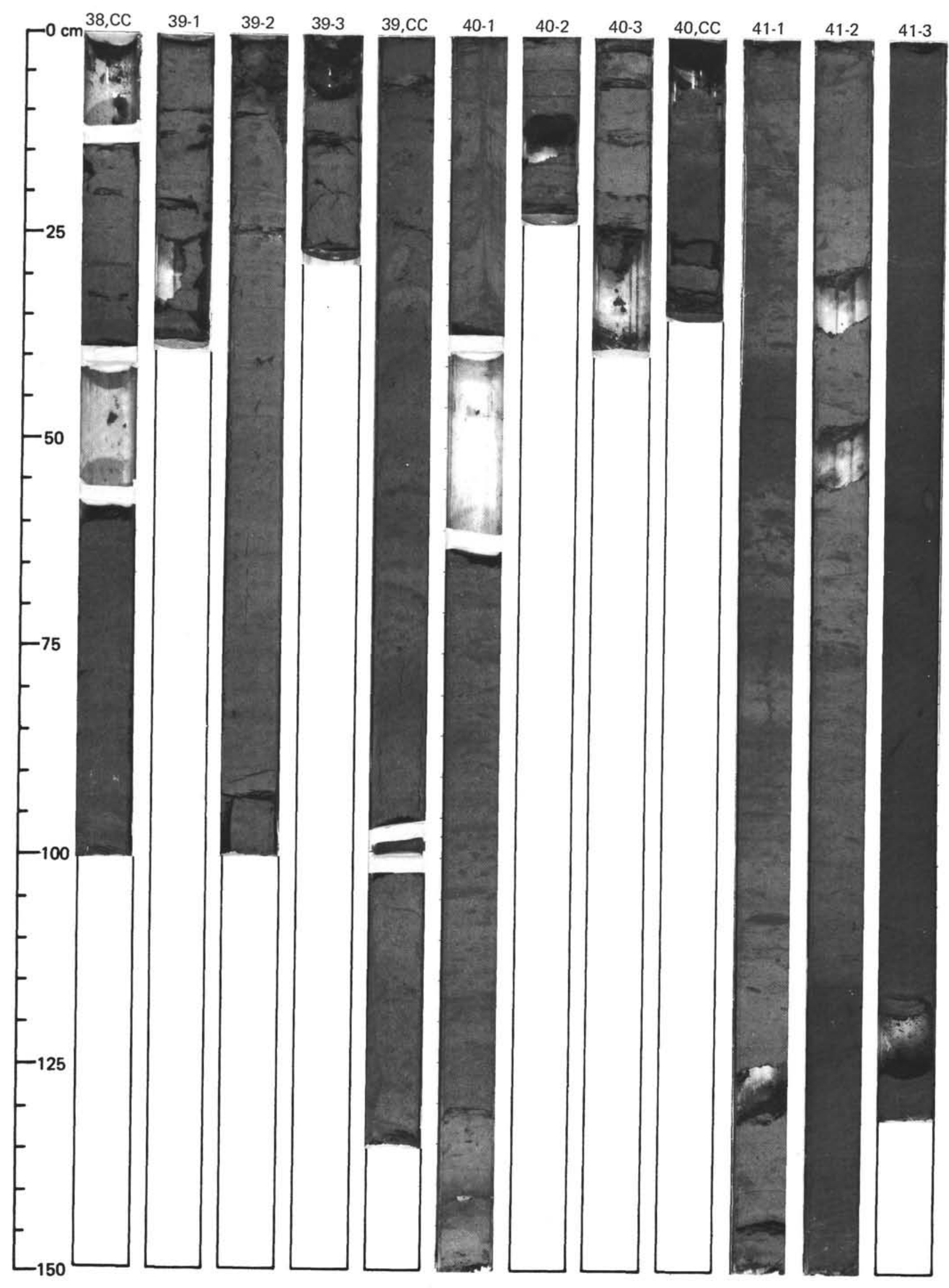




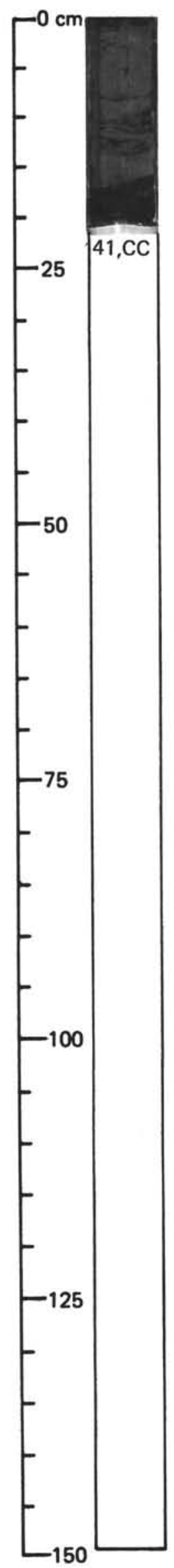




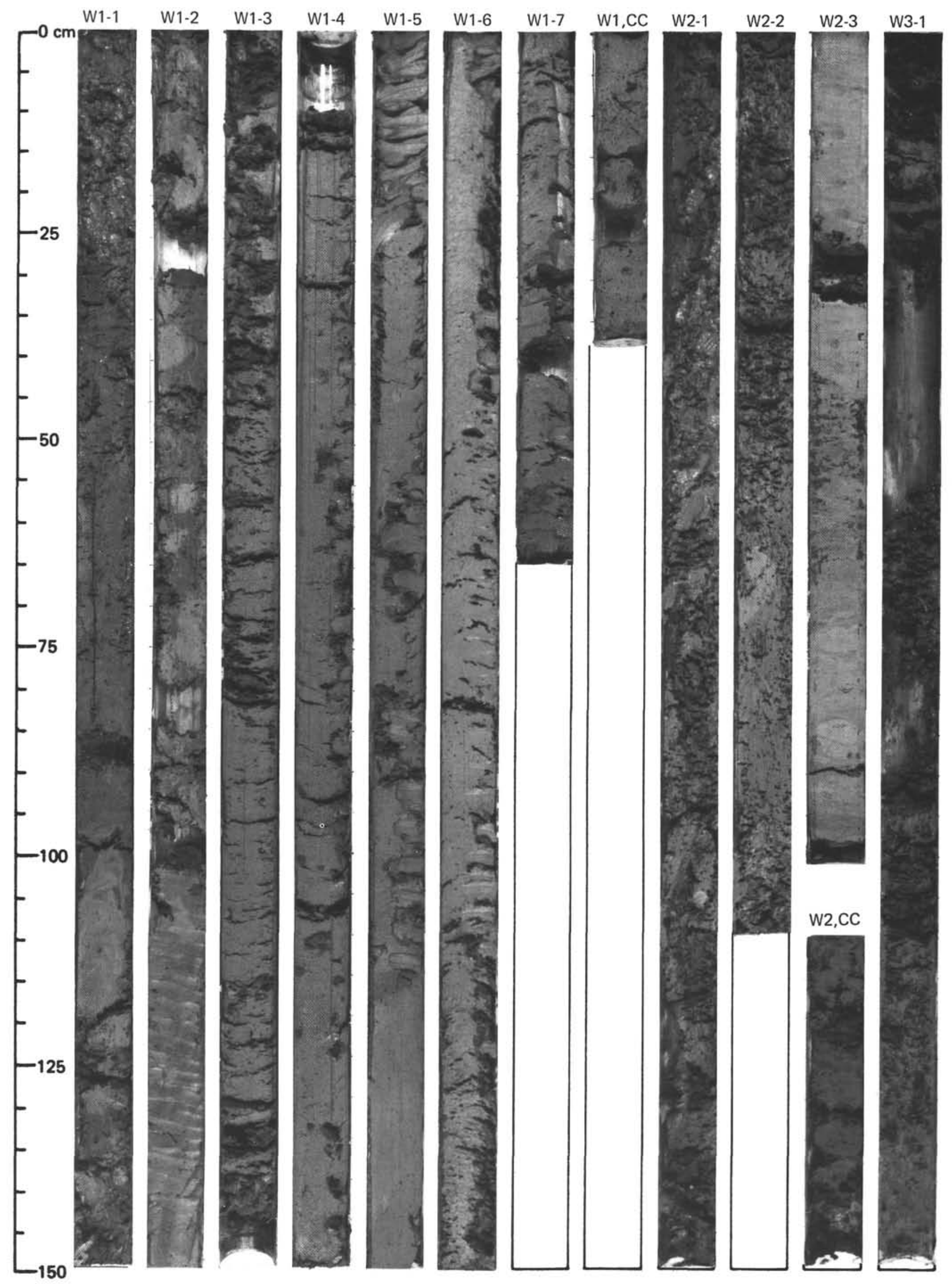




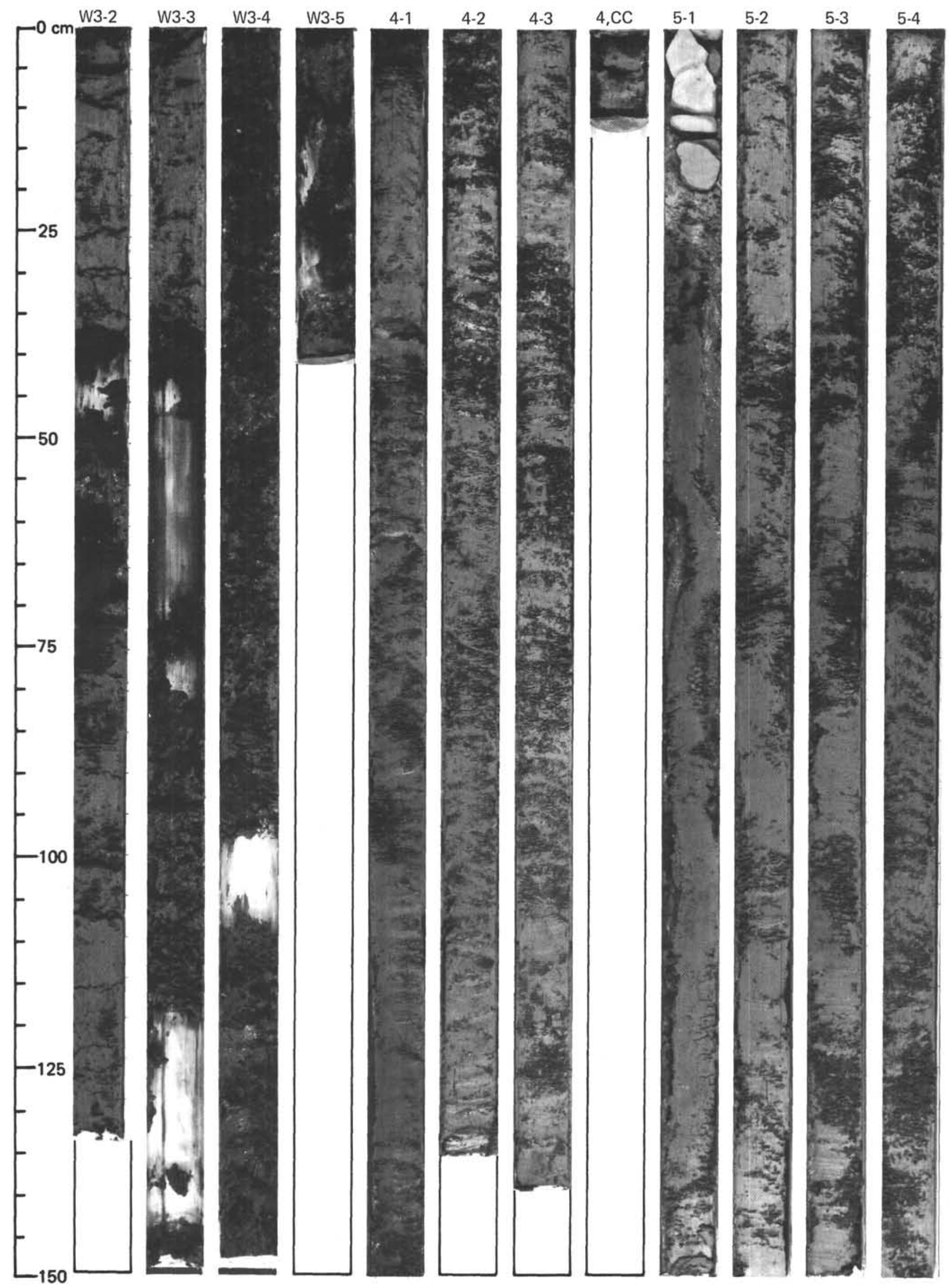


SITE 533 (HOLE 533A)

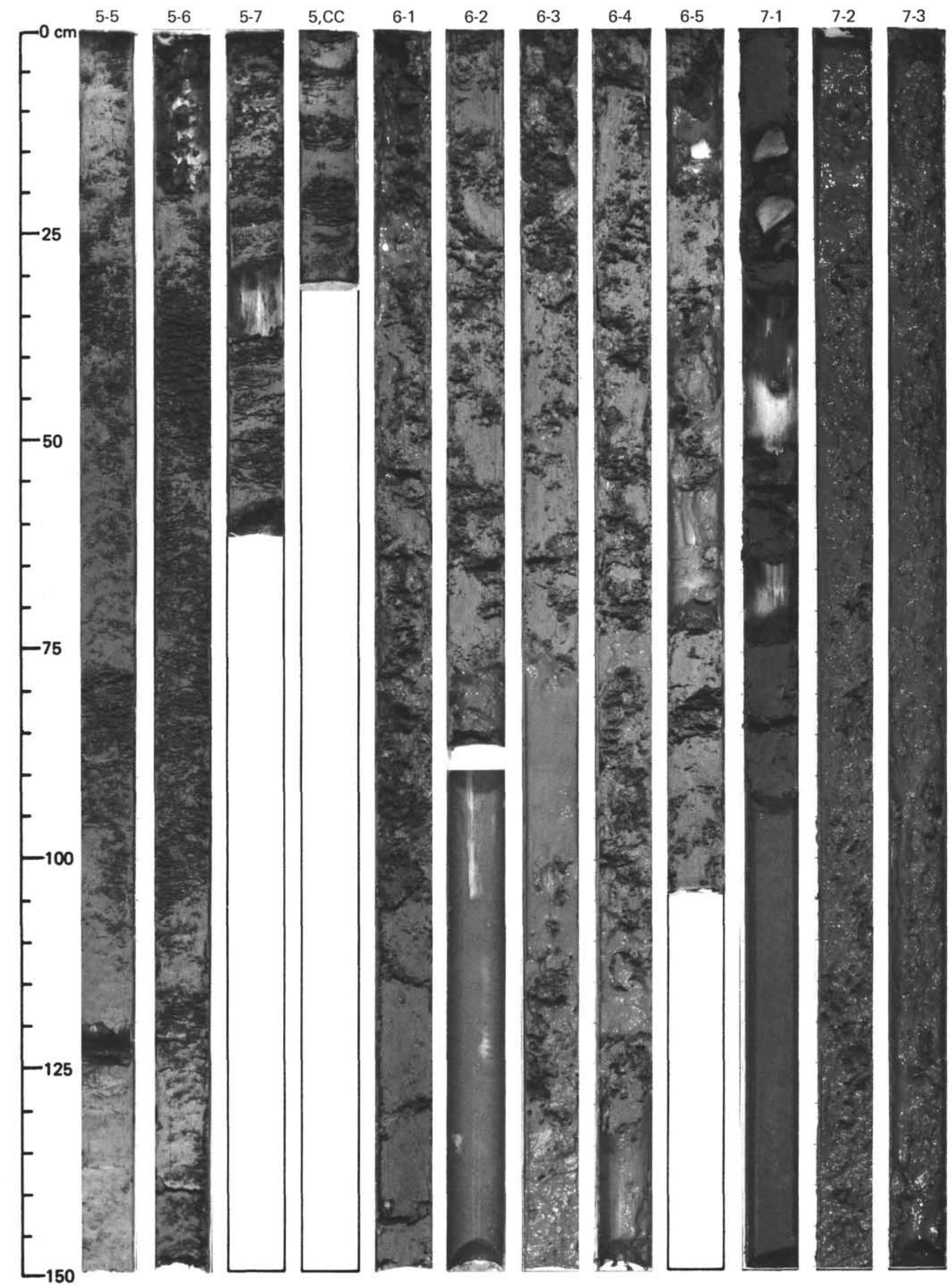


SITE 533 (HOLE 533A)

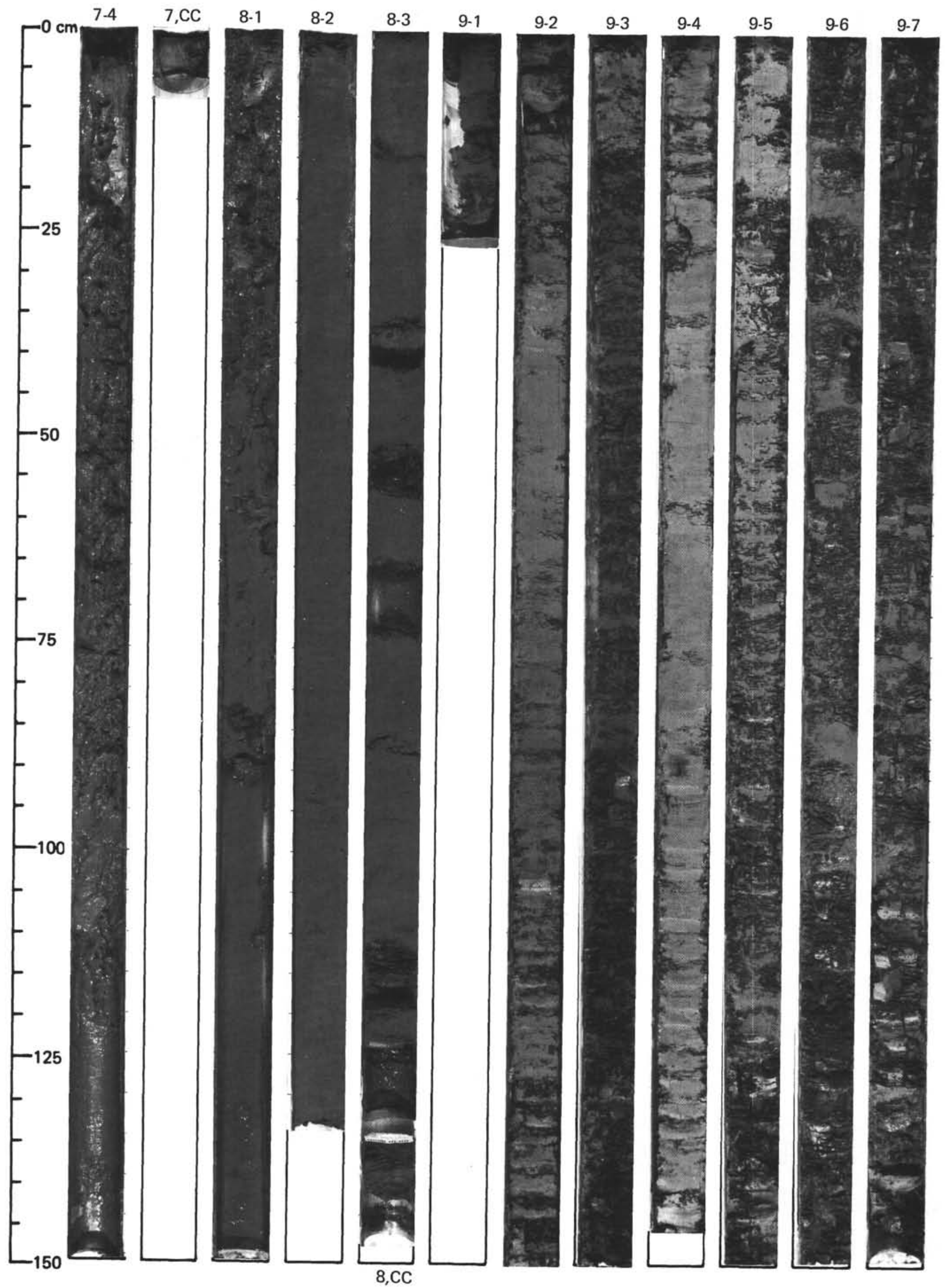




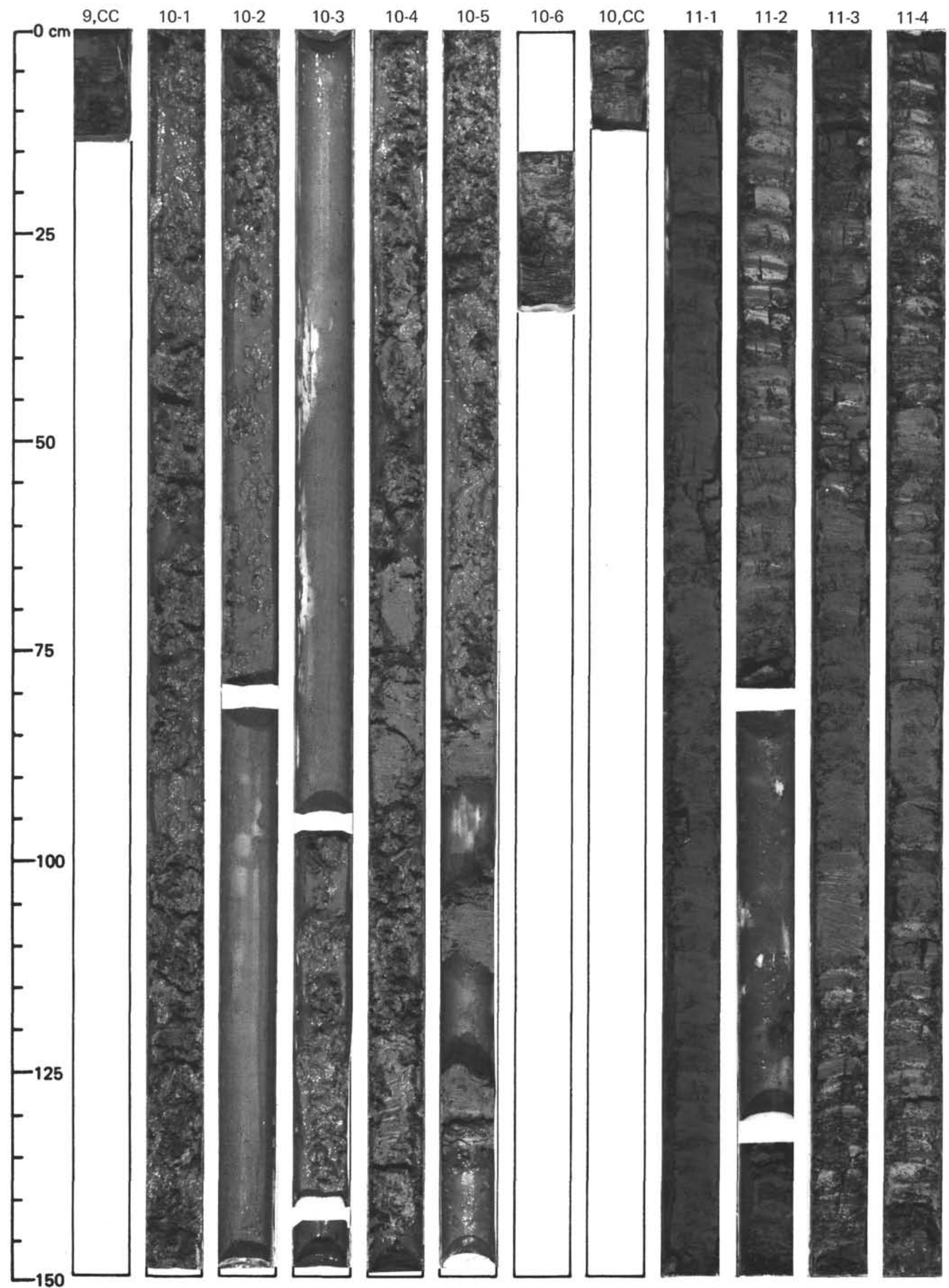




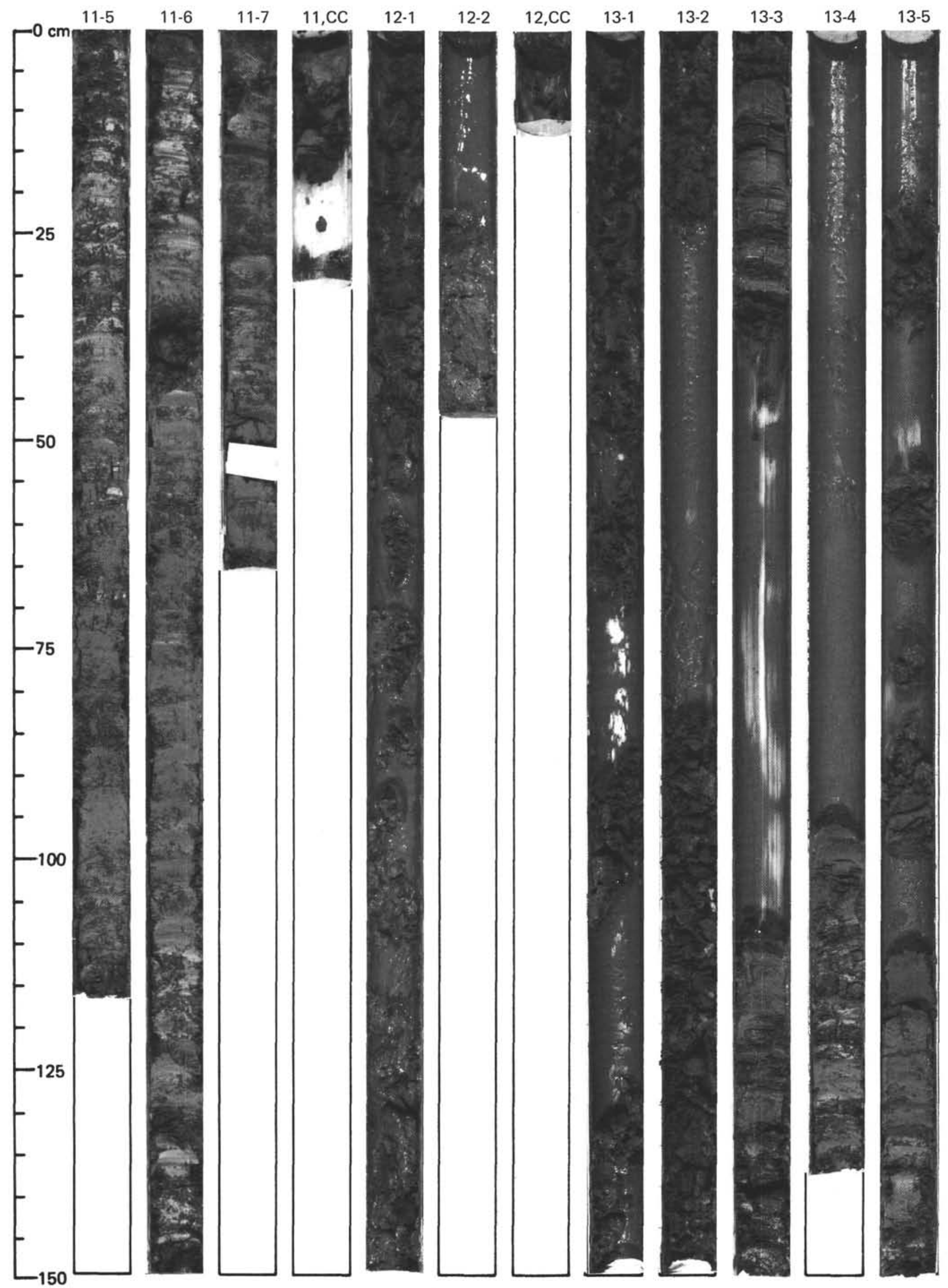




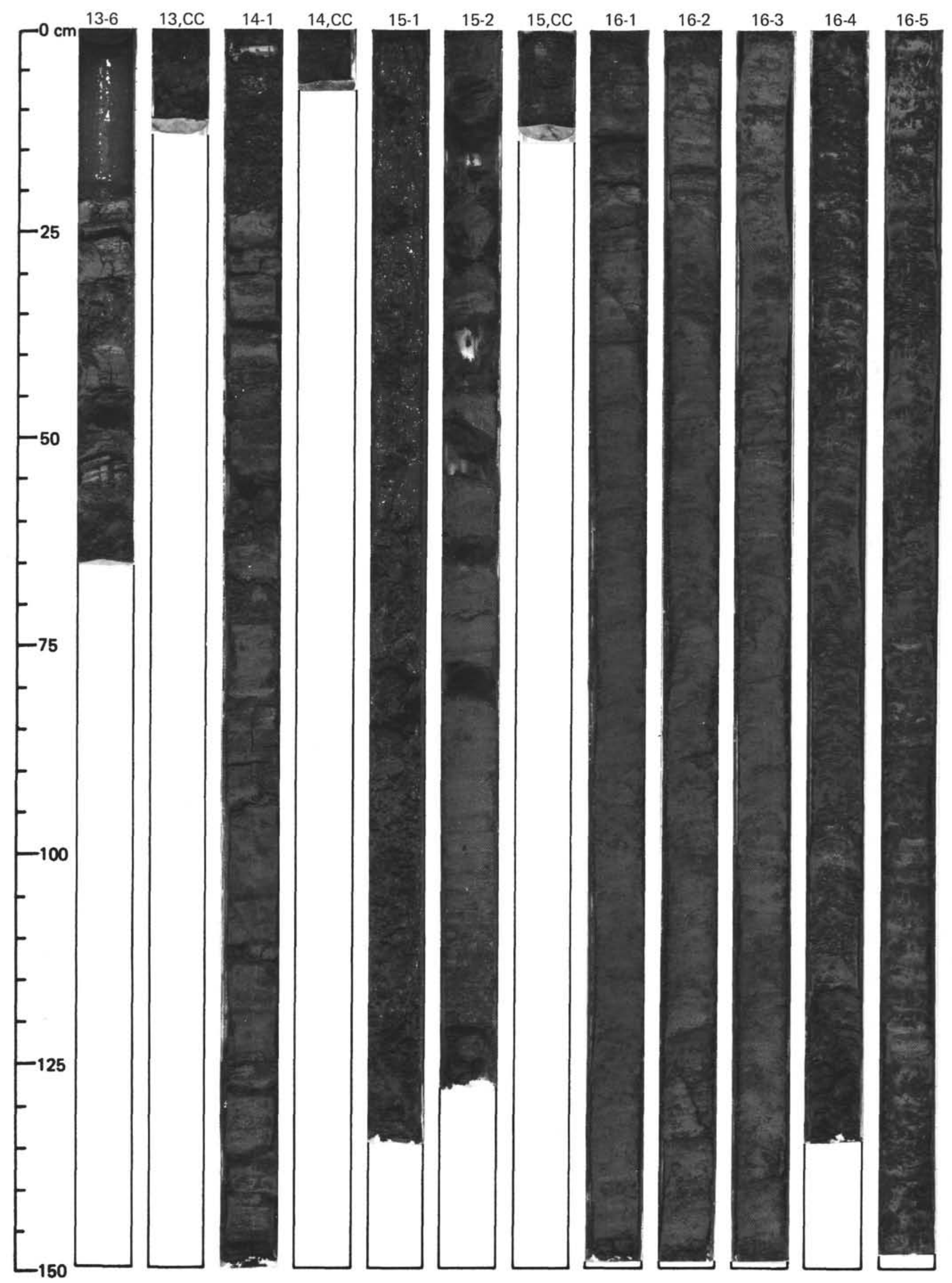


SITE 533 (HOLE 533A)

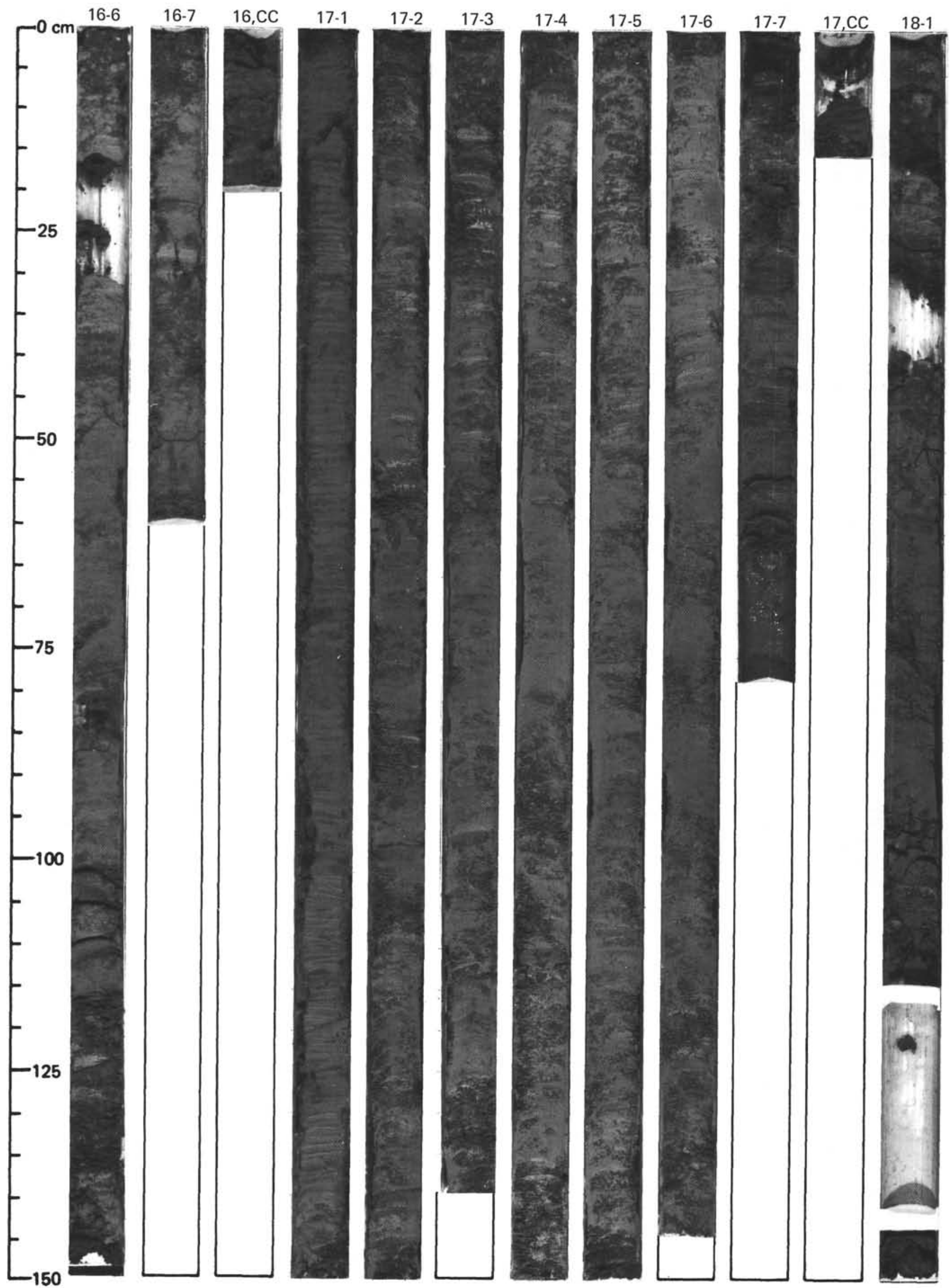




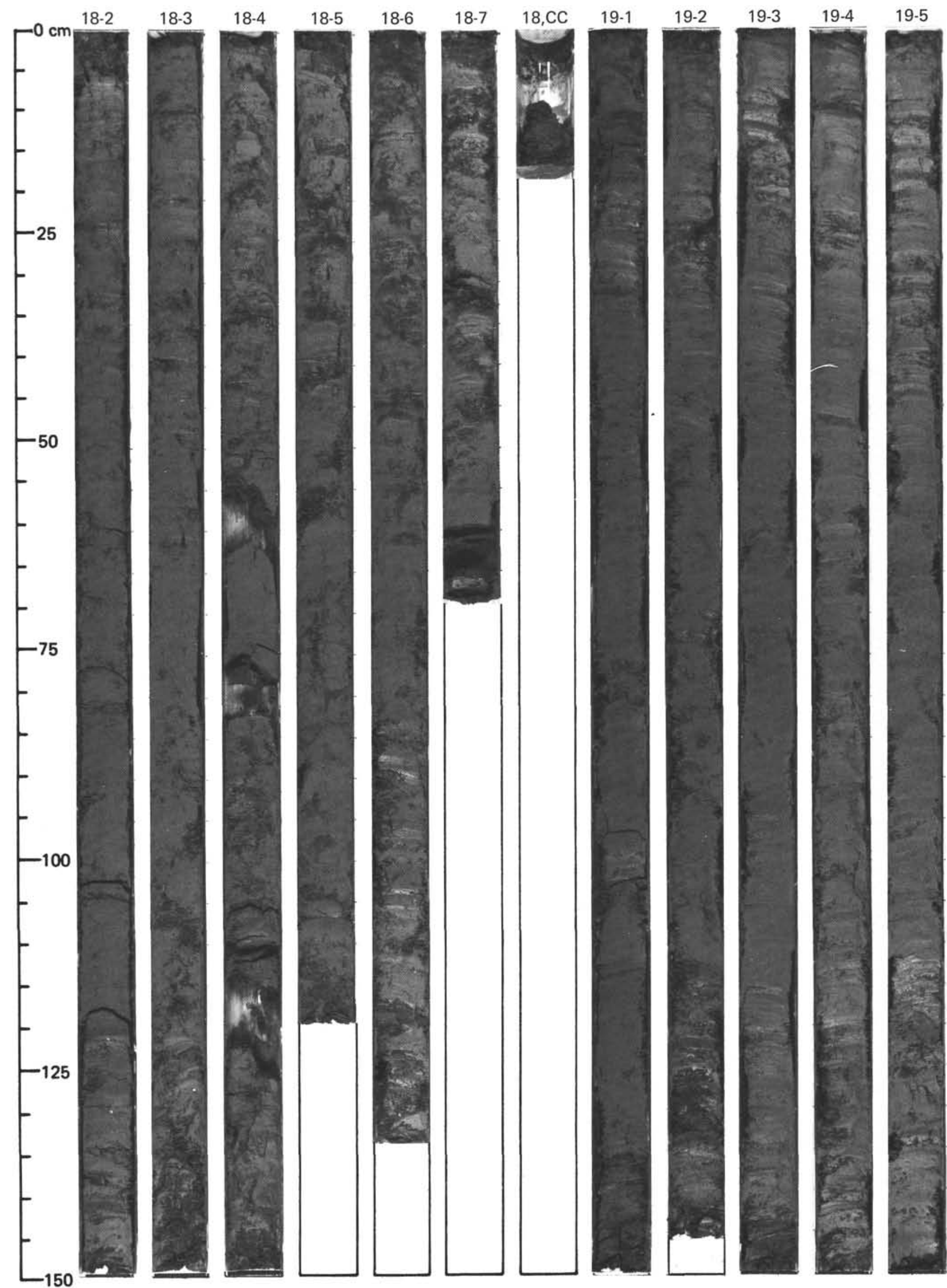


SITE 533 (HOLE 533A)

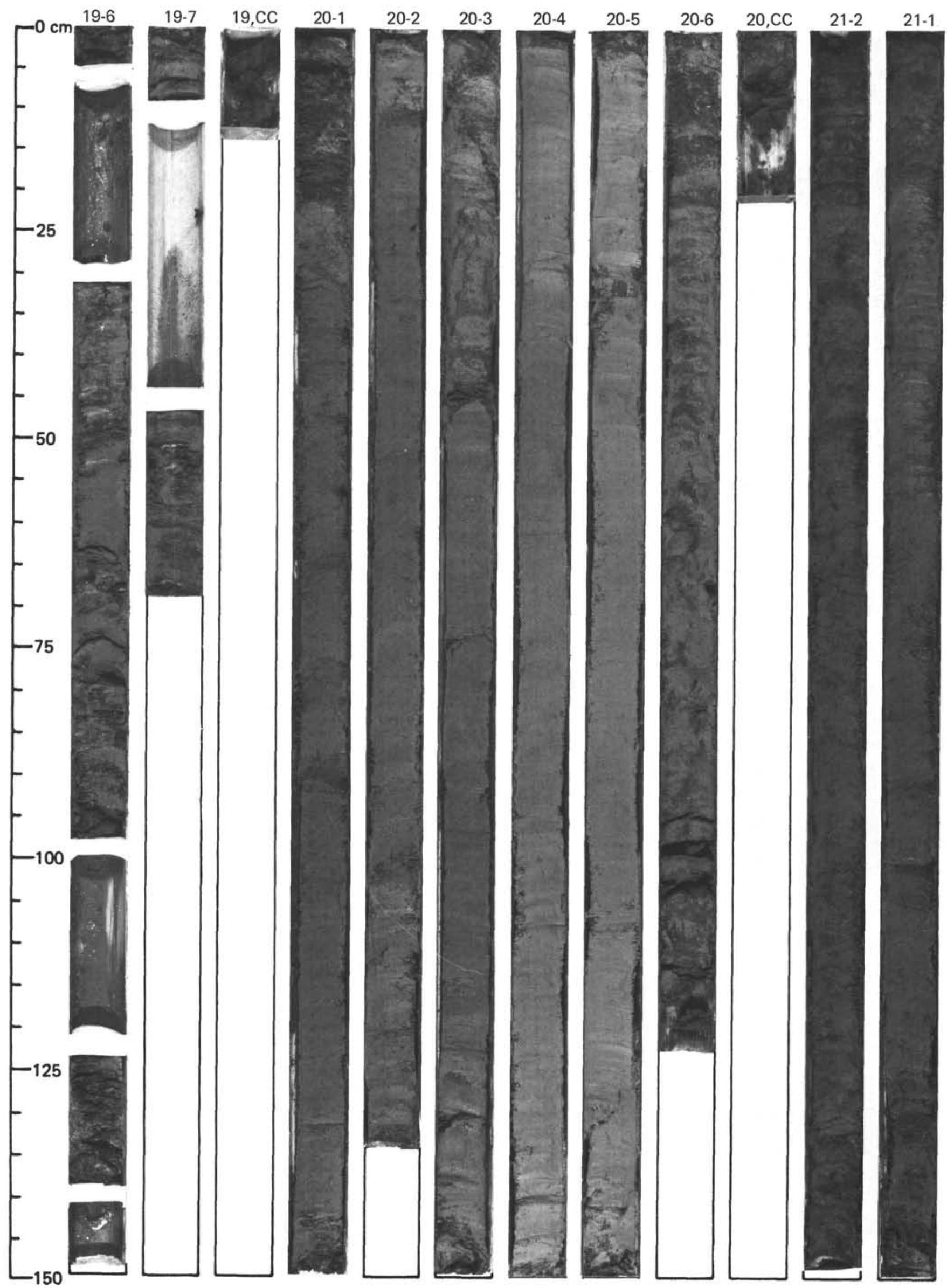


SITE 533 (HOLE 533A)

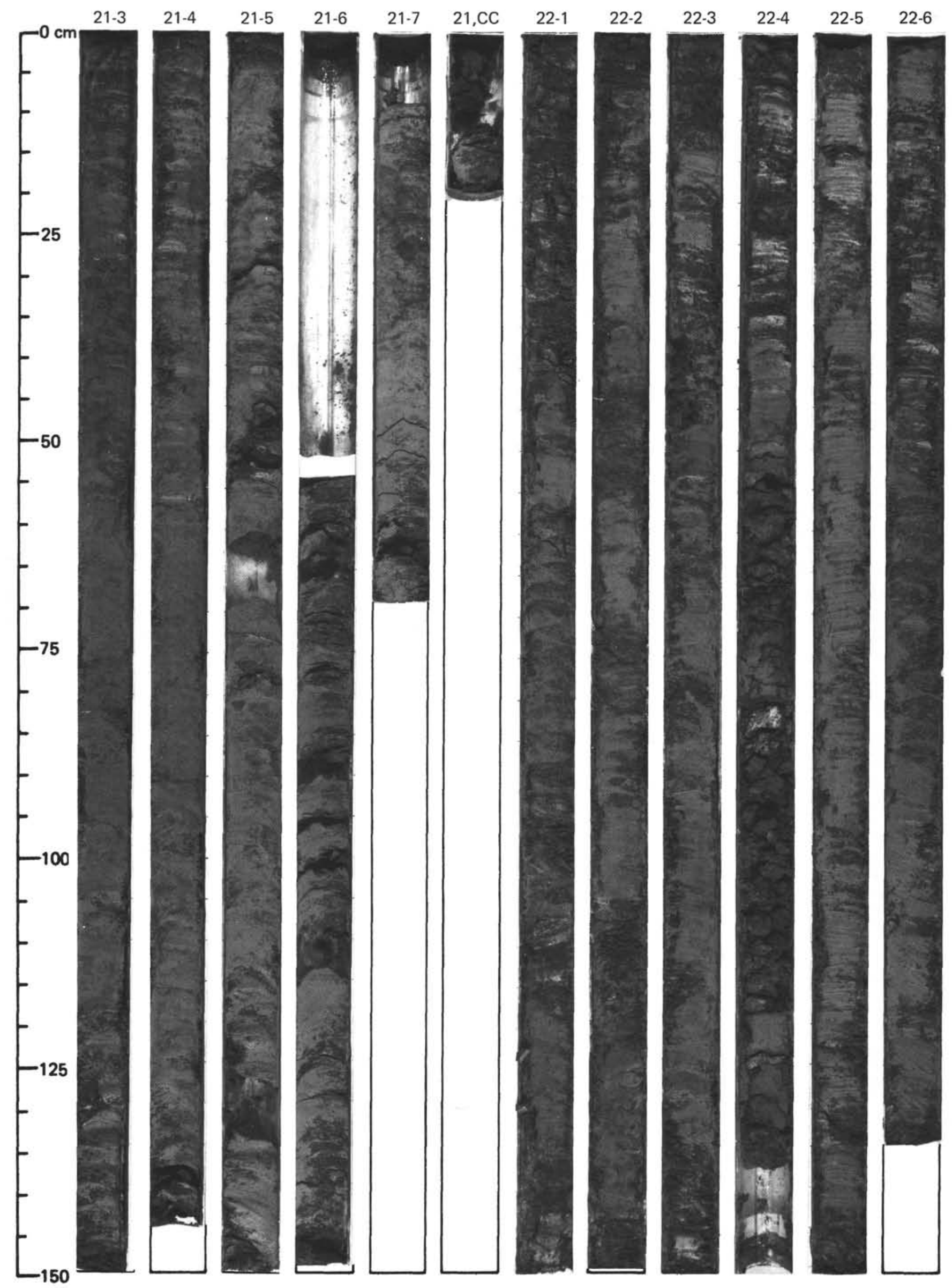


SITE 533 (HOLE 533A)

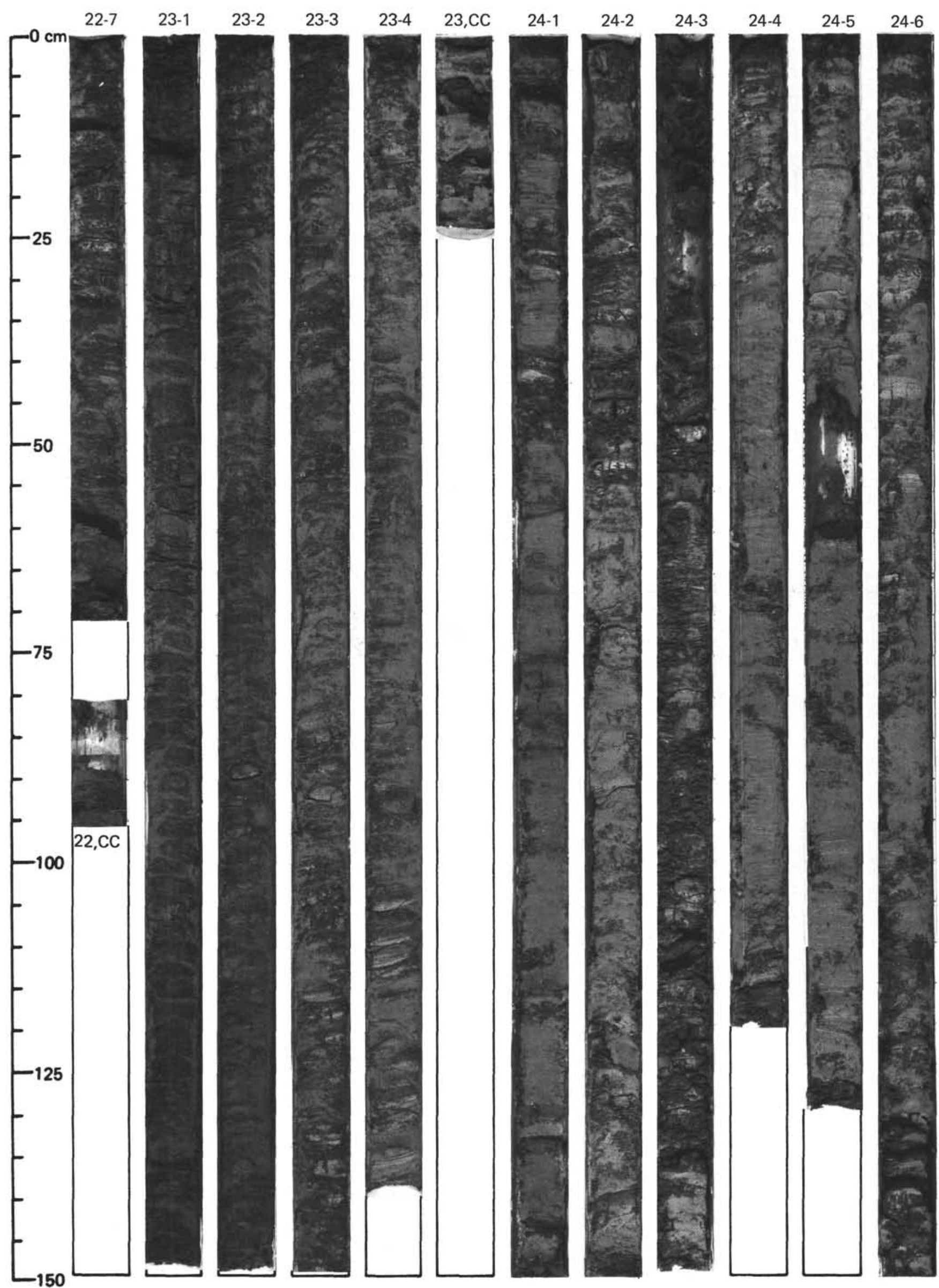




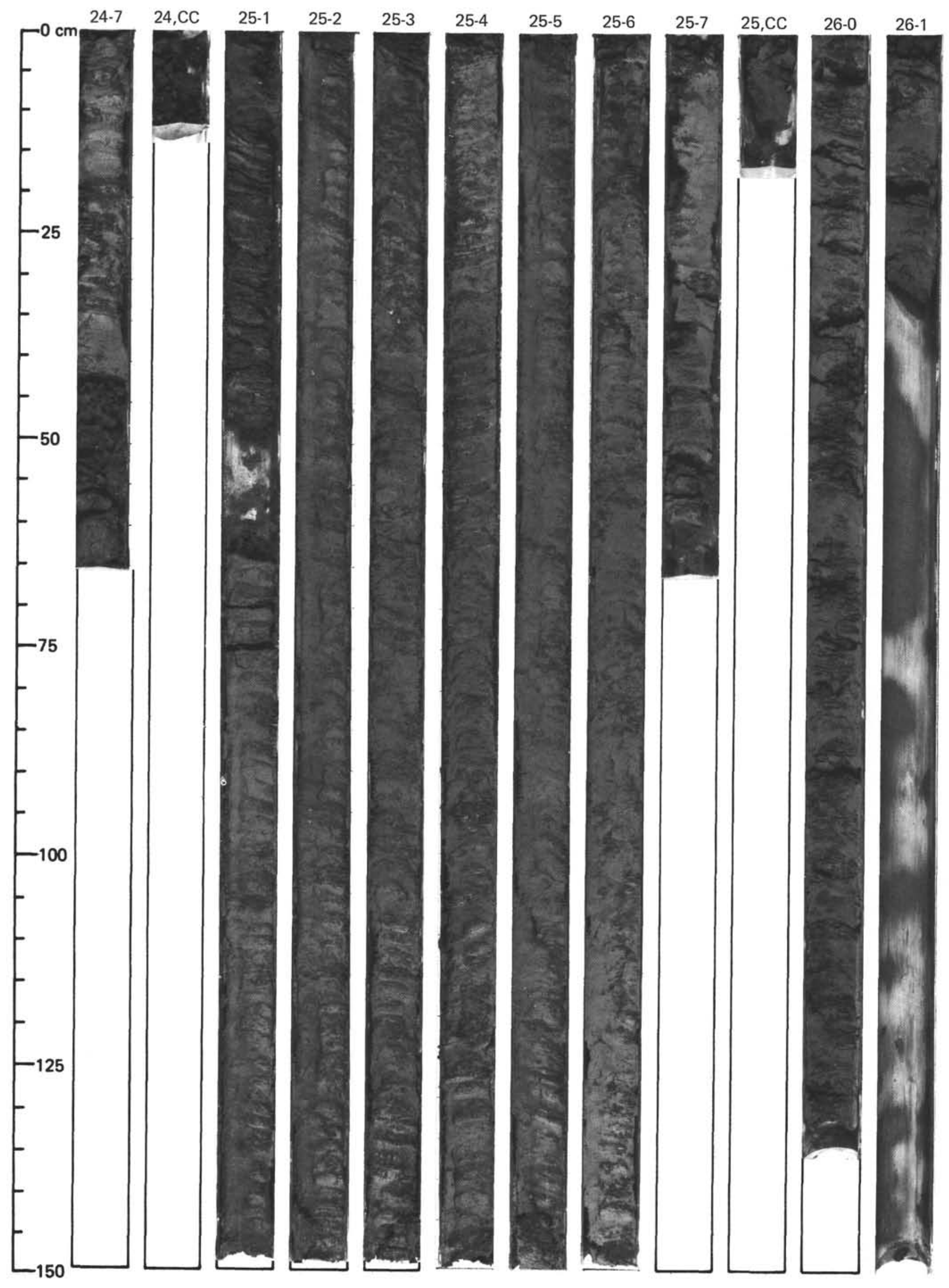


SITE 533 (HOLE 533A)

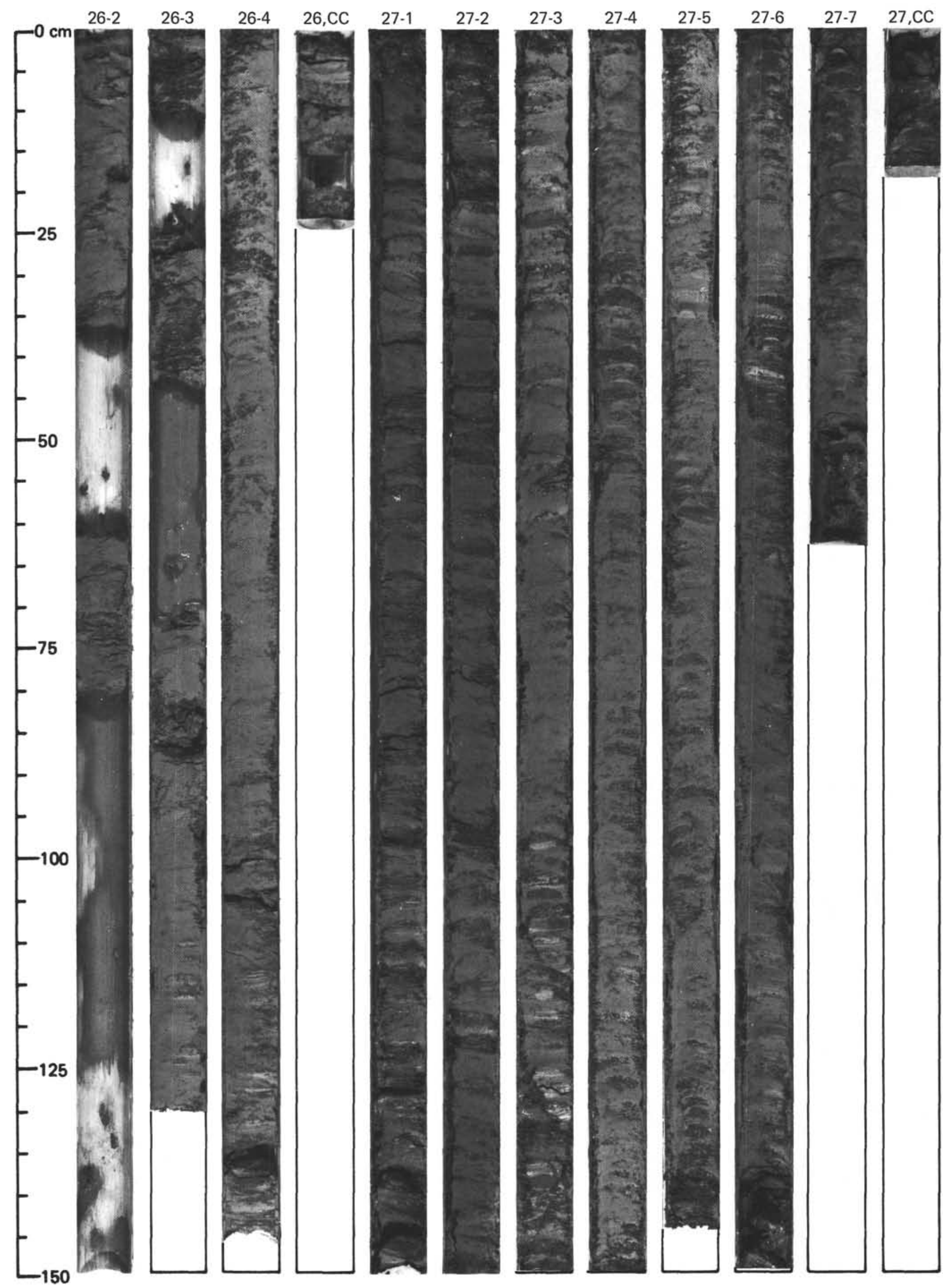


SITE 533 (HOLE 533A)

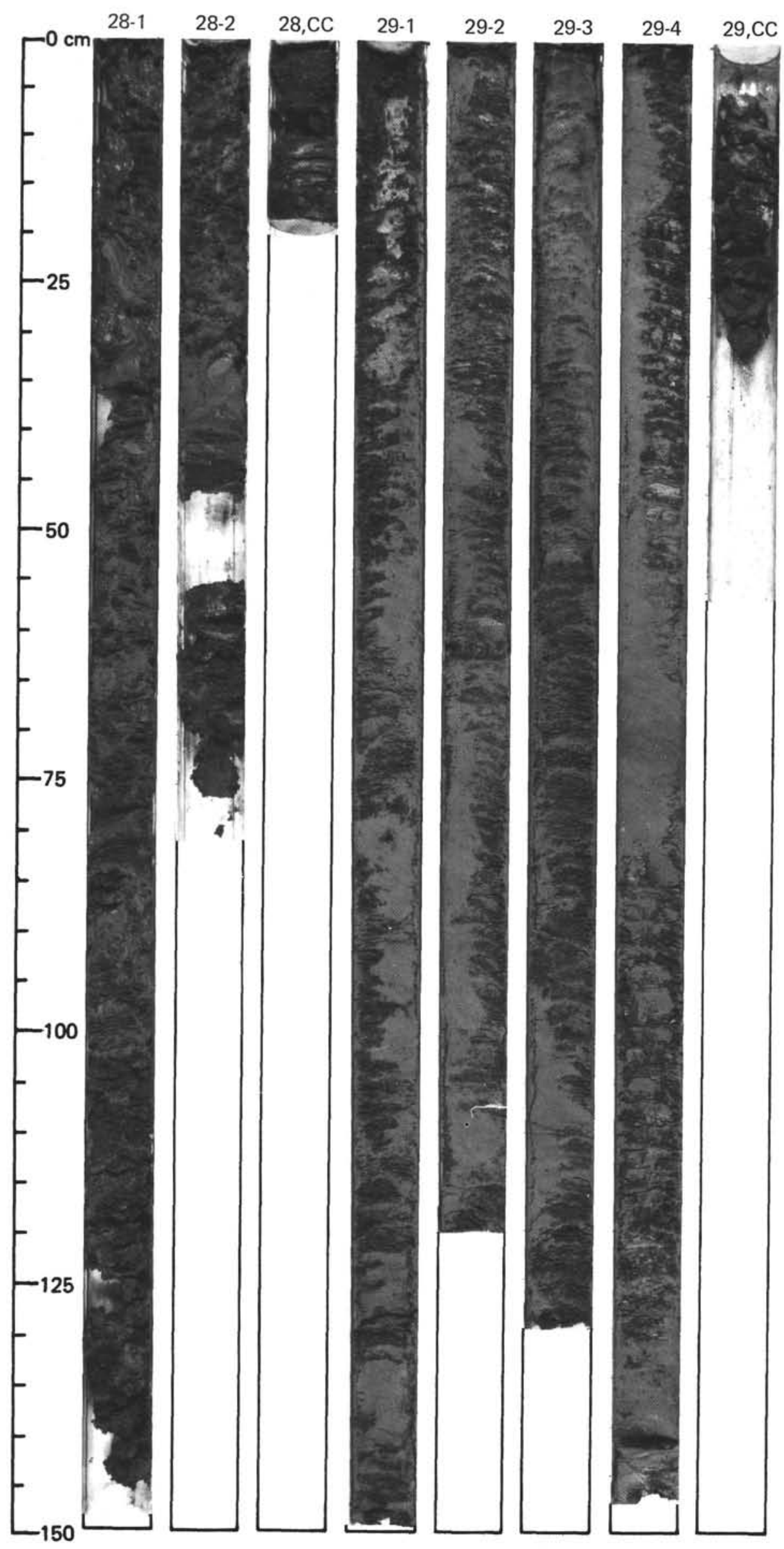

